

\title{
INVENTORY AND SOURCES OF TRANSURANIC SOLID WASTE
}

Submitled to:

LAWRENCE LIVERMORE LABORATORY

P.O. BOX 808, L-156

Livemrore. Callionla 94500

\author{
Atlention: \\ Dr. Herry Choung \\ Tosk Leoder
}

T: TERA ADVANCED SERVICES CORPORATION

2150 Shothuck Avenus

Berkeley, Califonla 94704

$415 \cdot 845 \cdot 5200$

August 1978

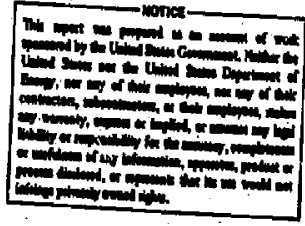




\section{TABE OF CONTENTS}

Section

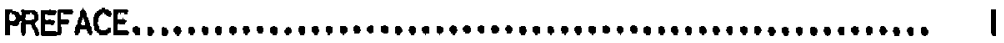

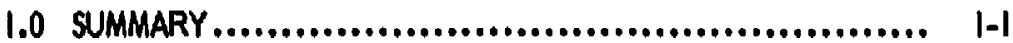

2.0 INTRODUCTION...................................... 2-1

2.1 Bockground on Tronsuranium (TRU) - Contaminated Waste .. 2-4

2.2 Tronsurenics (TRU) and Long-Lived Fission Product Wostes . 2-7

2.3 Management of Militory High-Level Woste.................. 2-8

2.4 Commercial Nuclear Industry ........................... 2-9

3.0 DEPARTMENT OF ENERGY (DOE) FACILITIES............... 3-1

3.1 Introduction ........................................ 3-1

3.2 Argome National Leboratory (ANL)....................... 3-3

3.3 Hanford Reserve ...................................... 3-3

3.4 Idaho National Engineering Laboratory (INEL)............... 3-4

3.5 Los Alamos Scientific Laboratory (LASL)................... 3-4

3.6 Mound Focility ........................................ 3-5

3.7 Odk Ridge Notional Laboratories (ORNL).................. 3-5

3.8 Rocky Flats Plont (RFP)............................... 3-6

3.9 Savornoh River Plant (SRP) .......................... 3-8

3.10 Other DOE Focilities ................................. 3-9

4.0 COMMERCIAL DISPOSAL SITES $\ldots \ldots \ldots \ldots \ldots \ldots \ldots \ldots \ldots \ldots \ldots$.....

4.1 Introduction .......................................... 4-1

4.2 Commercial Burial Practices.............................. 4-3

4.3 Criterio for Disposal or Storage..$\ldots \ldots \ldots \ldots \ldots \ldots \ldots \ldots \ldots$. . 4-8

5.0 COMMERCIAL NUCLEAR INDUSTRY...................... 5-1

5.1 Fuel Fobrication Industry............................. 5-1

5.2 Waste from the Spent Fuel Reprocessing Industry........... 5-6

5.3 Actinide Content ..................................... 5-19

5.4 Other Potential Sources................................ 5-20

6.0 TRU CONTAMINATED WASTE INYENTORY.................. 6-1

6.1 DOE Focilities ....................................... 6-1

6.2 Commercially Generated TRU Waste $\ldots . . \ldots \ldots \ldots \ldots \ldots \ldots \ldots .6$ 6-3

7.0 TRU.CONTAMINATED WASTE PROJECTIONS................ 7-1

7.1 DOE Woste Projections................................... 7-1

7.2 Commercial TRU-Contaminated Waste Projections........... 7-3

8.0 REFERENCES AND BIBLIOGRAPHY........................ 8-1 


\section{TABLE OF CONTENTS}

(CONT.)

Appendix $\quad$ Page

A Glossary and Metric to English Conversion Factors .............. A-I

B Honford Reservation ....................................... B-I

C Idoho National Engineering Laboratories (INEL) ................ C-I

D Savannah River Plont (SRP) ........................... D-I

E Other Department of Energy (DOE) Facilities ................. E-I

F Commercial Burial Sites ................................. F-I

G DOE Facility Survey Questionnaire and Results ............... G-I

H Potentiol TRU Waste Sourcess............................. H-I 


\section{PREFACE}

This report was prepared for Lowrence Livermore Labaratory (LLL) under LLL Purchase Order 9101903. This report provides an overview of the inventory and sources of tronsuranic (TRU) solid radioactive wastes. The information data base has been updoted through colendar year 1977 where possible. This dota base is being continually updated and will be revised by TERA Advanced Services Corporation os necessary during the duration of the LLL waste monogement progrom.

It is the purpose of this report to serve as a working document which will be used throughout the TRU waste management program. This report, and those following, will be compatible not only in format but also in content, reference material and direction. Comments, clerifications or improved data should be directed to B. G. Kniazewycz of TERA's Berkeley office. 


\subsection{SUMMARY}

In the early days of the Monharton Project, little thought was devoted to disposal of contaminated material since it was secondary to the main task at hand. Later, as it become epparent that the loboratories would become permanent federally supported activities, increasing attention wos given to waste disposal probiems, especially land burial. As the research, development and production progroms were expanded and modified, the waste motericls ond used equipment to be buried became much mare varied and more difficult to manage.

Solid radioactive waste had often been buried in the mast accessible and convenient vacont ploce, without a great deal of thought for the long-term consequences. Fortunotely, the amount of rodioctive material was not lorge at that time. The transuranium (TRU) elements were very strictly conserved and, at first, solid waste containing separated fission products was not a serious land burial problem. Wartime pressures for production and lack of knowledge or understanding led to siting and operational practices that, in many situations, are unsatisfactory by present day standords.

The purpose of the report is to support the development of standards and criterio which will specifically address the prablem of TRU contominated waste-generated by Department of Energy (DOE) nuclear programs and commercial application of nuclear technology.

Section 2.0 of this report presents on overview and introduction to the generation, sources and past practices dealing with TRU contaminated woste. In Section 3.0 the DOE focilities are discussed and supported in more detail in Appendices B through F. Section 4.0 and Appendix F address commercial disposal sites, while Section $\mathbf{5 . 0}$ oddresses the commercial muclear industry. The waste inventory is presented in Section 6.0, and waste projections are discussed in Section 7.0. Section 8.0 presents an extensive list of references and related bibliogrophy. 
Appendix A presents a glossary of terms and list of metric conversions. A DOE facility survey questionnire and results of that survey ore presented in Appendix G. Appendix $\mathrm{H}$ presents a list of potential TRU waste sources (special nuclear moterial licensees).

The generation of transuranicacontaminated waste moterial is associated with the light-water reactor fuel cycle if the spent fuel is recycled. In oddition, TRU wasie riny also be generated os a result of handling the spent fuel, either during interim storage $\alpha$ final repackaging and disposal. For the military TRU waste, i.e., those associated with the various national labs and facilities operated for the defense sector of the government, TRU material is generated as a rzsult of weopons program R\&D and production. In oddition, the use of nuclear power for noval ships will also generate such waste when the fuel is processed and recycled.

To odequately define the sources of TRU waste in the U.S. it is necessary to identify all present inventories of such wastes, as well as the focilities which generate or may generate such wastes in the future. In many cases, it is difficult to clearly define the TRU component generated at a focility without identifying the overall woste generation rates as well as charocteristics of the waste handled at each particular facility. Thus, this report identifies the overall waste management programs and generation rates at the various government focilities, along with the TRU components. This is especially important when other aspects of the LLi TRU woste manogement progrom are considered, In particular, the waste form and characteristics work requires that the various forms of TRU. contominated material be identified and quantified to such on extent that meaningful waste forms can be defined and technology to process this waste be identified.

TRU waste has been disposed of at five of the six commercial burial sites which have supported the commercial LWR industry os well as Deportment of Energy (DOE) *-generoted waste. The sites containing TRU waste are given in Table 6-4 of this report. These sites have acepted wastes generated in the fuel cycle;

* DOE and its predecessors AEC and ERDA. 
primarily fuel fabrication and spent-fuel reprocessing, as well as numerous miscellaneous R\&D octivities and small commercial uses of TRU racioisotopes. At present there is no commercial reprocessing of spent fuel and what high-level waste exists is limited to the nuclear fuel services at the West Valley Facility. The present inventory of TRU-contominated woste is limited primarily to DOEgenerated waste (shipments now terminated) and R\&D fuel fabrication activities involving plutonium. The best ovailoble information indicates that the cumulative DOE-generated TRU waste (through 1976) shipped to commercial burial grounds contained mout $7.6 \mathrm{~kg}$ of TRU isotopes. The cumulative TRU material buried through 1976 was $123.4 \mathrm{~kg}$ which is broken down by cornmercial burial site in Table 6-4.

The TRU solid woste itwentory that is locoted at seven different DOE sites is opproximately 0.41 million cubic meters. Only cout 10 percent of this is in retrievable storage.** By 1986 it is anticipoted that the retrievoble storoge inventory might increase by o foctor of 2.5 while the waste in burial sites remains virfually unchanged. The present TRU inventory of contaminated wastes, soils and sediment is as follows:

$\begin{array}{ll}\text { Retrievably stored } & 374 \mathrm{~kg} \text { TRU } \\ \text { Previously buried } & 760 \mathrm{~kg} \text { TRU } \\ \text { Contaminoted soils and sediments } & 190 \mathrm{~kg} \text { TRU }\end{array}$

* 0.37 million $\mathrm{m}^{3}$ are in land burial sites and 0.04 million $\mathrm{m}^{3}$ retrievably stored. 


\section{NIRODUCTION}

All operations that produce or use nuclear moterials generate rodioactive wastes. The wastes vary widely in volume, composition, and amount and type of radioactivity, depending on the materials and nature of the originating operations. Most of the radiooctive wastes generated today in the Uhited States are from Department of Energy (DOE) site operotions and from commercial nuclear reactors and supporting nuclear fuel cycle activities.

The radiocetive wastes are generally classified as either "high-level" wastes or "other" wostes. High-level wastes (HLW) are defined as those aqueous wastes resulting from the operation of the first cycle solvent extraction system, or equivalent, and the concentrated waste from subsequent extraction cycles, or equivalent, in a facility for reprocessing irradiated reactor fuels, ${ }^{66}$ during the initial step in the chemical reprocessing of spent fuel. Other waste classification schemes have been proposed and utilized. The classification of TRU waste will be the subject of a separate report. However, for the purpose of the present report the NRC classification scheme will be used.

The current NRC definition of Class A wastes is os follows: ${ }^{65}$

Closs $A$ radionctive wastes (CARW) are those rodioactive wastes which, due to their radiotoxicity and radioactive halflife, could reasonably be expected to contribute to radiation exposures in excess of those permitted by applicable Federal radiation standards through the use of state-of-the-art disposal methods other thon disposal in a Closs A radiociive waste repository.

From a literal reading, it would appear that no wastes are clossifiable as Class A radiocotive wastes, since state-of-the-art disposal methods eliminate radiation exposures that exceed those permitted by coplicable standards. However, it is understood that at issue here is the geologic isolation of certain classes $\mathrm{Ci}$ radioactive wastes, especially the high-level fission product wastes. Therefore, in this report all wastes that appear to have charocteristics that similarly justify geclogic isolation will be considered as potentiai Class A wastes. 
Pending numerical definitions currently under development by the NRC, the potential sources of Class A radioactive wastes are noted below. ${ }^{53}$

(I) Reprocessing of fuel discharged from light water power reactors:

- Solidified fission products and octinides from first-cycle raffinate in Purex extraction, referred to os high-level wostes.

- Fuelelement structural materials, including zircoloy cladding hulls, stainless steel components und fittings, and inconel spocers.

- Intermediate-level and low-level actinide (tronsuranic (TRU)) wastes from Purex reprocessing.

- $\mathrm{Kr}-85$ recovered from dissolver off-gos, as now required by EPA.

- I-129 recovered from dissolver off-gas, as now required by EPA.

- C-14 recovered from dissolver off-gas and from process ventilation. Although $\mathrm{C}-14$ recovery is not yet required, atmospheric releoses of $\mathrm{C}-14$ offer a greoter potential envizenpental hazard then do releases of $\mathrm{Kr}-85$ and $\mathrm{I}-$ 129.

- H-3 recovered from dischorge fuel. Although $\mathrm{H}_{-3}$ recovery is not yei required, recovery processes are being developed.

(2) Fabrication of mixed-oxide fuel: low-level transuranium (TRU) wastes are produced when reactor fuel is fabricated from uranium and recycled plutonium.

(3) Unreprocessed fuel discharged from light water power reactors.

(4) High-level rodioactive wostes and other wastes generated at the West Valley, N. Y. reprocessing plant. These wostes are exempted from 10 CFR 50 Appendix $F$ which requires that highlevel wastes from licensed fuel reprocessing plants be solidified and ultimotely transferred to a Federal repository. "However, these wastes are subject to a later rule-making decision, and if is logical that they be considered as potential Class $A$ viastes for a Fedaral repository. 
(5) Rodiogctive wastes from decommissioning reacters, independent spent-fuel storoge bosins, fyyl-reprocessing plants and mixed-oxide fuel-fabrication plants.

(6) High-level and transuranic radicactive wastes generated by the operation of the Desortment of Energy (DOE) facilities at Henford, Savornoh River, Rocky Flats, the Idaho National Engineering Laboratory and other: sites are referred to herein as "military wastes." Although no decision has been announced that these wostes are to be emplaced in a geologic isolation facility, the properties of these wastes are such that they should be considered os potential Class A wastes.

The source of the largest potential radiological hazard associated with wastes from the nuclear fuel cycle is the $H L W$ stream from fuel reprocessing, or the spent fuel assemblies in the absence of reprocessing (see Figure 2-1). A second category of solid wastes (See Figure 2-2), which ircludes a wide variety of materials such as cladding hulls ond iniscellaneous wastes from fuel reprocessing and refabrication steps, and which are referred to as transuranic (TRU) wostes, represents a problem comparable in impartance to that posed by isolation of the actinide component of the HLW. The viability of a nuclear energy industry depends upon the cbility to dispose of this moterial reliably and safely.

This report presents estimates of sources of tronsuranium solid wastes in the United States and an evaluation of the quantities of these wostes. It is assumed that transuranium solid waste has transuranium alpha radioactivity of greater than $10 \mathrm{nCi} / \mathrm{g}$ (nanocuries per gram). This assumption has the effect of excluding most of the very large volume of waste that is generated within the normally occupied work areas of transuranium processing and fobrication plants. It is assumed that wastes containing less thon $10 \mathrm{nCi} / \mathrm{g}$ of tronsuronium nuclides will continue to be buried on site cr shipped, generally as Low Specific Activity (LSA) or Type A Quentity material, to turial grounds (either commercial or DOE sites).

Up to the present time, commercially generated solid woste contaminated with transuranium (TRU) nuclides has been disposed of at commercial burial grounds. These ore sites carefully selected and monitored to provide reasonsble assurance that buried radioactivity is retained there: and is unlikely to migrate from the 
1

1

$\sqrt{11}$

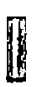

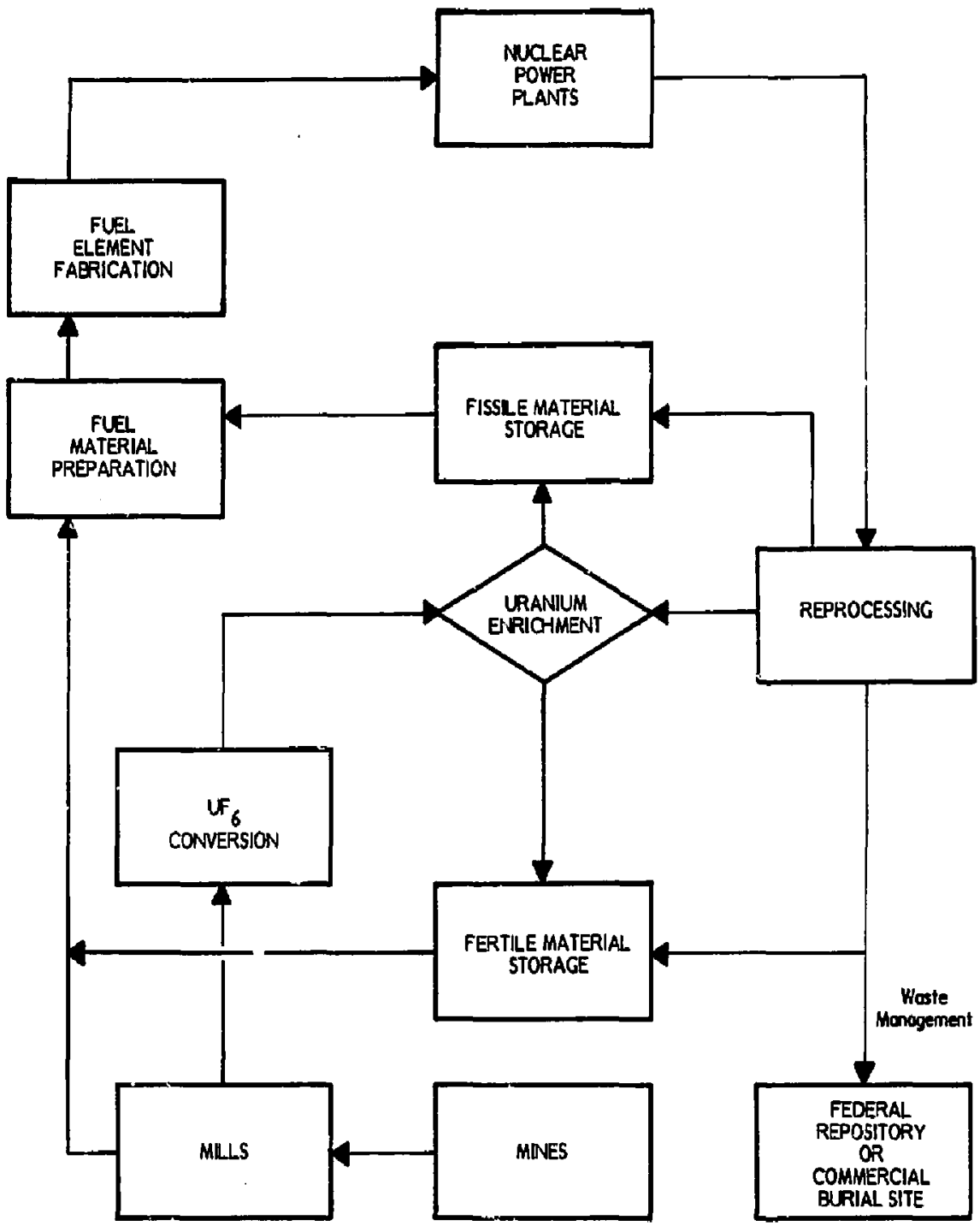

FIGURE 2-1

NUCLEAR FUEL CYCLE 


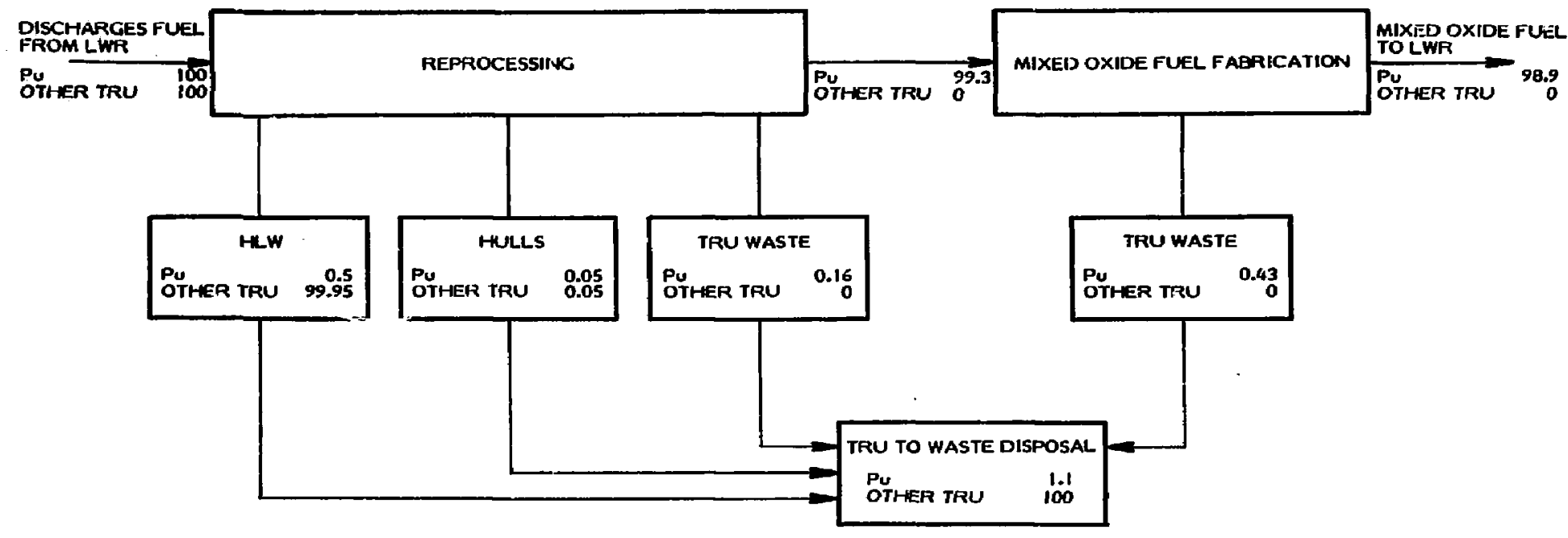

FIGURE 2-2

FATE OF TRANSURANICES IN LWR PLUTONIUM RECYCLE FLOWSHEET (NORMALIZED) ${ }^{70}$ 
vicinity. In these onalyses, no credit is given to containment provided by the packaging. There are six licensed burial grounds which hove operoted or confinue to operate and accept commercially generated low-level rodioactive waste and, at present, have TRU-contominated woste of levels below $10 \mathrm{nCi} / \mathrm{g}$. However, in the post four years some controversy has arisen concerning the probable migration of tronsuranic activity from the commercial burial site of Maxey Flats, Kentucky.

\subsection{BACKGROUND ON TRANSURANIUM (TRU) - CONTAMINATED WASTE}

Land burial has been used for the disposal of radioactive wastes since the inception of nuclear weapons research in the 1940's. The term "burial", as I Ad in this report, refers to the placement of waste at relatively shallow depths in earth materials, with no intent or provision for ready retrievability of a later date. As such, it is distinguished from geologic disposal and storoge techniques by the proximity of the waste to the surface of the earth and the surrounding biosphere. The migration or dispersal of the radioactive and other toxic materials in the waste must be kept to some minimum or acceptable level.

Initially, burial grounds operated by the U.S. Atomic Energy Commission (AEC) handled and disposed of wastes generated by AEC facilities as well as wastes from private industry. However, during the 1950's much of the waste generated within private industry was delivered to several private companies for sea disposal. Growing pressures against this technique coused the AEC to encourage the use of burial facilities at the Ook Ridge National Laboratory at Ook Ridge, Tennessee, and the National Recctor Testing Station in Idaho Folls, Idoho, until private burial grounds could be estoblished. In 1962 a commercial burial ground was opened af Beatty, Nevada, and in 1963 a similar site wos opened at Morehead, Kentucky. In May 1:63 the AEC discontinued its policy of accepting wastes from private industry. By 1971, six commercial sites were licensed for the handling and disposal of radioactive waste. 
At present, radioactive wastes in all categories other than "high-level waste" (produced during the first stoge of fuel reprocessing) are buried at both DOE and commercial burial sites.

In 1969 a controversy arose concerning the sofety of the burial activities involving plutonium contaminated soil at the then National Reactor Testing Station (NRTS) near Idaho Falls, Idaho (since renamed the Idaho National Engineering Laboratory (INEL)). The controversy primarily involved the concern for Pu-239 (o long half-life material) and its high toxicity per unit weight. As a result of this concern and the concern of Idaho officials over the long-term status of the aquifer beneath the project, the AEC mode a commitment that the waste in question would be directed or tronsferred to a Federal repository in salt (then being planned) when it became available. It is noted thut a U.S. Public Health Service review of the waste manogement practices in question led to the conclusion that the land burial techniques then in use met the Federal Rodiation Council criteria for protection of the public, and that it was very unlikely that the radiocctivity would migrate from the burial grounds in the future if the then current proctices were continued.

A commitment was made in 1970 by the commissioners of the AEC that all future tronsuranium waste would be stored temporarily in a readily accessible monner so that it would remain retrievable for a minimum of 20 years. ${ }^{61}$ This policy has recently been taken by operators to mean surface storage on specially constructed concrete or asphalt pads or in underground vaults of waste cantaining more than 10 nonocuries of transuranium nuclides per gram of waste. Waste contaminated with transuranium nuclides buried below the surface in previous years may be exhumed in the future.

A bockground discussion and rationale for considering the special problems of managing tronsuranium waste follows. 
The letter of commitment written by Chairman Glenn T. Seaborg to Senator Frank T. Church of Idcho on June 9, 1970 was aimed solely at the National Reactor Testing Station. It stated, "... AEC plans to store not only currently generated alpha waste, but also to excovate, process and ship such wostes that are being temporarily stored at NRTS. A number of years will be required to complete the tronsfer of such waste from NRTS, which we hope to start 'vithin the decade." Since nearly the whole decade has passed and neither a method of finally processing such wastes, nor a site for final disposal have been identified, it does not seem likely that the decade will see the initiation of that very large and potentially costly project. That general decision, however, has now been accepted by some as a commitment, and has contributed to the dilemma of the operators of commercial land burial sites when they are presented with waste containing transuronium elements.

On September 12, 1974 the AEC (now the NRC) published an intention to modify its regulations so as to require all commercial sources of transuranium wastes to ship it to selected AEC (now DOE) sites for retrievoble storoge. "7I Should this regulation be issued, the contribution from the nuclear power field will add to the size of those woste storoge focilities at DOE sites, and most certainly it will extend the period of subsequent handling and treatment of low-level tronsuranium-contaminated waste well into the foreseeable future. Unless there cre suitable sites for the final disposal of such waste, a substantial increase in the amount of radioactive material would necessarily be placed at surface or near surface storoge at some yet undesignated DOE sites.

Notably with the management of transuranium waste, the overlap between present proctice and older proctices makes it difficult to clearly identify the problems. There is some concern bout the radiological health similarities of seepage pits and land burial sites, particularly with respect to migration of radiooctive elements in the soil. 
It is assumed that transuranium wastes that have excessive unit size or radiation level for receipt at the Federal repository will be stored or buried on-site in a potentially retrievable form separate from nontransuranium wastes. These types of trensuranium wastes are generated predominantly at DOE or commercial plants* for reprocessing spent fuel and, as generated, are primarily o hazard because of their fission product content.

\subsection{TRANSURANICS (TRU) AND LONG-LIVED FISSION PRODUCT WASTES}

TRU and some fission product wastes are especially significant becouse they have long half-lives and some are rather radiotoxic. Some transuranic rodionuclides exhibit both of these properties and are primarily produced by single or multiple neutron copture by U-238 in LWR fuel during the operation of a nuclear reactor. Reprocessing of spent fuel attempts to remove plutonium, but since the separation is not complete, the resulting high-activity liquids will contain some plutonium as well as other tronsuranics. Likewise, transuranic contamination of low-activity wastes aiso occurs when the transuranic materiols ore hondled or processed, which is primarily at DOE facilities involved in nuclear weopons production.

Tronsuranics are persistent in the environment, and as a general rule are strongly retained by soils. They are not easily transported through most food chains, although some reconcentration does take place in the oquatic food chain. They pose only a slight biological hazard to humans upon ingestion becouse they are weokly obsorbed from the gastrointestinal tract. A greoter hazard results froin

* Presently, no commercial reprocessing of spent fuel is allowed by the Federal government. 
inhalation since they behave like normal dust, and fractionate accordingly. Production of an adverse health effect in the lung, or elsewhere, depends on the particle size and solubility of the inhaled contaminated dust. Upon entry into the bloodstream (either by ingestion or inhelation), TRUs will then readily accumulate in bone and liver tissues, and cen significantly increase the risk of cancer. ${ }^{56}$

Prior to 1970 TRU-contaminated wastes were not segregated from other lowactivity wastes. Current DOE policy is to retrieve and store wastes containing greater thon 10 nanocuries of TRU alpha-emitting rodionuclides per gram. ${ }^{61,71}$ Transuranium-contaminated wastes being produced by private commercial activities, however, are still being buried at one (Richlond) of the six operating commerical burial grounds. Burial at the remaining five commercial sites is currently limited to those wastes containing less then 10 nanocuries of TRU alpha-emitting rodionuclides per gram.

\subsection{MANAGEMENT OF MILITARY HIGH-LEVEL WASTE}

During the early years of the Government's nuclear weopen program, little attention was devoted to developing technologies for lang-term storoge or disposal of high-level waste. Priorities were ploced on producing nucleor weapons materials; waste management decisions were based on short-term expediency rather than long-term implications. As a result, 270 million liters of high-level defense waste are "temporarily" stored in field turks at the DOE Honford Works and Sovannoh River Plant. ${ }^{12,15,24}$ Additionally, 11.4 million liters are stored at Idaho National Engineering Laboratory (INEL). 2I The waste stored at Hanford and Sovarnach River make up chout 94 percent of the total volume of DOE woste.

Most high-level waste from reprocessing operations is produced in an acidic chemical form. Stainless steel must be used for temporary storage tanks for acid waste. In the early years of the Government's nuclear weupons program, however, stainless steel was scarce and expensive, so the AEC decided to neutralize the waste produced at Hanford to allow storage in tanks constructed 
from cheoper and more readily ovailable carbon steel. Tanks des:gned at the Savannah River facilities, constructed in the early 1950's, were modeled after the Hanford facilities, incorporating improvements from Hanford operating experience. As a result, acidic waste to Savarnah River is also neutralized before storage in carbon steel tanks. Numerous disadvantages to surh neutralization are evident. These include the fact that injecting the neutralizing agent more than doubles the volume of high-level waste which must be stored and eventually disposed of. Further, plutonium and $\mathrm{Sr}-90$ are insoluble in neutralized waste and eventually settle in a sludge at the bottom of the storage tanks. Removing the sludge from storage tanks is a very difficult technological problem. Further, while the technology necessary to convert this neutralized waste to a suitable form for long-term storoge or disposal has been demonstrated on the loboratory scale, o full scale operation is still questionable.

Section 3.0 discusses DOE focilities and is supplemented by more detailed information in Appendices $B$ through $E$.

\subsection{COMMERCIAL NUCLEAR INDUSTRY}

Solid wastes containing smoll amounts of alpha radioactivity are routinely produced during normal commercial operations at nuclear fuel fabrication and spent fuel reprocessing plants. Although these wastes ordinarily have a very low actinide content, their heterogeneous nature, combined with the very long-lived alpha content, may impose a safety hazard for mary decades. To properly assess the magnitude of the alpha waste disposal problem, it is necessary to characterize the nature and quantities of wastes produced to date and, to the extent possible, to predict future waste production rates from the commercial nuciear industry operations. Detailed discussion is provided in Section 5.0.

\subsection{FUEL FABRICATION INDUSTRY}

The fuel fahrication industry includes both the plutonium fuel preparation plants and fuel fobrication plents. 
The function of the plutonium fuel preparation plants is to prepare mixed $\mathrm{UO}_{2}$ $\mathrm{PuO}_{2}$ thot is used to fobricate fuel elements for plutonium-fueled light water

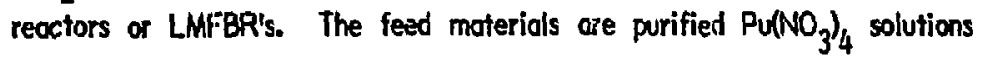
received from spent fuel processing plants and natural or depleted uronium as $\mathrm{UO}_{3}, \mathrm{UO}_{2}$, or $\mathrm{UO}_{2}\left(\mathrm{NO}_{3}\right)_{2}$ solutions.

These plants will probably be physically located on the same site as a fabrication or spent fuel processing plont but, in either cose, the plant will generate a characteristic low radiation level, transuranium waste. The fuel fabrication plont will fabricate mixed $\mathrm{UO}_{2}-\mathrm{PuO}_{2}$ fuel for either light water reactors or the LMFBR. This plont generates a low radiation TRU waste of which 60-80 percent by volume is combustible and subject to incineration or other means of volume reduction. 59

Most of the wastes are generated inside glove boxes, but a significant amount of waste is also generated externol to the boxes in contamination control meosures. In larger scale facilities, wastes contaminated with recoverable amounts of actinides are separated from the wastes that are candidates for burial. The most common burial vessel is the standard 208-liter steel drum (DOT 17C or 17H). Plutonium-contaminated wastes have been usually buried off-site, by a disposal contractor, in coproved commercial burial sites. Uranium contaminated wastes are buried of approved commercial sites.

\subsubsection{SPENT FUEL REPROCESSING INDUSTRY}

Solid wastes from reprocessing plants con be classified into five categories: clodding hulls, intermediate- and low-level (ILW/LLW), general trash, failed equipment and dry chemicals. The volume of cladding hulls, ILW/LLW and dry chemical wostes are proportional to the amount of spent fuel reprocessed, while the volurres of generol trash and failed equipment are opproximately independent of plants throughout and are produced at opproximately a constant annual rate per plant. 
Of the total volume of solid waste produced in the reprocessing irdustry, about 70 percent of the volume will originate from general trash, while the other 30 percent will be coout equally divided among the ofher four categories. The distribution of the plutonium in the woste will remain foirly constant through the years of 32 percent in the cladding hulls, 42 percent in the ILL/LLW, 21 percent in the general trash, four percent in the dry chemicals and less then one percent in the foiled equipment. 59

Most of the low radiation level, transuranium solid waste generated in a spent fuel processing plant originates in the sections of the plant that are used for final purification, storoge, and shipping of the plutonium product.

\subsubsection{OTHER SOURCES}

Radionuclides used in the proctice of nuclear medicine constitute the largest fraction of the non-fuel cycle uses of radioactivity. Other rodioisotopes are finding extensive cpplications in well-logging, in industrial radiography, as largecurie teletheropy and irradiator sources, in some consumer products (such as smoke detectors), and in the manufacture of certain types of gauges. These, together with relatively small amounts of radioactive material used in research, constitute the primary opplications of rodioisotopes and potential waste sources. $^{48}$

Other TRU waste is possibly generated due to industrial and medical application

of tronsurcmic radioisotopes. Such uses will generate miniscule levels of waste compered to DOE and nuclear fuel cycle wastes. 


\section{DEPARTMENT OF EERG DOEFACUTIES}

The purpose of this section is to provide a brief overview of the major DOE focilities. More extensive information is provided in Appendices B through E.

\subsection{INTRODUCTION}

DOE contractors operate large land burial operations of five principal DOE facilities. Oak Ridge Nationol Loboratory (ORNL), Ook Ridge, Tennessee; Los Alomos Scientific Loboratory (LASL), Los Alomos, New Mexico; Idaho National Engineering Loooratory (INEL), Idoho Falls, Idaho; Hanford Works, Richland, Woshington and Sovonnah River Piant (SRP), Aiken, South Corolina. Smaller land burial sites are of other DOE focilities including Sondia, Albuquerque, New Mexico; Pantex, Amarillo, Texas; Nevada Test Site, Las Vegas, Nevada; Feed Materials Production Center, Fernald, Ohio; and the gosecus diffusion plants at Oak Ridge, Tennessee, Paducah, Kentucky, and Portsmouth, Ohio. A list of mojor DOE waste generoting/burial sites is given in Table 3-1.

In 1970 AEC (DOE) established a policy that transuranic waste in concentrations exceeding 10 nanocuries per gram be stored coove ground and be retrievable. ${ }^{3}$ At the five principal facilities an estimated one million cubic meters of waste have been buried containing 18 million curies. The waste includes approximately 952 kilograms of transuranium nuclides; mainly at INEL and Hanford, of which 740 kilograms are buried and 212 kilograms are retrievably stared (1975). The current annual volume of DOE generated waste is approximately $65,000 \mathrm{~m}^{3}$. The volume is expected to decrease grodually in the fufure with the use of improved woste management techniques including volume reduction technology. "I

DOE facilities at Oak Ridge, Los Alamos, Sovannah River, Idaho and Hanford, have also used cribs for disposal of some liquid waste which contained levels of radioactivity unocceptable for release to uncontrolled areas. Through 1974 over 525 billion liters of liquid waste, containing five million curies, have been discharged into the ground at Sovanch River, Idaho and Hanford with the intention that the radioactivity would be tracked as it moved through the soil beyond the point of release and that the extent of migration would be limited by removing the driving force of further liquid releases." 
Amarillo, Texas - DOE generating site; DOE storage and disposal site, (uraniumcontaminated waste, and tronsuranic-contaminated waste).

Argonne, lllinois - DOE generating site.

Fernald, Ohio - DOE generating site, DOE disfosal and storage site (uraniumcontaminated waste).

Henford, Woshington - DOE generating site; DOE storage and disposal site (fission product/induced activity coniaminated waste, uranium-contaminated waste, tronsuranic - contaminated waste).

Idaho Falls, Idaho -- DOE generating site; DOE storage and disposal site (fission product/induced activity-contamincited waste, uranium-contaminated waste, and transuranic-contaminated waste).

Livermare, California - DOE waste generating site; DOE storage and disposal site (uronium- and thor rum-contaminated waste).

Los Alamos, New Mexico - DOE generating site; DOE storage and disposol site (fission product/indjyced activity-contaminated waste, uranium-contaminated waste, and transuranic-contaminated waste).

Miamisburg, Ohio - DOE generating site.

Las Vegos, Nevada - DOE generating site; DOE storage and disposal sites (fission product/induced activity-contaminated waste, tronsuranic-contaminated waste).

Paducah, Kentucky - DOE generating site; DOE storage and disposal site (uranium-contaminated wastel.

Piketon, Ohio - DOE generating site, DOE disposal and storage site (uraniumcontaminated waste).

Oak Ridge, Tennessee - DOE generating site; DOE storage and disposal site (fission product/inchuced octivity-contaminated waste, uranium-contaminated waste, and transuranic-contamineied wastel.

Rocky Flats, Colorado - DOE generating site.

Albuquerque, New Mexico - DOE generating site; DOE storage and disposal site, (uronium-contaminated waste, and transuranic-contaminated woste).

Aiken, South Carolina - DOE generating site; DOE storage and disposal site (uranium-contominated waste, fission product/induced activity-contaninated waste, and transuranic-contaminated waste). 


\subsection{ARGONNE NATIONAL LABORATORY (ANL)}

There is no active buriol ground at ANL but at the time of decommissioning of the original laboratory in the city of Chicago, building rubble was buried in the Cook County Forest Reserve. The site is known and kept under surveillence. Other ANL-generated wastes and building rubble were also buried at this lacation. ANL produces a wide variety of solid radioactive wastes suitable for burial. Some solid waste arises from the treatment of liquid waste streoms by evaporotion of the liquid waste to a high solids content and a dense self-solidification with vermiculite in 208-liter drums. The total amual solid waste produced is about 845 cubic meters.' At Argorne, all waste suitoble for burial has been shipped to Sheffield, Illinois, o commercial burial site.

\subsection{HANFORD RESERVE}

Past land burial proctices at this site are of interest because they give historical insight to the attitudes prevailing of various periods. From 1944 to 1954 there was no serious segregation of different types of low-level radioactive waste. Combustibles and noncombustibles were buried in the same trench. Buriol records were incomplete and there was a minimal amount of information as to the quantity or type of radiooctive material. From 1955 to 1965 there wos an increased interest in developing on olternate disposal method. Recordkeeping was improved and more faithfully maintained. From 1966 to 1974 a program of centrolization of the buriol grounds in the 200 Area was started and completed. The measurements of the kinds and amounts of radioactivity in the buried wastes improved. Sites were marked with informative semipermanent markers. Recordkeeping was further improved as segregation of radioactive waste by cotegories was initiated. Since 1970, in keeping with the modified policy of DOE, îransuranium waste has been kept separotely in a retrievable form. ${ }^{16}$

A detailed discussion of the Henford Reserve is presented in Appendix B. 


\subsection{IDAHO NATIONAL ENGINEERING LABORATORY (INEL)}

At Idaho Falls, the AEC built reprocessing focilities in the early 1950's to reprocess spent fuel from its research reactors. INEL is also the site for reprocessing spent fuel from the Novy's nuclear program. The amount of fuel ieprocessed there, however, is quite small in comparison to Hanford and Sovonnoh River. Only 11.4 miltion liters of high-level waste are now stored at INEL oifter more than 20 years of reprocessing. The waste has been retoined in its ocidic form unlike the waste at Honford and Sovaninah River. Acid wastes from INEL processing operations are tronsferred to stainless steel holding tanks. There are currently 15 of these tanks. Eleven tanks are contained in the underground concrete voult. The four 11,000 liter tanks are buried on a concrete pad but are not surrounded with a voult. These tanks are used to store waste from early reprocessing operations and are presently empty. No tank failures have been recorded of $\mathbb{N E E L}$. At $\mathbb{N E L}, \mathrm{DOE}$ constructed a calcining facility and began operations in 1963. In this process, the liquid acid waste in the holding tonks is converted to a dry granular solid. Colcinotion also results in o 9:1 volume reduction in waste. The granules are stored in stainless steel bins which are placed in buried concrete vaults. About 6,000 cubic meters of tronsuroniumcontaminated solid waste is shipped annualiy to the INEL for storage, primarily from Rocky Flats operations. This material was forinerly buried in pits, but waste above the 10 nanocuries per gram level is now stored on asphalt pads under sheets of plastic and plywood with a compacted earthen cover. The waste is contained in plastic-lined 208-liter drums or special fiberglass reinforced plastic covered boxes. This facility provides retrievable storage for alpha emitting wastes. A similar pad is used for disposal of radiocrivive waste with high salt content and low plutonium content which is not cur rently io be retrieved. 1,21

A detailed discussion of INEL is presented in Appendix C.

\subsection{LOS ALAMOS SCIENTIFIC LABORATORY (LASL)}

LASL acts as a burial site for solid waste. LASL produces a large variety of contaminated solid woste of which the principal contaminent of concern is Pu239. Non-TRU waste is usually packaged in plastic bogs and fiber containers only 
strong enough to provide contamination control enroute to and at the burial site prior to emplacement in large pits to be covered with soil. Fission product wastes with high garmma radiation readings are handled separately, shielded during transport and at the burial grounds, then placed in specifically drilled shafts in the burial area.

About 80 percent of all radiocetive waste that has been buried is contaminated with transuranium alements and includes a large amount of Am-241. In 1974 the annual burial was $32,020 \mathrm{Ci}$ and $4,071 \mathrm{mi}^{3}$ of solids including the binding or encasing materials. Plutonium, primarily Pu-239, in the solid waste amounts to about 150 grarns per year and about five kilograms accumulated prior to the time retrievable storage of TRU-contaminated waste was instituted.' Appendix $E$ provides a more detailed discussion of LASL.

\subsection{MOUND FACILITY}

No waste is of present buried on-site. Some building rubble conteminated with plutonium was buried in the past and the burial site is well identified and frequently monitored. All current waste is shipped off-site for burial at a commercial burial site or for burial/storage at a DOE site.

The Mound Facility generates a miscellaneous kind of solid waste which results from the treatment of liquid waste streams. The principal contaminont is Pu-238 with some Pu-239. The usual amount shipped each year is about 2,350 $\mathrm{m}^{3}$ and of this cbout 75 percent is plutonium-contaminated. About 10 percent of the solid waste is a result of treatment of $23,000 \mathrm{~m}^{3}$ of a liquid stream.' A detailed discussion of the Mound Focility is presented in Appendix E.

\subsection{OAK RIDGE NATIONAL LABORATORIES (ORNL)}

Historically, a variety of systems have been used for the lond burial of solid lowlevel radioactive waste. Early in the operations of ORNL the solid waste storage areas were small and were located at the main ORNL site. Wastes were dumped into trenches and backfilled. ito records were kept of the quantity or kind of 
solid waste. In foct, it is quite possible that fluid combustibles were also buried. It is also likely that little fissionable material is in the waste becouse an extreme effort was made ot the time $t$. conserve it.

During the period of 1955-1963 ORNL was the southern region storage area for solid wastes. About $28,000 \mathrm{~m}^{3}$ of solid rodioactive waste were derived from the nuinerous sources of reseorch and operation waste sent to ORNL burial. The variety, character and even the anount of radioactive wastes acquired in this woy are unknown.!

At ORNL the solid radioactive woste is generated in a number of woys and forms. The most bulky and least contaminated is laborotory refuse. It cansists of cnimal carcosses, cnimal wastes, glassware, rubber and synthetic rubber goods, paper, rags and a miscellany of items either known or suspected to be contaminated with rodioactive material. Another source of lesser volume comes from the variety of chemical and physical research and development $\alpha$ tivities. There is also the usual array of discarded equipment, mochinery, tools, tanks, valves and pipes that are no longer needed or are so radioactive as to preclude successful economic decontamination. Finally, there is soil, concrete flooring, and building materials contaminated by spills and leaks. It is anticipated that there will be need for the burial of obout $3,000 \mathrm{~m}^{3}$ per onnum for the next 10 years at ORNR. A detailed discussion of all Oak Ridge focilities is provided in Appendix $E$.

\subsection{ROCKY FLATS PLANT (RFP)}

At present no radicactive waste is being buried at Rocky Flats. In the past, some burials occurred locally, but mast of the plutonium contained in the waste has been retrieved and shipped to the Idaho National Engineering Laboratory (INEL). The small remainder is in a known location and is under surveillance. The wastes currently shipped to INEL are stored in a retrievable tronsuronium storoge area if the contomination level exceeds 10 nanocuries of tronsuranium nuclides per gram of waste. About 50 percent of the radioactive solid wastes presently produced by the Rocky Flats Plant result from the treatment of liquid 
streams. 1,64 The rest is produced by a variety of chemical plants and laboratory operotions.

Shipments of alpho-emitting wastes are made in 208-liter drums or plywood boxes coated with a glass fiber impregnated polyester. Rigid polyethylene liners in the dums and the box coating provide the integrity needed for 20 year retrievable storoge. Wastes not requiring retrievable storage are pockoged only to meet transportation requirements, not to provide control after burial. Alphaemitting waste comprises about 90 percent of the total generated. About 7,000 $\mathrm{m}^{3}$ of alpho-emitting waste is currently generated each year containing about 20 kilograms of plutonium of various isotopic compositions. The $15,500 \mathrm{~m}^{3}$ of liquid wastes when treated produce $3,700 \mathrm{~m}^{3}$ of solids, a reduction to 24 percent of the original volume.'

Low specific activity (LSA) waste consists of non-line generated waste and evoporated salts. Non-LSA waste consists of line-generated waste, first-stage sludge, second-stage sludge, cemented liquids and arganic liquids mixed with calcium silicate to form a putty-like mass called "greasen" Now employed, however, is a more useful operation of classification developed in 1970 at INEL when it become necessury to estoblish the retrievable storage operation. Category one includes poper rags, miscelloneous filters, glass, gloves and general garbuge. Category two includes all metallic waste. Category three includes the sludges, the cemented liquids and "grease." Category four consists of undetined waste. Fortunately, the volume of the last category is small and creates no problem of waste manogement.

Currently, the Rocky Flats operation generates about 20 kilograms of waste plutonium annually. The accumulated Rocky Flots-generated plutonium in the INEL burial site through FY 1975 amounts to about 500 kilograms of which 120 kilograms are in the retrievable storoge. 1,64 


\subsection{SAVANWAHRIVER PLANT (SRP)}

Sovannah River has replaced Hanford as a major production focility for the Government's nuclear defense program, with three production reactors now in operation.' Presently, cbout 80 million liters of high-level waste are stored in corbon steel tanks. DOE is processing high-level waste at Savonnch River into saltcake os at Honford. DOE is presently using 31 tonks for high-level liquid waste storoge, ranging in copacity from 3.7 million liters to five million liters. All tanks are constructed of carbon steel and sit in reinforced concrete voults. Eight hove single steel walls and the others have double steel walls. Another 24 of the largest of the tanks are under construction or planned. 23, 24

The major radionuclides that are buried or stored in many forms of the SRP include the following: $\mathrm{H}-3-2.9$ million curies; $\mathrm{CO}-60$ - 150,000 curies; $\mathrm{Sr}-90$ 4,000 curies; Cs-137 - 4,000 curies; Pu-238 - 309,000 curies; Pu-239 - 1,000 curies; Cm-244 - 40,000 curies.' About 11,300 $\mathrm{m}^{3}$ of alpha-emitting waste were buried before 1965 and chout on equal volume since then. The earlier burials were not encapsulated in concrete. They contained a total of about 200 curies of Pu-239. Since 1965, there hove been some low-level alpho disposals without encapsulation. However, the location of these burials is well known and trial exhumations have been undertaken.

At the Sovarnah River Plant 19,000 curies of Pu-238 waste, 1,000 curies of Pu239 waste from finishing operations, and 40,000 curies of $\mathrm{Cm}-244$ waste from SRP production operotions ae stored along with 290,000 curles of Pu-238 waste from the Mound Focility and LASL in on array of concrete containers designed for ease of monitoring and retrieval.'

A detailed discussion of SRP is presented in Appendix D. 


\subsection{OTHER DOE FACILITIES}

Table 3-2 provides a listing of DOE waste generoting facilities with burial sites and Table 3-3 provides a listing of DOE and subcor.tractors facilities without burial grounds.

1

1.

1

1

D

$\square$

1

1

I

1 


\section{TABLE 3-2}

DOE FACILITIES GENERATING SOLID WASTES

WITHBURIAL GROUNDS (1976)

Site

Feed Materials Production Center

Henford Reserve

Idaho National Engineering Laboratory

Lowrence Livermore Loboratory (Site 300)

Los Alamos Scientific Loboratory

National Lead Company of Ohio

Nevoda Test Site

Oak Ridge Goseous Diffusion Plant (K-25 plent)

Ook Ridge National Loboratory ( $x$-10 plent)

Oak Ridge Y-12 Plant

Poduceh Gaseous Diffusion Plent

Pontex Plant

Portsmouth Gaseous Diffusion Plant

Sendia Laboratory (Kirkland AFB(East))

Sovannoh River Plant

Weldon Springs
Location

Fernald, Ohio

Herford, Washington

Idaho Falls, Idaho

Livermore, Colifornio

Los Alamos, New Mexico

Niagara Falls, New York

Las Vegas, Nevado

Oak Ridge, Tennessee

Oak Ridge, Tennessee

Oak Ridge, Tennessee

Poducch, Kentucky

Amarillo, Texas

Piketon, Ohio

Albuquerque, New Mexico

Aiken, South Carolino

St. Charles County, Missouri 


\section{TAELE 3-3}

DOE FACLITIES GENERATING SOLID WASTES

BUT WITHOUT BURIAL GROUNDS (1976)'

ii

【

I

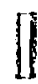

E

Brookhaven Notional Laboratory

Burlington DOE Plant

Fermi National Accelerator Laboratory

Lowrence Berkeley Laboratory

Lovelace Foundation Laboratory

Mound Facility

Naval Reactors Focility

Pinellos Plant

Rocky Flots Plont

Shippingsport Atomic Power Station

\section{Location}

Ames, lo ,

Idoho Falls, Idono

Sonta Susana, Califomio

Kensas City, Missouri

West Mifflin, Pernsylvenio

Upton, L.l., New York

Burlington, lowa

Weston, Illinois

Berkeley, California

Albuquerque, New Mexico

Miamisburg, Ohio

Idaho Falls, Idaho

Clearwater, Floridg

Golden, Colorodo

Shippingsport, Pernsylvania 


\section{COMMERCIAL DISPOSAL SITES}

Since TRU-contaminated solid maste generated at various points in the commercial muclear fuel cycle has historically been disposed of of commercial burial grounds, a description of these grounds is appropriate as part of the background concerning the hendling of TRU waste. The purpose of this section is to provide a brief overview of the commercial disposal sites, while Appendix $F$ presents more detailed information.

\subsection{INTRODUCTION}

Three private componies aurrently operate, or have operated, the six licensed commercial burial grounds. The disposal site location and yea when licensed are presented in Table 4-I.

All commercial disposal sites were licensed to handle by-product, source and special nuclear materials. All sites are on federally-or State-owned land. At five sites the State ouns the land and leases it to the burial ground operators. At the Richland site the Federal government leases the land to Washington, which then leases it to the burial ground operator. All of the sites except Sheffield are licensed for burial by the Stote in which they are located under a Federal agreement giving states this licensing authority. An "Agreement State" is o State that has entered into on agreement with the NRC, which allows the State to control the receipt, possession, use, and transfer of by-product material and quantities of source and special nuclear material not sufficient to form a critical mass. The scope of the ogreement allows the State to license the disposal sites for burial of radioactive wastes, except those wastes resulting from irradioted fuel separation. Since Illinois is not an Agreement State, the Sheffield site is licensed by the NRC, but it also has a State permit to bury waste. The Beatty site, in addition, has an NRC license to bury special nuclear moterial in quentities exceeding State licensoble quantities. At Beatty and Richlond, the NRC regulates the handling of special nuclear material since large quantities are authorized to be hondled by these facilities. The Bamwell site is pursuing a similar license with the NRC. The State regulates the handling of by-product and source moterials at these sites. 3,8 
TABIE 4-1

BURIAL AND STORAGE SITE IDENTIFICATION

Name Operated By

Location

Year Licensed

Beatty Nuclear Engineering Co., Inc. About $17 \mathrm{~km}$ south of Beatty, NV

1962

West Valley ${ }^{(0)}$ Nuclear Fuel Services, Inc. About $50 \mathrm{~km}$ southwest of Buffalo, NY

1963

Morehead ${ }^{(b)} \quad$ Nuclear Engineering Co., Inc. About $20 \mathrm{~km}$ northwest of Morehead, KY

1963

Richland Nuclear Engineering Co., Inc. About $16 \mathrm{~km}$ northwest

1965

Richland, WA

Sheffield $(c) \quad$ Nuclear Engineering Co., Inc. About $8 \mathrm{~km}$ southwest

1967 of Sheffield, IL

Bomwell Chem-Nuclear Systems

About $8 \mathrm{~km}$ northwest of Barnwell, SC

1971
(a) West Valley closed March 1975.
(b) Morehead (Maxey Flats) closed December 1977.
(c) Sheffield's burial trenches ore filled. 
A proposed amendment to the NRC regulations will ben commercial burial of waste contaminated with transuranic (TRU) nuclides. ${ }^{71}$ Since the initial licensing of the Barnwell disposal site in 1971, South Carolina has prohibited the burial of tronsuranic contaminated waste except Am-241. Since October 1973 Hie New York site has not been allowed to receive for burial more then trace quantities of plutonium. In 1974 Kentucky announced that it was limiting the concentration of transuranics to be buried to ten $(10)$ nanocuries per gram and the licensee placed the ten $(10)$ nonocurie limit on waste at the Sheffield site. In September 1975 Nevada placed the same limitation on transuranic materials. ${ }^{8}$

The total volume of solid radioactive wastes buried of commercial sites (Table 4 2) from 1962 through 1977 was chout $5 \$ 6,000$ cubic meters. This waste was estimated to contain about 4.2 million curies of radioactivity uncorrected for decay. About 1,800 kilograms of special nuclear material containing about 123.4 kilograms of plutonium are buried at commercial sites. Of the total waste volume buried at cormmercial sites, Morehead and Barnwell have received the greatest amount; about 27 percent ond 28 percent, respectively (through 1977). Before 1962 commercially generated solid waste was usually disposed of at sea or at the AEC burial sites. ${ }^{3}$

\subsection{COMMERCIAL BURIAL PRACTICES}

The commercial burial sites at Beatty, Nevada; Richland, Washington; Sheffield, Illinois (presently all trenches hove been filled); and Moreheod, Kentucky (no longer in operation), cre operated by the Nuclear Engineering Compony. The West Valley, New York (no longer in operation), site was operated by Nuclear Fuel Services, Inc., and the Barnwell, South Carolina (limited monthly burial rate), site is operated by Chem-Nuclear Systems.

In physical form a great der! of the bulk of waste buried consists of material. which is not radiooctive itself, but which has small amounts of radioactive moterial on its outer or imer surfaces. Exomples of this are poper trash, packing moterial, plostic sheeting and tubing, broken glassware, defective or obsolete equipment, protective clothing, rogs, mops and other cleaning equipment and 


\section{TABLE $4-2$}

COMMERCIAL SOLID RADIOACTIVE WASTE GENERATED ANNUALLY IN THE UNITED STATES ${ }^{19}$

\section{CALENDAR YEAR}

1962

1963

1964

1965

1966

1967

1968

1969

1970

1971

1972

1973

1974

1975

1976

1977

1978
VOLUME $\left(x 10^{3} \mathrm{~m}^{3}\right)$

1.86

6.24

13.10

13.30

16.19

19.38

19.65

21.41

24.98

29.35

37.33

47.08

53.25

57.01

74.22

$(71.36)^{0}$

(80?)

a Preliminariy information. 
building rubble. Another type of contaminated waste in which rodioactive contaminants are much less likely to become physically separated from the nonradioactive bulk of the material include ion exchange resins or filters which have been used to treat radiooctive or potentiolly radioactive water and air effluents, solidified salts resulting from eveporation processes, etc. Other physical forms of solid rodioac tive waste in which the radioactivity is $\boldsymbol{m}$ inherent or inseparable part of the structure or the material in which it is contained consists of discarded shielding, instrumentation, control rods, and other nuclear reactor equipment in which activation of moterials has resulted in the radioactivity. 6,38

In general, the intermediate-level wastes result from liquid-waste treatment or from the removal of equipment or materials from reactors. Wastes are not accepted for burial if they present a significont nonradicactive hazard such as explosion or fire.

Waste packoging is provided to meet Department of Transportation (DOT) requirements and in some cases to permit above ground storage of the waste packoge for short time periods. However, no credit is taken for the contoinment capability of the package after burial, us the soil material is considered to provide the primary containment barrier.

All sites use open trenches or pits as the primary disposal facility. The trenches are about six meters deep but vary considerably in length and width. An overoge burial trench of a commercial burial site is chout $100 \mathrm{~m}$ long, $10 \mathrm{~m}$ wide and $6 \mathrm{~m}$ deep, with a volume of approximately 5,100 cubic meters. This volume is not completely filled with waste packoges becouse of space between packoges of different shopes and becouse of the filling technique and requirements for earth fill. Waste is placed in the trench in a sequential fashion, usually starting at one end, and covered with earth at intervals dependent on the waste type and climate. Trenches containing dy wells or specialized casks are used for the disposal of some higher activity wastes. Trenches at the humid eastern sites are commonly sloped to one end and may contain water-collection facilities at the low end for use during or after trench filling. When the entrenched waste occumulates to within a yord or $s 0$ of the surfoce, a backfill of uncontaminated 
earth is placed over the waste and mounded a few feet chove the original land surface to encourage precipitation runoff. 6

The radioactive materials contained in buried waste range from those with very short half-lives, such as radiopharmaceuticals and some fission products, to longlived materials, such as uronium and plutonium. As shown in Table 4-3, present policies restrict the burial of plutonium at concentrotions obove $10 \mathrm{nCi} / \mathrm{g}$ of waste at all but the Richland site, but some such materials remain in place from previous years.

Radionuclides presently buried at commercial sites are divided into the three categories. These are special nuclear materials (SNM), which are fissionable materials such as U-235 or Pu-239; source materials, such as natural uronium, which con be converted to special nuclear materials in a reactor; and by-product materials, which include all other radionuclides. ${ }^{38}$

The NRC has jurisdiction over the licensing of commercial burial sites, except os it has relinquished that authority to its Agreement States. At present, only the Sheffield site is licensed directly by the NRC, but some octivities, such os the handling of specified quontities of special nucleas materials, are regulated by the NRC at all sites. Federal regulations require that the title to the land used for burial reside with a State or Federal agency. Thus commerciol burial operators have generally purchosed the land and deeded the portions required for burial to the State, which then leases the land to the site operator. Long-term care of the site after termination of operation rests with the landowner, be it a State or the Federal Government. To provide funds for such care, the States collect fees from the burial ground operators. 
TABLE 4-3

BURIAL REQUIREMENTS AT THE SIX COMMERCIAL BURIAL SITES ${ }^{\mathbf{8}, 6}$

\begin{tabular}{|c|c|c|c|c|c|c|}
\hline Requirement & $\begin{array}{l}\text { Beatry, } \\
\text { Nevada }\end{array}$ & $\begin{array}{l}\text { West Valleta) } \\
\text { New York }\end{array}$ & $\begin{array}{l}\text { Morehead, } \\
\text { Kentucky }\end{array}$ & $\begin{array}{l}\text { Pichland, } \\
\text { Washington }\end{array}$ & $\begin{array}{l}\text { Sheffield, } \\
\text { Illinois }\end{array}$ & $\begin{array}{l}\text { Barnwell, } \\
\text { South Carolira }\end{array}$ \\
\hline \multicolumn{7}{|l|}{ Acceptance of waste types: } \\
\hline $\begin{array}{l}\text { Dewatered resins } \\
\text { Dewatered Powdex } \\
\text { Diatomaceous earth } \\
\text { Dewatered sludges } \\
\text { Free liquids }\end{array}$ & $\begin{array}{l}\text { Yes } \\
\text { Yes } \\
? \\
\text { Yes } \\
\text { No }\end{array}$ & $\begin{array}{l}\text { No } \\
\text { No } \\
\text { No } \\
\text { No }\end{array}$ & $\begin{array}{l}\text { Yes } \\
\text { Yes } \\
\text { Yes } \\
? \\
\text { ivo }\end{array}$ & $\begin{array}{l}\text { Yes } \\
\text { Yes } \\
\text { Yes } \\
\text { Yes } \\
\text { Yes }\end{array}$ & $\begin{array}{c}\text { No } \\
? \\
? \\
\text { No } \\
\text { No }\end{array}$ & $\begin{array}{l}\text { Yes } \\
\text { Yes } \\
\text { Yes } \\
\text { Yes } \\
\text { No }\end{array}$ \\
\hline \multicolumn{7}{|l|}{ Solidification ogentss } \\
\hline $\begin{array}{l}\text { All types of cement } \\
\text { Urea-formaldehyde systems } \\
\text { Other organlc polymers } \\
\text { Asphalt/bitumen }\end{array}$ & $\begin{array}{l}\text { Yes } \\
\text { Yes } \\
\text { (b) } \\
\text { (b) }\end{array}$ & $\begin{array}{l}\text { Yes } \\
? \\
\text { (b) } \\
\text { (b) }\end{array}$ & $\begin{array}{l}\text { Yes } \\
? \\
? \\
?\end{array}$ & $\begin{array}{c}\text { Yes } \\
\text { Yes } \\
? \\
?\end{array}$ & $\begin{array}{c}\text { Yes } \\
\text { Yes } \\
? \\
?\end{array}$ & $\begin{array}{l}\text { Yes } \\
\text { Yes } \\
? \\
?\end{array}$ \\
\hline \multicolumn{7}{|l|}{ Selected requirements: } \\
\hline $\begin{array}{l}\text { Retrievability } \\
\text { Plutonium Iimitations }\end{array}$ & $\begin{array}{l}\text { No } \\
\text { Yes }\end{array}$ & $\begin{array}{l}\text { No } \\
\text { Yes }\end{array}$ & $\begin{array}{l}\text { No } \\
\text { Yes }\end{array}$ & $\begin{array}{l}\text { No } \\
\text { No }\end{array}$ & $\begin{array}{l}\text { No } \\
\text { Yes }\end{array}$ & $\begin{array}{l}\text { No } \\
\text { Yes }\end{array}$ \\
\hline
\end{tabular}

(b) Prior to its closing in March 1975.

(b) Prior to its closing in March 


\subsection{CRITERIA FOR DISPOSAL OR STORAGE}

The equirements for burial of solid radioactive wastes of each of the six commercial sites are discussed in Appendix F. It also shows possession limits and permissible concentrations that might affect packaging and shipment of wastes to that particular burial site.

The latest burial requirements at each of the six sites are also given in Appendix F. The criterio for West Valley are those used when the site was accepting waste for burial. More stringent requirements will be enforced when, and if, the burial site is reopened. Although the requirements for the site ore similar, there are certain differences of interest, as follows: ${ }^{6}$

- The West Valley site requires that the contents of any packoge of waste with loose radioactive material and a contact radiation level $>200 \mathrm{mR} / \mathrm{hr}$ on the package be solidified in cement in a metallic container, or in other pockoging approved by the site.

- Liquids must be solidified before burial at all sites except West Valley, where they may be absorbed if pockoge contact yudiation levels are $<200 \mathrm{mR} / \mathrm{hr}$.

- West Valley does not hove a curie limit on the amount of non-tronsuranic by-product material that may be possessed unburied; the other sites hove on unburied possession limit.

- Wesst Valley has a self-imposed limit of one gram per 28.3 $\mathrm{m}^{3}$ for materials containing transuranic rodionsclides in general and Pu-239 in particular.

- The Sheffield, Richland, Beotty, and Barnwell sites accept bulk shipments of liquids and have the authority and copobility for solidification prior to burial.

- A state-imposed restriction ar the West Valley site, not given in Appendix $F$, wass on overage trench concentration ofter burial of $7.1 \mathrm{Ci} / \mathrm{m}^{3}$.

- Sheffield has a state-imposed concentration limit of 35.3 $\mathrm{Ci} / \mathrm{m}$ pockoge. This limit moy be exceeded with special permission. 
Currently, one commercial burial site (Richlond) accepts TRU wastes, with the exception of plutonium, in quantities up to its possession limit for any other byproduct material. This will soon change, however, os the regulatory agency in Washington is also considering adoption of a TRU limit of $10 \mathrm{nCi} / \mathrm{g}$. 


\section{COMMERCIAL NUCAEAR NDUSTRY}

The commerciol nuclear industry typically is understood to include all nuclear fuel cycle octivities. For the purpose of this report other non-fuel cycle waste sources or potential sources will also be briefly reviewed. Figure 2-1 shows the muclear fuel cycle. It is reasonably well accepted that tronsuranic contaminated wastes are primarily generated by the bock end of the fuel cycle. The sources of these transuranic wastes include the fuel fobrication industry and spent fuel reprocessing industry.

\section{I FUEL FABRICATION INDUSTRY}

The commercial nuclear power industry is presently supported in the U.S. by seven major uranium fuel fabricators processing low enriched uranium hexafluoride (UF ${ }_{6}$ ) into finished fuel assemblies of uronium oxide pellets clad in zircaloy tubing. 35 In addition, there are three pilot facilities capable of producing uranium-plutonium mixed oxide (MOX) fuel rods for use in fuel ossemblies. One additional MOX fuel rod plant of commercial production copocity is in the plaming stoge.

The extracted plutonium from the chemical reprocessing step of pent fuel is combined with natural uranium at the mixed oxide fuel fabrication plant to form mixed uranium dioxide-plutonium dioxide fuel pins for recycle to the LWR. This material will contain trace amounts of rodioactive impurities after decomtamination at fuel reprocessing. ${ }^{76}$ in the conventional process, plutonium dioxide powder is blended with cercmic grade uranium dioxide powder, followed by the pelletizing, sintering and mechonical steps employed in the uranium fuel fabrication steps. Residual plutonium is recycled into the main process through a scrap recovery cycle. The fuel assemblies themselves may be fobricated from the loaded fuel rods of the uranium fuel fabrication plant. The finished pellets are loaded into zircaloy twhes and the completed fuel rods are assembled in fixed arroys. Residual uranium and plutonium are recycled into the main process through a screp recovery cycle. 
However, $\mathrm{UF}_{6}$ product from chemical reprocessing will contain small quontities of fission products and transuranium isotopes. Specifications have been published which indicate the maximum acceptable limits for radioactivity resulting from these impurities. ${ }^{76}$ These are: gross alpha due to transuranium isotopes - 1,500 dis/min/(g of $U$ ); gross beto due to fission products and transuranium isotopes -10 percent of the beta activity of aged normal uranium; and gross gamma due to fission products and tronsuranium isotopes - 20 percent of the gamma activity of aged normal uronium. ${ }^{37}$ Such processed uranium moy then be sent to the enriching plant.

\subsubsection{WASTE GENERATION AND HANDLING PRACTICES}

Most of the wastes from processing or fabrication opcrotions and the associated analytical work are generated inside glove boxes. However, a significant amount of waste is generated outside the boxes from contamination control measures. Usually, liquid wastes are segregated from solid wastes and the solid wastes are bagged in plastic. In addition, plutonium-contaminated wastes are often sorted by enrichment level. In piants that con be termed production rather than development facilities, wastes are separated from the wastes that are condidates for disposal by burial.

In general, the solid wastes are the conglomerates arising from the processing and contamination control efforts and consist primarily of paper (wipes and cartons) and plastic (bags). The radioactive constituent is often initially a fine powder. The degree of segregation of paper and plastic depends primarily on the type and extent of scrap recovery. It is estimated that the solid waste stream is about half plastic and half paper, but numerous other constituents are discarded into this stream including clath, rubber (gloves), glasswart, unusable equipment and tools, metal cans, graphite, spent ion-exchange resin, usbestos paper fiber filters, and even small amounts of treated or solidified liquid (usually organics or oil). This solid waste stream is bagged in plastic ond then placed in the plastic lined 208-liter drums. Larger items are crated for burial. 59

Each fuel fabricator has at least four types of wastes: solids from the main process line which are small enough to fit into 208-liter drums, larger sized solid 
waste such as failed equipment, slightly contaminated solids generated in cleanup of small spills outside the main process line and laboratory liquid wastes, Most fobricotors also generate liquid wastes from plutonium processing, scrap recovery or other sources.

\section{I.I.I SOLIDS FROM MAIN PROCESS LINE ${ }^{59}$}

Most fuel fabrication operations ore performed in dy glove boxes. Solid waste includes wipes, neoprene gloves, small failed equipment and small air filters. Most of the waste from glove boxes results from cleanup operations. Major spills are usually recovered by using a paint brush and dust pan. Some processors use vacuum cleaners for more complete removal of dry powders which occumulate in the glove box. Occasional cleanup of the residual powders is necessary to provide proper contamination and exposure contro.. Cleanup is usually by wipes or cheesecloth. Thus, niost of the solid waste from glove boxes is initially cellulose materials. The waste is removed from the box by bagging in PVC and a second PVC bag is often added for additional safety as soon as the first bag is cut from the box. This introduces an appreciable amount of plastic into the waste. Neoprene gloves have to be changed regularly and contribute additional plastic similar to the PVC. If sphincter containers are used, they also contribute either carboard or aluminum to the wastes. Some plastic bottles or carboard containers are often used within glove boxes. Glassware is less common, but might be used by some fobricotors.

Under special conditions cleonup might be accomponied with liquids for more exhaustive cleaning. Usually these are chemically relatively mild, innocuous liquids. Many processors use cheesecloth and nitric acid for cleaning stubbom residues of plutonium. Cloth or pepers sooked with nitric acid are rinsed with woter before being discarded, and often they are neutralized with caustic substances. Since nitric acid solutions are used only in the final stages of cleoning, these materials usually contain only small amounts of plutonium.

Other small items from the glove box are included in this type of waste. Examples are marking pens, tools, prefilters and small failed equipment. If the 
item is smoll enough to fit into a 208-liter drum, or can be reduced to this size easily, it is usually treated the same as other small waste items.

Waste is usually not sorted into various types (e.g., cloth, paper, plastic, tools and equipment) unless one or more types moy contain enough plutonium to make recovery economically attractive. If recovery is contemplated, material is usually sorted into three closses: cellulose, plastic and other. Cellulosic material is incinerated or oxidized and the residue is leached to recover plutonium. Plastics moy be treated similarly to cellulosic materials, or may be leached for plutonium recovery. Leaching of plestics is repoxted to be much more efficient if shredding is done before leaching. Plutonium moy be recovered from other wastes by leaching. Most of the waste reprocessing is only in the planning states or limited to batches of waste which have inusually large amounts of plutonium.

\subsubsection{LARGE FAILED EQUIPMENT ${ }^{59}$}

Some equipment items are not easily reducible in size. Such equipment is cleaned as much as practicable, enclosed in plastic for contamination control and placed in a shipping container. Since large equipment does not fail often, each is treated as a special case at present. Disposal containers are built to fit the particular needs for each shipment. Special pretreatment can also be used to minimize the potential for spread of contamination.

Large air filters are considered and handled as large equipment, even though they are replaced routinely. If they contain appreciable amounts of plutonium, some recovery may be performed. Filters are typically about the size of a $0.6 \mathrm{~m}$ on a side cube consisting of fire resistant filter media in a wooden frome. Prefilters are often used on each individual glove box to reduce the amount of plutonium which con reach the large filters.

\subsubsection{SLIGHTLY CONTAMINATED SOLIDS ${ }^{59}$}

Small occurrences of contamination outside the glove boxes must be cleoned thoroughly. This generates a large volume of waste with very little plutonium 
content. Most of the waste is cellulose and rubber gloves. Cloths or papers soaked with liquids are treated the same as those used in glove boxes. This type of waste could most easily be compacted since the plutonium content is very low and it is the least suitable for scrap recovery. Waste is usually collected in piastic bogs (mostly polyethylene) and deposited in 208-liter drums. All plutonium fabricators use extreme caution to maintain a very clean work area outside of the glove boxes so that normal materials used outside the boxes do not become contominoted.

\subsubsection{CHEMICAL PROCESSING LIQUIDS 59}

Chemical processing liquids for waste disposal originate primarily as aqueous, often acidic, streams that include effluents such as process filtrates, pickling liquids and decontamination liquids. Conventional water treatment steps convert the major rodioactive components into a sludge which is then often solidified by incorporation into a second medium, e.g., cement.

\subsubsection{MISCELLANEOUS LIQUIDS}

In addition to processing liquids, smoll and poorly defined quantities of plutonium-containing organic solutions and vacuum pump oils are generated. The organic solutions include solvents as well as complex chemicals associated with laboratory studies. Some solvents specifically identified are kerosene (used as a lubricant in metallogrophy), trichloroethylene and carbon tetrochloride. In general, current methods of treating or fixing these liquids ore the some as those described above for the processing liquids. The treated miscellaneous liquids are often disposed of along with solids from the main process line, since the incorporation or adsorption step is usually conducted in small vessels inside glove boxes.

\subsubsection{OTHER SOLIDS 59}

A few types of solid waste do not fit oppropriately in any of the above categories since they are not routinely generated, and they may contain significant amounts 
of plutonium. One such waste is spent ion exchenge resins. Usually these are sulfonic acid types which are used in screp recovery operations. Before disposal they are washed with water or diluted coustic substances to remove nitric acid. They may be blended with concrete or air dried ond treated as dry solid waste.

Costing compounds ore used in metallographic or ceramographic examination of fuels and components. Polishing results in finely divided orgonic materials mixed with alpha-emitters. The scale of operations determines the advisobility of recovering the plutonium. Also, the mounted specimen after examination may be discorded if the plutonium content does not warront recovery. Some of the mounting material becomes waste by spillage or deterioration before use. Although the volume is small, this type of waste introduces components not otherwise present in the waste.

Quality control processes often use special chemicals which are introduced in excess of the amount required. Virtually any shemical moy be used for special analyses or for testing new analytical procedures. Usually these are introduced as solutions and eventually become loboratory liquid waste.

\section{I.I.7 MOX FUEL FABRICATION WASTE QUANTITIES}

From the obove discussion, it is understood that the wastes of concern in this study are the liquid and solids generated during MOX fuel fobrication. The liquids include: salt solutions, organic liquids and surfactant/detergent solutions.

The solid wastes are comprised of wet particulate solids, dry particulate solids and combustible and noncombustible solids. ${ }^{50}$ Table $5-1$ presents the sources of the non-high-level fabrication wastes which are anticipated to be TRU or potentially TRU-contaminated.

\subsection{WASTE FROM THE SPENT FUEL REPROCESSING INDUSTRY}

Following a cycle of exposure in the LWR, the spent fuel can be chemically processed to recover the unburned uranium and plutonium and separate the 


\title{
TABLE 5-1
}

\section{SOURCES AND QUANTITIES OF NON-HIGHLEVEL MOX FUEL FABRICATION TRU-WASTES}

\author{
Estimated \\ Waste Volume \\ Waste Cotegory $\quad \mathrm{m}^{3} /$ MTHM $^{(a)}$ \\ Waste Description \\ I. Salt Solutions \\ 0.08 \\ Concentroted scrap recovery, \\ decontamination, and off-gas \\ scrub liquids.
}

2. Surfoctants/Detergent
Solutions

$\sim 0.01$

Laundry wastes, personnel decontamination solutions.

3. Organic Liquids

0.0015

Pneumatic fluids, oils, laboratory solvents.

4. Wet Particulates

0.0003

Bead ion exchonge resins used for liquid effluent treatment.

5. Dry Particulates

- $\quad$ Floor sweepings, etc. Volume not identified.

6. Combustible Solids

0.5

General trash (cellulosics, plastics, rubber - uncompacted).

0.06 Ventilation (HEPA) filters (up to 60 wt\% combustible).

7. Noncombustible Solids

0.2

General trosh, $\mathrm{PuO}_{2}$ cans, etc.

0.2.

Failed equipment, furnace brick.

TOTAL $\quad 1.05$

(a) MTHM - Metric Tons Heavy Metal. Volumes are based on onnual throughput at a lage (4400 MTHM/yr) mixed oxide fuel fabrication plant. Amounts are representative of typical facilities, but not all facilities will hove the full spectrum of wostes. 
fission products for storage or ultimate disposal. The generic spent fuel reprocessing plant is located on a relotively large site and utilizes the Purex process to separate fissile material from the fission products. In this process, the fuel elements are chopped into short pieces, ond the metal oxides are leached by hot nitric $\alpha$ cid, leaving behind the chopped tubing. The nitric acid solution, containing uranium, tronsurarics and fission products, is odjusted chemically and processed through solvent extraction and ion exchange systems. These process steps separote the fission products, uranium and plutonium from each other. The purified uronium product is converted to uranium hexafluoride and is shipped to the gaseous diffusion plant for re-enrichment. The purified plutonium product is converted to $\mathrm{PuO}_{2}$ for recycle to the mixed oxide fabrication plant. The highlevel liquid wastes are stored temporarily on-site in a water-cooled storage basin and ultimately converted to solid form for shipment to the Federal waste repository. 50,36

\subsubsection{TYPES OF WASTES $59,58,60$}

Solid wastes from reprocessing plants can be classified functionally into the following general categories: cladding hulls, intermediate- and low-level waste, general trash, equipment and try chemicols.

- Clodding Hulls - This category is simply the residual fuel element cladding and hardware from the dismentling, shearing, and dissolving operations. Although in many instances other equipment hardware is added with the hulls, the equipment hardware is included in the equipment category for the purposes of this survey.

- Intermediate- and Low-Level Wastes (LW/LLW) - A liquid effluent is generated which is first highly concentrated and then placed in tanks for storage. The liquid is principolly from washing of solvent, decontamination of equipment and chemical digestion (e.g., ion exchange disposal). Another solid which is added to ILW/LLW is metal fines from shearing and sawing.

- General Trash - All solid material which leaves the plant for disposal is termed general trash if it is not specifically included in onother category. For example, off-gas ventilation filters are included os general trash. Also, if plutonium scrop recovery operations are conducted, the woste is included as general trash. 
- Equipment - Obsolete equipment, or failed equipment which is removed from service is included in the equipment category.

- Dry Chemicals - Since some of the plant operations include uranium conversion to $U_{F}{ }_{6}$ the solids originating from this operation are identified \&s dry chemicals.

\subsubsection{SOURCES OF WASTE IN THE SPENT FUEL REPROCESSING INDUSTRY}

For the fuel reprocessing plant, the waste identification is best clarified by discussing each source of waste which potentially contains plutonium.

\subsubsection{FUEL RECEIVING ${ }^{59}$}

The woter basin for receipt and storage of fuels contains o cleonup system which from time to time requires replocement of the ion exchange resin. The plytonium content is generally unknown but is considered TRU-contaminated. Up to $7 \mathrm{~m}^{3}$ of resin are expected to be disposed of each year from larger basins. Disposal concepts and proctices vary. For purposes of this review, the waste from fuel receiving is included as general trosh and wet particulates.

\subsubsection{HEAD END TREATMENT ${ }^{59}$}

The treatment for removal of iodine varies from aqueous scrubbing to silver reactors and silver zeolites. Replacement of the zeolites is onticipated to produce on overall averoge of $\mathbf{0 . 0 0 2}$ cubic meter per metric ton of fuel processed. For disposal, the zeolites are placed in 208-liter drums. However, the plutonium content in this general trash is expected to be negligible. HEPA filters on the dissolver off-gos are replaced periodically except in those plants which use permanently installed filters $(e, g$, sand). The volume of filter replacement varies; the volume of used filters is soinewhat independent of throughput. No measurements or estimates of the amount of plutonium on the filters ore available. The quantity of filters is included as general trash. 
Cladding hulls and pieces of fuel hardware are produced from a chop leach head end in all plants and are included as a separate cotegory. Although there has been some stainless steel cladding and stainless steel parts as well as zirconium, it is anticipated that coout 95 percent by weight of all future cladding hulls and hardware will be zirconium until fast reactor fuels are reprocessed. As shown in Figure 2-2, the amount of plutonium in the hulls is nominally 0.1 percent of the total plutonium in the fuel processed. This is expected to be somewhat lower with longer fuels (because fewer pieces exist with only one end open). Thus, in general the plutonium content is estimated to be cbout 0.02 percent to 0.1 percent of throughput. The volume of the hulls and hardware ronges from 0.3 to 0.55 cubic meter per metric ton.

\subsubsection{GENERAL TRASH ${ }^{59}$}

Most of the material accumulated throughout a reprocessing plant is handled in the form it is collected. Some classification of the waste occurs becouse it is accumulated at a specific location in the plant or because of its high betagamma activity. Typically, this general trash is composed of electrical cords, lights, wire cables, small equipment, glass, rags, paper and cotton wipes, clothing, floor sweepings, tape, rubbers, lead, iilters, manipulator boots and sleeves and all forms of plastic. Estimates of the anount of combustible material vary from 50 to 70 weight percent if the plastics are considered noncombustible. In some cases the noncombustible was estimoted at 10 percent with up to onother 10 percent being moisture. The volume of general trosh (including TRU-contaminated material) ranges from 1 to 9 cubic meters per metric ton of fuel processed. Where filters are routinely replaced in the plant, the volume of filters will overoge from 0.02 to 0.2 cubic meter of filters per metric ton.

\subsubsection{EQUIPMENT DISPOSAL ${ }^{59,73}$}

Periodic failure of equipment requires the disposal of all sizes and shapes of equipmerit. Smaller pieces con be handled in the same manner as the clodding hulls. For example, pipe jumpers, valves, pumps, etc., can be sawed into small 
pieces and stored with the cladding hulls. Larger pieces of equipment require speciai handling in plywood or concrete boxes. Each situation is considered spuccial.

The amount of equipment disposal varies ond, of course, peaks during a maintenance period and/or a process change. No equipment may be sent to burial for one to two years, but a considercble amount onother year. The size may ronge from 2 to 4 square meters and up to $12 \mathrm{~m}$ long. In terms of equipment volume per metric ton, cbout 0.03 to $0.3 \mathrm{~m}^{3}$ per metric ton is expected.

The cmount of plutonium contained on or in a piece of equipment is not measured directly. Analysis of decontaminating solutions indicates a low level of contamination. From typical surface dose readings, not more than about a gran of plutonium is expected to be on a rather large piece of equipment if plutonium is not held up in sludges or cokes.

\subsubsection{DRY CHEMICALS ${ }^{59}$}

If the conversion of the uranium to UF 6 occurs at the reprocessing focility dry chemicals require disposal. In one instance this waste is about 85 percent AIF $_{3}$, 10 percent $\mathrm{Al}_{2} \mathrm{O}_{3}$, and five (j) percent $\mathrm{NoF}$ and $\mathrm{MgF}_{2}$. The total volume is expected to be chout $0.3 \mathrm{~m}^{3} / \mathrm{MT}$. In onother approoch the volume is expected to be about $0.1 \mathrm{~m}^{3} / \mathrm{MT}$ and be principally $\mathrm{Ca}(\mathrm{OH})_{2}, \mathrm{CaF}_{2}$ and $\mathrm{Al}_{2} \mathrm{O}_{3}$. The plutonium content is quite small since the partitioning during solvent extraction is expected to be good. Less thon 0.1 percent of the plutonium throughput is lost to the uranium and eventually to dry chemical waste.

\subsubsection{QUANTITY OF WASTE PRODUCED ${ }^{59}$}

The quantity of waste produced in the spent fuel reprocessing industry can best be reported by using the classifications of waste type discussed previously. The amount of plutonium in each type of waste is shown as a function of plutonium throughput in Toble 5-2. The values given for the probable average are for the situation where the reprocessing plants are operating of near capacity levels. 
TABLE 5-2

PLUTONJUM IN SOLID WASTE ${ }^{59}$

\section{Pu in Solid Waste \\ Percent in Pu Throughput}

Waste Type

Range

Proboble Average

Cladding Hulls

0.02 to 0.1

0.07

ILW/LLW

0.01 to 0.2

0.1

General Trash

0.001 to 0.3

0.05

Equirment

Dry Chemicals

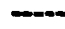

$0.0002^{(0)}$

0.01 to 0.1

0.01

Total

0.04 to 0.7

0.23

(a) Surfaces assumed to be decontaminated thoroughly, with no residual sludge. About one gram of $P_{u}$ expected for each large piece of equipment. 
Table 5-3 lists the solid waste volume for each type of waste. The numbers in the table represent actual waste volume os a function of fuel reprocessing rate. Additional space will be required for storage due to the irregular shapes of packages and for shielding. The volume of general trash is somewhat independent of throughput and is estimated to be $1,200 \mathrm{~m}^{3}$ per year per plant. Likewise, the volume of waste occupied by failed equipment is estimated to be $150 \mathrm{~m}^{3}$ per year per plant.

\section{2 .4 \\ ACTINIDE CONTENT ${ }^{59}$}

Reliable information on the amount of plutonium in the solid waste is lacking because, in general, measurements are not made to verify the quantities. Little is known about the composition of other isotopes in the waste. Only assumptions can be made, bosed on the fission spectra and the source of waste in the process. For example, neptunium is expected to overage about $1 / 20$ of the plutonium content. Table 5-4 presents some assumed characteristics at the presently closed NFS facility at West Volley, New York. These values compare favorably with the information provided above.

The relative proportion of each type of waste is shown in Table 5-5 for plutonium content. The distribution of plutonium is expected to remain foirly constant through the years, with about 75 percent of the plutonium being associated with the cladding hulls and the ILL/LLW cotegories.

Prediction of waste production becomes tenuous due to the numerous uncertainties involved in future nuclear capacity as well as waste and residual management practices. For example, the size of a plant, the extent of residual recovery, changes in regulations, the cost of waste disposal, and the value of plutonium are important and interrelated factors in determining the fraction of plutonium throughput which will be lost as waste. A recent analysis of the TRUcontaminated waste sources and quontities, presented in Table 5-6, generally supports earlier evoluations discussed obove.

The fraction of plutonium lost during processing is expected to decrease as the throughput increases. This trend assumes that the fractional loss will decrease 
TABLE 5-3

ESTIMATED VOLUMES OF SOLID TRU-WASTE ${ }^{59}$

\section{Cubic Meter per Metric $\operatorname{Ion}^{(0)}$}

\section{Waste Type}

Cladding Hulls

ILW/LLW

General Trash

Equipment

Dry Chemicals
Range

0.3 to 0.55

0.06 to 0.4

0.03 to 10

0.03 to 0.3

0.1 to 0.3
Probable Average

0.4

0.2

(b)

(c)

0.15 (a) Volume of actual waste. Packaging, shielding and the irregular shope of
packoges may increase the space required for storoge by a factor of up to
3 .

(b) Volume of general trash is independent of processing rate. Assumed to be $1,200 \mathrm{~m}$ per year per plant.

(c) Volume of equipmentz waste category is independent of processing rote. Assumed to be $150 \mathrm{~m}$ per year per plant. 
TABLE 5-4

RADIOACTIVE WASTES GENERATED ANWUALLY AT NFS DESIGN RATE (750 TONNES/YEAR) ${ }^{73}$

Intermediote Level Woste
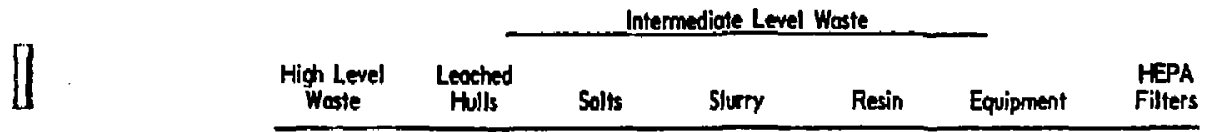

\begin{tabular}{|c|c|c|c|c|c|c|c|}
\hline quantity $\left(\mathrm{m}^{3}\right)$ & 40 & 260 & 135 & 46 & 21 & 300 & 57 \\
\hline $\begin{array}{l}\text { Percent } \\
\text { of total }\end{array}$ & 1.3 & 8.3 & 4.3 & 1,5 & 0.6 & 9.3 & 1.8 \\
\hline $\begin{array}{l}\text { Physical } \\
\text { form }\end{array}$ & Solid & Solid & Slutry & Slutry & Solid & Solid & Solid \\
\hline Chemicol form & $\begin{array}{l}\text { Colcine } \\
\text { oxide of } \\
\text { MPF and } \\
\text { odded } \\
\text { inerts }\end{array}$ & $\begin{array}{l}\text { Zr alloy } \\
\text { or stain. } \\
\text { less steel }\end{array}$ & $\begin{array}{l}\text { Sodium } \\
\text { nitrote } \\
40 \% \text { solu- } \\
\text { tion + } \\
\text { mercuric } \\
\text { iodate }\end{array}$ & $\begin{array}{l}\text { Filter } \\
\text { aid }\end{array}$ & $\begin{array}{l}\text { Organic } \\
\text { and min- } \\
\text { eral resins }\end{array}$ & Metal & $\begin{array}{l}\text { Gereral } \\
\text { dust on } \\
\text { gloss filter }\end{array}$ \\
\hline $\begin{array}{l}\text { Radio- } \\
\text { octivity } \\
\text { (m/find } \\
\text { olume) }\end{array}$ & $\begin{array}{l}99.95 \% \text { of } \\
\text { octivity } \\
\text { in fuel. } \\
s 3.5 \times 10^{6} \mathrm{Cl} \\
\text { of } \mathrm{MFP} / \mathrm{m}^{3}\end{array}$ & $\begin{array}{l}0.05 \% \text { of } \\
\text { cetivity } \\
\text { in fuel. } \\
17,500 \mathrm{cj} \\
\text { Co-60/m }\end{array}$ & $\begin{array}{l}20.40 \mathrm{Ci} \\
\text { of } \mathrm{MFP} \text {. } \\
0.01 \mathrm{Ci} \\
1-129 \\
3.5 \mathrm{~g} \\
\mathrm{Pu} / \mathrm{m}\end{array}$ & $\begin{array}{l}35-350 \mathrm{Ci} / \\
\mathrm{m}^{3} \mathrm{MFP} \\
<10 \mathrm{nCi} \\
\mathrm{Pu} / \mathrm{g} .\end{array}$ & $\begin{array}{l}35350 \mathrm{Cl} \\
\mathrm{m}^{3} \mathrm{MFP} . \\
410 \mathrm{nCi} \\
\mathrm{Pu} / 9 .\end{array}$ & $\begin{array}{l}1,000 \\
\mathrm{mr} / \mathrm{hr} \\
<10 \mathrm{nCi} \\
\mathrm{Pu} / \mathrm{g} .\end{array}$ & $\begin{array}{l}1-500 \mathrm{mr} / \mathrm{hr}, 3 \\
<17.5 \mathrm{Ci} \mathrm{A} / \mathrm{m}^{3}, \\
75 \% 10 \mathrm{nCi}, \\
25 \%+5 \mathrm{mCi} \\
\mathrm{Pu} / \mathrm{g} .\end{array}$ \\
\hline Process & Colcine & 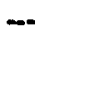 & Dry & hy & Concrete & $\begin{array}{l}\text { Decon- } \\
\text { concrete os } \\
\text { necesery }\end{array}$ & Compoction \\
\hline $\begin{array}{l}\text { Shipping } \\
\text { contoiner }\end{array}$ & $\begin{array}{l}0.5 \mathrm{~m} \times 5 \mathrm{~m} \\
\text { coni: ters }\end{array}$ & $\begin{array}{l}\text { Steel } \\
\text { conisters }\end{array}$ & $\begin{array}{l}\text { Steel } \\
\text { coniste. }\end{array}$ & $\begin{array}{l}218-1 \\
\text { dums }\end{array}$ & $\begin{array}{l}208-1 \\
\text { dums }\end{array}$ & $\begin{array}{l}\text { Speciol } \\
\text { container } \\
\text { es requited }\end{array}$ & $\begin{array}{l}\text { Specio' con- } \\
\text { tainer or } \\
\text { drum }\end{array}$ \\
\hline
\end{tabular}

Final

volumes $\left(m^{3}\right)$

80

260

122

42

440

14

Percent of

totol

3.9

12.8

6.0

2.0

2.0

21.6

0.7 
TABLE 5-4

(CONT.)

\begin{tabular}{|c|c|c|c|c|c|c|}
\hline & \multirow[b]{2}{*}{ Solveni } & \multirow[b]{2}{*}{$\begin{array}{l}\text { Alpha Woste } \\
\text { Combustible }\end{array}$} & \multicolumn{3}{|c|}{ Lov Specific Aetivity Woste } & \multirow[b]{2}{*}{$\begin{array}{c}\text { Total } \\
\text { Volume }\end{array}$} \\
\hline & & & Combustible & Slurry & Solts & \\
\hline $\begin{array}{l}\text { Original } \\
\text { quontity }\left(\mathrm{m}^{3}\right)\end{array}$ & 6 & 480 & 1,000 & 660 & 160 & 3,150 \\
\hline $\begin{array}{l}\text { Percent } \\
\text { of total }\end{array}$ & 0.2 & 15.3 & 31.5 & 21.0 & 4.9 & \\
\hline Physical form & Liquid & Solid & Solid & Slurry & Slurry & \\
\hline Chemical form & $\begin{array}{l}\text { Dillvent } \\
\text { TBP }\end{array}$ & $\begin{array}{l}\text { Paper, } \\
\text { cloth, nub- } \\
\text { ber, plootic, } \\
\text { miscestlonewews }\end{array}$ & Some & $\begin{array}{l}\text { Water terat- } \\
\text { ment, sludge, } \\
\text { Cof, }\end{array}$ & $\begin{array}{l}\text { Sodium } \\
\text { nitrale } \\
40 \% \text { solution }\end{array}$ & \\
\hline $\begin{array}{l}\text { Rodio- } \\
\text { octivity } \\
(\mathrm{m} / \text { /finol } \\
\text { volume) }\end{array}$ & $\begin{array}{l}3,535 \mathrm{Ci} \\
\mathrm{m} M F \mathrm{C} \\
<10 \cdot \mathrm{nCi} \\
\mathrm{Pu} / \mathrm{g} \text {. }\end{array}$ & $\begin{array}{l}\text { s500 mr/hr } 3 \\
\text { s106g Pu/m }\end{array}$ & $\begin{array}{l}200 \mathrm{mr} / \mathrm{hr} \text {. } \\
<10 \mathrm{nCi} \\
\mathrm{Fu} / \mathrm{g} .\end{array}$ & $\begin{array}{l}<200 \mathrm{mr} / \mathrm{hr} . \\
<10 \mathrm{nCi} \text { Puig. }\end{array}$ & $\begin{array}{l}<200 \mathrm{mr} / \mathrm{liter} \\
<10 \mathrm{mCi} \mathrm{Pu} / \mathrm{g} \text {. }\end{array}$ & \\
\hline Process & $\begin{array}{l}\text { Bum or } \\
\text { distill }\end{array}$ & Compoction & $\begin{array}{l}\text { Compoction } \\
\text { of incinero- } \\
\text { tion }\end{array}$ & -- & Dry or obsorb & \\
\hline $\begin{array}{l}\text { Shipping } \\
\text { contciner }\end{array}$ & $\begin{array}{l}\text { Mix with } \\
\text { ILW waste }\end{array}$ & $\begin{array}{l}208-1 \\
\text { dums }\end{array}$ & $\begin{array}{l}2009-1 \\
\text { dums }\end{array}$ & $\begin{array}{l}\text { 208-1 } \\
\text { drums }\end{array}$ & $\begin{array}{l}208-1 \\
\text { drums }\end{array}$ & \\
\hline $\begin{array}{l}\text { Final } \\
\text { volumes }\left(\mathrm{m}^{3}\right)\end{array}$ & 0.3 & 100 & 200 & 595 & 140 & 2,030 \\
\hline $\begin{array}{l}\text { Percent of } \\
\text { total }\end{array}$ & 0.01 & 5.2 & 9.8 & 28.9 & 7.0 & \\
\hline
\end{tabular}

MFP - mixed fission products 
PERCENTAGE DISTRIBUTION OF PLUTONIUM IN SOLID WASTE ${ }^{59}$

7

Percent of Total Pu In All Wastes.

1

Cladding Hulls

32

ILLRLW

42

General Trosh

21

Failed Equipment

I

Dry Chemicals

Total

100 


\section{Estimated Woste Volume \\ Woste Cotegory $\mathrm{m}^{3} / \mathrm{MTHM}^{(0)}$}

I. Solt Solutions

0.3

2. Precipitates and Slurries

0.8

3. Surfoctant/Detergent Solutions

4. Organic Liquids

5. Wet Paticulates

0.01

$0.005-0.01$

6. Dry Particulates

7. Combustible Solids

0.2

0.9

0.16

8. Noncombustible Solids

$$
\text { TOTAL } \quad \frac{0.02-0.4}{2.6-3.0}
$$
0.002 0.034 0.038

\section{Woste Description}

Composited, concentrated decontominations and miscellaneous liquids. lodine scrub solutions.

Water treatment slurry (iron hydroxides, clays, miscellaneous precipitates).

Slurry from UF 6 off-gas treatmerit.

Miscellaneous surfactant-containing decontamination solutions. Nolume included in I, obove.) Laundry wastes may also be included in this category.

Degroded TBP solvent. Miscellaneous lubriconts, oils, hydroulic fluids, lab solvents, etc.

Bead ion exchange resins used to purify solvent and process condensotes. Adsorbents/ion exchange minerals used for condensate and UNH purification.

0.0002-0.006 lodine removal adsortents, zeolites Ruthenium adsorbent beds. UF adsorbent beds. $\mathrm{UF}_{6}^{6}$ fluorinator beds and fines.

Miscellaneous combustible trash (uncompocted).

Miscelloneous combustible trash (uncompacted)

Ventilation filters (up to $60 \mathrm{wt} \%$ combustible).

General trash.

Failed equipment, packaged deep bed filters.

(a) MTHM - Metric Tons Heavy Mietal. Volumes are based on annual throughput of MTHM of a large ( 1500 MTHM/yr) reprocessing plant. Amounts are representative of typical focilities, but not al focilities will hove the full spectrum of wastes. 
linearly from the value of 0.007 (early 1980's) to 0.0025 in 1990's, after which it remains constant. The steady-state volue of 0.0025 was estimated for largescale production. 59

The volume of solid alpha-containing waste which will be generated in the future is likewise uricertain and depends on such factors as changes in regulations and incentive for volume reduction.

\subsection{ENRICHMENT PLANT OPERATION5 ${ }^{37}$}

While laser enrichment and gas centrifugation offer alternatives for future enrichment, the present discussion is limited to the gaseous diffusion plants.

Gaseous diffusion operating experience has been very limited in terms of large throughputs of power reactor refurns. Although there has been considerable production reactor material returned to the cascade, irradiation exposure of that material has been ten- to twenty-fold less than that for power reactors. Experience to date has indicated the following:

- A significant quantity of all non-uranium radiooctivity (neptunium, plutonium, and fission products) is retained in the feed cylinder (UF tank) and will be removed when and where the retumed cylinder is washed.

- PuF ${ }_{6}$ and $\mathrm{NpF}_{6}$ are eosily reduced and therefore removed by trapping with $\mathrm{CoF}_{2}, \mathrm{MgF}_{2}, \mathrm{NoF}$, cryolite, etc.

- Technetium, compared to other fission or alpha emission products, is less likely to be removed by ony process. Experience of Oak Ridge Gaseous Diffusion Plant indicates that technetium release to the environment would be 10 percent of feed to the liquid effluent and one percent of feed to the goseous effluent.

- Experience also indicates that other fission products and alpha radioactivity release fractions should be no more than are-tenth of that for technetium. Measurements of gaseous and liquid effluents have failed to identify any other fission products. However release froctions of one percent to the liquid effluent and 0.1 percent to the gaseous effluent for other fission products will be used below to estimate environmental releases. 
- Cobaltous ffuoride trops exhibit decontamination factors of 400 for neptunium and $10^{5}$ for plutonium prior to feeding to the cascade or conversion facility.

- A large portion of the radioactivity entering a settling pond will be entrained in the sludge of the pond.

The bulk of the radioactivity will be released as solids, either entrained on adsorbote or equipment removed from service for disposal. Liquid woste will be generated by rinsing (decontamination) of recycled equipment. The first rinse solution, which contains the bulk of the radioactivity, is soved to be used as the dilute acid wash solution. Subsequent rinses are sent to the primary holding pond

Gaseous wastes con result from purge system venting, venting of evporator overheads at the uranium recovery facility, and venting of decontamination hoods in the recycle facility. However, the exact breckdown for retention and release factors for each step is not known. One can only make assumptions based on experience with gaseous diffusion. The limited experience available was used to atrive at the estimates in Toble 5-7 about gaseous, liquid, and solid discharges for non-uranium radioactivity.

\subsection{OTIER POTENTIAL SOURCES}

\subsubsection{MEDICAL APPLICATIONS ${ }^{75}$}

During the past 25 years, clinical applications of radioactive materiols hove become a major branch of medicine. In particulat, gamma-ray-emitting isotopes are now commonly used for the purpose of imaging specific areas or organs in the body. The normal technique used in a sconning procedure is to give the potient on injection of the isotope in the eppropriate chemical form to localize it in the desired organ or system, and collect the emitted gammo radiation on an imaging device. In 1972, some 6,355,000 procedures were performed in 3,300 hospitals in 1,500 cities in the United States using rodiopharmaceuticals. ${ }^{74}$ Radioisotopes of iodine were among the first such materials used. Their use in the study of thyroid physiology and in the diagnosis and treatment of thyroid disorders 


\section{TABLE 5-7}

ASSUMED DISTRIBUTION OF FISSION PRODUCTS AND TRANSURANIUM ISOTOPES TO ATMOSPHERE,

PRIMARY HOLDING POND, AND BURIAL GROUND

1

II

$\prod$

lsotope

tioni

Released

Froction

to Atmosphere Holding Pond to Burial Ground

NP-237

$2 \times 10^{-7}$

$4 \times 10^{-6}$

$\sim 1.0$

Other Transuranium

$8 \times 10^{-10}$

$1.6 \times 10^{-8}$

$\sim 1.0$

Tc-99

0.01

0.10

0.89

Fission Products

0.001

0.01

0.989 
(joiv, 000 to 540,000 admis 'strations/year) still make them an important part of the current practice of nuclear medicine.

An excmple of the ropid growth of the use of organ-imaging techniques is the increased cpplication of Tc-99m, an unstoble daughter of Mo-99. Tc-99m is not, in itself, a natural component of ony biological system, but its desirable properties (a six-hour half-life and 140-kev gamma roy which is well-matehed to existing monitoring instruments) moke it ideal for imoging. Becouse of these properties, relatively large amounts of Tc-99m con be administered with little rodiation dose. It is estimated that nearly 5.5 million examinations were performed in 1972 using tectnetium. At present, one of the most useful forms is a pertechnetate used for brain sconning (1,000,000 administrations/year in 1972). Many other isotopes ore now used in scarning procedures: Au-198 or I-13| for the liver $(380,000$ administrations/year in 1972), $1-131$ for the lungs $(246,000$ administrations/year in 1972), $\mathrm{Hg}-203$ for the kidneys (67,000 in 1972), etc. ${ }^{48}$

Isotopes with more energetic emissions, such as Co-60 and Cs-137, are used in thercpeutic situations where the rodiation is used to destroy localized malignoncies. No TRU rodioisotopes are presently utilized in these applications. However, the current generation of heart pocemokers does utilize plutonium as an energy source and as such does make this part of the medical industry a source of TRU-contaminated waste.

\subsubsection{THE WELL-LOGGING INDUSTRY}

Well-logging firms use radioisotopes in down-hole measurements to provide information on the underground strato and to assess o well's sapability for secondary and tertiary recovery. In a typical logging operation, a neutron source and a gamma saurce are placed in on instrumentation package and lowered by means of a coble to the bottom of the bore hole. The pockoge is then withdrawn slowly while the instrumentation detects the neutrons and gamma rays backseatteres from the surrounding strata, and the detected signals are displayed on a chart recorder. The results yield information obout the properties of rock formations as a function of depth. 
Typically, an anericium-beryllium neutron source of five to 20 curies and a $C_{s}-$ 137 gammo-roy source of several curies are used. 48 Each source is enclosed inside two small, stainless-steel cylinders, one inside the other, with welded end cops. Sources are fobricated in o hot cell by a service company, which purchases the radioisotopes from a company having access to a production reactor. Some logging firms and some oil componies olso use radiooctive tracers, usually I-131, $\mathrm{Kr}-85$, or tritiated water, that are injected into o well to monitor its flow properties. Thus the americium-beryllium source is a TRU waste sa rce.

\subsubsection{THE RADIOGRAPHY INDUSTRY}

Radiography sources are made primarily from one of two isotopes, Ir-192 or Co60 , both of which emit relatively high energy gomma roys. The radiation is used to examine the structus al integrity of welded joints, principolly in large pipes, frames, and pressure vessels, or to determine the thickness of a material. No TRU material is utilized.

\subsubsection{LARGE CURIE SOURCES}

Telethercpy sources containing large quantities of $\mathrm{Co-60}$ (up to 10,000 curies) are fabricated and shipped to cancer treatment centers both in the United States and abroad. Irradiator sources, usually $\mathrm{C}_{0}-60$ or $\mathrm{Cs}_{5}-137$, are used for research or in large-scale food sterilization operations and contain hundreds of thousands of curies.

\subsubsection{RADIOACTIVE GAUGING SOURCES}

A number of different gauging techniques use radioactive materials fobricated in sealed-source form. Material thickness is measured by defecting the variation in beta or gamma rodiation that is tronsmitted through the material. Examples are thickness measurements of paper, rubber, plastic sheet, metal foil, and pipe wall. The material level of solids or liquids is measured by detecting a change in transmitted radiation through tanks, bins, boxes, bottles; cans, or other containers. Fluid densities and bulk densities of solids are measured by detecting 
tronsmitted radiation. Coating thicknesses of adhesives, paints, or anticorrosives are measured by detecting transmitted or backscattered radiation. Moisture content is measured by detecting the degree of neutron thermalization.

A number of different isotopes, usually in sealed source form and including Ro226, Cs-137, Co-60, Kr-85, Sr-90, Am-241, Pm-147, and Th-204, are used in the individual sources, which contain from a few millicuries up to several curies of activity. The radiooctive materials used by the source manufacturers ore obtained from suppliers of by-product material. 48

\subsubsection{RADIOISOTOPE THERMOELECTRIC GENERATORS}

$\mathrm{Cm}-244$ is a potentially economic fuel material in heat sources for radioisotope thermoelectric generotors, when recovered from LWR spent fuel. Requirements for the curium include 97 percent minimum product purity.

\subsubsection{OTHER NUCLEAR POWER APPLICATIONS}

The Novol Nuclear Propulsion Program uses highly enriched uranium ! $>90$ percent $U$-235) in a PWR system. Like other reactor types, uranium is enriched as UF 6 by gaseous diffusion for fabricotion into fuel elements. Becouse very little $U$ 238 is present in the fuel, only very small quantifies of plutonium are produced by neutron irrodiation in the reactor. The recovered $U-235$ is re-enriched for reaplication to the fuel cycle. 


\section{TRULCONTAMINATED WASTE NVENTORY}

This section discusses the present TRU-contaminated woste inventory from both DOE facilities and commercial operations. The infarmation is presented from best available data. Some discrepencies are noticed but these reflect differences in reporting periods, accurocy of measurements and differences between generation rotes and buried quantities (due to volume reduction and packoging).

\section{I DOE FACILITIES}

The TRU waste inventory from the DOE facilities, discussed in Section 3.0, includes a diverse number of waste materials and a wide range of radioactivity levels and isotopic composition. It is important to note that the TRU. contominated waste, i.e., obove $10 \mathrm{nCi} / \mathrm{g}$ TRU, only makes up cbout 20 percent of the present annual DOE focilities' waste generation rate. 17 Individual characterization of the DOE generated wasie is provided in Appendices B through $E$.

The TRU waste is currently separated into waste containing greater than $10 \mathrm{nCi}$ of TRU radioisotopes per gram and those containing less. 61 These TRU wastes are also designated as retrievably or non-retrievably stored. The estimated total volumes of TRU waste buried or stored each fiscal year from 1973 to 1976 at DOE sites, show a factor of nearly 2 decrease from $4,695 \mathrm{~m}^{3}$ to $2,240 \mathrm{~m}^{3}$ in nonretrievable storage while the overage annual volume in retrievable form remoined roughly constant of $9,600 \mathrm{~m}^{3}$, with o volume range of $7,630 \mathrm{~m}^{3}$ to $11,800 \mathrm{~m}^{3}$, over the same period. 63

At present, among the DOE installations, the Savannah River Plant (SRP), as shown in Table 6-1, produces the largest annual volume of non-retrievable waste $\left(2,560 \mathrm{~m}^{3}\right.$ or 54.6 percent of the non-retrievable TRU waste stored/buried in FY 1973) with on expected decrease to 2,000-2,300 $\mathrm{m}^{3}$ occounting for 94-99 percent of the total non-retrievable TRU waste enticipated in FY 1976. ${ }^{63}$ Rocky Flats produced the largest total volumes of TRU waste over this time frame $(3,775$ to $6,170 \mathrm{~m}^{3}$ annually), 17 to 23 percent of which is $<10 \mathrm{nCi} / \mathrm{g}$ and is normally stored 

non-retrievably. Only in FY 1975, when a special "sludge clearing" operation was scheduled, did the estimate of this type of non-retrievable waste approach 40 percent. All Rocky Flats TRU waste is shipped to the lcaho National Engineering Laboratory (INEL) for disposal.

An increase in waste Pu stored or buried from a cumulative total of $820 \mathrm{~kg}$ in FY 1972 to $\sim 1,030 \mathrm{~kg}$ in FY 1975 and to obout $1,135 \mathrm{~kg}$ in FY 1977 is shown in Figure 6-1. The Mound Facility, which usually discards 0.5 to $1 \mathrm{~kg}$ of Pu per year, began in FY 1975 to ship such waste to NEL for disposal rather than to commercial burial grounds. The Pu contained in DOE-generated TRU waste shipped to commercial buriol grounds was expected to total $7.2 \mathrm{~kg}$ by the end of FY 1976. The total Pu buried in commercial burial grounds, however, wos estimated at $80 \mathrm{~kg}$ at the end of FY 1974, of $113 \mathrm{~kg}$ at the end of FY 1975, and $124.3 \mathrm{~kg}$ at end of FY 1976. ${ }^{63}$ The difference between these values and the ones reported here from DOE sites are due to commerciolly generated Pu wastes (e.g., from fuel reprocessing and fuel fabrication) that are shipped to commercial burial grounds for disposal. The TRU waste volumes buried or stored at DOE sites and their TRU contents are given in Tables 6-2 and 6-3.

The total volume of waste generated annually is always larger than the annual volume buried and stored because several sites use compoction as a means of volume reduction. Volume reduction factors in the order of $4: 1$ or $5: 1$ are commonly obtained by hydraulic compaction of most ordinary rodioactive wastes, and incineration of combustible wastes con provide volume reduction factors of 20 or greater. Shredding or chopping of waste materials is not as effective in reducing volume as compaction but a 2:1 decrease can be readily achieved. 63

\subsection{COMMERCIALLY GENERATED TRU WASTE}

As indicated in Sections 4.0 and 5.0, the commercially-generated TRU waste includes the waste generated in the nuclear fuel cycle-fuel fabrication and spent fuel reprocessing-as well as numerous miscelloneous R\&D activities and small commercial use of TRU radioisotopes such Am-24l and $\mathrm{Cm}-244$. At present there is no commercial reprocessing of spent fuel and what high-level woste exists is limited to the Nuclear Fuel Services' West Volley facility. 


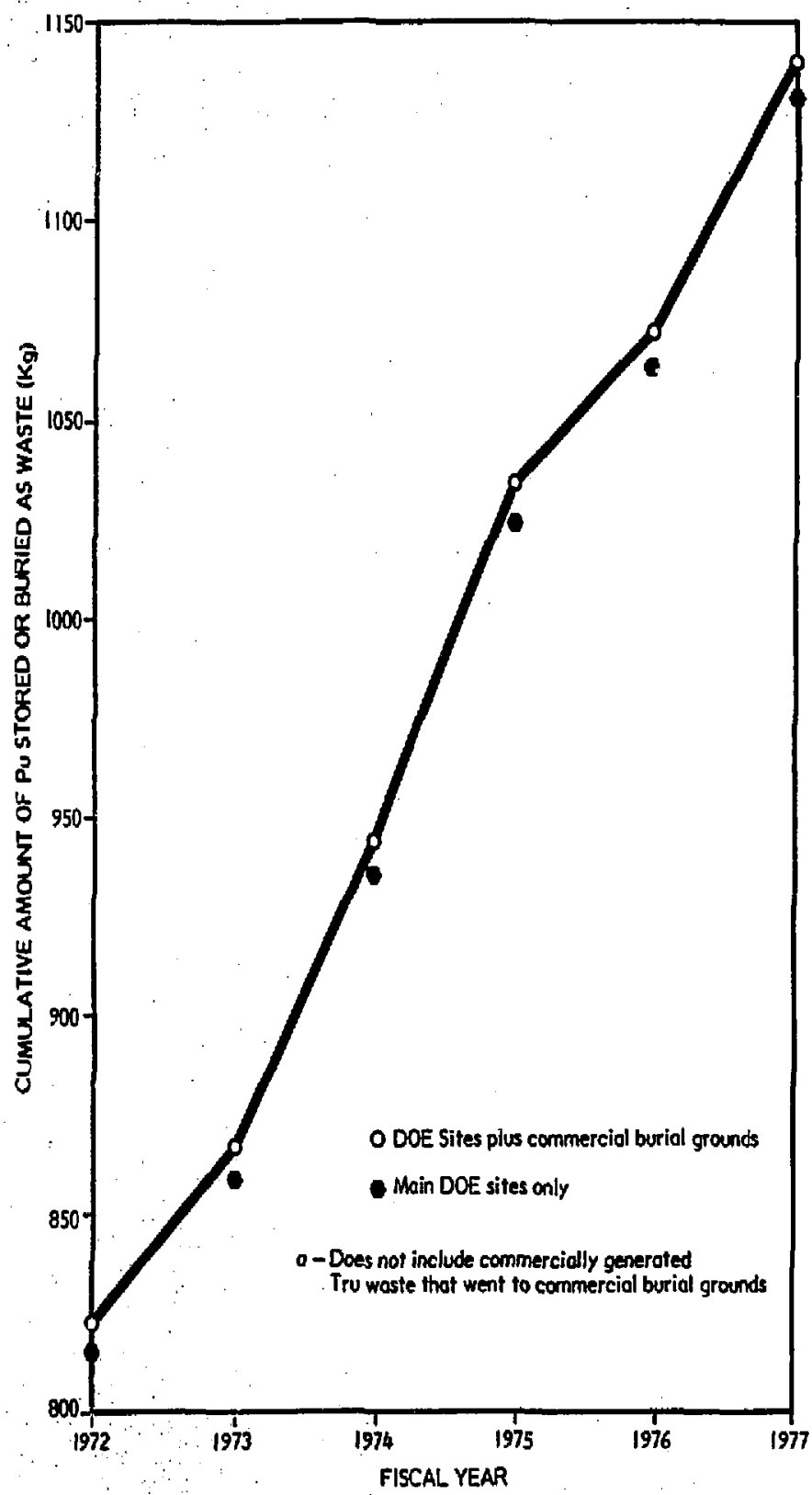

FIGURE 6-I

CUMULATIVE AMOUNT OF DOE PLUTONIUM BURIED AND/OR STORED AS WASTE AS A FUNCTION OF TIME 63,17 


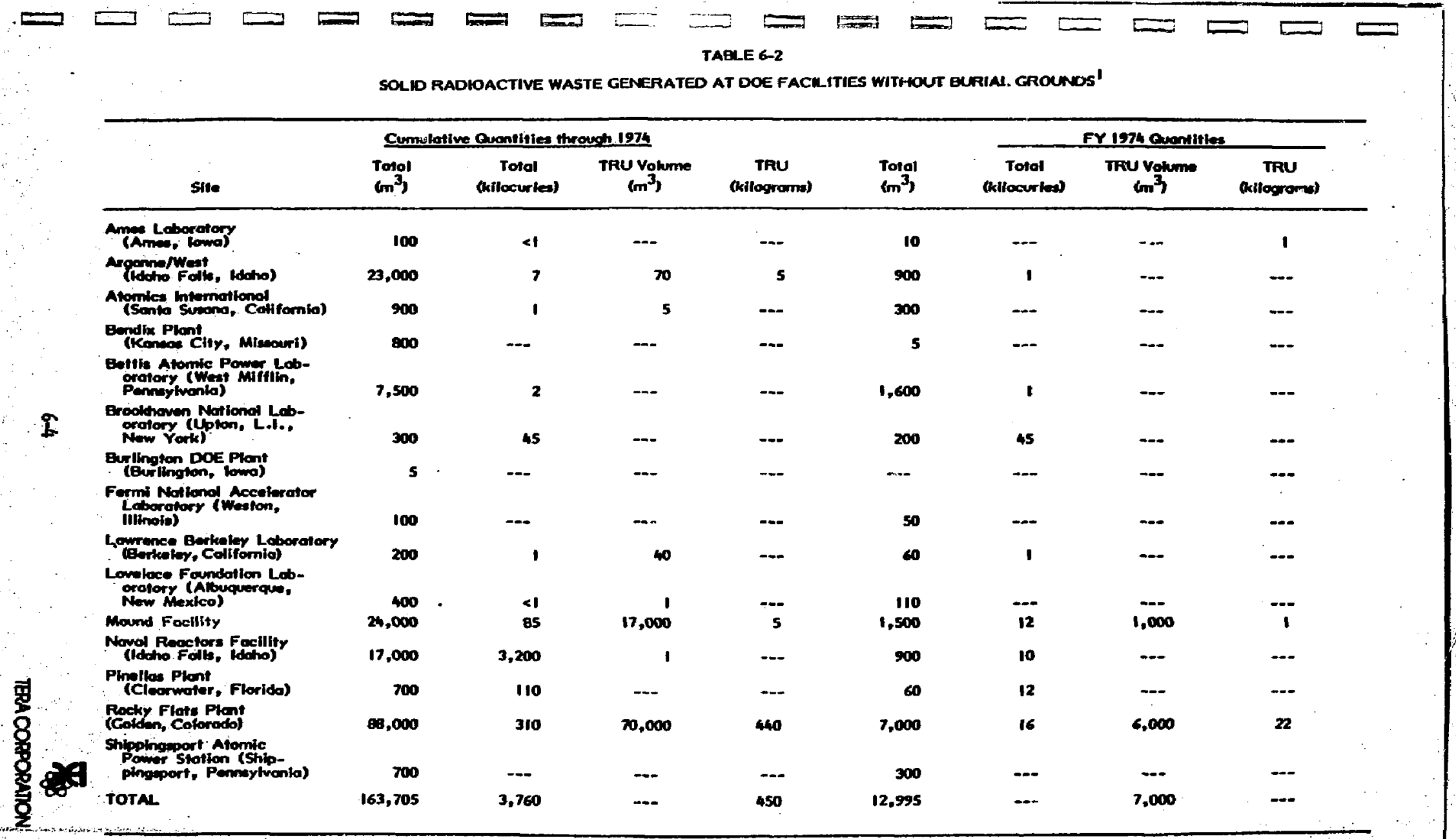


TABLE 6-3

SOLID RADIOACTIVE WASTE STORED AND GUFIEO AT DOE SITES

\begin{tabular}{|c|c|c|c|c|c|c|c|}
\hline \multirow[b]{2}{*}{ Sife } & \multirow[b]{2}{*}{ Hectares } & \multicolumn{3}{|c|}{ Cumulative Guantitles ${ }^{17,63}$} & \multirow[b]{2}{*}{$\begin{array}{c}\text { Anmuol } \\
\text { Rate } \\
\left(\mathrm{m}^{3}\right)\end{array}$} & \multicolumn{2}{|c|}{ Retrienable Storoge $(197)^{17}$} \\
\hline & & $\begin{array}{c}\text { Total } \\
\mathrm{m}^{3}-\end{array}$ & $\begin{array}{l}\text { Volume } \\
\text { (year) }\end{array}$ & $\begin{array}{l}\text { Kilocerries } \\
\text { Buried }\end{array}$ & & $\begin{array}{c}\text { Volume } \\
\left(m^{3}\right)\end{array}$ & $\underset{\text { TRU }}{\text { TRU }}$ \\
\hline $\begin{array}{l}\text { Food Moterials Production } \\
\text { Cenfer }\end{array}$ & 7.6 & 324,311 & (1977) & 0.10 & 175 & -- & $m$ \\
\hline Honford Reservation & 90.4 & 187,596 & (1977) & 2,039 & 6,170 & 7,732 & 67.4 \\
\hline $\begin{array}{l}\text { Idoho Notianol Ensineering } \\
\text { Loborotory }\end{array}$ & 21.0 & 156,150 & (1977) & 3,571 & 6,800 & 32,250 & 266 \\
\hline Lannence Livermore Lobaratory & 2.3 & 700 & (1974) & NA & -.- & -.. & --- \\
\hline Low Alamines Scientifle & 23.1 & 246,350 & (1977) & 2,665 & 4,000 & 1,704 & 27.7 \\
\hline Notional Lead Co. of Ohio & 0.4 & 6,939 & (1977) & $<0.10$ & $\mathbf{a}$ & -- & -- \\
\hline Nevodo Test Site & 64.8 & 7,723 & (1977) & 5.01 & 125 & 90 & 1.3 \\
\hline Ook Ridge Gaseous Diffusion & 0.4 & 1,076 & (1977) & $\ll 1$ & $\cdots$ & -- & --- \\
\hline Ook Ridge National Loboratory & 23.8 & 18,540 & (1977) & 62.65 & 3,170 & 1.319 & 17.8 \\
\hline Ook Ridge $Y-12$ Plont & 2.1 & 32,800 & (1977) & NA & 1,460 & $\cdots$ & $\cdots$ \\
\hline Paducah Gaseous Diffusion Plont & if 0.7 & 6,515 & (1977) & 1.05 & 90 & -- & -- \\
\hline Pantex Plont & 0.4 & 137.7 & (1977) & $\ll 1$ & 1.4 & 0.13 & 2.4 \\
\hline $\begin{array}{l}\text { Portsmouth Gaseous Diffusion } \\
\text { Plonf }\end{array}$ & 0.4 & 279 & (1977) & $\ll 1$ & 4 & --- & -..- \\
\hline Sandia Laboratory & 0.57 & 1,322 & (1977) & 2.4 & 68 & $\mathbf{0}$ & $\mathbf{0}$ \\
\hline Sovarnah River Plant & 37.6 & 273,348 & (1977) & 4,270 & 10,735 & 1,563 & 52 \\
\hline Weldon Springs & 3.0 & 43,047 & (1977) & $\ll 1$ & o & --- & -- \\
\hline TOTAL & 279 & $1,306,834$ & & & 32,799 & 48,658 & 434.6 \\
\hline
\end{tabular}




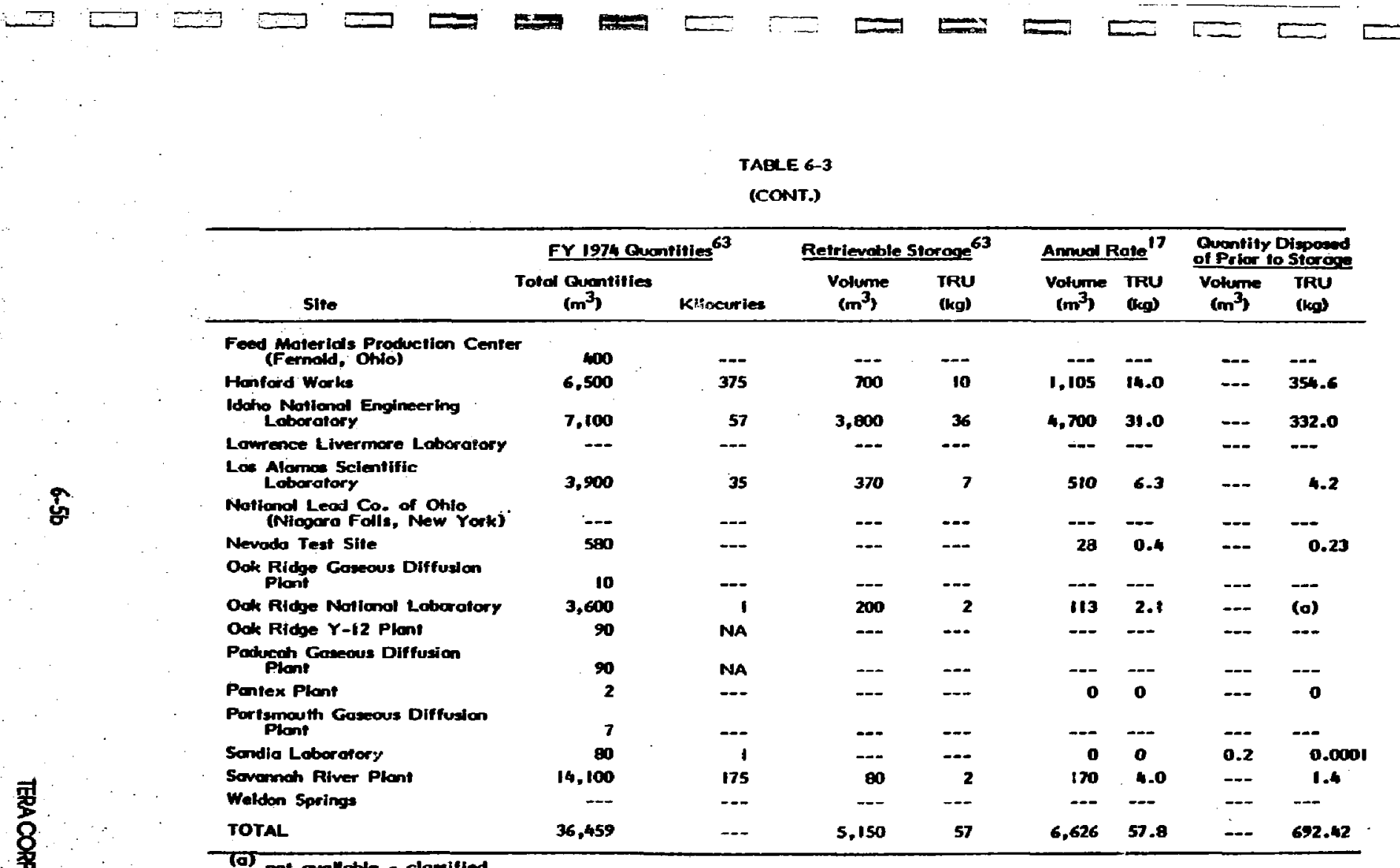

(a) not avollable - clasillied 
The present imentory of TRU and TRU-contaminated waste is limited primarily to DOE-generated waste (shipments now terminated) and I \& $\&$ fuel fobrication activities involving plutonium. These include some R\&D activities in several LWRs as well as the Fast Flux Test Focility project.

Currently about $80,000 \mathrm{~m}^{3}$ of low-level solid wastes are buried each year at the five operating commercial burial sites. The total volume of solid radioactive waste buried at the six commercial burial sites through 1976 is $422,607 \mathrm{~m}^{3}$ $\left(500,000 \mathrm{~m}^{3}-1977\right.$ est.). This waste has about 3.8 million curies (1976) of radioactivity, uncorrected for decoy. About $1,676 \mathrm{~kg}$ of special nuclear material (SNM) is buried ot the sites (1976).

The best available information indicates that the cumulative DOE-generated TRU waste (through 1976) shipped to commercial burial grounds contained about $7.6 \mathrm{~kg}$ of TRU isotapes. The total plutonium buried in commercial burial grounds was estimated at $80 \mathrm{~kg}$ at the end of FY 1974. At the end of FY $1975 \mathrm{on}$ estimated $113 \mathrm{~kg}$ of Pu was buried at the sites or on increase of $33 \mathrm{~kg}$. The cumulative TRU material through 1976 was $123.4 \mathrm{~kg}$. Table 6-4 presents the breakdown of buried waste at the commercial sites. 


\section{TABLE 6-4}

CUMULATIVE WASTE INVENTORY AT COMMERCIAL BURIAL SITES $(1977)^{3,9-14}$

\begin{tabular}{|c|c|c|c|}
\hline Site & $\begin{array}{c}\text { Total } \\
\text { Volume Buried } \\
\left(10^{3} \mathrm{~m}^{3}\right) \\
\end{array}$ & $\begin{array}{l}\text { SNM } \\
\text { (kg) }\end{array}$ & $\begin{array}{l}1974 \\
\text { TRU } \\
\text { (ko) } \\
\end{array}$ \\
\hline Beatty & 58.054 & 688.247 & 14.3 \\
\hline West Valley $(0)$ & 66.726 & 56.003 & 3.6 \\
\hline Morehead & 135.016 & 31.260 & 69.1 \\
\hline Richland & 16.238 & 83.235 & 12.7 \\
\hline effield & 86.634 & 53.962 & 13.4 \\
\hline Iarnwell & 142.873 & 456.863* & - \\
\hline
\end{tabular}

(a) West Valley was closed March 1975

* Cumulative through 1976 


\section{TRUCONTAMNATED WASTE PROJECTIONS}

Besides in inventory of presently buried/stored TRU-contaminated waste it is important to project future waste generation rates and radiooctivity levels to allow policy makers on ossessment vehicle to determine the impoct of o proposed rulemaking change. The purpose of this section is to briefly review past projections and provide an assessment of future TRU generation rates, radioactivity levels and cumulative totals. This section discusses both DOE and commercial waste projections.

\section{I DOE WASTE PROJECTIONS}

While DOE solid radwaste includes fission products and induced activify, uranium, and transuranium (TRU) waste categories, only the TRU will be discussed. The TRU waste is separated into wostes containing greater then $10 \mathrm{nCi} / \mathrm{g}$ and those containing less. These TRU wastes are also designated as retrievable and non-retrievably stored.

As discussed in Section 6.0, the DOE-generated TRU waste has shown a minor decrease since 1973 with a factor of nearly two decrease in non-retrievable storage while the overoge volume in retrievable form remained roughly constant. Table 7-I presents $\boldsymbol{m}$ estimate of future TRU waste burial volumes. These values are somewhat different from the generation rotes and reflect the use of volume reduction technology. Several techniques for volume reduction are now under consideration. Included are efforts to recover uranium and transurium elements by waste-partitioning methods, that is, by separation of waste streams according to their probable isotopic content. Besides this sorting octivity, various tectrologies to compress, shred, incinerate, etc., the generated waste are being utilized. It is cpparent that the most burdensome aspect of future DOE waste manogement is the control of the quentity and the wide and diverse range of waste $m$ rrials. Present DOE waste management programs are designed to control the quantity of waste generated and, as such, while future waste generation rates may increase, the total waste buried should decrease.' 


\section{TABLE 7-1}

ESTIMATES OF FUTURE ANWUAL TRANSURANIUM SOLID WASTE BURIED VOLUME FROM DOE FACILITIES $17,18,63$

Site

Henford Reservation

LASL

NEL*

ORNL

Savannah River Plant

Other DOE Focilities

TOTAL

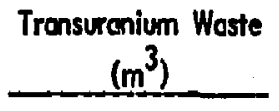

1,105

510

4,700

113

170

28

6,626

* Includes Rocky Flats generated wastes. 
While the onnual TRU waste generation rate is about $12,000 \mathrm{~m}^{3}$ (about $6,600 \mathrm{~m}^{3}$ buried) it is expected that this may decrease in the future due to improved waste management practices and the increased use of volume reduction technologycompaction, shredding, incineration, etc. The corresponding TRU inventory should be less than $30 \mathrm{~kg}$ per year. $1,63,17$

\subsection{COMMERCIAL TRU-CONTAMINATED WASTE PROJECTIONS}

The projection of commercial TRU-contaminated waste fram fuel cycle activities is typically performed by utilizing fuel cycle computer models such as NUFUEL, ENFORM, ORSAC, KWIK PLAN, FLYER, and ALPS. These models have been designed to evaluate the nuclear fuel cycle with emphasis typically on such items as: material and process flow; isotopic composition; mass; volume and composition of process waste streams; economics, etc. For the purpose of this report a number of projections have been reviewed and the projecting basis is presented which most closely reflects the present nuclear and energy policy of the U.S. It is understood that the NRC is presently developing a modularized, integrated computer model for projecting the quantities, physical characteristics and associated storage/disposal costs of commercial nuclear wastes generated on o regional basis through the year 2000 .

\section{2 .1}

\section{WASTE GENERATIONRATE}

The following discussion presents the generation of various TRU-contaminated waste streams. These rates are presented per unit throughput or electrical generation level thus allowing ensy computation of cumulative volumes depending upon the nuclear energy generating capacity scenarios utilized.

\subsubsection{CLADDING WASTE}

Clodding waste consists of solid frogments of zircaloy and stainless steel cladding and other structural components of the fuel assemblies that remoin after the fuel cores have been dissolved. In addition to neutron induced radioactivity, the cladding waste contains 0.05 percent of actinides and 0.05 percent of the 
non-volatile fission products of the spent fuel. It is estimated that after compaction to 70 percent of theoretical density, the final volumes will be 0.07 , 0.08 and 0.25 cubic meter per metric ton of PWR, BWR and LMFBR fuel, respectively. The compocted cladding is packaged in conisters containing 0.1 cubic meter of waste. 49,60

Tables 7-2 and 7-3 present typical TRU-isotopic composition for cladding waste.

\subsubsection{LOW-LEVEL TRANSURANIC WASTE}

Low-level TRU wostes are defined for this report os those solid materials thot contain plutanium and other transuranic long-lived alpho emitters in concentrations greater than $10 \mathrm{nCi}$ per gram yet have sufficiently low external radiation levels that they can be handled safely without shielding. Low-level TRU wastes arise principally of fuel preparation and fabrication plants and enrichment focilities and to lesser extents of fuel reprocessing plants. They consist of a wide voriety of solid materials, including those items mode of paper, cloth, wood, plastic, rubber, glass, ceramic and metals, as well as immobilized salt and sludges that $a$ ise in the treatment of liquid waste streams and filters from cleanup of off-gas. The transuranic element content of these wastes ranges from trace omounts to several grams per cubic meter and overoges about nine (9) grams per cubic meter. The densities of the uncompacted waste vary from $35 \mathrm{~kg}$ per cubic meter to as much os $3,500 \mathrm{~kg}$ per cubic meter; about $1 / 2$ to $2 / 3$ of these wastes by volume are combustible and con be reduced vio incineration by factors of 20 and 10 in volume and weight respectively; cbout $1 / 2$ to $3 / 4$ of the waste by volume con be reduced by factors of two to 10 through impaction. 49

A survey of operotions at DOE laboratories and production facilities indicates that future large plants will generate about 283, 566, and 113 cubic meters of uncompacted low-level TRU waste per ton of plutonium processed for fuel preparation, fabrication, and reprocessing respectively. An average plutonium concentration in the waste is nine $(9)$ grams per cubic meter representing fuel losses of 0.25 percent in preparation, 0.5 percent in fabrication, and 0.1 percent in reprocessing. The isotopic composition of the plutonium ist one (I) percent 
TABLE 7-2

CURIES OF TRU RADIOISOTOPES IN THE CLADDING WASTE FROM ONE METRIC TON OF URANUUM-ENRICHED FUEL ${ }^{4}$

\begin{tabular}{|c|c|c|c|}
\hline & & & \\
\hline & DISCHARGE & 10 Years & 100 Years \\
\hline $\begin{array}{l}\mathrm{Np}-239 \\
\mathrm{Pu}-238 \\
\mathrm{Pu}-239 \\
\mathrm{Pu}-240 \\
\mathrm{Pu}-241 \\
\mathrm{Am}-241 \\
\mathrm{Am}-242 \mathrm{M} \\
\mathrm{Am}-242 \\
\mathrm{Am}-243 \\
\mathrm{Cm}-242 \\
\mathrm{Cm}-243 \\
\mathrm{Cm}-244\end{array}$ & $\begin{array}{l}8.67 \mathrm{E}-03 \\
2.50 \mathrm{E}-01 \\
1.62 \mathrm{E}-01 \\
2.41 \mathrm{E}-01 \\
6.18 \mathrm{E}-01 \\
1.19 \mathrm{E}-01 \\
3.62 \mathrm{E}-03 \\
3.62 \mathrm{E}-03 \\
8.67 \mathrm{E}-03 \\
6.84 \mathrm{E}-00 \\
1.46 \mathrm{E}-03 \\
9.86 \mathrm{E}-01\end{array}$ & $\begin{array}{l}8.66 \mathrm{E}-03 \\
2.63 \mathrm{E}-01 \\
1.62 \mathrm{E}-01 \\
2.42 \mathrm{E}-01 \\
3.85 \mathrm{E}-01 \\
8.99 \mathrm{E}-01 \\
3.46 \mathrm{E}-03 \\
3.46 \mathrm{E}-03 \\
8.66 \mathrm{E}-03 \\
2.84 \mathrm{E}-03 \\
1.18 \mathrm{E}-03 \\
6.73 \mathrm{E}-01\end{array}$ & $\begin{array}{l}8.59 \mathrm{E}-03 \\
1.32 \mathrm{E}-01 \\
1.62 \mathrm{E}-01 \\
2.41 \mathrm{E}-01 \\
5.36 \mathrm{E}-01 \\
1.92 \mathrm{E}-01 \\
2.30 \mathrm{E}-03 \\
2.30 \mathrm{E}-03 \\
8.59 \mathrm{E}-03 \\
1.08 \mathrm{E}-03 \\
1.68 \mathrm{E}-04 \\
2.14 \mathrm{E}-02\end{array}$ \\
\hline Total & $7.05 \mathrm{EOI}$ & $4.07 \mathrm{EO} \mid$ & $3.04 E 00$ \\
\hline
\end{tabular}

BWR

DISCHARGE 10 Years 100 Years

$\begin{array}{llll}\text { Np-239 } & 6.81 \mathrm{E}-03 & 6.81 \mathrm{E}-03 & 6.75 \mathrm{E}-03 \\ \text { Pu-238 } & 1.00 \mathrm{E}-00 & 9.49 \mathrm{E}-01 & 4.73 \mathrm{E}-01 \\ \text { Pu-239 } & 1.52 \mathrm{E}-01 & 1.52 \mathrm{E}-01 & 1.52 \mathrm{E}-01 \\ \text { Pu-240 } & 2.33 \mathrm{E}-01 & 2.34 \mathrm{E}-01 & 2.33 \mathrm{E}-01 \\ \text { Pu-241 } & 5.38 \mathrm{E}-01 & 3.34 \mathrm{E}-01 & 4.67 \mathrm{E}-01 \\ \text { Am-241 } & 1.30 \mathrm{E}-01 & 8.08 \mathrm{E}-01 & 1.69 \mathrm{E}-00 \\ \text { Am-242M } & 5.95 \mathrm{E}-03 & 5.68 \mathrm{E}-03 & 3.77 \mathrm{E}-03 \\ \text { Am-242 } & 5.95 \mathrm{E}-03 & 5.68 \mathrm{E}-03 & 3.77 \mathrm{E}-03 \\ \text { Am-243 } & 6.81 \mathrm{E}-03 & 6.81 \mathrm{E}-03 & 6.75 \mathrm{E}-03 \\ \text { Cm-242 } & 5.08 \mathrm{E}-00 & 4.66 \mathrm{E}-03 & 3.09 \mathrm{E}-03 \\ \text { Cm-244 } & 7.54 \mathrm{E}-01 & 5.14 \mathrm{E}-01 & 1.64 \mathrm{E}-02 \\ & & 3.61 \mathrm{E} & \\ \text { Total } & 6.11 \mathrm{E} 01 & 3.61 & 3.06 \mathrm{E}-00\end{array}$

(a) $8.67 \mathrm{E}-03 \mathrm{Ci}$ is equivalent to $8.67 \times 10^{-3} \mathrm{Ci}$ 
TABLE 7-3

CURIES OF TRU RADIOISOTOPES IN THE CLADDING WASTE FROM ONE METRIC TON OF PLUTONIUM-ENRICHED FUEL ${ }^{49}$

$$
\underline{P W R}^{(a)}
$$

CHARGE DISCHARGE 10 Years 100 Years

\begin{tabular}{|c|c|c|c|c|}
\hline $\begin{array}{l}\text { No-239 } \\
\text { Pu-238 } \\
\text { Pu-239 } \\
\text { Pu-240 } \\
\text { Pu-241 } \\
\text { Pu-242 } \\
\text { Am-241 } \\
\text { Am-242M } \\
\text { Am-242 } \\
\text { Am-243 } \\
\text { Cm-242 } \\
C m-243 \\
C m-244 \\
C m-245 \\
C m-246\end{array}$ & $\begin{array}{l}0.0 \\
1.71 E 04 \\
1.37 \mathrm{EO} 03 \\
2.55 \mathrm{E} 03 \\
6.76 \mathrm{E} 05 \\
1.48 \mathrm{EO} \\
0.0 \\
0.0 \\
0.0 \\
0.0 \\
0.0 \\
0.0 \\
0.0 \\
0.0 \\
0.0\end{array}$ & $\begin{array}{l}1.36 E-01 \\
8.91 E 00 \\
3.37 E-01 \\
1.00 E 00 \\
2.98 E 02 \\
9.29 E-03 \\
1.00 E 00 \\
1.84 E-01 \\
1.84 E-01 \\
1.36 E-01 \\
8.48 E-01 \\
1.35 E-02 \\
2.72 E 01 \\
7.82 E-03 \\
1.50 E-03\end{array}$ & $\begin{array}{l}1.36 E-01 \\
8.64 E-00 \\
3.37 E-01 \\
1.03 E 00 \\
1.86 E-02 \\
9.30 E-03 \\
4.76 E-00 \\
1.76 E-01 \\
1.76 E-01 \\
1.36 E-01 \\
1.44 E-01 \\
1.09 E-02 \\
1.85 E-01 \\
7.81 E-03 \\
1.50 E-0 ?\end{array}$ & $\begin{array}{l}1.35 \mathrm{E}-01 \\
4.35 \mathrm{E} 00 \\
3.36 \mathrm{E}-01 \\
1.06 \mathrm{E} 00 \\
2.60 \mathrm{E} 00 \\
9.30 \mathrm{E}-03 \\
9.64 \mathrm{E} 00 \\
1.17 \mathrm{E}-01 \\
1.17 \mathrm{E}-01 \\
1.35 \mathrm{E}-01 \\
9.58 \mathrm{E}-02 \\
1.55 \mathrm{E}-03 \\
5.90 \mathrm{E}-01 \\
7.73 \mathrm{E}-03 \\
1.48 \mathrm{E}-03\end{array}$ \\
\hline Total & 6.97E05 & $4.22 \mathrm{E} 02$ & 2.20EO2 & $1.92 E 01$ \\
\hline
\end{tabular}

BWR

CHARGE DISCHARGE 10 Year 100 Year

$\begin{array}{ccccc}\text { Np-239 } & 0.0 & 1.09 E-01 & 1.08 E-01 & 1.08 E-01 \\ \text { Pu-238 } & 1.75 E 04 & 9.47 E 00 & 9.04 E-00 & 4.52 E-00 \\ \text { Pu-239 } & 1.17 E 03 & 2.92 E-01 & 2.92 E-01 & 2.92 E-01 \\ \text { Pu-240 } & 2.37 E 03 & 9.44 E-01 & .60 E-01 & 2.92 E-01 \\ \text { Pu-241 } & 5.30 E 05 & 2.49 E 02 & 1.55 E-02 & 2.17 E-00 \\ \text { Pu-242 } & 1.23 E 01 & 7.49 E-03 & 7.49 E-03 & 7.49 E-03 \\ \text { Am-241 } & 0.0 & 1.12 E 00 & 4.25 E-00 & 8.26 E-00 \\ \text { Am-242M } & 0.0 & 1.16 E-01 & 1.10 E-01 & 7.32 E-02 \\ \text { Am-242 } & 0.0 & 1.16 E-01 & 1.10 E-01 & 7.32 E-02 \\ \text { Am-243 } & 0.0 & 1.09 E-01 & 1.08 E-01 & 1.08 E-01 \\ \text { Cm-242 } & 0.0 & 5.79 E 01 & 9.06 E-02 & 6.01 E-02 \\ \text { Cm-243 } & 0.0 & 8.72 E-03 & 7.02 E-03 & 1.00 E-03 \\ \text { Cm-244 } & 0.0 & 1.96 E 01 & 1.34 E-01 & 4.26 E-01 \\ \text { Cm-245 } & 0.0 & 9.05 E-03 & 9.04 E-03 & 8.98 E-03 \\ \text { Cm-246 } & 0.0 & 1.66 E-03 & 1.66 E-03 & 1.63 E-03 \\ & & & & \\ \text { Total } & 5.51 E 05 & 3.39 E 02 & 1.83 E-02 & 1.71 E-01\end{array}$

(a) $1.36 \mathrm{E}-01 \mathrm{Ci}$ is equivalent to $1.36 \times 10^{-1} \mathrm{Ci}$ 


\section{TABLE 7-3}

(CONT.)

\section{LMFBR}

CHARGE DISCHARGE 10 Years 100 Years

$\begin{array}{lclll}\text { Np-239 } & 0.0 & 2.71 E-02 & 2.70 E-02 & 2.68 E-02 \\ \text { Pu-238 } & 2.73 E 04 & 9.40 E 00 & 8.83 E 00 & 4.040 E 00 \\ \text { Pu-239 } & 3.21 E 03 & 1.93 E 00 & 1.93 E 00 & 1.92 E 00 \\ \text { Pu-240 } & 4.66 E 03 & 2.62 E 00 & 2.62 E 00 & 2.62 E 00 \\ \text { Pu-241 } & 1.00 E 06 & 2.96 E 02 & 1.84 E 002 & 2.57 E 00 \\ \text { Pu-242 } & 1.32 E 01 & 7.17 E-03 & 7.17 E-03 & 7.17 E-03 \\ \text { Am-241 } & 0.0 & 1.13 E 00 & 4.85 E 00 & 9.67 E 00 \\ \text { Am-242M } & 0.0 & 5.64 E-02 & 5.39 E-02 & 3.58 E-02 \\ \text { Am-242 } & 0.0 & 5.64 E-02 & 5.39 E-02 & 3.58 E-02 \\ \text { Am-243 } & 0.0 & 2.71 E-02 & 2.70 E-02 & 2.68 E-02 \\ \text { Cm-242 } & 0.0 & 2.77 E 01 & 4.42 E-02 & 2.93 E-02 \\ \text { Cm-243 } & 0.0 & 2.26 E-02 & 1.82 E-02 & 2.60 E-03 \\ \text { Cm-244 } & 0.0 & 7.39 E-01 & 5.04 E-01 & 1.60 E-02 \\ \text { Totol } & 1.03 E 06 & 3.40 E 02 & 2.03 E 02 & 2.13 E 01\end{array}$


Pu-238, 59 percent Pu-239, 24 percent Pu-240, 12 percent Pu-24l and four (4) percent Pu-242. It is assumed thot the wastes are compacted or otherwise reduced in volume by foctors of three to 10 before burial. 49

\subsubsection{INTERMEDIATE-LEVEL TRANSURANIC WASTE}

Intermediate-level transuranic waste is dafined for the purposes of this report as those solids or solidified materiais other than high-level and cladding waste that contain long-lived transuranic alpha particle emitters in concentrations greoter than 10 nanocuries per gram and have ofter packaging typical surface dose rates between 10 and 1,000 mrem/hour due to fission product contamination. About 283 cubic meters of this type of waste containing on average of one gram per cubic meter of plutonium and other actinides are generated of reprocessing plants per ton of plutonium processed. This corresponds to a plutonium lass of about $\mathbf{0 . 0 2 5}$ percent. Like low-level transuranic waste, this waste is assumed to be reduced in volume before buried by a foctor of three to 10.49

\subsubsection{NON-TRANSURANIC WASTE}

Non-transuranic waste is composed of those diverse materiuls that are contaminated with low levels of beta- and gamma-emitting isotopes, but contain less than $10 \mathrm{nCi}$ of long-lived alpha activity per gram. This waste, which is common to all nuclear focilities, generally has a radioactivity level in the range of $\mathbf{0 . 0 3 5}$ to 35 curies per cubic meter. About 566, 1,132 and 227 cubic meters of nontransuranic waste per ton of plutonium will be generated at plutonium conversion, fuel fabrication and fuel reprocessing plants respectively. ${ }^{49}$ This waste is reduced in volume as will be the low- and intermediate-level TRU waste. The overage composition before volume reduction is 35 microcuries per cubic meter of LWR fission products.

\subsubsection{OTHER CONTAMINATED WASTES}

As discussed in Section 5.0, there are other potential TRU-contaminated waste sources. Future projections will be based upon past experience as such data is mode available. 


\subsection{REFERENCES AND BIBLLOCRAPHY}

1. National Academy of Sciences, National Resenrch Council, Commission on Notural Resources, Committee on Radiooctive Waste Manogement, Ponel on Land Burial 1976. The Shallow Land Burial of Low-Level Radioactively Contaminated Solid Waste. Washington, D. C.

2. U. S. Energy Research and Development Administration 1976. Alternatives for Managing Wastes from Reactors and Post-Fission Operation in the LWR Fuel Cycles. ERDA-76-43. Vol. 4 of 5. Moy 1976.

3. U. S. Nuclear Regulatory Commission 1977. "NRC Tosk Force Repart on Review of the Federal/State Program for Regulation of Commercial Low-Level Rodiaxctive Waste Burial Grounds." NUREG-0217. March 1977.

4. Jumps, M. J. 1976. "Current Practices for Disposal of Solid Low-Level Radioactive Waste." Radiooctive Waste from the Nuclear Fuel Cycles. AlChE Symposium Series No. 154, Vol. 72.

5. U. S. Code of Federal Regulations. Title 10, Part 20.

6. Atomic Industrial Forum, Inc., National Environmental Studies Project 1976. "A Survey and Evaluation of Handling and Disposing of Solid Low-Level Nuclear Fuel Cycle Wastes." AlF NESP-008. October 1976.

7. U.S. Atomic Energy Commission, Division of Reactor Development and Technology, 1968. "Land Burial of Solid Radioactive Wastes: Study of Commercial Operations and Facilities." WASH 1/43. Washington, D. C.

8. U. S. Environmental Protection Agency, Office of Radiation Programs, Las Vegas Facility 1976. "Review of State Licenses for Disposal of LowLevel Radioactive Waste by Shallow Land Burial." ORP/LV-76-3. June 1976.

9. Hanford Engineering Development Laboratory 1976. "Nuclear Fuel Cycle and Production Programs Progress Report, July-December 1975." HEDL-TME 76-22. May 1976.

10. O'Connell, M. F. and Holconb, W. F. 1974. "A Summary of Low-Level Radiocctive Wastes Buried of Commercial Sites Between 1962-1973, with Projections to the Year 2000." Radiation Dato and Reports. Decermber 1974.

II. Report to the Congress by the Comptroller General of the United States, 1976. "Improvements Needed in the Land Disposal of Radioactive Wastes-A Problem of Centuries." RED 76-54. 
12. Report to the Congress by the Comptroller General of the United States 1977. "Nuclear Energy's Dilemma: Disposing of Hazardous Radioactive Waste Safely:" EMD-77-41. September 9, 1977.

13. Hearings before the Joint Committee on Atomic Energy, Ninety-Fourth Congress (First Session). November 19, 1975.

14. Ford, Bacon \& Dovis Utah, Inc. 1977. "Determination of a Radioactive Waste Classification System." September 1977.

15. U. S. Energy Research and Development Administration 1977. "Alternatives for 1 ong-Term Monagement of Defense High-Level Radioactive Wastes." ERDA-77-44. Richland, Washington. September 1977.

16. U. S. Energy Research and Development Administration 1975. "Final Environmentol Impact Statement-Woste Manogement Operations." ERDA-1538. Vols. I and 2. Richland, Washington. December 1975.

17. Duguid, J. 0. 1977. "Assessment of DOE Low-Level Radioactive Solid Waste Disposal/Storage Activities. Task 103, Final Report." BMI-1984. Prepared for U. S. Deportment of Energy. Columbus, Ohio: Bottelle. November 30, 1977.

18. Godbee, H. W. and Nichols, J. P. 1971. "Sources of Transuranium Solid Waste and Their Influence on the Proposed Notional Radioactive Waste Repository." ORNL-TM-3277. January 1971.

19. Hanford Engineering Development Laboratory 1977. 'Division of Waste Management, Production and Reprocessing Programs Progress Report for January-December 1976." HEDL-TME 77-40, UC-70. April 1977.

20. Heeb, C. M. and Merrill, E. T. 1974. "Significant Actinide Activities in the LWR and LMFBR Nuclear Fuel Cycle." EPA 5203-75-006. October 1974.

21. U. S. Energy Research and Development Administration 1977. "Final Environmental Impact Statement--Waste Management Operations, Idaho Notional Engineering Loboratory." ERDA-1536. September 1977.

22. U. S. Energy Research and Development Administration 1977. "Alternotives for Long-Term Management of Defense High-Level Rodioactive Wastes, Idoho Chemical Processing Plont." ERDA-77-43. Idaho Falls, Idaho. September 1977.

23. U. S. Energy Research and Development Administration 1977. "Final Environmental Impact Statement--Waste Management Operations, Savonnah River Plont." ERDA-1537. Aiken, S.C. September 1977.

24. U. S. Energy Research and Development Administration 1977. "Alternatives for Long-Term Manogement of Defense High-Level Radioactive Wastes, Savornah River Plant." ERDA-77-42. Vols. I and 2. Aiken, S. C. Moy 1977. 
25. U. S. Energy Research and Development Administration. "Droft Environmental Impact Statement-Management of Intermediate Level Waste at Oak Ridge National Laboratory." ERDA-1553-D. Jonuary 1977.

26. Battelle Northwest Laboratary, 1977. "An Overview of Transportation in the Nuclear Fuel Cycle." BNWL-2066. May 1977.

27. Ook Ridge National Loboratory, 1973. "Commercial High-Level Waste Projections." ORNL-TM-4224. Moy 1973.

28. Oak Ridge National Loboratory, 1974. "Projected Shipments of Special Nuclear Material and Wostes by the Nuclear Power Industry." ORNLTM-4631. August 1974.

29. Bell, M. J. 1973. ORIGEN: The ORIJL Isotope Generation and Depletion Code, ORNL-4628. Oak Ridge National Laboratory. Oak Ridge, Tennessee. Moy 1973.

30. Holcomb, W. F. 1978. "A Summary of Shal low Land Burial of Radioactive Wastes at Commercial Sites Between 1962 and 1976, With Projections." Nuclear Sofety. Vol. 19. No. 1. January-February 1978.

31. Parsons Brinckerhoff Quade \& Douglas, Inc. 1976. "Waste Isolation Facility Description-Bedded Salt." Y/OWI/SUB-76/16506. September 1976.

32. Report to the American Physical Society by the Study Group on Nuclear Fuel Cycles and Waste Monagement. July 1977.

33. U. S. Atomic Energy Commission 1974. Draft Environmental Statement-Management of Commercial High-Level and Transuranium Contaminated Radioactive Waste. WASH-1539. September 1974.

34. U.S. Nuclear Regulatory Commission 1976. "Alternative Process for Managing Existing Commercial High-Level Radioactive Waste." NUREG-0043. April 1976.

35. U.S. Environmental Protection Agency 1973. "Environmental Analysis of the Uronium Fuel Cycle - Part 1-Fuel Supply." EPA520/9-73-003-B. October 1973.

36. U. S. Environmental Pratection Agency 1973. "Environmental Analysis of the Uranium Fuel Cycle - Part III--Nuclear Fuel Reprocessing." EPA520/9-73-003-D. October 1973.

37. U. S. Environmental Protection Agency 1976. "Environmental Analysis of the Uranium Fuel Cycle - Part IV-Supplementary Analysis." EPA520/4-76-017. July 1976.

38. Proceedings of Iriernational Symposium in Denver, Colorado 1976. "Monagement of Wastes from the LWR Fuel Cycle." CONF 76-0701. July II-16, 1976. 
39. Emelity, L. A,; Christenson, C. W.; and Kline, W. H. 1966. "Operational Proctices in the Treatment of Low- and Intermediate-Level Rodiooctive Wastes: Arganne and Los Alamos Laborotories, United States of America." Practices in the Treatment of Low- and IntermediateLevel Radioactive Wastes. STI/PUB/II6. IAEA, Vienna. Pp. IB7205.

40. Enders, J. W. 1967. "Solid Radioactive Waste Disposal ot the Los Alamos Scientific Laborotory." Disposal of Radioactive Wastes into the Ground. 5TI/PUB/156. IAEA. Pp. 17-35.

41. Christenson, C. W. 1968. "Treatment of a Highly Concentrated Waste Solution at Los Alamos Scientific Laboratory by Cement-Vermiculite." Treatment of Low- ond Intermediate-Level Radioactive Waste Concentrates, STIJDOC/10/82. TAEA. Vienna. PP. 59-62.

42. Lennemann, W. L., et al. 1970. "Incineration of Radioactive Solid Wostes-A Report by the AEC Working Group for Incineration." DRAFT. June 1970.

43. Ryan, E. S,; Vance, J. N.; and Maas, M. E. 1966. "Aqueous Radioactive Waste Treatment Plant at Rocky Flats." Practices in the Treatment of Low- and Intermediate-Level Radioactive Wastes. STI/PUB/II6. IAEA. Vienna. Pp. 517-526.

44. Ziegler, D. L. 1968. Plutonium Waste Discards CY-67. CRDL-940561-102. Chemical Technology, Chemistry R and D, the Dow Chemical Compony, Rocky Flats Division. Golden, Colorodo. July 18, 1968.

45. Bray, G. R. 1976. "Other-Than-High-Level Waste." NR-CONF-O0I. Proceedings of Nuclear Regulotory Commission Workshop on the Manogement of Radionctive Waste: Waste Partitioning as an Altemative. June 8-10, 1976.

46. Blomeke, J. D. and Perona, J. J. 1972. "Storage, Shipment, and Disposal of Spent Fuel Cladding." ORNL-TM-3650. Ook Ridge National Laboratory. Oak Ridge, Tennessee. January 1972.

47. Brookhaven National Laborotory 1976. "Critical Review of the Properties of Solidified Rodiactive Waste Packages Generated at Nuclear Power Reastors." BNL-NUREG-50591. December 1976.

48. U. S. Nuclear Regulatory Commission, 1977. "Final Environmental Statement on the Transpartation of Radioactive Materiol by Air and other Modes," NUREG-0170. December 1977.

49. Kee, C. W. et ol. 1976. IJpdated Projections of Radioactive Wastes to be Generated by the U. S. Nuclear Power Industry." ORNL-TM-5427. Oak Ridge National Laboratory. Cak Ridge, Tennessee. December 1976. 
50. U. S. Nuclear Regulatory Commission 1976. "Final Generic Environmental Statement on the Use of Recycle Plutonium in Mixed Oxide Fuel in Light Water Cooled Reactors." NUREG-0002. August 1976.

51. U. S. Department of Energy Stoff, Bottelle Pocific Northwest Laboratory Staff, Selected Federal Government Groups. 1977. 'Droft: Environmental Impoct Statement, Monogement of Commercially Generated Radioactive Waste." September 1977.

52. Battelle Pacific Northwest Laboratories 1974. "High-Level Radioactive Waste Monagement Alternatives." BNWL-1900. Vols 1-4. Richland, Washington. May 1974.

53. Pigford, T. H. 1977. "Properties of Closs A Radioactive Waste: A Review of Adequacy of Available Information for a Generic Environmentol Impoct Stotement for Waste Manogement in a Geologic Repository." UCB-NE 3297 (Droft). December 1977.

54. U. S. Nuclear Regulatory Commission, 1977. "The Nuclear Regulatory Commission Low-Level Radioactive Waste Management Program." NUREG-0240. September 1977.

55. U. S. Environmental Protection Agency 1975. "Low-Level Solid Radioactive Waste in the Nuclear Fuel Cycle." November 1975.

56. Uं. S. Environmental Protection Agency 1977. "Considerations for Environmental Protection Criteria for Radioactive Waste." December 1977.

57. Burkholder, H. C. 1976. "Methods and Data for Predicting Nuciide Migration in Geologic Media." Proceedings of the International Symposium of Manogement of Wastes from the LWR Fuel Cycle. CONF-76-0701. Denver, Colorado. July II-16, 1976.

58. Ang, K. P. 1975. "Quantities of Actinides in Nuclear Reactor Fuel Cycles." LBL-3682. Lowrence Berkeley Laboratory. April 9, 1975.

59. Von Tuyl, H. H.; Winegardner, W. K.; Hilliard, R. K.; and Cooley, C. R. 1970. "A Survey of Alphe Waste Generation and Disposal as Solids in the U. S. Nuclear Fuel Industry." BNWL-B-34. Battelle Memorial institute. Richland, Washington. December 1970.

60. Blomeke, J. D. and Kee, C. W. 1976. "Projections of Nuclear Wastes to be Generated." ORNL-6875. July 1976.

61. U. S. Atomic Energy Commission, 1973. "Radioactive Waste Managemerit." Part 1, AEC Monual, Chapter 0511. Appendix 0511. (Now a DOE Monual Chapter) Approved 19 September 1973.

62. Kvam, Donald J. 1965. "Waste Manogement Practices at Lawrence Radiation Laboratory, Livermore." UCRL-14320. Uhiversity of California, Lawrence Radiation Laboratory. Livermare, Califomia. September 28, 1965. 
63. Oak Ridge National Laboratory, 1976. "A Brief Survey of Solid Radwaste Management at ERDA Installations." ORNL/CF-76/129. April 30, 1976.

64. U. S. Energy Research and Development Administration, 1977. Draft Environmental Impact Statement. ERDA-1545-D. Rocky Flats Plant Site. Vols I and 2. September 1977.

65. Pearson, W. R. 1977. Working Paper "H," Draft of High-Level Waste Rule, 10 CFR Part 60, Long-Term Monagement of Class A Radioactive Waste. December 13, 1977.

66. Code of Federal Regulations Title 10, Part 50, Appendix F As Amended. March 23, 1971.

67. Hebel, L. C.; Christensen, E. L.i Donath, F. A.; Falconer, W. E.; Lidofsky, L. J.; Mloniz, E. M.; Ma: T. H.; Pigford, R. L.; Pigford, T, H,; Rocklin, (3. I.; Silsbee, R. H.; and Wrenn, M.E. "Report to the American Physical Society by the Study Group on Nuclear Fuel Cycles and Waste Management." Rev. Mod. Phy. (in publication).

68. Pochin, E. E. 1976. "Estimated Population Exposure from Nucleor Power Production and Other Rodiotion Sources." Nucleor Energy Agency, Organization for Economic Cooperation and Development, Par is.

69. U. S. Atomic Energy Commission. "Plan for the Manogement of AECGenerated Radioactive Wastes." WASH-1202. January, 1972.

70. Walton, R.D. et al. 1976. "Portitioning-An ERDA Overview." NR-CONF001. Proceedings of the Nuclear Regulatory Commission Workshop on the Monagement of Radioactive Waste: Waste Partitioning as an Alternative, June 8-10, 1976.

71. U. S. Atomic Energy Commission, 1974. Transuranium Waste Disposal; Exemption and Continuing Regulatory Authority (10 CFR Part 150). Federal Register 39 (178): 32922-32923.

72. McElroy, J. L; Bonner, W. F.; and Mendel, J. E. 1976. "Waste Solidification USA." BNWL-5A-5873.

73. North, E. D. 1976. "Solid Waste Generation in Reprocessing Nuclear Fuel, AlChE Symposium Series No. 154 Vol. 72.

74. Brantley, J. C. 1974. "Industry's Role in Transportation of Radiopharmaceuticals." Society of Nuclear Medicine, Annuol Meeting, San Diega, CA. June 12, 1974.

75. Wagner, H. N. 1974. Nuclear Medicine, New York, !. P. Publishers.

76. Ock Ridge National Laboratory 1970, ORNL-4451. "Siting of Fuel Reprocessing and Waste Management Facilities." July, 1970. 


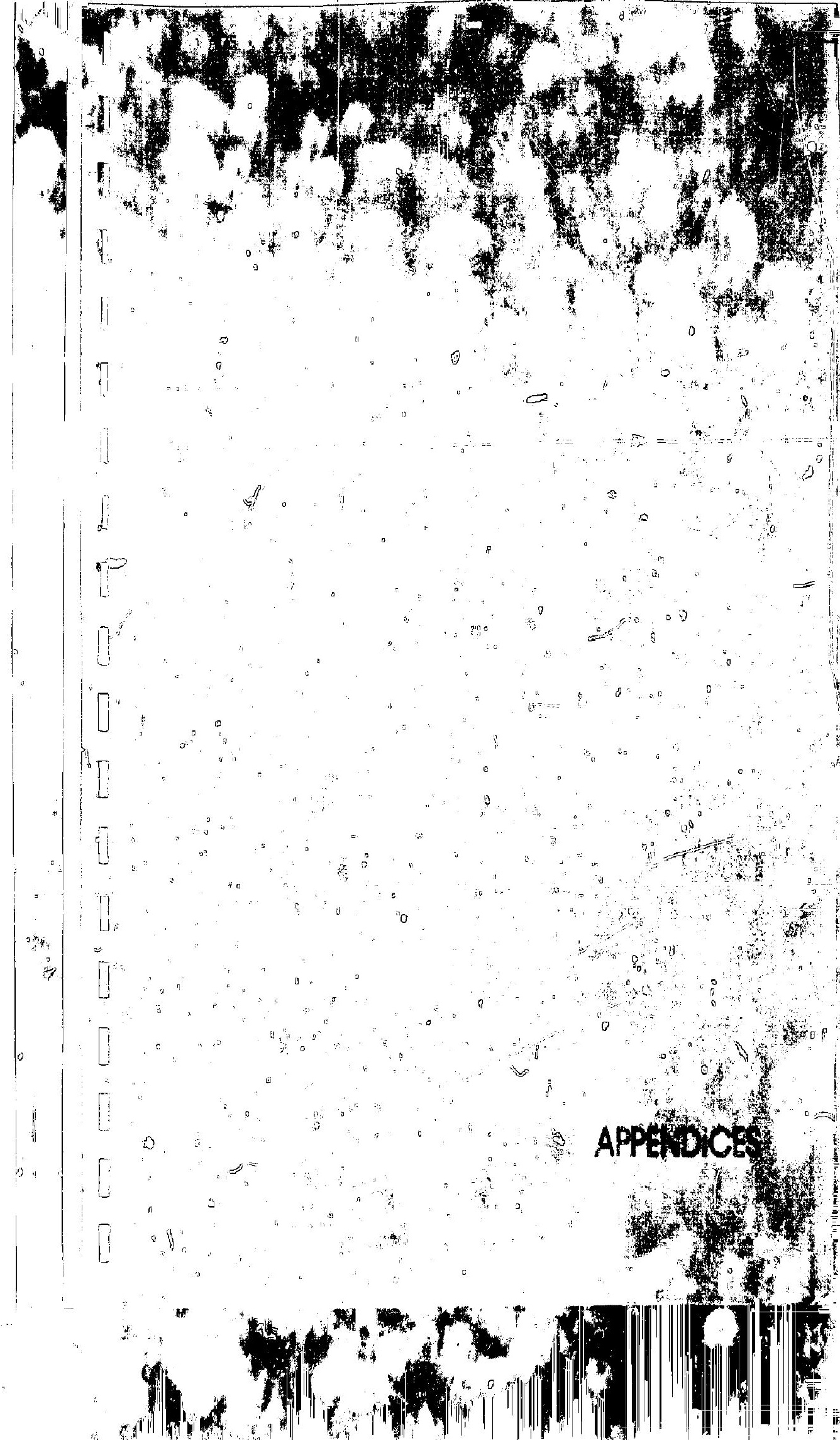




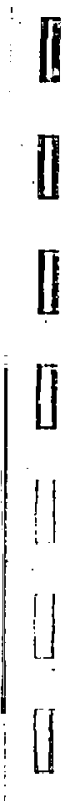

II

II

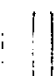

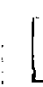

II

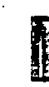

I

[

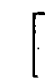

$\Gamma$

1

$\therefore$
APPENDIX A

COSSARY'

AND

METRIC TO ENGLISH CONVERSIONFACTORS 
Actinide Series: The series of elements beginning with actinium, element No. 89 , and continuing through lawrencium, element No. 103, which together occupy one position in the periodic table. The series includes uronium, element No. 92, and all the manmade transuranium elements. The group is also referred to as the "octinides."

Activation: The process of making a material radiooctive by bombardment with neutrons, protons, or other nucleor particles. Also called rodio-activation. The resultant radioactive materials are commonly called activation products.

Activity: A meosure of the rate at which a material is emitting nuclear radiations; usually given in terms of the number of nuclear disintegrations occurring in a given quantity of material over a unit of time; the stondard unit of activity is the curie ( $\mathrm{Ci}$ ).

Alpha Wastet Waste material that is contaminated by radionuclides that emit alpha particles, particularly (in this text) the transuranium elements.

Cladding Waste (hulls): Fuel rods in most nuclear reactors today are made up of fissionable materials clad in a protective alloy sheathing that is relatively resistant to radiation and the physical and chemical conditions that prevail in a reactor core. The spent fuel rods, after removal from the reacto- and storage to permit radioactive decay of the short-lived fission products, are removed and in certain fuel cycle processing systems are chopped up, and the residues of the fissionable materials are leached out chemically. The remaining residues, principally the new rodioactivated cladding material (zirconium alloys, stainless steel, etc.) and insoluble residues of nuclear fuel, fission products, activation products and tronsuranium nuclides, are left behind as cladding waste, which is a special category of transuranium radioactive waste.

Crib: A back-filled burial trench into which intermediate-level liquid waste is distributed through a perforated pipe.

Critical: The condition in which a material is undergoing nuclear fission at a self-sustaining rate; the critical mass of a moterial is the amount that will self-sustain nuclear fission when placed in an optimum arrangement in its present form.

Curie (Ci): $A$ unit of radioactivity defined fo the amount of a radioactive material that has an activity of $3.7 \times 10^{-10}$ disintegrations per second $(\mathrm{d} / \mathrm{s})$; millicurie $(\mathrm{mCi})=10^{-3}$ curie; microcurjo $(\mathrm{Ci})=10^{-6}$ curie; nonocurig ( $\mathrm{nCi})=19^{-9}$ curie; picocurie $(\mathrm{pCi})=10^{-12}$ curie; femtocurie $(\mathrm{fCi})=10^{-15}$ curie.

Decommissioning The process of removing a facility or area from operation and decontaminating and/or disposing of it or placing it in a condition of standby with oppropriate administrative and physical controls and safeguards. 
Decontamination: The selective removal of radioactive moterial from a surfoce or from within mother moterial.

Disposal: The planned release or placement of waste in a manner that precludes recovery.

Engineered Storoge: The storage of rodiooctive wastes, usually in suitable sealed containers, into any of a variety of structures especially designed to protect them from water and weather and to help keep them from leaking to the biosphere by accident or sobotoge.

Fertile Material: A material, not itself fissionable by thermal neutrons, that can be converted into a fissile material by irradiation in a reactor. There are two basic fertile materials, uranium-238 and thorium-232. When these fertile materials copture neutrons, they are portially converted into fissile plutonium-239 and uronium-233, respectively.

Fissile Materials While sometimes used as a synonym for fissionable material, this term has also acquired a more restricted meaning, namely, ony material fissionable by neutrons of all energies, including (and especially) thermal (slow) neutrons as well as fast neutrons; for example, uranium-235 and plutonium-239.

Fission: The splitting of a heavy nucleus into two approximately equal parts (which are nuclei of lighter elements), accompanied by the release of o relatively large amount of energy and generally one or more neutrons. fission con occur spontaneously, but usually is caused by nuclear absorption of gamma roys, neutrons, or other particles.

Fissionable Material: Commonly used as a synonym for fissile material. The meaning of this term also has been extended to include material that can be fissioned by fast neutrons only, such as uranium-238. Used in reactor operations to mean fuel.

Fission Products (F.P.): The nuclei (fission frogments) formed by the fission of heovy elements, plus the nuclides formed by the fission fragments' rodioactive decay.

Fuel (muclear, reactorl: Fissionable material used as the source of power when placed in a critical arrangement in o nuclear reactor.

Fuel Cycle: The complete series of steps involved in supplying fuel for muclear power reactors. It includes mining, refining, the original fabrication of fuel elements, their use in a reactor, chemical processing to recover the fissionable material remaining in the spent fuel, reenrichment of the fuel material, refabrication into new fuel elements, and management of radioactive waste.

Fual Separation (fuel reprocessing): Processing of irradiated (spent) nuclear reactor fuel to recover useful materials as separate products, usually separation into plutonium, uranium, and fission products. 
Half-life (TH): The time in which half the atoms of a particular rodioactive substance disintegrate to another nuclear form. Measured half-lives vary from millionths of a second to billions of years.

Health Physiex The science concerned with recognition, evaluation, and control of health hazards from ionizing and nuclear radiations.

High-level Liquid Woste $0-1 \mathrm{Wh}$ : The oqueous waste resulting from the operotion of the first-cycle extraction system (Purex Process), equivalent concentrated wastes from subsequent extraction cycles, or equivalent wastes from a process not using solvent extraction, in a focility for processing irradiated reactor fuels.

Ion Exchange: A chemical process involving the reversible interchange of various ions between a solution and a solid material, usually a resin. It is used to separate and purify chemicals, such as fission products, rare earths, in solution.

lonizing Rodiation: Any radiation displacing electrons from atoms or molecules, thereby producing ions. Examples: alpha, beta, and gamma rodiation.

Isotope: One of two or more otoms with the same atomic number (the same chemical element) but with different atomic weights. An equivalent statement is that the nuclei of isotopes have the same number of protons but different numbers of neutrons. Isotopes usually have very necrly the some chemical properties, but somewhot different physical properties.

Licensed Material: Source material, special nuclear material, or by-product material received, possessed, used, or tronsferred under a general or special license issued by the U.S. Nuclear Regulatory Commission or an Agreement State.

Long-lived lsotope: A radioactive nuclide that decays at such a slow rate that a quantity of it wili exist for an extended period.

Mon-rem: A unit in health physics to compare the effects of different amounts of radiation on groups of people. It is obtained by multiplying the overage dose equivalent to a given orgen or tissue (measured in rems, which see) by the number of persons in that population.

Nuclidet A species of atom having a specific mass, atomic number, and nuclear energy state. These foctors determine the other properties of the element, including its radiooctivity.

Plutonium (Pu): A heavy, rodioactive, manmade, metallic element with atomic number 94. Its most important isotope is fissionable plutonium-239, produced by neutron irradiation of uranium-238. It is used for recctor fuel and in weapons.

Rad (acronym for radiation cosorbed dose): The basic unit of cbsorbed dose of ionizing radiation. 
Raciation The emission and propagation of energy through matter or space by means of electromagnetic disturbances, which display both wove-like and particle-like behavior; in this coniext the "particles" are known as photons. Also, the energy so propogated. The term hos been extended to include streams of fast-moving particles (alpho and beto particles, neutrons, cosmic radiation, etc.). Nuclear radiation is that emitted from atomic nuclei in various nuclear reactions, including alpha, beta, and gamma radiation and neutrons.

Radioactive Contamination: Deposition of radioactive material in any place where it may harm persons, spoil experiments, or make products or equipment unsuitable or unsafe for some specific use. The presence of unwanted radioactive matter. Also radiooctive material found on the walls of vessels in used-fuel processing plants, or radionctive material that has lecked into a reactor coolant. Often referred to only as contamination.

Radioactivity (often shortened to "octivityl): The spontoneous decoy or disintegration of an unstable atomic nucleus, usually accompanied by the emission of ionizing radiation. The word radiooctivity is often used to refer to radioactive materials or radiooctive nuclides, but this usage is not, strictly specking, correct. Radiooctivity is a process, not a substance.

Radioisotope A radioactive isotope. An unstable isotope of an element that decays or disintegrates spontoneously, emitting radiution. More than 1,300 natural and artifical radioisotopes have been identified.

Radwaste: Woste materials that are contaminated with radioactive materials.

Rem: A unit of meosure for the dose of ionizing radiation that gives the some biological effect as I roentgen of $x$ rays; ! rem equals approximately I rad for $X$, gamma, or beto radiation.

Roentgen (abreviation r): $A$ unit of exposure 10 ionizing radiation. It is that amount of gamma or $X$ roys required to produce ions cartying one (I) electrostatic unit of electrical charge (either positivic or negative) in one (I) cubic centimeter of dry air under standard conditions. Named after Wilhelm Roentgen, German scientist who discovered X rays in 1895.

Shart-lived lsotoper A radioactive nuclide that decays so ropidly that a given quantity is transformed into its daughter praducts within a short period (usually those with a half-life of days or less).

Solid wastes (radioactive): Either solid radioactive material or solid objects that contain radioactive material or bear radioactive surface contamination.

Special Nuclec Materiol (SNM): Plutonium, uranium-233, uranium-235, or uranium enriched to a higher percentoge than normal of the 233 or 235 isotopes.

Tonks A large metal container located above ground or underground for storage of liquid wostes. 
Tak Fam: An installation of interconnected underground containers (tanks) for storoge of high-level waste.

Tronouranium Nuclides having an atomic number greater than that af uranium (i.e., greater than 92). The principal tronsuranic radionucl. . of concern in radiooctive waste monagement are tabulated below with their half-lives:

\begin{tabular}{lrl} 
Nuclide & $\begin{array}{r}\text { Half-Life } \\
\text { (Years) }\end{array}$ & \multicolumn{1}{c}{ Principgl Decoy Modes } \\
neptunium-237 & $2,140,000$ & alpho \\
plutonium-238 & 86 & alpha, spontaneous fission \\
plutonium-239 & 24,390 & alpha, spontaneous fission \\
plutonium-240 & 6,580 & alpha, spontaneous fission \\
plutonium-242 & 379,000 & alpho \\
americium-241 & 458 & alpho \\
americium-243 & 7,950 & ulpha \\
curium-245 & 9,300 & alpho \\
curium-24,6 & 5,500 & alpho, spontanesus fission
\end{tabular}

The transuranium nuclide produced in largest amounts is plutonium-239; americium-24l is also produced in significant amounts. One system of clossification used at Ock Ridge includes U-235 (162,000 year half-life, alpha decay) among the transuranium isotopes, althougi, strictly speoking this is not accurate.

Uroriums A radioactive element with the atomic number 92 and, as found in natural ores, on average atomic weight of opproximately 238 . The two principal natural isotopes are U-235 $(0.7$ percent of natural uranium), which is fissionable, and U-238 (99.3 percent of notural uranium), which is fertile. Natural uranium also includes a minute amount of U-234. 


\section{METRIC TO ENGLISH CONVERSION FACTORS}

To Obtain

Acres

Cubic Feet

Feet

Gallons

Inches

Miles

Pounds

Square. Feet

Tons (Short)

Temperature $\left({ }^{\circ} \mathrm{F}\right)$
Multiply

Hectares

Cubic Meters

Meters

Liters

Centimeters

Kilometers

Kilograms

Square Meters

Tons (Metric)

$\left({ }^{\circ} \mathrm{C}+17.78\right)$
By

2.471

35.314

3.281

0.2642

0.3937

0.6214

2.2046

10.764

1.1023

1.8 


\section{HANFORD RESERVATION}




\section{I.0 BACKGROUND ON HANFORD HIGH-LEVE WASTE MANAGEMENT}

The semiarid Hanford Reservation site occupies about 1,480 square kilometers of the southeastern part of the State of Washington. The reactor focilities are located olong the Columbio River in what is known os the 100 Areo. The reactor fuel processing and waste management facilities are in the 200 Area which is on a plateau about 11 kilometers from the river. The 300 Area, just north of Richland, contains the reactor fuel manufocturing focili es and the reseach and development laboratories.

In early 1943, the United States Army Corps of Engineers selected the Hanford site as the location for reactor and chemical separation facilities for the production and purification of plutonium for possible use in nuclear weapons (Manhattan Project). A total of eight grophite-moderated reactors using the Columbio River water for once-through cooling, and a new type of dual p.rpose reactor (NReactor) using o recirculating water coolent and producing tith plutonium and steam for electricity, were eventually built along the Columbia River. Today, only the N-Reactor remains in operation. 16

Defense high-level radioactive waste resulting from the chemical processing of spent nuclear fuel for recovery of plufonium, uranium and neptunium has been occumulated of the Honford Reservation since 1944. The waste containing most of the fission products and comparatively small quantities of uranium, plutonium and other actinides was originally stored as liquid in 149 undergrounu single-shell storage tonks. 15 This liquid contoins significant quantities of solids in the form of precipitated sludge. Begiming in 1958, problems were experienced with liquid leaking from some of these tanks. As a result, waste manogement activities since the 1960's have been primarily in the area of reduction of the volume of liquid waste by evaporation of the water to form on immobile solid (salt) and residual liquor. Residual liquor is the liquid formed from the currently used evcporated-crystallizer systems which upon additional concentration would form a hygroscopic solid unsuitable for storoge in single-shell tonks. The majority of the high-heat emitting radioisotopes, $5 \mathrm{r}-90$ and $\mathrm{C}_{5}-137$, is removed from the waste by means of a fractionization process which converts these isotopes to 
solid strontium fluoride and cesium chloride compounds which are then placed in double-walled capsules for storage in water basins. In addition to this activity, on additional waste-management program has been initiated to construct doubleshell tanks. All pumpable liquids will be stored in these high-integrity tanks by the early 1980's. No reactor-fuel reprocessing waste hos been accumulated since 1972 when the Purex Chemical Processing focility was last in operation. However this facility was scheduled to start up again in 1978 to process accumulated and future N-Reactor fuel. This has recently been indefinitely deloyed.

Upon completion of the current fractionization and solidification program in the early 1980's, defense high-level waste inventory will consist of opproximately:

- 95 million liters (bulk) of damp solt cake

- 41.6 million liters (bulk) of damp sludge

- $\quad 11.4$ million liters of liquid waste owaiting solidification

- 41.6 million liters of residual liquor

- 2900 capsules of $5 r-90$ and $\mathrm{Cs}-137$ 


\subsection{DESCRIPTION OF FACLITIES AND RADIOACTIVE WASTE NVENTORIES}

The DOE focilities of the Hanford Reservation include nuclear reactors for plutonium production (100 Area); fuels and plutonium processing and high- and low-activity rodioactive waste manogement (200 Area); fuel fabrication (300 Area); loborotory complex (300 Area); the Fost Flux Test Fucility (400 Area); central service facility (I100 Area); on-site construction services (3000 Area); and administrative services (700 Area).

Solid wastes contaminated with mixed fission and activation products have been disposed of by shallow land burial at the Hanford site since the beginning of operations in 1944. A total of 26 sites in the 100 Area ( 26 ho), 28 sites in the 200 Areo (68 ha), and II sites in the 300 and 600 Area (26 ha) hove been used for the storage and disposol of solid radioactive waste. ${ }^{17}$ Various facilities are discussed below.

\subsection{I00 AREA - REACTOR FACILITIES ${ }^{16}$}

The 100 Area contains:

- One operating reactor (N-Reactor)

- Eight retired or standby reactors

- Cribs rind burial grounds

All current wastes are shipped to the 200 Area for dispasal, however, $1.6 \times 10^{4}$ $\mathrm{mi}^{3}$ of solid waste was buried in the past as well as current N-Reactor primary coolant release to the $100-\mathrm{N}$ crib.

Detailed records were not kept in the past; however, total estimated input inventories of the reactor facilities through 1972 are: 
Radionuclide

Sr-90, Cs-137 and Pu-239

Eu-152 and Pu-239

Co-60

Fe-59 $\underline{\text { Ci }}$

160

650

76,100

150,000

Total estimated input inventories for crib and burial grounds through 1972 (except for 100-N Crib) are:

\author{
Radionuclide \\ Co-60 \\ Sr-90 \\ Pu-239 \\ $\mathrm{Zn}-65$ \\ $\mathrm{Mn}-54$ and $\mathrm{Zr}-95$
}

$\frac{C i}{1}$
25,900
34
0.38
1,000
3,500

Total estimated input inventories for the 100-N Crib through 1972 are:

\begin{tabular}{|c|c|}
\hline Radionuclide & $\underline{\mathrm{C}}$ \\
\hline $\begin{array}{l}\text { Co-60 } \\
\text { Sr-90 } \\
\text { Mn-54 and Zr-95 } \\
\text { Cs- } 137 \\
\text { All others }\end{array}$ & $\begin{array}{r}2,000 \\
50 \\
950 \\
350 \\
350\end{array}$ \\
\hline otal & 3,700 \\
\hline
\end{tabular}

A detailed discussion of the 100 Area is found in Reference 16.

\subsection{0-AREA REACTOR FUEL PROCESSING AND WASTE MANAGEMENT FACILITIES}

In addition to the fuel processing facilities the following waste disposal facilities receive waste trom all other Hanford areas, as well as outside agencies.

\subsubsection{TANKS (FOR HIGH-LEVEL WASTES)}

- 153 tanks (copacities from $1.89 \times 10^{5}$ liters is $3.79 \times 1 j^{6}$ liters each) 
- 3 tanks (under construction) for concentrated high temperature wastes

Table B-I lists the total tank waste inventory. Table B-2 gives the overage chemical composition of the high-level waste. Table B-3 gives the major fission products inventory and Table B-4 gives the major actinides inventory.

Figures B-1 and B-2 show the radionuclide content after 1990 of in-tank and encopsulated waste, respectively.

\subsubsection{CRIBS (FOR INTERMEDIATE LEVEL WASTES) ${ }^{15}$}

- 144 deactivated

- 8 not used

- 10 standby

- 15 currently in use

177 Total

Table B-5 gives the estimated irventories discharged to 200 Areo cribs and pands while Table B-6 gives the estimated inventory of plutonium at these sites.

\subsubsection{PONDS (FOR AUXILIARY PROCESS WATER) ${ }^{16}$}

- 30 ponds with total surface area of 145 hectares.

- 73 hectares in current use.

\subsubsection{SOLID RADIOACTIVE WASTE BURIAL GROUNDS ${ }^{16}$}

More than $1.42 \times 10^{5} \mathrm{~m}^{3}$ of contaminated solids have been buried on the 200 Area plateas since the start of chemical processing operations. These wastes consist of so-called "dry waste" (soiled clothing, laboratory supplies, tools, etc. packed in carboard, wood or metal containers) and industrial waste (primarily items of failed process equipment pockoged in heovy metal or concrete boxes). 
TABLE B-I

ESTIMATED HANFORD TANK WASTE INVENTORY 15

(In Millions of Liters)

New Tonks

Old Tanks

Total

1968

Liquid

181.7

49.2

230.9

Solid

56.8

3.8

60.6

1972

Liquid

177.9

3.8

181.7

Solid

79.5

2.6

82. 1

1976

Liquid

49.2

Solid

140

3.8

53

140

1980

Liquid

9.5

3.8

13.3

Solid

177.9

0

177.9 
TABLE B-2

\section{AVERAGE CHEMICAL COMPOSITION OF HANFORD HIGH-LEVEL WASTE}

\begin{tabular}{|c|c|c|c|c|}
\hline Chermical & $\begin{array}{l}\text { Salt } \\
\text { Coke } \\
\text { Wt.\% } \\
\end{array}$ & $\begin{array}{l}\text { Sludge } \\
\text { Wt.\% } \\
\end{array}$ & $\begin{array}{l}\text { Residual } \\
\text { Liquor } \\
\text { Wt. } \% \\
\end{array}$ & $\begin{array}{l}\text { Totai } \\
\text { Wt. \% } \\
\end{array}$ \\
\hline $\mathrm{NaNO}_{3}$ & $B 4.5$ & 17.2 & 12.1 & 50.9 \\
\hline $\mathrm{H}_{2} \mathrm{O}$ & 10.3 & 35.8 & 47.1 & 25.1 \\
\hline $\mathrm{Na}_{3} \mathrm{PO}_{4}$ & 0.1 & 22.6 & -- & 5.9 \\
\hline $\mathrm{NaOH}$ & 1.5 & 3.2 & 14.3 & 4.8 \\
\hline $\mathrm{NaNO}_{2}$ & 1.7 & 3.7 & 12.3 & 4.6 \\
\hline $\mathrm{NaAlO}_{2}$ & 1.4 & 3.1 & 11.7 & 4.1 \\
\hline $\mathrm{Na}_{2} \mathrm{CO}_{3}$ & 0.5 & 2.2 & 0.8 & 1.0 \\
\hline $\mathrm{Na}_{2} \mathrm{SiO}_{3}$ & -- & 2.9 & -- & 0.7 \\
\hline $\mathrm{Al}_{2} \mathrm{O}_{3}$ & .. & 2.3 & -- & 0.6 \\
\hline $\mathrm{Fe}(\mathrm{OH})_{3}$ & -- & 1.8 & -- & 0.5 \\
\hline $\mathrm{No}_{2} \mathrm{SO}_{4}$ & .. & 1.1 & 0.5 & 0.4 \\
\hline Other & $\cdots$ & 4.1 & 1.2 & 1.4 \\
\hline TOTALS & 100.0 & 100.0 & 100.0 & 100.0 \\
\hline
\end{tabular}

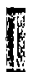

1

1

I

I!

㹂

Solt

Wt. \%

84.5

10.3

0.1

1.5

1.7

1.4

100.0

100.0

100.0

Residual

Wt. \%

50.9

5.1

5.9

4.8

4.6

4.1

.0

0.7

0.6

0.5

0.4

1.4

100.0 


\section{TABLE B-3}

INVENTORY OF MAJOR FISSION PRODUCTS IN HANFORD HIGH-LEVEL WASTE DECAYED TO $(290$

(FROM REACTOR PRODUCTION - 1944-1971)

(Curies)

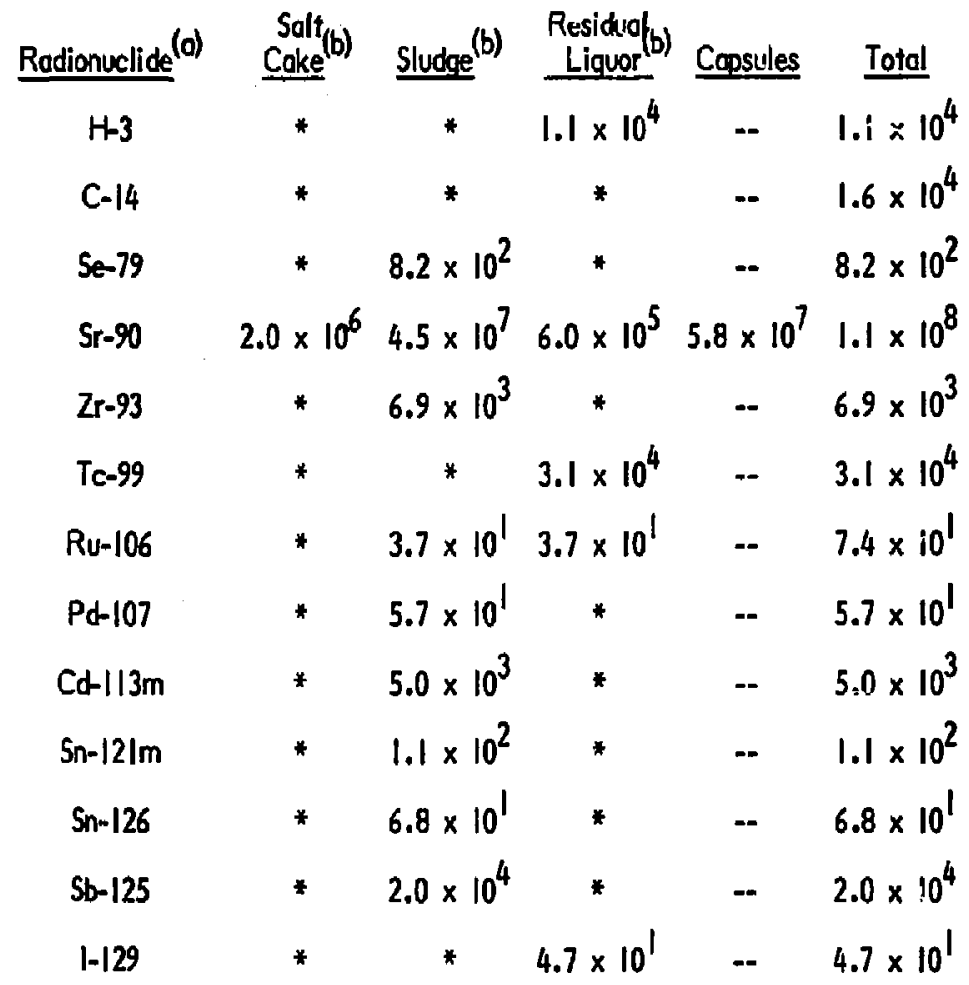

Cs-134 $1.2 \times 10^{2} 1.2 \times 10^{2} 4.3 \times 10^{2} 2.5 \times 10^{3} 3.2 \times 10^{3}$

Cs-135 $4.4 \times 10^{1} 4.4 \times 10^{1} 1.6 \times 10^{2} 9.0 \times 10^{2} \quad 1.1 \times 10^{3}$

Cs-137 $5.0 \times 10^{6} 5.0 \times 10^{6} 1.8 \times 10^{7} 1.0 \times 10^{8} \quad 1.3 \times 10^{8}$

Ce-144 $\quad * \quad 9.9 \times 10^{0} \quad * \quad--9.9 \times 10^{0}$

$P_{\mathrm{m}-147} \quad * \quad 1.0 \times 10^{6} \quad * \quad--1.0 \times 10^{6}$

Sm-151 * $\quad 1.4 \times 10^{6} \quad * \quad--\quad 1.4 \times 10^{6}$

Eu-152 * $1.5 \times 10^{3} \quad * \quad=1.5 \times 10^{3}$

Eu-154 * $7.3 \times 10^{4} \quad * \quad \quad-7.3 \times 10^{4}$

Eu-155 * $7.4 \times 10^{4} * * \quad=7.4 \times 10^{4}$

(a) Doughter nuclides in decay chains are not listed.

Curie values are fer porent nuclide only.

(b) Rodionuclides present in trace quantities are indicoted by on asterisk. 
TABLE B-4

INVENTORY OF MAJOR ACTINIDES IN HANFORD HIGH-LEVEL WASTE DECAYED TO 1990 (FROM REACTOR PRODUCTION - 1944-1971)

(Curies)

\begin{tabular}{cc} 
Radionuclide $^{(a)}$ & Sludge \\
\hline$U-233$ & $4.0 \times 10^{2}$ \\
U-235 & $1.3 \times 10^{1}$ \\
U-238 & $3.0 \times 10^{2}$ \\
Np-237 & $1.0 \times 10^{2}$ \\
Pu-238 & $4.0 \times 10^{2}$ \\
Pu-239 & $2.1 \times 10^{4}$ \\
Pu-240 & $5.2 \times 10^{3}$ \\
Pu-241 & $6.0 \times 10^{4}$ \\
Am-241 & $5.0 \times 10^{4}$
\end{tabular}

a. Salt cake and reșidual liquor contain trace quantities of these isotopes (see Table B-3). 


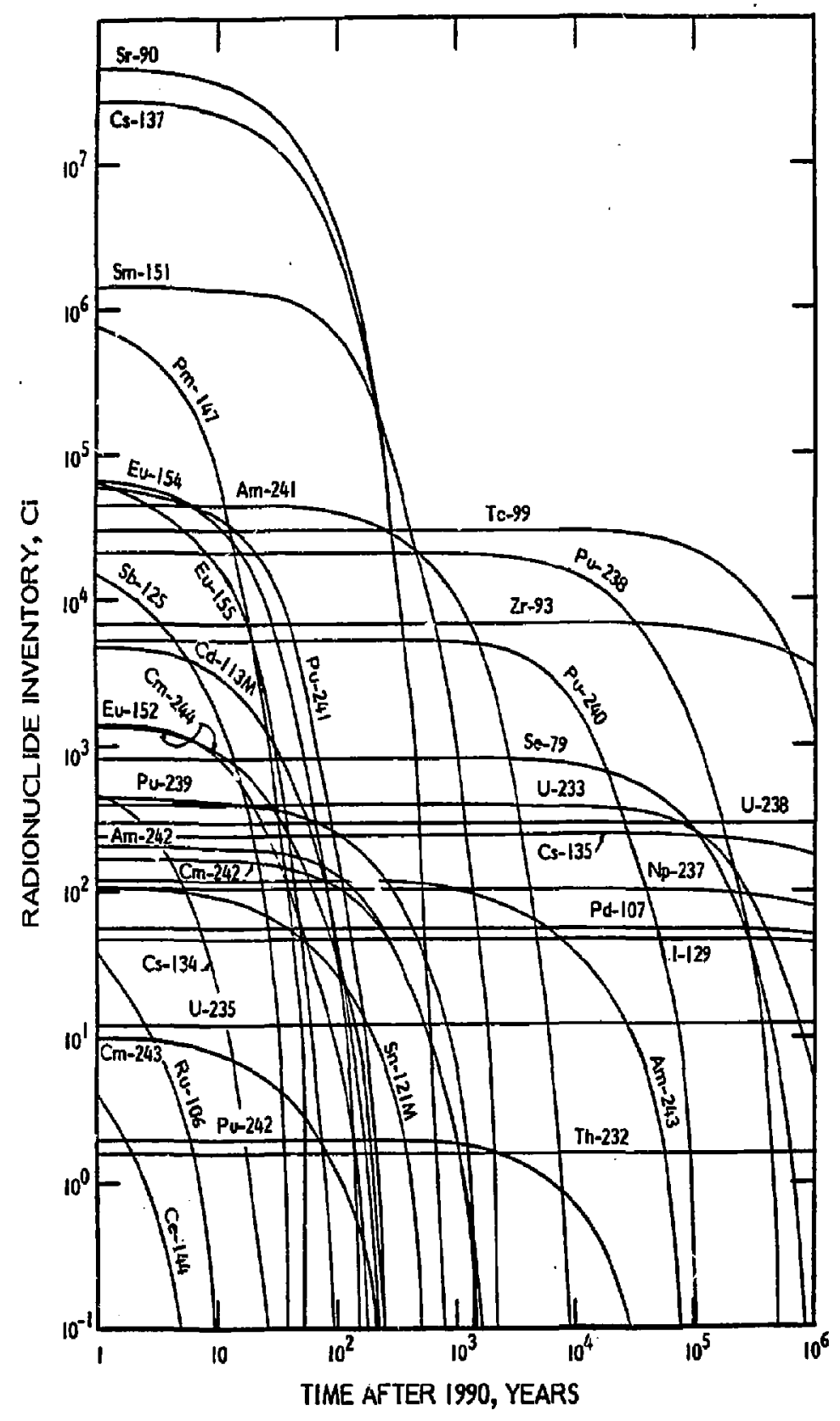

FIGURE B-I

RADIONUCLIDE CONTENT OF HANFORD IN-TANK WASTE ${ }^{15}$ 
TABLE B-5

ESTIMATED INVENTORIES ${ }^{(0)}$ RADIOACTIVE LIQUID WASTE
TO GROUND 200 AREAS

$\underline{\text { Units }} \begin{gathered}\begin{array}{c}\text { ToPonds } \\ \text { ondDitches }\end{array} \\ \begin{array}{c}\text { To } \\ \text { Cribs }\end{array}\end{gathered} \begin{gathered}\text { To Specific } \\ \text { Retention Sites }\end{gathered}$ Totol $^{(\mathrm{b})}$

Decay Through 1972 (From Startup) 200 East

$\begin{array}{lcrrrr}\text { Volume } & \text { (I) } & 3.0 \times 10^{11} & 2.0 \times 10^{10} & 1.0 \times 10^{8} & 3.0 \times 10^{11} \\ \text { Pu } & (\mathrm{g}) & <7.0 \times 10^{2} & 1.0 \times 10^{4} & 4.0 \times 10^{2} & 1.0 \times 10^{4} \\ \text { Beto } & (\mathrm{Ci}) & 6.0 \times 10^{3} & 6.0 \times 10^{4} & 4.0 \times 10^{4} & 1.0 \times 10^{5} \\ \text { Sr-90 } & (\mathrm{Ci}) & 1.0 \times 10^{3} & 1.0 \times 10^{4} & 8.0 \times 10^{3} & 2.0 \times 10^{4} \\ \text { Ru-106 } & (\mathrm{Ci}) & <3.0 \times 10^{1} & 2.0 \times 10^{3} & 3.0 \times 10^{2} & 3.0 \times 10^{3} \\ \text { Cs-137 } & (\mathrm{Ci}) & 4.0 \times 10^{2} & 8.0 \times 10^{3} & 1.0 \times 10^{4} & 2.0 \times 10^{4} \\ \text { Co-60 } & (\mathrm{Ci}) & <3.0 \times 10^{1} & 1.0 \times 10^{2} & 2.0 \times 10^{1} & <2.0 \times 10^{2} \\ \dot{U} & (\mathrm{~kg}) & <1.0 \times 10^{4} & 3.0 \times 10^{4} & 5.0 \times 10^{4} & 8.0 \times 10^{4} \\ \text { U-233 } & (\mathrm{g}) & <5.0 \times 10^{2} & 5.0 \times 10^{2} & & <1.0 \times 10^{4}\end{array}$

Decoyed Through 1972 (From Startup) 200 West

$\begin{array}{lllllll}\text { Volume } & \text { (1) } & 2.0 \times 10^{11} & 1.0 \times 10^{10} & 8.0 \times 10^{7} & 2.0 \times 10^{11} \\ \text { Pu } & \text { (g) } & 8.0 \times 10^{3} & 8.0 \times 10^{4} & 9.0 \times 10^{4} & 2.0 \times 10^{5} \\ \text { Beto } & \text { (Ci) } & 4.0 \times 10^{2} & 3.0 \times 10^{4} & 2.0 \times 10^{4} & 5.0 \times 10^{4} \\ \text { Sr-90 } & \text { (Ci) } & <1.0 \times 10^{2} & 6.0 \times 10^{3} & 2.0 \times 10^{2} & 7.0 \times 10^{3} \\ \text { Ru-106 } & \text { (Ci) } & <2.0 \times 10^{0} & 9.0 \times 10^{1} & 2.0 \times 10^{0} & 9.0 \times 10^{1} \\ \text { Cs-137 } & \text { (Ci) } & <9.0 \times 10^{1} & 5.0 \times 10^{3} & 1.0 \times 10^{4} & 2.0 \times 10^{4} \\ \text { Co-60 } & \text { (Ci) } & <9.0 \times 10^{0} & 3.0 \times 10^{1} & 3.0 \times 10^{0} & <4.0 \times 10^{1} \\ \text { U } & \text { (kg) } & <6.0 \times 10^{3} & 4.0 \times 10^{4} & 1.0 \times 10^{3} & 4.0 \times 10^{4}\end{array}$

(a) The estimated inventories (or concentrations) of radionuclides are reported to one significont figure to reflect the uncertainty in the dato. Where the estimated inventories are noted as less than ( < ), the recorded inventory is bosed on the analytical limit of detection.

(b) Totals do not necessarily equal the sum of individual contributions because of rounding of the dato. 


\section{TABLE B-5}

\section{(CONT.)}

$\underline{\text { Units }} \begin{gathered}\text { ToPonds } \\ \text { ondDitches }\end{gathered} \begin{gathered}\text { To } \\ \text { Cribs }\end{gathered} \begin{gathered}\text { To Specific } \\ \text { Retention Sites }\end{gathered}$ Total $^{(b)}$

Decoyed Through 1972 (From Startup) Total 200-E + 200-W

$\begin{array}{lrrrrrr}\text { Volume } & \text { (I) } & 5.0 \times 10^{11} & 3.0 \times 10^{11} & 2.0 \times 10^{8} & 5.0 \times 10^{11} \\ \text { Pu } & \text { (g) } & 9.0 \times 10^{4} & 9.0 \times 10^{4} & 9.0 \times 10^{4} & 2.0 \times 10^{5} \\ \text { Beto } & \text { (Ci) } & 7.0 \times 10^{3} & 9.0 \times 10^{4} & 6.0 \times 10^{4} & 2.0 \times 10^{5} \\ \text { Sr-90 } & \text { (Ci) } & 2.0 \times 10^{3} & 2.0 \times 10^{4} & 8.0 \times 10^{3} & 3.0 \times 10^{4} \\ \text { Ru-106 } & \text { (Ci) } & <3.0 \times 10^{1} & 2.0 \times 10^{3} & 3.0 \times 10^{2} & 3.0 \times 10^{3} \\ \text { Cs-137 } & \text { (Ci) } & 5.0 \times 10^{2} & 1.0 \times 10^{4} & 2.0 \times 10^{4} & 4.0 \times 10^{4} \\ \text { Co-60 } & \text { (Ci) } & <4.0 \times 10^{1} & <2.0 \times 10^{2} & 2.0 \times 10^{4} & <2.0 \times 10^{2} \\ \text { U } & \text { (kg) } & <7.0 \times 10^{3} & 6.0 \times 10^{4} & 5.0 \times 10^{4} & 1.0 \times 10^{5} \\ \text { U-233 } & \text { (g) } & <5.0 \times 10^{2} & 5.0 \times 10^{2} & & <1.0 \times 10^{3}\end{array}$

(a) The estimated inventories (or concentrations) of radionuclides are reported to one significant figure to reflect the uncertainty in the dato. Where the estimated inventories are noted as less than $(<)$, the recorded inventory is bosed on the onalytical limit of detection.

(b) Totals do not necessarily equal the sum of individual contributions because of rounding of the dato. 
TABLE B-6

ESTIMATED INVENTORIES OF PLUTONIUM IN DISPOSAL SITES ${ }^{16}$

Disposal Site

Plutonium Plutonium

216-U-10

$\cup$ Pond and Ditches

8.3

$216-Z-3$

5.7

I

216-B-7

224-B, 221-B, 5-6 Cell and

Construction Waste

(kg) Disposal Site $(\mathrm{kg})$

216-S-! and -2

Redox Process Condensate

216-T-32

224-T Waste

216-Z-IAA

$216-Z-\mid A B$

216-Z-IAC

$216-Z-1$ and 2

$3.2 \quad 216-Z-9^{(r)} \quad 38 .^{(b)}$

$216-Z-4 \quad 0.002$

4.3

216-Z-5

0.34

216-Z-6 $\quad 0.005$

$1.2 \quad 216-2-7 \quad 2.0$

30.

$216-Z \cdot 10 \quad 0.05$

17. $216-Z-12 \quad 25$.

II. $216-Z-16 \quad 0.07$

7.0

$216-Z-17 \quad 0.05$

$216-Z-18 \quad 22$.

(a) "Z-9" Crib.

(b) Other estimates indicate that the system to contain between 25 and 70 kilograms of plutonium. 
Transuranic bearing woste has been packaged in sealed metal containers and segregated in the burial trenches since May 1970. Contaminated solid waste is buried in 19 sites on the 200 Area plateou using 63 hectares. Some failed equipment from the Purex Facility is stored in tunnels on flat cars.

Prior to 1968, essentially all of the waste buried was generated by the 200 Area operating facilities. Since 1968, waste generated by 300 Areo operations alsc nas been buried in the 200 Areo sites. Beginning in December 1973, waste irom reactor operations in the 100 Area was being sent to the 200 Area for burial. Small volumes of solid waste, generoted by offsite DOE operotions, have been and will continue to be buried here. During 1973, approximately $60 \mathrm{~m}^{3}$ containing less thon $4 \mathrm{Ci}$ of mixed radioactive materials were received from offsite.

Tables B-7 and B-8 give the estimated inventories of the burial grounds and Purex storoge tunnels, respectively.

The dry wastes listed in Table B-7 have been characterized and are presented in Table B-9.

\subsection{AREA - REACTOR FUEL MANUFACTURING FACILITIES AND RESEARCH AND DEVELOPMENT LABORATORIES}

There is a $2.84 \times 10^{5}$ liter copacity temporary storage facility in the 300 Area; however, all liquid wastes ore currently iransferred to the 200 Area for ultimate disposal.

Currently generoted solid woste is sent to the 200 Area burial ground; however between 1944 and 1967 epproximately $2.1 \times 10^{4} \mathrm{~m}^{3}$ were buried in the 300 Area. It is estimated that this buried waste contained $10 \mathrm{Ci}$ of uranium contamination and $0.5 \mathrm{Ci}$ of thorium contamination.

Three contractors are conducting research and development studies in the area: Westinghouse-Hanford, Battelle-Northwest, and United Nuclear Industries. ${ }^{19}$ 
TABLE Q-

ESTIMATED DECAYED STATUS OF SOLID WASTE ${ }^{(0)}$ DURIAL GROUNAS IN THE ZO0 AREAS THROUGH 1972 16

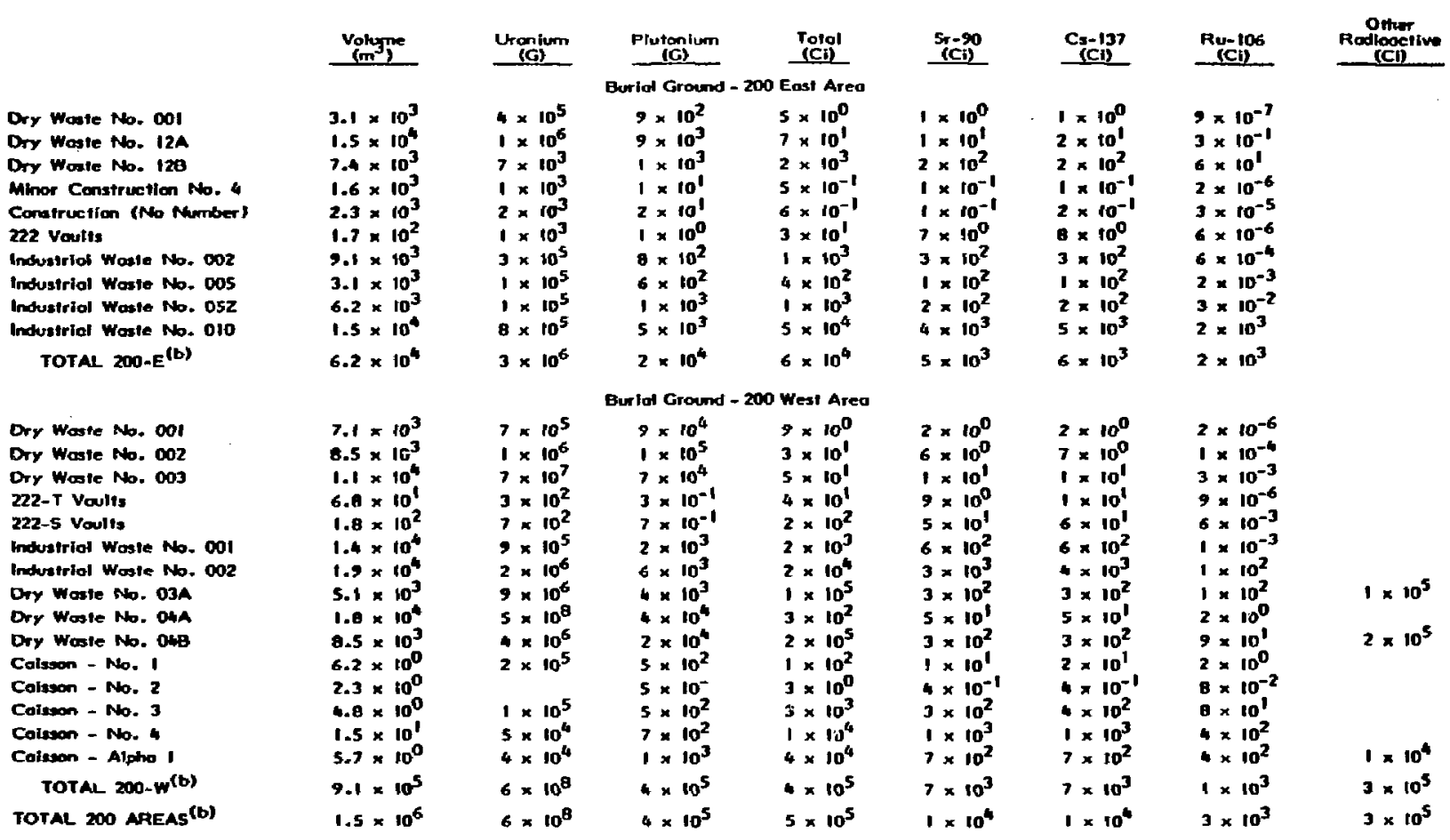

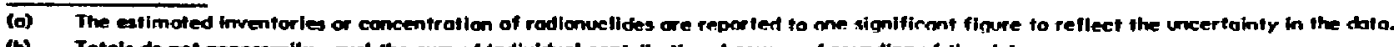

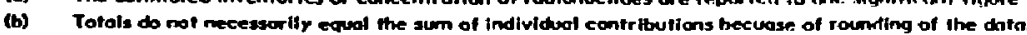


TABLE B-8

PUREX EQUIPMENT STORAGE TUNNELS $S^{(a)}$ INVENTORY ${ }^{(b}$ r SEPTEMBER 30, $1973^{16}$

\begin{tabular}{crr} 
Tunnel No. I & & Tunnel No. 2 \\
\hline 566 & & Total $^{(c, d)}$ \\
6,000 & 566 & 1,133 \\
1,000 & 20,000 & 30,000 \\
1 & 40 & 1,000 \\
1,000 & 7 & 8 \\
-- & 20,000 & 20,000 \\
- & 500 & 500
\end{tabular}

Volume, $\mathrm{m}^{3}$

Total MFP, $C i^{(d)}$

$\mathrm{Sr}-90, \mathrm{Ci}$

Ru-106, Ci

Cs-137, $\mathrm{Ci}$

$\mathrm{Co}-60, \mathrm{Ci}$

Pu-239, g

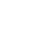

$\frac{\text { Tunnel No }}{566}$
(a) Currently the distribution of waste plutonium stored on the Hanford site is 40 percent in tanks, 39 percent in solid disposal sites and 21 percent in liquid disposal sites. The total amount of plutonium in these sites is estimated to be $940 \mathrm{~kg} \pm 30$ percent.

(b) The estimated inventories (or concentrations) of radionuclides are reported to one significant figure to reflect the uncertainty in the data.
(c) Totals do not necessarily equal the sum of individual contributions because of rounding of the data.

(d) Curies shown are decayed to September 30, 1973. 
TABLE B-9

CHARACTERISTICS OF DRY WASTE BURIED ${ }^{16}$

ON AN AVERAGE DAY (MAXIMUM) ${ }^{5}$

\begin{tabular}{|c|c|c|c|c|}
\hline Source & No. & Container & $\begin{array}{c}\text { Volunge } \\
\left(\mathrm{ft}^{3}\right)\end{array}$ & Activity, $\mathrm{Ci}$ \\
\hline \multirow{2}{*}{$\begin{array}{l}\text { 222-S Bldg. } \\
\text { (Hot cell) }\end{array}$} & $4(5)$ & 30-gal & $30(38)$ & $20 .(70)+._{.}^{(o)}$ \\
\hline & $g(22)$ & Cardboard boxes & $40(100)$ & $0,6(3) F . P$ \\
\hline $221=\mathrm{T}$ & $14(22)$ & Cardboard boxes & $60(100)$ & \\
\hline Loundry & $9(22)$ & Cardboard boxes & $40(100)$ & $0.1(2) F . P$. \\
\hline Misc. & $5(22)$ & Cardboard boxes & $20(100)$ & \\
\hline BNW & $70(150)$ & Cardbeard boxes & $300(700)$ & \\
\hline HEDL & $45(75)$ & Cardboard boxes & $200(300)$ & \\
\hline
\end{tabular}

(a) Fission Products

* ( ) designate maximum daily volume. 
The TRU waste shipments during the first half of CY-1976 are presented in Table B-10. The volumes and their TRU content are reported for combustible and noncombustible wastes. For the first holf of $C Y-1976,16.1 \mathrm{~m}^{3}$ of combustible waste and $7.4 \mathrm{~m}^{3}$ of noncombustible waste were shipped for disposal. This compares with the first half $C Y-1975$ shipments of $40.7 \mathrm{~m}^{3}$ containing 1,344 grams of plutonium.

\subsection{AREA - FAST FLUX TEST FAC!LITY (FFTF)}

This is a construction areo and no radiocctive wastes are presently being generoted.

\subsection{AREA $^{16}$}

The 600 Area is all other Hanford Reservation areas not included in the 10n, 200, 300 or 400 Areas. In the past miscellaneous low-level solid radioactive wostes may have been buried in this area; however, accurate records were not kept and volumes and composition are not known. 
TABLE B-10

TRU WASTE SHIPMENTS

FROM 3/10 AREA TO 200 AREA (I/76-6/76)

Average Total

Weight Volume

1

Function

No. of Drums ${ }^{(a)}$

k. $\mathrm{m}^{3}$

Pu Content

Combustible Waste

Quality Control

25

$\begin{array}{lll}59 & 5.30 & 203\end{array}$

Fuel Fabrication

22

54

4.66

167

Post Irradiation

27

54

5.73 N.A. ${ }^{(c)}$

Testing

Maintenance

2

$80 \quad 0.42$

2.6

and Miscelloneous

$\overline{76}$

$\overline{57} \quad \overline{16.11}$

373

Noncombustible

Waste $^{(b)}$

2 Steel

N.A. ${ }^{(c)} 1.36$ N.A. $^{(c)}$

boxes

Total

$23.5 \quad 373$
(a) $0.2 \mathrm{~m}^{3}$ drums
(b) Packoges waste - obsolete equipment, concreted dum waste, etc.
(c) Not assoyed due to high $\beta-\gamma$ activity. 


\subsection{LIGUID WASTES ${ }^{16}$}

Approximately $1.44 \times 10^{8}$ liters of liquid woste and $9.46 \times 10^{7}$ liters of solidified waste (as of March 1975) are currently stored in underground tanks at Hanford. This waste was generated during the period 1944 to 1974 and represents more than 95 percent of the total high-level waste expected to be generated during the operation period of the Hanford plutonium production facilities through 1978. Based on current production plans, the operation of N-Reactor and the Purex Processing Plant results in the generation of approximately 3.8 million liters of high-level waste each year. Operation of these facilities through 1983 or 1990 will generate about $1.9 \times 10^{7}$ or $4.5 \times 10^{7}$ liters of additional high-level liquid nuste, respectively. This liquid would be converted to $3.8 \times 10^{6}$ to $1.1 \times 10^{7}$ liters of solidified waste,

The thrust of the current waste management program for high-level waste is to convert stored and currently generated high-level waste from a liquid to a salt cake form. The existing evoporotors, along with one evaporator currentiy under construction (1972), will solidify most of the stored and currently generated liquid waste to salt cake. A residuum of highly caustic liquid will remain which cannot be further evoporated with these evoporotors. The residuum will be treated to produce a solid either by chemical addition or a special type evaporator, alternatives which are now under development. If a sutisfactory solidified woste (immobile but removable) cannot be developed for interim storage at a reasonable cost, then the residuum could conitinue to be stored in double-wall tanks until on ultimate disposal method is in place. Replacement tanks could be built from time to time as needed to continue storoge of this liquid. Since any leakoge from the primary tank can be collected, detected and removed by pumping from the secondary tank, leakage of liquid waste to the soil would be effectively eliminated.

The solidification of the liquid waste, along with the construction of additional double-wall tonks to contain the liquids in interim periods, is considered to be the current progrom for monagement of the high-level woste. 


\subsection{SOLID WASTES}

\section{I OVERVIEW}

More than $1.42 \times 10^{5} \mathrm{~m}^{3}$ of contaminated solids have been buried on the 200 Area plateou since the start of chemical processing operations. These wastes consist of so-called "dry woste" (soiled clothing, loboratory supplies, tools, etc., packed in carboard, wood or metal containers) and industrial waste (primarily items of failed process equipment packaged in sealed metal containers) and segregated in the burial trenches since May 1970. Contaminated solid waste is buried in 19 sites on the 200 Area plateau using 63 hectares. Some failed equipment from the Purex Facility is stored in tunnels on flat cars. A summary of all solid waste volume is given in Table B-II.

A review of the distribution of waste by cotegories defined based on plutonium concentration and general radiation levels, indicates that the waste in the 200 Area is generally low radiation level boxed dry waste. Tables B-12 and B-13 present this information based upon Reference 18. It would appear that similar ratios would be cppropriate for the present iriventory of the 200 Area.

Solid radioactive waste buried in the ground is considered to be in long-term storage. An exception is that waste buried after April 30, 1970, which is suspected of containing transuranium nuclides; this is considered to be in interim storage (20 years). Large items of solid waste, such as failed equipment from locations where the presence of transuranium nuclides can be sofely ruled out, are packaged in concrete boxes and buried in industrial waste burial trenches. Small items of failed equipment and trash-type contaminated waste, from locations where the presence of transuranium nuclides con be safely ruled out, are packaged in cardboard cartons, wood boxes, or steel or fiber drums and buried in the so-cailed "dry waste" tivenches.

The various waste containers used provide contoinment of nontronsuranic radioactive contamination and minimize radiation exposure to personnel during temporary storage, handling, shipment, and burial operations. Once buried, no reliability is placed on the containers for confinement or retrievability of these 


\section{TABLE 3-II}

SUMMARY SOLID RADIOACTIVE WASTE RELEASES TO THE GROUND ${ }^{16}$

\begin{tabular}{|c|c|c|c|c|}
\hline \multirow{2}{*}{\multicolumn{2}{|c|}{$\begin{array}{c}\text { Waste } \\
\text { Ceneration }\end{array}$}} & & \multirow[b]{2}{*}{$\begin{array}{c}\text { Current } \\
\text { Disposition } \\
\text { Location }\end{array}$} \\
\hline & & $\begin{array}{c}\text { Currently } \\
\text { Stored } \\
\left(\mathrm{m}^{3}\right) \\
\end{array}$ & $\begin{array}{c}\text { Future } \\
\text { Storage } \\
\left(\mathrm{m}^{3} / \mathrm{yr}^{(\mathrm{a})}\right. \\
\end{array}$ & \\
\hline 100 Areo & $\begin{array}{l}\text { Misceflaneous solid } \\
\text { wasie }\end{array}$ & $1.6 \times 10^{4}$ & 1,130 & 200 Areas \\
\hline 200 Areo & $\begin{array}{l}\text { Miscellaneous solid } \\
\text { woste }\end{array}$ & $1.6 \times 10^{5}$ & 2,600 & 200 Areas \\
\hline 300 Area & $\begin{array}{l}\text { Miscelloneous solid } \\
\text { waste from fuel } \\
\text { element monufacturing } \\
\text { containing uronium } \\
\text { and thorium and } \\
\text { from research and } \\
\text { development }\end{array}$ & $2.1 \times 10^{4}$ & 1,590 & 200 Areas \\
\hline 600 Area & $\begin{array}{l}\text { Miscelloneous solid } \\
\text { waste }\end{array}$ & (b) & 0 & 200 Areos \\
\hline
\end{tabular}

(a) All future solid waste sent to the 200 Area,

(b) Volume not known. 
TABLE B-12

\section{ESTIMATED VOLUMES OF BURIED TRANSURANIIJM SOLID WASTE AT HANFORD 200 AREA BURIAL GROUNDS THROUGH $1969^{\circ}$}

\begin{tabular}{|c|c|c|c|c|c|}
\hline \multicolumn{2}{|r|}{ Type } & $\begin{array}{l}\text { Surface } \\
\text { Dose Rote } \\
\text { (mrem/hr) }\end{array}$ & $\begin{array}{c}\mathrm{Pu}^{\mathrm{a}} \\
\text { Content } \\
\text { (kg) } \\
\end{array}$ & $\begin{array}{l}\text { Beto Activity } \\
\text { As Charged } \\
\text { (Ci) }\end{array}$ & $\begin{array}{c}\text { Volume } \\
\text { As Charged } \\
\left(\mathrm{m}^{3}\right) \\
\end{array}$ \\
\hline I. & $\begin{array}{l}\text { Low radiotion level, } \\
\text { boxed dry waste }\end{array}$ & $<10$ & 298 & 2,000 & 48,100 \\
\hline 2. & $\begin{array}{l}\text { High radiation level, } \\
\text { boxed dry waste }\end{array}$ & $>10$ & 34 & 8,000 & 19,800 \\
\hline 3. & $\begin{array}{l}\text { Foiled metal equip- } \\
\text { ment (boxed or bagged) }\end{array}$ & $>10$ & 23 & 620,000 & 70,750 \\
\hline & Total & & 355 & 630,000 & 138,650 \\
\hline & $\begin{array}{l}\text { large equipment in } \\
\text { Purex rail tumels }\end{array}$ & 31,000 & $>1$ & $>10,000$ & 1,550 \\
\hline & $\begin{array}{l}\text { and surrounding soil } \\
\text { with } \mathrm{Pu} \leq 2 \mathrm{C} \mathrm{Ci} / \mathrm{kg}\end{array}$ & $<10$ & 260 & $3,100,000$ & \\
\hline
\end{tabular}

a Plutonium in use at Hanford typically is $94 \%$ Pu-239 and $6 \%$ Pu-240 and has specific alpha activity of $0.07 \mathrm{Ci} / \mathrm{g}$ of the element. 
TABLE B-13

ESTIMATED SOLID WASTE BURIALS W HANFORO 200 AREAS DURING CY $1969^{10}$

1. Pu confominated, low rodiation levifl boxed dry wote

2. Pu confominoted intermedlate rodifation level,

3. Pu contaminoted, high rodiation legel.

4. Foiled metal equipment, high radiation level

5. Low transuronic low radiation level,

6. Low transurante, high radiation lexel. boxed dry waste

Total

\section{Percent \\ Burnoble}

75

75

50

10

\section{Surfoce \\ (mrem/hr)}

$<2$

$10-100$

$>100$

$>10$

$<10$

$>10$
Total

Pu

(a)

4,000

500

400

200
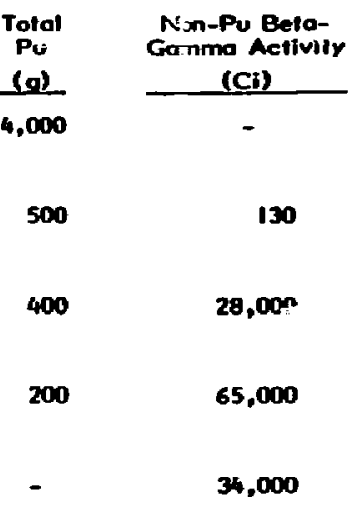

$-$
130

28,000

65,000

34,000

$680^{d}$

40,000

1.700

Toral

Volume

$790^{\circ}$

630

1,130

540

168,000

$5,470^{\circ}$

a Waste in cardboard boxes, wood boxes, and metal drums consists of cloth, poper, plastic, lools, glass filiers, dirt, and miscelloneous small hordwore.

b Consists primarily of failed tnetal equipment in wood or concrete boxes.

C Includes $70 \mathrm{~m}^{3}$ from Rocky Flots.

d Includes $42 \mathrm{~m}^{3}$ from Lawence Radiolion Labor aiory.

- Total volumes were $4,300 \mathrm{~m}^{3}$ in 1967 ind $4,950 \mathrm{~m}^{3}$ in 1968. 
materials. Although burial of the waste containers by bockfilling the trerich is normaliy done at the close of the day's receipt of solid woste, waste trenches are immediately backfilled whenever the dose rate at the edge of the trench reaches $100 \mathrm{mP} / \mathrm{hr}$. Solid waste is normally covered with three to six meters of earth to prevent uptake of rodionuclides by plant life or disturbance by burrowing onimals. An exception, waste contained in concrete boxes or small drums, may hove o minimum dirt cover of four feet provided that radiation levels at grade are less than $1 \mathrm{mR} / \mathrm{hr}$. Periodic routine surveillance of filled burial trenches is provided to assure that the burial grounds are maintained to meet existing stondards.

Solid woste, containing or suspected of containing transuranium nuclides cbove $10 \mathrm{nCi} / \mathrm{g}$ buried after April 30, 1970, is packaged and buried in compliance with DOEM-0511. This directive states that "such wastes shall be segregated from other solid wastes and shall be packaged and buried so that they can be readily retrievable, as contamination-free packages, within an interim period of $\mathbf{2 0}$ years."

Formerly, the waste was packaged in steel dums and steel or concrete boxes and buried in special trenches. Subsequent evaluotion of steel drums directly buried in Hanford soils indicated that failures could occur in less thon 20 years and retrieval, as contamination-free packages, might not be passible. Two alternatives to direct burial were implemented on a test basis, either of which will protect the containers from direct contect with the soil and will permit ease of retrieval. One method consists of stacking steel drums on a pad and covering with plywood and nylon sheeting prior to covering with four feet of earth. The other method is placing the trums in a concrete "vee" trench, placing a metal cover over the top and covering with earth.

Small items of transuranic-bearing solid waste, containing fission products copable of generating high dose rate gamma emissions, are packaged and shipped in shielded casks. This waste is dischorged from the casks to cuissons, which con be retrieved. 
Some of the Purex frccessing equipment is so large and becomes so contaminated in service, that its trensport to a burial ground would require obnormally high exposure of operating personnel. Such equipment is placed on flatciors and pushed into the solid waste storage tunnels appended to the Purex Plant.

\subsection{TRU BURIAL FACILITIES ${ }^{16,18}$}

Asphalt pads ore currently being used for the retrievole storoge of low-nctivity TRU wastes, The wastes are packaged in 208-1 drums or in steel boxes and stacked on the pod in 7.3-m wide $\times 7.3$ m-high modules. Flame-retardant plywood is placed between the loyers, and plywood is placed on top of the modules. The completed module is covered with PVC laminoted nylon sheet and I.3 m of soil overburden. TRU waste generated between June 1972 and March 1973 was placed in 208-1 drums and stored in a concrete "vee" trench. Waste drums were placed at a $45^{\circ}$ angle inside the trench. A steel cover was then placed over the trench and covered with $1.2 \mathrm{~m}$ of soil as an overburden.

Underground caissons are used for storage of small packoges of high-activity TRU waste. The woste is packoged in 3.8-1 or 18.9-1 point cons with clips or resin to hold the lids in place. The caissons are reinforced concrete cylinders buried $4.0 \mathrm{~m}$ below the surface. The caissons have $0.9-\mathrm{m}$-diameter chutes, offset or convoluted to reduce surface rodiation exposure.

Extrenely large, heavy, or highly contominated waste equipment is stored on railroad flat cars in two railroad tunnels. The contamination moy be TRU or non-TRU and is usually ossociated with activation products. One tunnel is filled with eight flat cars and is now inactive. The second tunnel is $515 \mathrm{~m}$ long and con store chout 42 flat cars. At present (1977), nine cors of waste are stored in this tunnel. 18

TRU waste unsuitable for pad or caisson storage due to size, secur ity requirements, or surface radiation is stored in alpha trenches. This waste is packaged in fiberglass-reinforced polyester-covered plywood boxes, reinforced concrete boxes, metal boxes, or 208-1 dums. Once placed in the trench, the waste is 
covered with I meter of soil. These trenches are also used for storage of TRU and non-TRU classified waste in 208-I drums, The drums are stacked vertically and covered with a plywood cover. Completely filled trenches are covered with a PVC laminated nylon sheet and $1.2 \mathrm{~m}$ of soil. Classified wastes are covered on the day they are placed in the trenches.

Currently used packaging for racioactive wastes ranges from carboard boxes sealed with tope to flonged steel containers with reinforced concrete shielding.

The fissile content of each container accepted for burial is measured before or subsequent to packaging, and the amount of fissile material is recorded on the shipping popers. All of the wastes are monitored for surface contamination at their point of origin. Dose rates at the surface of a package are determined and recorded. All packages must be free from external contamination. Generally, radiation rates of the surface of a package are less than $10 \mathrm{mR} / \mathrm{hr}$. Highactivity wastes are transported in shielded metal containers.

The accumulated volume of radioactive waste at Hanford is approximately $188,000 \mathrm{~m}^{3}$, which contains $2,039 \mathrm{KCi}$ of radioactivity. 
1

1

$I$

$\amalg$

1

11

$\bigsqcup$

APPENDIX C

IDAHO NATIONAL ENGINEERING LABORATORIES (INEL)

非

II

1

$I$

5

E

1

I 


\subsection{BACKCROUND 22,21}

The Idaho National Engineering Laboratory (INEL), formerly named the National Reoctor Testing Station, was established in 1949 as an area where nucleor reactors, support plants, and equipment could be constructed, tested, and operated. The INEL covers an orea of about $2,300 \mathrm{~km}^{2}$ on the central edge of the semiarid Snake River Plain. Since 1949, 51 nuclear facilities, mostly reactors, have been built, or are under construction or design at the INEL. These facilities include the Idaho Chemical Processing Plont (ICPP), which reprocesses irrodioted spent nuclear fuel.

The ICPP is in a fenced security areo of about $0.4 \mathrm{~km}^{2}$ located within the INEL. The ICPP facilities are designed to recover unused fissionable uranium from irradiated nuclear fuels. Usually the fuels come from the research and test reactors and from inilitary reactors.

In the recovery process the unused uronium is separated from the other fuel components and purified for future reuse. The other fuel components (jacketing materials and fission products) are separated and retained as acidic high-level liquid waste (HLLW) in underground stainless steel tanks. At the ICPP Waste Celcining Focility (WCF) this $H L W$ is converted to granulor solid (calcize), which is placed in stainless steel bins in underground reinforced-concrete voults at the ICPP.

Solid contarminated waste, except for the calcined salids, is transported to the INEL Radioactive Waste :Management Complex (RWMC); uncontaminated solid waste is deposited in a sanitary land fill. 


\section{DESCRIPTION OF FACLITIES ${ }^{21}$}

INEL is comprised of the following:

1. Arganne National Loboratory - West (ANL-W)

2. Noval Reactors Focility (NRF)

3. Idaho Chemicol Processing Plant (ICPP)

4. Test Area North, Support Focility (TAN)

5. Loss of Fluid Test Facility (LOFT)

6. Power Burst Facility (PBF)

7. Test Reactor Area (TRA)

8. Central Focilities Area (CFA)

9. INEL Solid Rodioactive Woste Monagement Areas

10. Auxiliary Reactor Area

11. Low Power Test and Experimental Beryllium Oxide Reactor Focilities

12. Idle Focilities

\section{2.) LIQUD WASTE STORAGE FACILITIES}

Of the facilities listed above only ICPP has interim storage of high-level liquid waste (prior to calcining). At al! focilities low-level liquid wastes are processed prior to discharge to the environment.

\subsection{SOLID RADIOACTIVE WASTE FACILITIES}

The solid radicactive waste facilities of the INEL are the Radioactive Woste Management Complex (RWMC), SL-1 Burial Ground, ANL Solid Waste Storage Area, and the ICPP Colcined Waste Storage Area. 
At the RWMC and SL-1 Burial Grounds, fission and ectivation product wastes are buried directly in the soil below ground level. Uranic and transuranic wastes are currently stored above the land surface in fire-resistant and watertight containers at the Transuranic Storage Area (TSA). These containers are placed on an asphalt pavement and covered with plywood-plastic and soil. At the ANL Solid Waste Storage Areo and the ICPP Colcined Waste Storage Area, radioactive wastes are stored in watertight steel containers and concrete vaults placed below the ground, Table $\mathrm{C}-\mathrm{I}$ lists the total amounts of wastes located in each of these areas as of the end of December 1974.

The estimated curie amounts cpply at the time of deposition, or, in the case of the ICPP, at the time of calcination. Radioactive decay has further reduced the amount of activity.

The following individual areos are enclosed within fences:
(I) RWMC Subsurface Disposal Area (SDA)
35.6 hectares
(2) TSA
23.5 hectares
(3) SL-I Burial Ground
1.6 hectares
(4) ANL-W Solid Waste Storage Area
2.0 hectares
(5) ICPP Colcined Waste Storage Area 1.2 hectares

Total 63.9 hectares 


\section{TABLE C-I}

TOTAL AMOUNTS OF SOLID RADIOACTIVE WASTES BY AREA $1952-1974^{21}$
Area
Volume $\left(\mathrm{m}^{3}\right)$
Curies

RWMC Subsurface Disposal

139,000

$5,978,000$

Transuranic Storage Area

24,478

93,525

SL-I Burial Ground

2,320

600

ANL Solid Waste Storage Area $(0)$

62

$9,490,171$

ICPP Colcined Waste Storage ${ }^{(a, b)}$

1,222

$\underline{52,862,000}$

Total

157,082

$58,423,696$

(a) Storage

(b) Represents $1.06 \times 10^{7}$ liters of liquid waste 


\subsection{HGHLEVEI LUUD RADHOACTIVE WASTE}

The HLLW of the ICPP is stored on on interim basis of the tank farm. All HLLW eventually is solidified in the WCF and placed in retrievable storage.

The tank farm contains eleven (11) 1.14-million liter and four (4) 114,000-liter stainless steel tanks for interim storage of HLLW22. The 1.14-million liter tanks are located in concrete voults. 


\subsection{SOLID RADHOACTIVE WASTE}

There are several areas of the INEL dedicated to the storage or disposal by burial of solid rodioactive waste material. These areas ore: (a) INEL Radionctive Waste Manogement Complex and associated Transuranic Storage Area (TSA), (b) SL-I Burial Ground, (c) High-Level Waste Storage Facility at ANL-W, and (d) Calcined Solids Storage Focilities at ICPP for storage of solid calciner product. 21

\section{I INEL RADIOACTIVE WASTE MANAGEMENT COMPLEX (RWMC) $)^{21, ~} 17$}

The RWMC wos established in 1952 to accommodate the radioactive wostes generated by Laboratory operations. In addition to wastes generated at the INEL, the RWMC has also received wastes from the DOE's Rocky Fiats Plant since 1954. Most of these wastes are contaminated with uranic and transuranic nuclides. Lesser quantities of waste hove olsa been received over the years from other DOE-associoted facilities.

The RWMC is located in the southwestern part of INEL and is enclosed by fences and surrounded by dikes and droinage channels.

In terms of area, RWMC constitutes 70 percent of all INEL waste facilities, including seepage ponds and storage oreas for high-level waste. Four major onsite contractors ship their waste to RWMC. Also, other DOE focilities throughout the country send TRU waste to RWMC for storage.

Woste received for storage or disposal must comply with DOT shipping requirements, DOE-ID Manual 0529, and RWMC documents such as waste packaging guidelines, standard practices, and operating procedures.

RWMC is divided in two fenced sections: the subsurface disposal areo (SDA), which is $35.6 \mathrm{ha}$, and the transuranic storage area (TSA), which is $22.3 \mathrm{ha}$. Approximately 8.1 ha remains for future disposal at SDA and 17.8 ha remains for future disposal at TSA. These are described below. 


\subsubsection{SUBSURFACE DISPOSAL AREA (SDA) ${ }^{21,17}$}

Underground and above-ground disposal activities are carried out in the 35.6 ha SDA. Facilities include trenches, pits and soil voults or shafts.

\subsubsection{TRENCHES}

These disposal trenches are between 150 and $300 \mathrm{~m}$ in length $\times 6 \mathrm{~m}$ in width $\times 4.5$ $m$ in diameter. They are used for the disposal of compactible solid radiocctive waste such as paper, rogs, etc., and also for most high-radiation-level (betagamma) waste.

The majority of on-site solid low-level radioactive waste, until January 1974, was received at the RWMC in carboard boxes sealed with tape. The waste was compacted to about half its volume, and a three-foot soil cover was applied. Since 1971 compactible waste generated at Naval Reactor Facilities has been compacted and sent to the RWMC in bales. Since January 1974, all other compactible waste received at the RWMC is being compacted. Use of a baletype unit that utilizes a hydraulic press to achieve a 10-to-1 reduction in waste volume has been implemented. The $270 \mathrm{~kg}$ trales are placed in specially designed fiberboard boxes with plastic liners that provide a protective container and aid stacking in the pits or trenches. Presently, most of the on-site wastes are transported to the RWMC in plastic bags to accommodate the new compaction operation. Larger noncompactible wastes arrive in wooden boxes and are stacked in the trenches along with the compacted bales.

Wastes with high ganma radiation levels are handled remotely, utilizing special shielded containers and boom cranes, When the trenches are full, they are covered with a minimum of three feet of soil.

Facilities for the TRU waste retrieval projects (Initial Drum Retrieval and Early Waste Retrieval (EWR) projects) are also located within the SDA. These retrieval activities are contained within two structures known as the air support weather shields. The EWR is double contained, with the operating area enclosed 
in a second structure within the weather shield. The waste retrieved by these projects is repackaged and placed in o 20-year retrieval storage on the TSA-R pad.

\subsubsection{PITS}

The disposal pits range in size from 30 to $45 \mathrm{~m}$ in width, 150 to $300 \mathrm{~m}$ in length, and 2 to $7.3 \mathrm{~m}$ in depth. Bulky, irregular sized wastes such as tanks, drums, piping, etco, are transported to o pit in trunks, deposited therein, and covered with soil when enough area has been filled to allow earthmoving equipment to travel across the face of the pit. Low-activity beta-gammo wastes are disposed of in these pits.

\subsubsection{VAULTS}

Soil vaults or shaits $(0.4 \mathrm{~m}$ in diameter $\times 3 \mathrm{~m}$ deep) are also used for disposal of high-activity beto-gamma wastes. These structures are expected to replace the trench concept in the disposol of bulky items such as reactor heads.

\subsubsection{TRANSLRANIC DISPOSAL AREA (TDA)}

Waste containing less than $10 \mathrm{n} \mathrm{Ci/g}$ of TRU elements is disposed of above ground on the Transuranic Disposal Area. The TDA consists of asphalt pads hoving level surfoces of Dout $1,900 \mathrm{~m}^{2}$, enclosed on three sides by an earth berm. The $7.6 \mathrm{~cm}$ asphalt surface rests upon a $10 \mathrm{~cm}$ gravel base and is sloped toward the center and the open end for drainage of moisture. One such pad is presently in use (which is designated as Transuranic Disposal Areo-TDA) at the RWMC. Drums and crates of uranic and transuranic waste containing less than $10 \mathrm{nCi}$ of transuranic activity per gram of waste, are stacked on the pad in a herizontal geometric configuration to a height of about $5.5 \mathrm{~m}$. Once a section of the pad is filled with containers, earth is moved over the top and sides of the stack to provide a moisture barrier over the waste. This storage concept allows for greater container integrity, an all-weather working surface, and moximum utilization of surface area within the RWMC. 


\subsubsection{TRANSURANIC STORAGE AREA (TSA)}

The construction of the TSA is simila to that of the TDA and affords the same advantages. Transuranic wostes containing more then $10 \mathrm{nCi} / \mathrm{g}$ of TRU elements are stored on an interim basis on this pad, which measures $45.7 \mathrm{~m} \times 228.6 \mathrm{~m}$. The pods are constructed of $7.6 \mathrm{~cm}$ of asphalt over a base of $10.2 \mathrm{~cm}$ of compacted gravel. The waste is packoged in containers designed for 20-year integrity. The bulk of the wostes stored on the TSA pad arrives at the INEL by rail from the Rocky Flats Plant. Some U-233 wostes from Bettis Atomic Power Laboratory (BAPL), which is associated with the DOE's Pittsburgh Noval Reactor Office, and other potential sources, such as the DOE's Mound Facility at Miamisburg, Ohio, are also received -along with any INEL-generated Iransuranic wastes. The containers must meet 20-year integrity requirements for storage on the TSA pad, along with other sofety and administrative imposed requ irements.

The TSA is filled in $25 \times 46-\mathrm{m}$ sections colled "cells." The drums are stacked five drums high in a close-pitched triangular array with a layer of fire-retardant plywood and plostic sheeting seprating each level. The sides of the cells are lined with $1.2 \times 1.2 \times 2.1-\mathrm{m}$ fiberglass-coated wooden boxes that contain waste too bulky for the dums. The boxes define the cells and provide end support for the drum array. Each cell in the $228.6 \mathrm{~m}$ length of the pad is separated by a 0.9 $m$-thick soil firewall as the cell is completed. The sntitire array is covered with fire-retardant plywood and nylon-reinforced polywinyl before the final 0.6 to 0.9 m-thick soil cover is placed.

Wosie containing more than $10 \mathrm{nCi} / \mathrm{g}$ of TRU elements, plus activation and/or fission products in concentrations requiring special handling, is stored in the Intermediate-Level Transuranic Storage Facility (ILTSF). This facility consists of 26 concreie-filled carbon steel storage vaults constructed from $7.9 \mathrm{~m}$ vertical pipes, 61 and $40.1-\mathrm{cm}$ in diameter. The pipes are enclosed in a $1.5-\mathrm{m}$-high earth embankment. A removable concrete plug in each vault provides shielding. Sixteen odditional vaults were scheduled for construction near the end of FY -1977 . 


\subsubsection{SOLID RADICACTIVE WASTE DATA ${ }^{21}$}

Solid radioactive waste enters the SDA and TSA in the following containers:

(I) Special shielded cask inserts (SDA)

(2) 208- and 114-liter steel drums mostly from off-site shippers (TSA)

(3) $1.2 \times 1.2 \times .2 .1 \mathrm{~m}$ wooden boxes (TSA)

(4) Compacted $0.4 \mathrm{~m}^{3}$ bales (SDA)

(5) Fiber barrels (SDA)

(6) Other special containers, such as the $0.02 \mathrm{~mm}$ yellow plastic bags used for compactible waste (SDA)

Special administrative forms contain information on waste volume and nuclide content and activity which is used as input to the DOE quarterly computerized radioactive waste reporting system (called SWIMS). Waste currently ploced in the SDA is considered disposed of, whereas that stacked in the TSA is considered stored. From 1954 through November 1970, waste containing approximately $2 \times$ $10^{5} \mathrm{Ci}$ of plutonium-contaminated waste wos disposed of ot the INEL Subsurface Disposal Area. Pu-24l comprised about 87 percent of this activity with lesser amounts of Pu-238, -239, -240, and -242. The transuranic wastes that were buried at the Radioactive Waste Management Complex prior to November 1970 are presently being retrieved. An air-support building, is being used to avoid potential contamination of the environment during the retrieval program. The air-support building is positioned over the work site, the soil overburden is removed, the disposed 208-liter drums are recovered and then repackaged in 314liter steel drums or wood and fiberglass boxes. After the drums have been removed from the area under the air-support building, the excovated area is backfilled with soil, smoothed, and graded to comply with drainage requirements. The air-support building is then moved to another location and the work sequence repeated. The repackoged drums from this retrieval program are being stored on the TSA. Ultimate disposal will be at a Federal repository. 
A summary of solid radioactive wastes stored or disposed of at the TSA and SDA during 1974 is given in Toble C-2.

Table C-3 is a list of the radiooctive nuclides disposed of at the INEL in 1974. The radipactive nuclides stored at the TSA during 1974 are !isted in Toble C-4. Toble C-5 shows a 21 -year summary of wastes disposed of at the SDA or stored of the TSA.

Figures C-1 and C-2 show grophically the total volume and activity of solid wastes handled from 1952 through 1974 while Figures $\mathrm{C}-3$ and $\mathrm{C}-4$ present the cumulative waste generations.

\subsection{SL-I BURIAL GROUND 21}

SL-1 experienced an accidental nuclear excursion on January 3, 1961, which destroyed the reactor and contaminated the reactor building. The reactor and reactor building were dismantled. Most of the dismantled building, contaminated equipment, and the decontomination waste were interred directly in a burial ground established a short distance from the facility.

Only bout five percent of the fission products from the excursion (cbout 130 MW-sec) escoped from the pressure vessel during the accident. The uranium was oll reclaimed except for a little less than one $\mathrm{kg}$. Measurements of waste going into the SL-I Burial Ground indicate that about $600 \mathrm{Ci}$ were interred owing to the accident. Since the SL-I disposal area was only for waste from the one incident, this amount constitutes the total material buried in the orea. No wastes have been buried there since 1962 .

The total area within the exclusion fence around the disposal area is bout 1.7 hectares. 
TABLE C-2

SOLID RADIOACTIVE WASTE STORED OR DISPOSED

OF AT INEL SDA OR TSA DURING $1974^{21}$

\section{DISPOSED-OF WASTES}

Originating Focility

ANL

ARA

CFA

CPP

NRF

SPERT

TAN

TRA

Rocky Flats

Total

Volume

$\left(\mathrm{m}^{3}\right)$

269

23

218

963

275

28

201

215

1,526

3,718
19,770

Curies

708

16

5,739

5,822

I

6,736

736

10

\section{STORED WASTE}

TSA

4,135

23,530

C-12 
TABLE C-3

SOLID RADIONUCLIDES DISPOSED OF AT INEL SDA DURING $1974^{21}$

Nuclide

Curies

Antimony-125

107

Cerium-141

2

Cerium-144

805

Cesium-134

66

Cesium- 137

Chromium-51

1,424

Cobalt-58

82

Cobalt-60

Europium-154

Europium-155

7,662

42

Iron-59

Manganese-54

Mixed activation products

Mixed fission products

Nickel-59

Plutonium-238

Plutonium-239

Plutonium-240

Plutonium-241

Plutonium-242

Praseodymium-144

Radium-226

Rhodium-106

Rubidium-86

Ruthenium-106

Strontior -90

Thor: $11.22 ?$

Uraniuni-:?

Uronivim- 25

Uronium-238

Unidentified ulpho

Unidentified beta and gammo

Yttrium-90

Zinc-65

Zirconium/niobium-95

Total

154

19,770 
TABLE C-4

TSA NUCLIDE SUMMARY IN CURIES FOR $1974^{21}$

Nuclide

Curies

Americium-241

4,453

Mixed fission products

22

Plutonium-żs

58

Plutonium-2.39

1,921

Plutonium-240

472

Plutorium-241

Plutonium-242

16,390

Uronium-232

Uronium-233

204

Uronium-238

Total

23,530 


\section{TABLE C.5}

SOLID RADIOACTIVE WASTE DISPOSED OF OR STORED AT RWMC 1952-1974 ${ }^{21}$

\begin{tabular}{|c|c|c|c|}
\hline \multicolumn{2}{|c|}{ Disposed } & \multicolumn{2}{|c|}{ Stored } \\
\hline $\begin{array}{c}\text { Volume } \\
\left(\mathrm{m}^{3}\right)\end{array}$ & Curies & $\begin{array}{c}\text { Volume } \\
\left(\mathrm{m}^{3}\right)\end{array}$ & Curies \\
\hline 61,738 & 771,300 & & \\
\hline 7,533 & 702,900 & & \\
\hline 9,487 & 924,300 & & \\
\hline 9,657 & 877,800 & & \\
\hline 13,735 & 301,500 & & \\
\hline 11,498 & 971,000 & & \\
\hline 12,517 & 504,400 & 1,416 & 4,225 \\
\hline 4,022 & 350,900 & 7,108 & 12,670 \\
\hline 3,540 & 214,700 & 5,919 & 28,500 \\
\hline 3,880 & 339,800 & 5,891 & 24,600 \\
\hline 3,718 & 19,700 & 4,135 & $\underline{23,530}$ \\
\hline
\end{tabular}

Total

141,325

$5,979,000$

24,469

93,525 


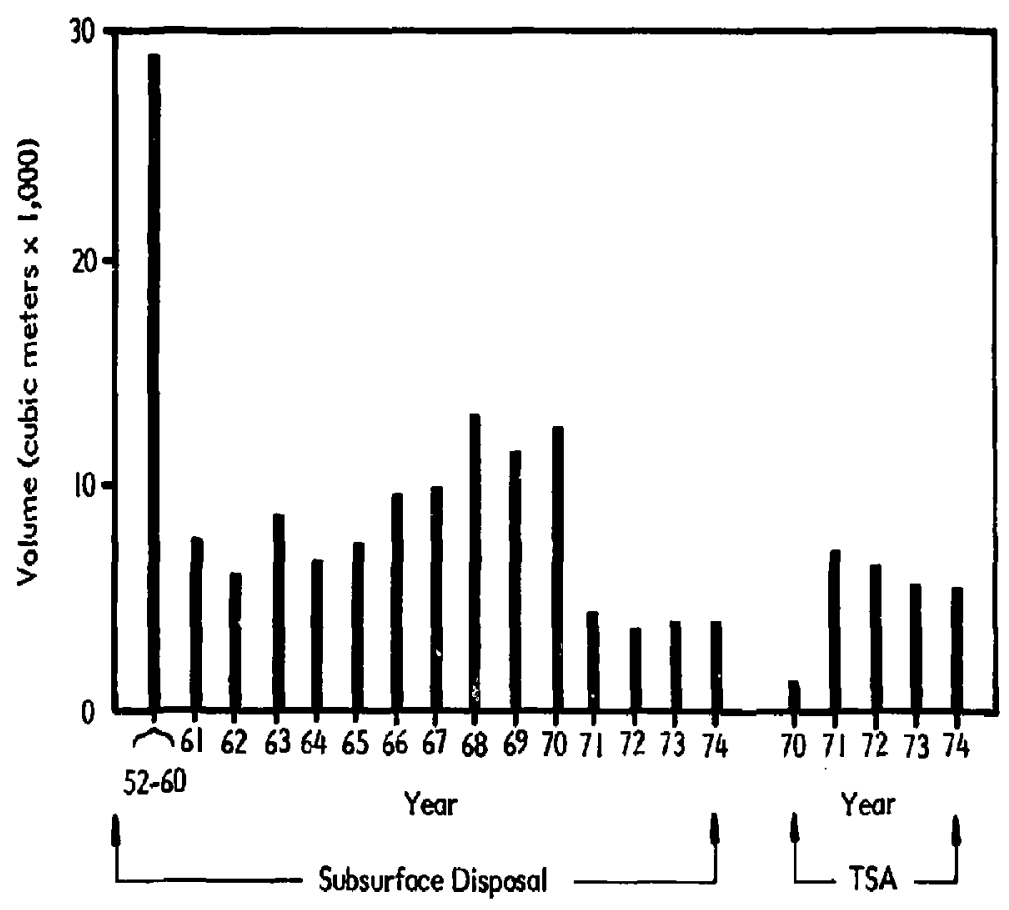

FIGURE C-I

VOLUME OF RADIOACTIVE SOLID WASTES HANDLED AT INEL SDA AND TSA BY YEAR ${ }^{2 I}$ 
L

[

I

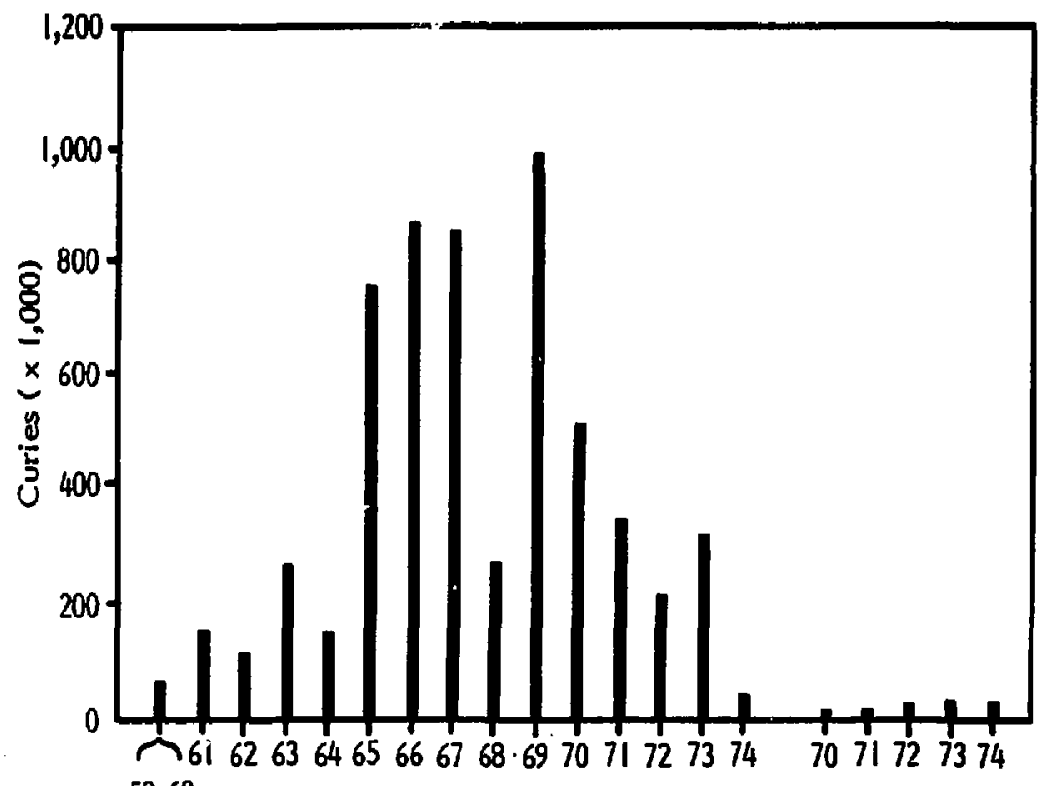
$52-60$

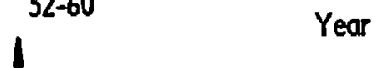

Subsurface Disposal

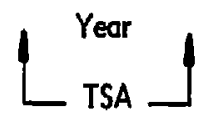

FIGURE C-2

ACTIVITY OF RADIOACTIVE SOLID WASTES HANDLED AT INEL SDA AND TSA BY YEAR ${ }^{2 ।}$ 


$$
\underline{\underline{\nu}}
$$




\subsection{ICPP CALCINED SOLID STORAGE FACILITIES ${ }^{21,} 22$}

The ICPP calciner storage bins area is considered a solid waste management location. These underground engineered receiving bins store the solid calciner product. These storage bins were first put into service in 1963 and through 1974 approximately 53 million $\mathrm{Ci}$ of radionctivity representing $12,255 \mathrm{~m}^{3}$ of total volume have been stored within them. Almost 100 percent of this radionctivity is composed of $\mathrm{Sr}-90$ and Cs-137. Toble C-6 gives the quantity of colcined solid waste. Calcined solid waste is expected to continue ot a rote of $140 \mathrm{~m}^{3}$ per year until approximately 1980 when a new calciner will be available. Solid calcine waste generation will then be $450 \mathrm{~m}^{3}$ per year. Table C-7 presents typical properties of the calcined solids which are generated at ICPP. 22

Other solid radioactive wastes generated and handled at the ICPP include filter cartridges, WCF off-gas filters, ion-exchange resins, sediment from settling basins, and hot waste boxes containing low-level contaminated wastes. Approximately 600 to $700 \mathrm{~m}^{3}$ of solid waste typically are sent to the RWMC annually. The waste is packoged in cardboard boxes, wooden boxes, and metal drums. All solid wastes from the ICPP are monitored for volume, radioactivity, and major nuclides prior to disposal.

\subsection{AML RADIOACTIVE SCRAP AND WASTE FACILITY ${ }^{21}$}

The ANL Radiaactive Scrop and Waste Facility is a controlled access, fenced 1.6 hectare orea. The facility is $120 \mathrm{~m}$ wide by $137 \mathrm{~m}$ long. The storoge site utilizes storage holes with steel liners which are fobricated of Schedule 10 pipe $13.7 \mathrm{~m}$ long and $0.4 \mathrm{~m}$ outside diameter with $0.64 \mathrm{~cm}$-thick wally. They are welded closed at the bottom end and provided with a top clasure plate. The top plate is welded on after the material has been deposited in the liner and has been shielded with a concrete plug. Grovel shielding was used in some cases prior to 1974.

The facility was designed for 27 rows on $3.7 \mathrm{~m}$ centers with approximately 40 holes per row on $1.8 \mathrm{~m}$ centers allowing space for approximately 1,080 holes. 
TABLE C-6

RADIOACTIVE LIQUID WASTE SOLIDIFIED

BY FLUIDIZED BED CALCINATION 22

\begin{tabular}{|c|c|c|c|}
\hline Compaign & $\begin{array}{c}\text { Liquid } \\
\text { Volume Calcined }(0) \\
\text { (liters) } \\
\end{array}$ & $\begin{array}{c}\text { Solid } \\
\text { Woste Produced (b) } \\
\left(\mathrm{m}^{3}\right) \\
\end{array}$ & $\begin{array}{l}\text { Radioactivity }\langle c\rangle \\
\text { (Ci) }\end{array}$ \\
\hline $\mathrm{H}-\mathrm{I}$ & $1,934,000$ & 215 & $10.0 \times 10^{6}$ \\
\hline $\mathrm{H}-2$ & $3,744,000$ & 413 & $19.7 \times 10^{6}$ \\
\hline $\mathrm{H}-3$ & $1,245,000$ & 159 & $3.2 \times 10^{6}$ \\
\hline $\mathrm{H}-4$ & 851,000 & 130 & $1.2 \times 10^{6}$ \\
\hline H-5 & $1,136,000$ & 150 & $6.6 \times 10^{6}$ \\
\hline$H-6$ & $1,175,000$ & 185 & $5.1 \times 10^{6}$ \\
\hline $\mathrm{H}-7^{(\mathrm{d})}$ & $1,514,000$ & 228 & $6.0 \times 10^{6}$ \\
\hline TOTALS & $11,600,000$ & 1,480 & $51.8 \times 10^{6}$ \\
\hline
\end{tabular}

(a) Nonradiocctive liquid wastes used for startup checkout are not inclusted, and WCF decontamination wostes are not subtracted.

(b) Solids include radioactive and nonrodioactive calcine and the starting-bed material.

(c) Activities are computed at time of calcination.

(d) Projection for the part of $\mathrm{H}-7$ in FY 1976 tronsition quarter (to October I, 1976). 
TABLE C-7

TYPICAL PROPERTIES OF CALCINED SOLIDS ${ }^{22}$

\section{Fluoride Waste Nonfluoride Waste}

Bulk Density, $\mathrm{kg} / \mathrm{m}^{3}\left(\mathrm{lb} / \mathrm{ft}^{3}\right)$

$1600(100)$

$1120(70)$

Heat Generation Rate, W/kg

$0.065-0.13$

0.26

Chemical Properties

$\begin{array}{lcc}\text { Metallic Oxides (w+\%) } & 43.3 & 89.2 \\ \text { Nitrogen as } \mathrm{N}_{2} \mathrm{O}_{5}(w+\%) & <1.0 & 4.0 \\ \text { Water as } \mathrm{H}_{2} \mathrm{O}(w+\%) & <1.0 & <2.0 \\ \text { Calcium as } \mathrm{CoF}_{2}(w+\%) & 54.2 & 0 \\ \begin{array}{l}\text { Fission Product and Other } \\ \text { Oxides or Fluorides (wt \%) }\end{array} & 0.5 & 4.8\end{array}$

Rodiochemical Properties

$\mathrm{Cs}-137, \mathrm{Ci} / \mathrm{kg}(\mathrm{Ci} / \mathrm{b})$

$2.86(1.30)$

$17.6(8.00)$

Sr-90, Ci/kg (Ci/lb)

$3.52(1.60)$

$13.2(6.00)$

$\mathrm{Pu}, \mathrm{Ci} / \mathrm{kg}(\mathrm{Ci} / \mathrm{lb})$

$0.01(0.0045)$

$0.02(0.009)$ 
The facility was first used in 1965 and through 1974 has received $56.6 \mathrm{~m}^{3}$ of waste totaling $\mathrm{s} 10$ million $\mathrm{Ci}$ of rediooctivity, all of which originated at ANL. The material consists primarily of waste metal from fuel handing and refabrication operations. The waste is renotely loaded into o steel waste can which is then sealed and placed in a top-looding, bottom-unlooding waste handling cask. The cask provides adequate shielding for personnel protection and when loaded is removed from the loading cell and transported on a special truck to the storage site. The special truck allows the cask to be positioned directly over an empty hole for easy placement of the steel waste can. Table C-8 shows the nuclide summary for 1974, and Table C-9 gives the summary of waste stored in the facility from 1965 through 1974.

If in the future it should become desirable to do so, the storage liners (complete with contained waste) could be retrieved. A detailed surface and structural examinotion of an empty underground storage tube was conducted after 5-1/2 years of use. The examination included a visual abservation of the surface, microstructural, and microneter measurements. The storage containers received only slight corrosion on the outer surfoces. The small deviotions observed from the "as-specified" wall thickness of the container indicate that the integrity of the contoiner is well preserved and prolonged life can be expected under identical exposure conditions.

\subsection{ACCUMULATED WASTE}

The total volume of waste that has been disposed of at INEL (through 1976) is $156,150 \mathrm{~m}^{3}$ of primarily mixed fission and activation products. Also, $266 \mathrm{~kg}$ of TRU elements hove been stored, and $332 \mathrm{~kg}$ were buried prior to the retrievobility requirement. 17 
TABLE C-8

ANR W STORAGE AREA NUCLIDE SUMMARY FOR $1974^{21}$

Nuclide

Curies

Chromium-5!

19,090

Cobalt-58

8,354

Cobalt-60

47,920

Manganese-54

9,802

Mixed uctivation products

5,744

Mixed fission products

603

Plutonium-239

23

Uranium-235

Uranium-238

Total

91,536 


\section{TABLE C-9}

SOLID RADIOACTIVE WASTE STORED AT ANLW 1965-1974 21

\begin{tabular}{ccr} 
Year & Volume $\left(\mathrm{m}^{3}\right)$ & \multicolumn{1}{c}{ Curies } \\
\cline { 2 - 3 } 1965 & 7 & 760,797 \\
1966 & 16 & $2,454,465$ \\
1967 & 13 & $1,492,504$ \\
1968 & 9 & $1,878,902$ \\
1969 & 5 & 950,961 \\
1970 & 2 & 671,900 \\
1971 & 3 & 476,733 \\
1972 & 4 & 274,073 \\
1973 & 2 & 438,300 \\
1974 & 1 & 91,536 \\
Total & 62 & $9,490,171$
\end{tabular}


I

[

[

[

[

[

[

I

APPENDIXD

[

SAVANNAHRIVER PLANT (SRP)

[

Г

[

[

[

IERACOPPORATION. 


\section{I.0 BACKCROUND 23,24}

Since 1953, the Sovannah River Plont (SRP), near Aiken, South Carolina, has been producing special nuclear materials, primarily plutonium and tritium, for defense purposes. The SRP facilities were constructed and initially operated for the Atomic Energy Commission. Operation since 1975 has continued under the direction of the Energy Research and Development Administration (ERDA) and presently the Department of Energy (DOE).

The SRP operations produce high-level radioactive waste in the chemical processing of fuel and target elements after irradiation in the SRP nuclear reactors. This waste is stored as an alkaline liquid with a precipitated sludge until the decay heating hos abated appreciably. Then the supernatant liquid is converted to salt cake to reduce volume and mability. The storage facilities are large underground tanks that are engineered to provide relicble isolation of waste from the environment.

At SRP, solid wastes contaminated with transuranium nuclides are generated primarily in the final purification oreas (B lines) of the two separations plants. Wastes from the $B$ line of the $F$ plant contain principally Pu-239 while those from the $B$ line of the $\mathrm{H}$ plant contain principally Pu-238. All wastes are buried in 0 local on-site burial ground. Through colendor yeor 1965, most waste wos in cardboard cartons with relatively little provision for confinement and retrievability. Since that time, coincident with large scale processing of Pu-238, most wastes containing > 0. curie of Pu-239 or Pu-238 per package have been encosulated in concrete before burial to immobilize the waste and to facilitate possible future retrieval. 


\section{LUQUD WASTE STORAGEFACLITES ${ }^{23}$}

\subsection{HIGH-LEVEL LIQUID WASTES}

Liquid rodioactive wastes are produced at SRP primarily from nuclear fuel reprocessing operations in the $F$ and $\mathrm{H}$ Areas. These wastes are stored in large underground tanks in these areas by methods that do not preclude any of the possible options for long-range management of the wastes.

Recovery processes in the hot (heavily shielded) and warm (moderately shielded) conyons generate aqueous waste streams that contain most of the fission products. These waste streams that come from the warm canyon are referred to as low-heat waste (LHW) and those from the hot canyon are high-heat waste (HHW). This terminology is used to identify the source of the waste and to indicate that LHW will not require auxiliary heat removal, as does HHW. The term "high-level liquid waste" includes both HHW and LHW. The wastes are made alkaline and flow by gravity from the processing buildings to the waste storage tank farm.

Fresh waste is aget for one to two years to permit settling and the decay of short-lived fission sts. During this period insoluble materials settle to form a layer of sludge at the bottom of the tank. The sludge is a mixture of oxides and hydroxides of manganese, iron, and some aluminum; small amounts of uranium, plutonium, and mercury; and essentially all of the fission products originally in the irradiated fuel except cesium. After aging, the supernate, containing dissolved salts and radioactive cesium, is transferred to a continuous evaporator. The concentrate from the evoporator is transferred to a cooled waste tank where the suspended salts settle. After cooling, addit:onal salt crystallizes. The supernate is returned to the evoporator for further concentration. This process continues until the liquid has been converted to a crystallized salt cake. The low-heat waste is handled similarly to high-heat waste. Low-heat salts are now being accumulated in uncooled waste tanks. 
Ranges of chemical compositions, principol long-lived radioactive constituents and other properties of high-level liquid wastes (LHW and HHW) are presented in Table D-1.

At present, SRP hos 30 large subsurfoce tanks for the storage of aqueous radioactive wastes, as sludge, supernatant liquid of various solt concentrations, and salt coke. Sixteen of these tanks are adjacent to one separations plant (H Area) and 14 are adjocent to the other (F Area). Three additional tonks are nearing completion in $\mathrm{H}$ Area, and four tanks ore under construction in $\mathrm{F}$ Area. All of the waste tanks are below ground, and are built of carbon steel and reinforced concrete, but they are of four somewhat different designs. Three designs hove double steel walls and bottoms and forced water cooling systems and ate used primarily for high-heat waste and waste concentrate; the fourth design has a single steel wall directly supported by the encasing reinforced concrete, has no forced cooling, and is used primarily for low-heat waste and concentrate. 23

Table D-2 summarizes the volumes of total waste, sludge, and solt in the tanks as of December 1975.

Net accumulation of stored waste from current fresh waste receipts and tank farm evcporator operation is expected to continue at no more than an average rate of 3.8 million liters per year. The volume of liquid supernate stored in the waste tanks will vary with time as waste management operations are carried out to relocate existing and new wastes. Transfer of existing salt cake and sludge to new or improved tanks will temporarily increase the total volume of waste because of the water added to accomplish the transfers. Addition of new evcporators and improved in-tank coolers will reduce the liquid volume.

Spare volume is maintained in sound double-wall tanks in each of the two waste tank areas ( $F$ and $H)$. This volume is equivalent to the largest volume of waste stored in any one tank. New waste tanks that are now under constr.sction or plamed will endole the replacement of all single-wall tanks and those doublewall tanks that hove leaked waste liquid and salt into the annulus between the primary and secondary steel container. 
TABLE D-I

RANGE OF CHEMICAL COMPOSITIONS OF

SRP HIGH-LEVEL LIQUID WASTES ${ }^{23}$

Constifuent

Supernate

$\mathrm{NaNO}_{3}, \mathrm{NaNO}_{2}$

$\mathrm{Na}_{2} \mathrm{CO}_{3}$

$\mathrm{Na}_{2} \mathrm{SO}_{4}$

$\mathrm{NaOH}$

$\mathrm{NaAl}(\mathrm{OH})_{4}$

Sludges ${ }^{(0)}$

$\mathrm{MnO}_{2}$

$\mathrm{Fe}(\mathrm{OH})_{3}$

Radioisotopes

Sr-90

Cs-137

Pu-238

Pu-239

\section{Concentration}

3 to $6 M$

0.1 to $0.3 M$

0.02 to $0.2 \mathrm{M}$

1 to $6 \mathrm{M}$

0.4 to $1.0 \mathrm{M}$

Principal constituents

of sludge

0.3 to $180 \mathrm{Ci} / \mathrm{I}$

0.3 to $6 \mathrm{Ci} / 1$

0.0003 to $0.3 \mathrm{Ci} / 1$

0.03 to $6 \mathrm{~m} \mathrm{Ci/l}$

(a) Settled volume $s 10 \%$ of supernate volume. 


\section{TABLE D-2}

CONTENTS OF HIGHLLEVEL LIQUID WASTE TANKS DECEMBER $1975^{23}$

$\amalg$

$\prod$

U)

Volume of sludge

9.0

Volume of solt cake $\quad 25.5$

Volume of liquid supernate $\quad 42.8$

Totol unoccupied storoge space

$33.7^{(0)}$

Millions

of lifers

Total volume of waste, $F$ and $H$ Areas

77.3

90

$\sqrt{15}$

(a) Includes working volume and emergency spare volume. 
All of the new tanks will be of the latest type, with the primary container fully stress-relieved and o full height secondary container.

By the mid-1980's, all of the high-level liquid waste is estimated to be stored in tanks completed in 1970 or later. Eveporators will be constructed as needed so that waste evaporation capacity will not limit the tank replacement program.

Current waste management practices, including the construction of new doublewall waste tonks to replace the older single-wall and leaking double-wall tanks, do not preclude any of the possible options for long-term management of SRP wastes. These options include improvement in current practices based on continued surveillance and maintenance and, at the other extreme, complete removal of the wastes from tonk storage and conversion to an inert solid form for ultimate storage. It has been demonstrated at SRP that the waste salt can be redissolved and that the settled sludge con be removed by a combination of hydroulic and chemical cleaning. 


\subsection{SOLID RADIOACTIVE WASTE STORACE SITE (BURIAL GROUND)}

\subsection{FACILITY DESCRIPTION ${ }^{23,17}$}

One centrally located solid radioactive waste storage site is used to store all radioactive solid waste produced at the Savannah River Plant as well as occasional special DOE shipments from off-site. This storage site occupies 78.9 hectares epproximately $10 \mathrm{~km}$ from the nearest plont boundary. The original orea of 31 hectares, which began to receive waste in 1953, was filled in 1972, and operations were shifted to a 48-hectare site contiguous to the original area. A paved road io its entrance and many unpaved roads inside the fenced area provide access for trucks, the usual transportation mode for solid waste. Three railroad spurs permit shipments of large pieces of contaminated process equipment from the plant's operating areas.

The solid waste storage site is divided into sections for accommodating various levels and types of radioactivity in waste materials: transuranium (TRU) alpho waste, low beta-gamma waste, and high beta-gamma waste (high beta-gamma and low beta-gamma solid radioactive wastes are those containing primarily beto-gamma emitters which are segregated according to raciation measurement). Examples of the materials in storage include:

- Contaminoted equipment - obsolete or failed tanks, pipes, jumpers, and other process equipment from the fuel separations plants.

- Reactor and reactor fuel hardware - fuel components and housings not containing irradiated fuel and spent deionizer resins.

- Spent lithium-oluminum targets - the waste target alloy after tritium has been extracted.

- Oil from gas displacement pumps in the tritium facilities before burial, oil is placed in drums containing an absorbent material. 
- Mercury from gas pumps in iritium focilities - before initiation of recyuling in 1968, deteriorated and contominated mercury was buried with primary containment by one-liter polyethylene bottles.

- Incidental waste from laboratory and production operations - small equipment, spent air filters, clothes, onalytical waste, decontamination residues, plastic sheeting, and gloves.

- Occasional shipments from offsite - tritiated woste from the Mound Focility, Pu-238 process waste from Los Alamos Scientific Laboratory (LASL) and the Mound Facility, and debris from two U.S. military airplane accidents in foreign countries.

Accurate records are kept of the contents, radiation level, and storage location of each load of waste. Shipments are described and recorded, and permanent computerized records are maintained on mognetic tape. The exoct locotion of the burial trenches is defined by use of a $30.5-\mathrm{m}$ grid system loid out in 1962. The 30.5-m grids are further divided into twenty-five 6.1 -m squares.

\subsection{STORACE MODES $\mathrm{S}^{23,17}$}

There are two types of facility storcge modes at SRP: pads and trenches. Waste emplacements are covered promptly with soil to reduce radiation exposures and the poteritial of fire and wind-blown contamination. When a trench is nearly filled with waste, it is backfilled with soil. The minimum soil cover is $1.2 \mathrm{~m}$, but it must be sufficient to reduce surface radiation to $6 \mathrm{mR} / \mathrm{hr}$ or less.

\subsubsection{TRU WASTE ${ }^{23}$}

Transuranic waste was originally buried in plastic bogs and cardboard boxes in earthen trenches designated specifically for this waste. At Savannah River beginning in 1965, TRU waste was segregated according to TRU content into two categories, retrievable and nonretrievable, and additional containment was added for retrievable waste. Waste containing greater than $0.1 \mathrm{Ci}$ per package was placed in prefabricated concrete containers and then buried. These retrievable 
containers were 1.8 meters in diameter by 2 meters high. Waste that did not fit into the prefobricated concrete containers was eiccopsulated in concrete, Transuranium waste from the Sovannah River Laboratory was buried in cubical concrete containers. Waste containing less than $0.1 \mathrm{Ci}$ per package was buried unencopsulated in alpha trenches. A total of $242,900 \mathrm{~m}^{3}$ was buried under these practices, $^{17}$

In 1974, the storage procedures were modified to reflect new DOE criteria governing retrievable storage of solid transuranic woste. Transuranium wastes contaminoted to greater than $10 \mathrm{nCi} / \mathrm{g}$ are now stored, protected from contact with water-saturated soil, in containers that can be retrieved intact and free of external contamination for af least twenty years from the time of storage. Combustible and noncombustible wostes are stored in separate containers. Polyethylene-lined galvanized drums are used as the primary container; waste packages containing more than $0.1 \mathrm{Ci}$ are odditionally protected by closure in concrete cylinders, Containers are stored on a steel-bar-reinforced concrete pad ( $18 \mathrm{~m}$ in width by $46 \mathrm{~m}$ in length by $0.3 \mathrm{~m}$ in thickness) and covered with $1.2 \mathrm{~m}$ of earth. The top loyer is covered with aspholt and soil and then seeded. in accordance with DOE Monuol 05II, camyon equipment and other bulky wastes contaminated with transuranium muclides to greater than $10 \mathrm{nCi} / \mathrm{g}$ and also intensely contaminated with gamma emitters are stored directly in earthen trenches protected from contact with water-saturated soil. Waste is placed in the trench and covered with soil soon after its placement. The minimum soil cover is $1.2 \mathrm{~m}$ or as deep as is needed to reduce surface radiation to at least 6 $\mathrm{mR} / \mathrm{hr}$.

\subsubsection{BETA-GAMMA WASTE}

Waste contaminated with beta-gamma emitters is separated into two categories for burial: low beta-gamma and high beta-gamma. Low beta-gamma waste is defined as waste measuring less than $50 \mathrm{mR} / \mathrm{hr}$ at $7.6 \mathrm{~cm}$ from an unshielded package and less than $50 \mathrm{mR} / \mathrm{hr}$ at $3 \mathrm{~m}$ from the truck load. This waste is disposed of in low beta-gamma woste trenches. Scrop unirradiated uranium is 
also classified as low beta-gammo waste, but it is buried in separate trenches. Irradiated reactor fuel housing components, tritium waste (clossified as high beta-gamma waste becouse of induced activity associated with the Li-Al melts from the process facility), and miscellaneous waste in cardboard boxes are segregated and buried in separate trenches.

Trenches are $6 \mathrm{~m}$ wide $\times 6 \mathrm{~m}$ deep ond up to $215 \mathrm{~m}$ long. The totol trer.ich length that had been utilized from the beginning of SRP operations through 1976 was 25 $\mathrm{km}$ in an area of 14.6 ho.

\subsubsection{SOLVENT}

Degraded solvent from the chemical separations areas is stored in underground tanks at the burial ground. The present inventory of 562,000 liters contains about $45 \mathrm{Ci}$ of TRU nuclides (Pu-238, Pu-239, $\mathrm{Cm}-244$ ) and obout $50 \mathrm{Ci}$ of fission product nuclides. The solvent storage facility consists of six bitumastic-cooted, mild steel tanks of 94,000-liter copacity, which were installed in 1975. Each tank hos a sump with liquid level monitored weekly for lecks. In addition, two older 94,000-liter mild steel tanks are used to store solvent with the lowest level of radioactivity. The liquid level in all eight tanks is measured weekly to detect lecks. The expected rate of waste solvent generation is about 19,000 liters per year.

\subsection{QUANTITY OF WASTE 23,17}

The estimated volume and curie content of woste buried in 1975 is listed in Table D-3. The total estimated volume and curies of waste in storage ore summarized in Table D-4. Table D-5 presents the maximum quantities of radionuclides stored at a single location.

A total of $273,348 \mathrm{~m}^{3}$ of waste, which contains $4270 \mathrm{KCi}$ of radioactivity, has been disposed of at SRP. The TRU wastes which are stored occupy a volume of $1563 \mathrm{~m}^{3}$ and contain $52 \mathrm{~kg}$ of transuranic nuclides. ${ }^{17}$ 
TABLĖ D-3

SOLID WASTE BURIED IN 1975 FROM SRP OPERATIONS (a)23

\begin{tabular}{|c|c|c|c|c|c|c|}
\hline \multirow{2}{*}{$\begin{array}{l}\text { Radio- } \\
\text { nuclide }\end{array}$} & \multicolumn{2}{|c|}{ Earthen Trenches } & \multicolumn{2}{|c|}{ Retrievoble Storage } & \multicolumn{2}{|c|}{ Totol } \\
\hline & Volume, $\mathrm{m}^{3}$ & Curies & Volume, $\mathrm{m}^{3}$ & Curies & Volume, $\mathrm{m}^{3}$ & Curies \\
\hline Cf-252 & 4 & - & 40 & 1.5 & 44 & 1.5 \\
\hline $\mathrm{Cm}-244$ & 400 & - & 10 & 50 & 410 & 50 \\
\hline Pu-238 $(c)$ & $420^{(b)}$ & (b) & 40 & 4,190 & 483 & 4,330 \\
\hline $\mathrm{Pu}^{2} 239^{(\mathrm{d})}$ & 770 & & 80 & 160 & 850 & 160 \\
\hline Np-237 & 50 & - & 10 & 0.4 & 60 & 0. \\
\hline U-238 & 540 & 1.2 & 1 & - & 541 & I: \\
\hline U-235 & 220 & 0.002 & 3 & - & 223 & 0.02 \\
\hline$H-3$ & 1,000 & 59,500 & - & - & 1,000 & 59,500 \\
\hline $\begin{array}{l}\text { Fission } \\
\text { Products }\end{array}$ & 6,470 & 65,500 & 2 & 90 & 6,470 & 65,600 \\
\hline $\begin{array}{l}\text { Activa- } \\
\text { tion } \\
\text { Products }\end{array}$ & 320 & 71,500 & 10 & 400 & 330 & 71,900 \\
\hline Totals & $10,200^{(b)}$ & $197,000^{(b)}$ & 200 & 4,900 & 10,400 & 202,000 \\
\hline
\end{tabular}

(a) Volumes and curies rounded to no more than 3 significant figures.

(b) These totals do not include a process vessel vent filter in o $23 \mathrm{~m}^{3}$ steel tank estimated to contain less than $140 \mathrm{Ci}$ Pu-238 which is buried in an earthen trench. This filter also contains an estimated $6,000 \mathrm{Ci}$ of fission products. Such equipment is excluded from surface storage by DOE Manual Chapter 05II.

(c) The Pu-238 waste typically contains 81 percent Pu-238, 15 percent Pu-239, three percent Pu-240 and one percent Pu-241.

(d) The Pu-239 waste typically contains about 94 percent Pu-239 and six percent Pu240. 
TABLE D-4

SOLID RADIOACTIVE WASTE STORED IN BURIAL GROUND (a)23

(THROUGH 1975)

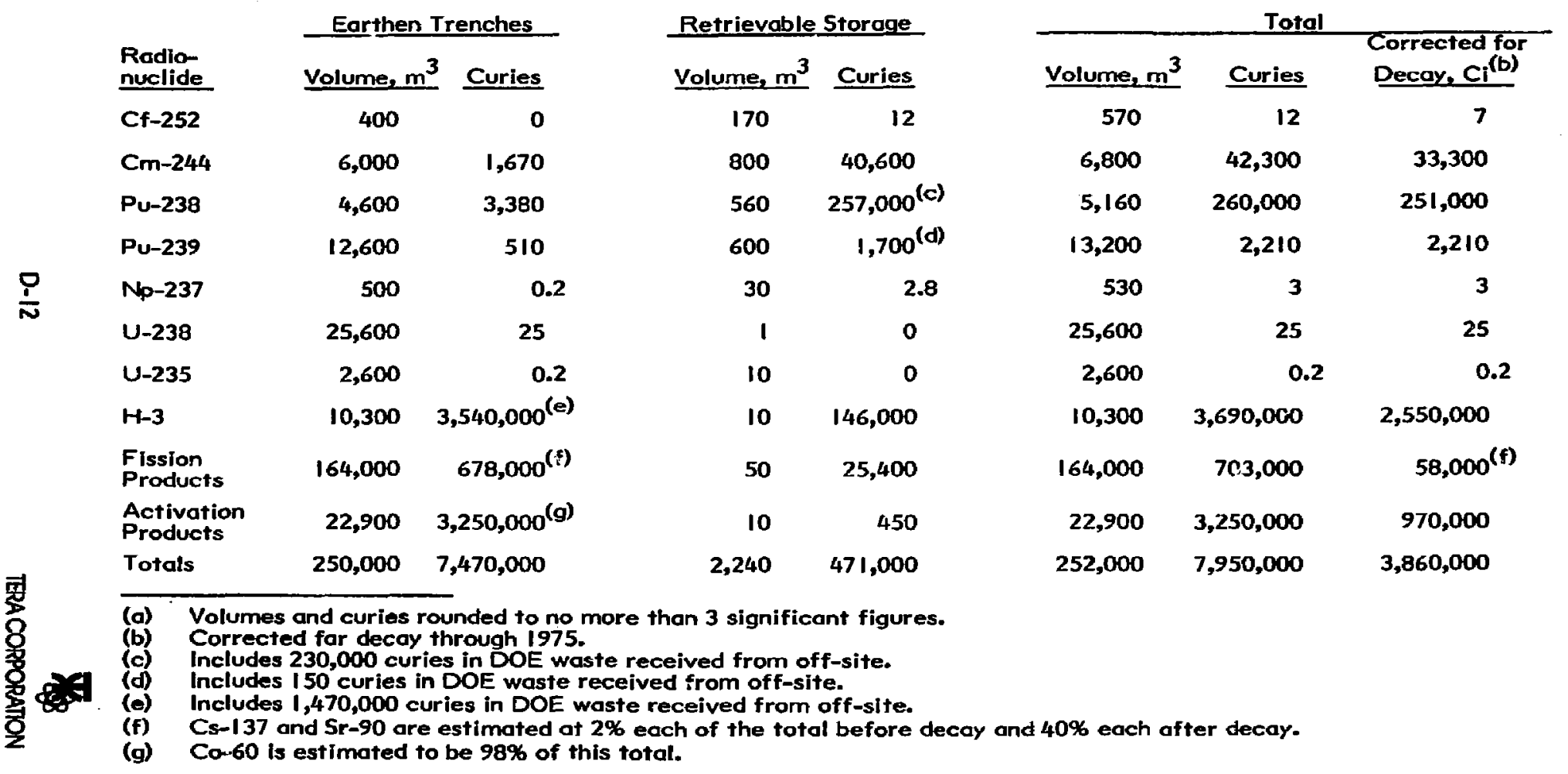




\section{TABLE D-5}

\section{MAXIMUM QUANTITIES OF BURIAL GROUND RADIONUCLIDES STORED AT SINGLE LOCATIONS ${ }^{23}$}

Isotope

Pu-238 High-level transuranium cobinet waste in lined, steel drums. Fourteen drums are placed in a concrete container. Container is open prior to seoling.

Pu-239 Same as above

Cm-244 High-level transuranium waste from SRL in lined steel drums. Fourteen drums are placed in a concrete container. Container is open prior to sealing.
Maximum Quantity, Ci

2000 per concrete concrete cortainer ( 550 per drum)

23 per concrete container (12 per drum)

1800 per concrete concrete container (500 per drum) 


\subsection{WASTE CHARACTERISTICS ${ }^{2}$ ?}

The solid wastes at SRP can be divided into six categories. These will be individually discussed to provide insight into SRP solid waste cheracteristics.

\subsubsection{CARDBOARD BOXES BURIED IN TRENCHES}

These wastes generally originate in gloved enclosures and their associated laboratories. They are characterized by relatively high combustible content and relatively low external radiation level. Through 1965 a total of about $2 \mathrm{~kg}$ of Pu239 was buried in this manner. Since that time these wastes have been limited to no more than 0.1 curie per package on the basis of a passive gamma analysis. The most common cardooard box is a $38 \mathrm{~cm}$ cube. Other sizes that are used include 61- and 76-cm cubes. Approximately 70 percent of all woste buried through 1970 consisted of cardboord boxas. It is estimoted that if this waste were retrieved the volume of the restored waste would be triple the original volume.

\subsubsection{BOXED OR DRUMMED WASTE IN CONCRETE CULVERTS}

Since 1965 cardboard cortons or metal drums containing < 0.1 curie per package (principally combustible waste hoving low external radiation level) hove been placed in large concrete containers before burial. These containers have inside dimensions of $1.8 \mathrm{~m}$ diameter $\times 1.8 \mathrm{~m}$ tall and outer dimensions of $2.1 \mathrm{~m}$ diameter $2.1 \mathrm{~m}$ tall. These containers are made by pouring a concrete bottom in o standard culvert section. After the container is filled the top is sealed in place using epoxy resin. These concrete containers weigh about $7,000 \mathrm{~kg}$. This waste form makes up 2.6 percent of the total waste buried through 1970.

\subsubsection{LARGE EQUIPMENT IN MONOLITHIC POURS}

Large items of equipment significantly contaminated with transuranium nuclides - encased in wooden or metal boxes to promote safe transport to the burial 
ground - ore further encased in concrete using the earth as a form. After a concrete footing is poured in on earth excavation of suitable size, the boxed waste is placed on the footing and concrete is poured all oround and on tcp. A total of about 200 such burials have been made through 1970 lapproximately 3.3 percent if total waste buried). Outer dimensions of the concrete pours have varied from cbout $1.2 \mathrm{~m}$ cubes to obout $6-\mathrm{m}$ cubes.

\subsubsection{SRL TRANSPLUTONIUM WASTES}

Wastes from the Savannah River Loboratory (containing principally americium, curium, and californium) are placed in $0.6 \mathrm{~m}$ square by 1 to $1.2 \mathrm{~m}$ long concrete boxes before burial. These boxes weigh about $450 \mathrm{~kg}$. The wastes originate primarily in glove boxes and process cells. Most of the waste is combustible and the radiation level at the surface of the concrete box is generally in the range of 10-1000 mrem/hr. This waste mokes up about seven percent of the waste moterial buried.

\subsubsection{LARGE EQUIPMENT DIRECTLY BURIED IN TRENCHES}

Prior to 1966 large items of process equipment having significant transuranium contamination were enclosed in wooden or metal boxes and buried directly in trenches without concrete encopsulation. At present this proctice is permitted only for those items of process equipment that have been substantially decontaminated of transuranium materials before burial. In general, this equipment has a relatively high external radiation level from fission product contamination. This waste makes up about five to six percent of all the waste buried through 1970 .

\subsubsection{RETRIEVABLE 208-LITER DRUMS}

Drummed wastes received from off-site are presently stored in the Savannah River burial ground. These waste containers (approximately 11.2 percent of the waste buried through 1970) are in relatively good physical condition and may be considered retrievoble for a period of at least several years. 


\subsection{MISCELLANEOUS RADIOACTIVE WASTE ${ }^{23}$}

In aditition to the waste sources discussed obove, certain miscelloneous radioactive waste sources exist at SRP. Most of the locations of miscelloneous waste disposal are marked or are within controlled areas. These include locations containing rodioactivity from spills, equipment failure, etc., but not locations containing activity from ongoing operations. Table D-6 presents those areas which are TRU-contaminated.

\subsection{FUTURE WASTE GENERATION ${ }^{23}$}

The estimated annual generation rate of transuranium solid waste under the present and proposed policies are summarized in Table D-7. The waste forms generally reflect use of the retrievable criterio for waste with TRU control greater than $10 \mathrm{nCi} / \mathrm{g}$. 
TABLE 0-6

MISCELLANEOUS RADTOACTIVE WASTE IN SOIL 23

\begin{tabular}{|c|c|c|c|c|c|c|}
\hline \multirow[b]{2}{*}{ Date } & \multirow[b]{2}{*}{$\begin{array}{c}\text { Lacation \& } \\
\text { Erief Description }\end{array}$} & \multirow[b]{2}{*}{$\begin{array}{r}\text { Disposal } \\
\text { Area }\left(\mathrm{fr}^{2}\right) \\
\end{array}$} & \multirow[b]{2}{*}{$\begin{array}{l}\text { Treatment of Area } \\
\text { After Release }\end{array}$} & \multicolumn{2}{|c|}{ Remaining } & \multirow[b]{2}{*}{ Iype Waste } \\
\hline & & & & $\begin{array}{l}\text { Volume } \\
\left(\mathrm{ff}^{3}\right)\end{array}$ & $\begin{array}{c}\text { Curle } \\
\text { Content }\end{array}$ & \\
\hline 2/54 & $\begin{array}{l}\text { Plutonium solution } \\
\text { released thru the } \\
\text { F-Area saniltary } \\
\text { sower system from } \\
\text { Euilding 22I-FB } \\
\text { Lino }\end{array}$ & $\begin{array}{l}2 \times 10^{3} \\
\text { outside F Aroo }\end{array}$ & $\begin{array}{l}\text { Residue from treated } \\
\text { sewoge (Bullding } \\
607-\text { IF) deposited } \\
\text { ce } \\
\text { in trench and } \\
\text { covered }\end{array}$ & $10^{3}$ & $<0.02$ & Pu \\
\hline $6 / 69$ & $\begin{array}{l}\text { Curium-244 aerosol } \\
\text { reloosed from } \\
\text { Bulliding } 773-A \\
\text { cell } 122 \text { exhoust } \\
\text { stack of the High } \\
\text { Level Caves }\end{array}$ & $1 \times 10^{5}$ & None & - & 0.02 & $\mathrm{C}_{m-244}^{\alpha, p r i m a r i l y}$ \\
\hline$|2 / 7|$ & 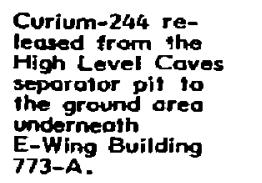 & $1 \times 10^{3}$ & None & - & 6 & cam-244h primarily \\
\hline
\end{tabular}




\section{TABLE D-7}

ESTIMATED ANNUAL GENERATION RATE

OF TRANSURANIUM SOLID WASTE AT SRP ${ }^{23}$

\begin{tabular}{|c|c|c|c|c|c|}
\hline & \multirow{2}{*}{$\begin{array}{l}\text { Waste } \\
\text { Cotegory }\end{array}$} & \multicolumn{3}{|c|}{ Radioactivity (Ci) } & \multirow{2}{*}{$\begin{array}{l}\text { Volume } \\
\left(\mathrm{m}^{3}\right)\end{array}$} \\
\hline & & Pu-239 & Pu-238 & $\mathrm{Cm}-244$ & \\
\hline I. & $\begin{array}{l}\text { Cardoord boxes for } \\
\text { direct trench burial }\end{array}$ & $10^{-4}$ & $10^{-4}$ & -- & 500 \\
\hline 2. & $\begin{array}{l}\text { Burial of drummed } \\
\text { waste in concrete } \\
\text { culverts }\end{array}$ & $\begin{array}{c}180 \\
(3000 \mathrm{~g})\end{array}$ & $\begin{array}{l}1,400 \\
(85 \mathrm{~g})\end{array}$ & - & 650 \\
\hline 3. & $\begin{array}{l}\text { Large equipment in } \\
\text { monolithic concrete } \\
\text { pours }\end{array}$ & 40 & 180 & -- & 65 \\
\hline \multirow[t]{2}{*}{4.} & $\begin{array}{l}\text { SRL } 0.6 \times 0.6 \times 1 \mathrm{~m} \\
\text { concrete boxes }\end{array}$ & 20 & - & 12,000 & 300 \\
\hline & TOTAL & $\begin{array}{l}240 \\
(4000 \mathrm{~g})\end{array}$ & $\begin{array}{l}1,600 \\
(100 \mathrm{~g})\end{array}$ & 12,000 & 1,515 \\
\hline
\end{tabular}




\section{TABLE OF CONIENIS}

Section Poge

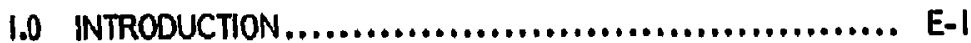

2.0 LOS ALAMOS SCIENTIFIC LABORATORY (LASL) ........... E-2

3.0 MOUND FACILITY $\ldots \ldots \ldots \ldots \ldots \ldots \ldots \ldots \ldots \ldots \ldots \ldots \ldots$ E-8

4.0 OAK RIDGE RESERVATION $. . . \ldots \ldots \ldots \ldots \ldots \ldots \ldots \ldots \ldots \ldots . . . \ldots$ E-13

4.1 Introduction ...................................... E-13

4.2 Oak Ridge National Laboratory (ORNL)................. E-14

4.3 Oak Ridge Y-12 Plant ............................... E-25

4.4 Oak Ridge Gaseous Diffusion Plant $(\mathrm{K}-25)$.............. E-26

5.0 ROCKY FLATS PLANT (RFP) ....................... E-30

5.1 Introduction ...................................... E-30

5.2 Waste Types, Characteristics, and Amounts .............. E-34

6.0 PADUCAH GASEOUS DIFFUSION PLANT................... E-45

6.1 Burial Facilities ..................................... E-45

6.2 Operating Proctices................................. E-47

7.0 PORTSMOUTH GASEOUS DIFFUSION PLANT ............... E-48

7.1 Burial Facilities ..................................... E-48

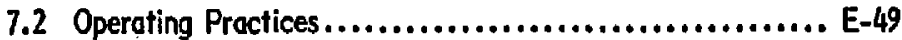

7.3 Waste Generation..................................... E-49

8.0 FEED MATERIALS PRODUCTION CENTER (FMPC).......... E-50

8.1 Introduction ...................................... E-50

8.2 Storoge Facilities................................. E-50

8.3 Operating Practices................................. E-5!

8.4 Waste Generation................................. E-52

9.0 NIAGARA FALLS SITE............................... E-53

9.1 Introduction ....................................... E-53

9.2 Open-Land Disposal Facilities.......................... E-53

9.3 Other Focilities ................................... E-54

10.0 WELDON SPRING SITE ............................. E-55

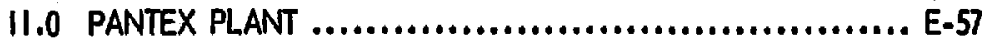




\section{TABLE OF CONTENTS, CONT.}

Section Page

12.0 SANDIA LABORATORIES (SL)......................... E-58

12.1 Introduction ....................................... E-58

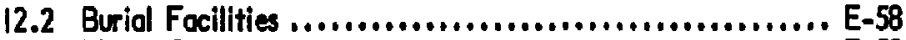

12.3 Waste Generation..................................... E-59

13.0 NEVADA TEST SITE (NTS) ........................... E-60

13.| Introduction ........................................ E-60

13.2 Storoge Focilities................................... E-60

13.3 Disposol Facilities ................................... E-61

13.4 Woste Generotion.................................. E-62

14.0 ARGONNE NATIONAL LABORATORY (AiNL)............... E-63

15.0 OTHER DOE SITES $\ldots \ldots \ldots \ldots \ldots \ldots \ldots \ldots \ldots \ldots \ldots \ldots \ldots . . . \ldots \ldots$ 


\subsection{NTRODUCTION}

The purpose of this Appendix is to present the best available information on other Department of Energy (DOE) focilities which generate and/a bury/store TRU-contaminated or potentially TRU-contaminated waste. The information presented is somewhat sketchy and possibly outdated, but represents the best ovailable dato taken from literature available to the researchers and personal conversation by investigotors. 


\subsection{LOS ALAMOS SCIENTFIC LABORATORY (LASL)}

\section{I INTRODUCTION}

The Los Alamos Scientific Laborotory is located in north-central New Mexico on the Pajarito Platea, west of the Rio Grande, on the eastern slopes of the Jemez Mountains. LASL has used shallow land burial for disposal of solid radioactive waste since the mid-1940s. The ixulk of the material consists of room-generated trash. A variety of special disposal operations has been performed, ranging from the shaft burial of a cylinder containing a few grams of tritium-contaminated solution to the demolition and burial of intire buildings. Currently, there are three active locotions (areas A, G, and T) for disposal at LASL. ${ }^{17}$ All solids contaminated with radioactivity are buried on-site at LASL. Contaminoted aqueous liquids ore treated to produce solids for on-site storage. Contaminated organic liquids are either burned (low-activity level) or jellied (high-activity level) to form a "solid" for on-site storage.

Waste generated of LASL is pockaged to provide safe handling and transport to the disposal site. With the exception of tritium wastes, the packaging is not intended to provide containment after burial. Most of the low-activity trashtype woste is compacted and baled prior to burial.

"Room-trash"-type wastes generated at the LASL DP-West plutonium focility are tested for radioactivity and properly segregated for burial or storage. This same practice is followed for similar types of waste generated at the LASL R\&D facilities where tronsuranic material is worked with. Distinctively hazardous and radioactive wastes, such $\alpha$ contominated laboratory chemicals and reactive metals, are properly packaged and disposed of in shafts and are immediately covered. The solids are categarized below according to how they are buried. ${ }^{18}$

LASL utilizes both storcge focilities and disposal focilities. There ore four types of storage focilities - storage shed, storage trench, cask storage trench and o corrugated metal pipe storage trench - which we located in area $G$ and area $T$. Disposal facilities include both disposal trenches and shafts. 


\subsubsection{STORAGE FACILITIES ${ }^{17}$}

The storage shed located in area $G$ is a metal building $(12.2 \mathrm{~m}$ in length $\times 4.6 \mathrm{~m}$ in width $\times 3.7 \mathrm{~m}$ in height) which serves as a temporary doveground storage area for drums and fiberglass-coated crates containing retrievoble TRU wastes. Maximum storage spoce ovailable is for about 250 (208-liter) drums or $25(1.2 \mathrm{~m}$ in length $\times 1.2 \mathrm{~m}$ in width $\times 2.1 \mathrm{~m}$ in height) fiberglass crates. Once o sufficient number of drums and crates have been accumulated in this shed, the drums are coated with a corrosion inhibitor and the crates are sealed with fiberglass and then all are ploced into the retrievable storage trench.

Also located in area $G$, the retrievable storage trench is $9.1 \mathrm{~m}$ wide, $122 \mathrm{~m}$ long, and $7.6 \mathrm{~m}$ deep with a 1:4 slope entrance ramp and an asphalt-lined floor. Sumps of the low point in the trench collect all water entering the trench as 0 result of rain or snowmelt. Waste packoges are stacked in the trench to within I-2 m from the surface, and the stack is then covered with $1.9 \mathrm{~cm}$ plywood and completely encased with a reinforced vinyl material. Finally, the waste stack is covered with $1.2 \mathrm{~m}$ of backfill.

Wastes ploced in the trench are limited to I g Pu-238 per 208-liter drum, $100 \mathrm{~g}$ of other TRU per I14-liter drum, $200 \mathrm{~g}$ of other TRU per 208-liter drum, or $175 \mathrm{~g}$ per $\mathrm{m}^{3}$ to a maximum of $350 \mathrm{~g}$ per crate.

Wastes contaminated with Pu-238 in excess of $1 \mathrm{~g}$ per drum or with U-233 with high gamma radiation are stored in concrete casks and placed into shallow trenches ( $40-80 \mathrm{~m}$ long by $2.8 \mathrm{~m}$ deep). The outside of each cask is coated by the manufacturer wh a bitumin epoxy material and is cooted a second time with on asphalt roofing compound. The casks are placed vertically in a trench, and the trench is backfilled almost to the top of the cask.

Two 114-liter drums of waste each containing up to a maximum of $40 \mathrm{~g}$ each of Pu-238 or $200 \mathrm{~g} \mathrm{U}-233$ are placed inside each cask. The cask lids are sealed with roofing tar. When a portion of a trench is filled, corrugated galvanized sheet metal is used to cover the trench over the tops of the casks, and the trench is backfilled to ground level and mounded 0.5 to $1.0 \mathrm{~m}$ above ground level. 
Two trenches containing 120 casks hove been filled to date (1977), and a third trench has been started. Room is ovailable for five additional trenches.

The corrugated metal pipe (CMP) storage trench located in area $T$ is used for the disposal of retrievable cement paste containing plutonium and americium. This paste is pumped into $0.75-\mathrm{m}$-diameter by $6.1-\mathrm{m}$-long corrugated metal pipe sections. Prior to filling, these pipes ore placed in a trench opproximately $6 \mathrm{~m}$ deep by $70 \mathrm{~m}$ long by $7.3 \mathrm{~m}$ wide. An uncontaminated cement plug $0.3 \mathrm{~m}$ thick seais the bottom of eoch pipe. Once filled, the pipes are sealed with onother 0.3m-thick cement plug. After the filling and sealing. the pipes are covered with backfill. The trench is obout 33 percent full. towever, the generation of retrievable cement paste is expected to end by mid-1978. ${ }^{17}$

\subsubsection{SOLIDS IN WASTE TRENCHES}

Most small solid articles contaminated with radicactivity are put into $0.03 \mathrm{~m}^{3}$ steel foot-operated rubbish bins with polyethyiene bag liners. If a s!ightly larger volume is needed $0.06 \mathrm{~m}^{3}$, corrugated cardboard cortons lined with plastic bogs are used. When these plastic liners are ful, they are sealed and collected either in $0.34 \mathrm{~m}^{3}$ plastic bags or in the cordboc $\mathrm{J}$ baxes which are also sealed. Other containers, such as 3.8-liter, 19-liter, 114-liter, and 208-liter steel cans or drums, are used for special situations. The large bags, boxes, and other containers are placed in steel transportable waste bins. The bins are picked up by special trucks and taken to the contaminated waste dispasal areo for discharge. Large contaminated solic items are covered as necessary to prevent spread of contamination during sinipment and transported separately to the disposal area. This miscelloneous bagged and boxed waste makes up about twothirds, currently, of the waste buried at LASL. Over 90 percent is contaminated with plutonium. Dewatered sludge from the low-level liquid waste treatment plant is put into 208-liter steel drums and hauled to the disposal area.

Disposal trenches are used for the disposal of low-activity nonretrievable radioactive wastes. These wastes include contaminated trash from laboratory areas, failed equipment, and solid residues from liquid waste treatment. Wastes are packaged in plastic bogs, cartboard boxes, or wooden crates. 
In the disposal area, trenches about $9 \mathrm{~m}$ deep, $30 \mathrm{~m}$ wide, and $150 \mathrm{~m}$ long with on excovated volume of about $3.4 \times 10^{4} \mathrm{~m}^{3}$ are dug. The ends are sloped for ease of access by vehicles. Wastes are carried by truck into the pit where they are dumped or set into place. Penetrating radiation readings on the package surfaces range from essentially zero to about $0.6 \mathrm{mrem} / \mathrm{hr}$ with $\mathrm{n}$ average of about 0.1 $\mathrm{mrem} / \mathrm{hr}$. When the waste has accumulated to 0 depth of about one meter, it is covered with about $0.3 \mathrm{~m}$ of dirt and compacted. Layers are continued until the pit is filled to within one meter of the surfoce, then dirt is placed on top, compacted and leveled.

\subsubsection{SOLIDS IN WASTE SHAFTS}

Deep shafts, augered into the volcanic tuff, are used for the disposal of high beta-gamma waste, tritium waste, contaminated animal tissue, cement paste, and classified contaminated waste.

Small items that are known to contoin somewhat larger amounts of radioactivity, particulaly beta-gamma radiation, are put into vertical shafts or holes in the ground and covered at $0.9 \mathrm{~m}$ intervals. These shafts are $0.9 \mathrm{~m}$ in diameter and 9 $m$ deep. In some cases the shaft is lined with $0.15 \mathrm{~m}$ of concrete and the waste is covered with concrete or asphalt. Since 1956, any waste containing a significant quantity (milligram) of plutonium has been buried separately in special shafts or holes.

Since mid-1968, the dewatered sludge from one liquid waste disparal facility and an americium roffinate (opproximately 6,050 liter/month containing obout

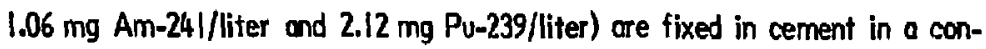
tinuous process and pumped through an underground pipeline to deep holes located in on abandoned waste disposal area obout $46 \mathrm{~m}$ away from the cementing facility. These holes or wells are 1.8 to $2.4 \mathrm{~m}$ in diameter and 7.6 to $20 \mathrm{~m}$ deep of both areas $G$ and $T$. They are filled with waste up to $1 \mathrm{~m}$ from ground surface or up to where the allowable level is reached. No more than $500 \mathrm{~g}$ of fissile material moy be disposed of in a shaft, and radiation doses at the shaft surface cannot exceed $100 \mathrm{mR} / \mathrm{hr}$. Whenever doses are exceeded, bockfill is 
added to reduce the dose. When the shaft is filled with waste, excovated turf is added to fill void spoces, a final I $\mathrm{m}$ concrete plug is poured, and the concrete is mounded above the shaft surface to provide a final seal with proper trainage. Before mid-1968, the americium raffinate was fixed in cement by a batch process in 208-liter drums which were hauled by truck to the waste pits. Most of the americium discarded is in this cemented product.

\subsubsection{WASTE GENERATION}

Reductions of 20-25 percent in the volume of wastes have been accomplished through a combination of required generator-site waste management standard operating procedures, as well as through control of materials entering radioactive work areas. Similarly, a large reduction in the volume of wastes placed in retrievable storage has resulted from better assay and segregation techniques, Rough estimates of the solid wastes contaminated with transuranics expected to be generated annually of LASL are shown in Table E-I. The current and expected annual rate of waste disposal at LASL is about $4000 \mathrm{~m}^{3} /$ year, which contains $8 \mathrm{KCi}$ of mixed fission and activation products and $8000 \mathrm{~kg}$ of uranium. The rate of TRU storage is $510 \mathrm{~m}^{3} /$ year, which contains $6.3 \mathrm{~kg}$ of transuranic elements. This compares fovorably to the 1974 data which indicated on annual burial of 32,020 curies in $4071 \mathrm{~m}^{3}$ of solids including binding agent. I Plutonium (primarily Pu-239) amounted to about $150 \mathrm{~g}$ and about $5 \mathrm{~kg}$ prior to provisions for retrievable storage. 
TABLE E-I

ESTIMATES OF FUTURE ANNUAL GENERATION OFTRU-CONTAMINATED SOLID WASTE AT LASL ${ }^{18}$

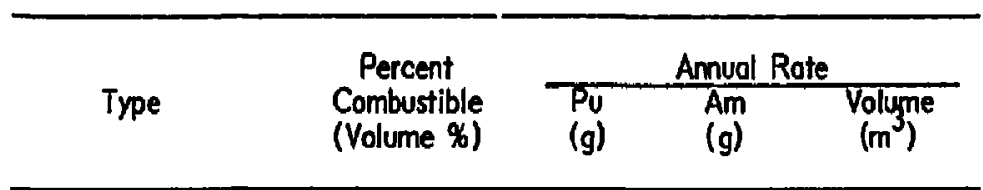

Bagged and boxed miscelloenous solid articles

Dewatered sludge from woter treatment

Cemented sludge and americium raffinate

TOTAL
60

0

30 trace 255

0

150

75 340

200

75

4,125 


\section{MOUNDFACLITY}

\subsection{WASTE GENERATION, CHARACTERISTICS, AND AMOUNTS}

Unclassified contaminated solid wastes generated by the Mound Facility are shipped to commercial burial sites of West Volley, New York (presently closed), or Morehead, Kentucky, for burial, while classified wastes were shipped to Oak Ridge, Termessee (ORNL). All TRU waste has been shipped to INEL since FY 1975. + 63 The polonium (on alpho emitter) and plutonium contaminated solid wastes generated of Mound con be put into five categories: Pu-238 low-level woste (LSA), Pu-238 high-level waste (non-LSA), solidified-clariflocculatorsludge (non-LSA), absorbed Pu-238 acid and caustic wastes (non-LSA), Po-210 low-level waste (LSA), and Po-210 high-level waste (non-LSA). The discard limits for Pu-238 are shown in Table E-2. The quantity of plutonium discarded renged from $45 \mathrm{~g}$ in FY 1966 to $1120 \mathrm{~g}$ in FY 1970 (Table E-3). ${ }^{18}$

\subsubsection{PU-238 LOW-LEVEL WASTE ${ }^{18}$}

The Pu-238 low-level waste is composed of contaminated equipment, floor sweepings, used plastic shoecovers, discarded clothing, poper towels, swipes, cleaning rags, blotter paper, etc., from rooms in which glove box and hot cell operations are conducted. Less than $0.35 \mathrm{mCi}$ Pu-238 per $\mathrm{m}^{3}$ is associated with this class of waste. About 60 vol $\%$ is collected and shipped in crates and about 40 vol \% in trums. Drums are the preferred containers for all waste types. Crates are used only for items that cre too large for drums.

\subsubsection{PU-238 HIGHLEVEL WASTE ${ }^{18}$}

The Pu-238 high-level waste consists of miscellaneous burnable and nonburnable solids (metal, plostic, glass, etc.) from glove boxes and hot cells used in plutonium production. As shown in Table E-2, burnables have less than $0.110 \mathrm{~g}$ of Pu238 per 3.78-liter corton, nonburnables less than $0.511 \mathrm{~g}$ per 3.78-liter corton, and glass filters less than $0.613 \mathrm{~g}$ per one $25.4 \mathrm{~cm}$ filter. Generally, this waste is collected in 3.78-liter cardoard cortons with a plastic costing on the inside 


\section{TABLE E-2}

DISCARD LEVELS OF PU-238 AT MOUND FACILITY $(1970)^{18}$

\begin{tabular}{|c|c|}
\hline Residue & Pu-238 Discard Level ${ }^{(0)}$ \\
\hline Bumobles & $0.110 \mathrm{~g}$ per 3.78 liter con \\
\hline Nonburnables & 0.511 g per 3.78 liter con \\
\hline lon exchange raffinate & $0.006 \mathrm{~g} /$ liter \\
\hline Evoporator condensate & $0.006 \mathrm{~g} / \mathrm{liter}$ \\
\hline Caustic bubbler and scrubber solution & $0.012 \mathrm{~g} /$ liter \\
\hline Wash solution & $0.006 \mathrm{~g} /$ liter \\
\hline Filtrate solution & $0.013 \mathrm{~g} / \mathrm{liter}$ \\
\hline Spent resin & $0.358 \mathrm{~g}$ per 3.78-liter cen \\
\hline Glass filters & $0.613 \mathrm{~g}$ per one $25.4 \mathrm{~cm}$ filter \\
\hline In-line filters & $0.461 \mathrm{~g}$ per one $25.4 \mathrm{~cm}$ filter \\
\hline Drummed residues & 1.85 g per 208-liter drum \\
\hline
\end{tabular}

a. A typical isotopic composition of the Pu-238 is:

$\begin{array}{ll}\text { Pu-238 } & 80.94 \% \\ \text { Pu-239 } & 15.26 \% \\ \text { Pu-240 } & 2.88 \% \\ \text { Pu-241 } & 0.79 \% \\ \text { Pu-242 } & 0.12 \% \\ \text { Pu-236 } & 1.2 \mathrm{ppm}\end{array}$




\section{TABLE E-3}

\section{QUANTITIES OF TRU-CONTAMINATED}

SOLID WASTE GENERATED IN FY 1970 AND EXPECTED TO BE GENERATED THROUGH FY 1975 AT MOUND FACILITY', 18

\begin{tabular}{|c|c|c|c|}
\hline \multirow[b]{2}{*}{ Category } & \multirow{2}{*}{$\begin{array}{c}\text { Fy } 1970 \\
\text { Generotion } \\
\begin{array}{c}\text { Volume } \\
\left(\mathrm{m}^{3}\right)\end{array}\end{array}$} & \multicolumn{2}{|c|}{$\begin{array}{c}\text { Expected Generotion } \\
\text { Through FY } 1975 \\
\end{array}$} \\
\hline & & $\begin{array}{l}\text { Volume } \\
\left(\mathrm{m}^{3}\right)\end{array}$ & $\begin{array}{c}\text { Anrual } \\
\text { Averoge } \\
\left(\mathrm{m}^{3}\right)\end{array}$ \\
\hline Pu-238 low-level waste ${ }^{(a)}$ & 1,398 & 8,500 & 1,700 \\
\hline Pu-238 high-level waste ${ }^{(b)}$ & 299.7 & 1,700 & 340 \\
\hline Solidified-ciariflocculator-sludge ${ }^{(c)}$ & 287.1 & 1,700 & 340 \\
\hline Absorbed Pu-238 acid and coustic ${ }^{(\mathrm{c})}$ & 381 & 700 & 140 \\
\hline
\end{tabular}

a. About 90 vol $\%$ combustibles.

b. About 75 vol \% combustibles.

c. Nonconbustibles. 
surface. Three cartons are sealed in a PVC bag as they are removed from the production line. Four of these sealed units, i.e., 12 cartans, are placed in a $114-$ liter steel dum. However, 208-liter drums and plywood crates are used for larger items such as contaminated equipment and glove boxes. Large items usually are filled with self-foaming plastic and placed in a crate which is lined with a polyethylene sheet. The open spoce in the crate is then filled with the self-foaming plastic.

\subsubsection{SOLIDIFIED-CLARIFLOCCULATOR-SLUDGE ${ }^{18}$}

The class of waste called solidified-clariflocculator-sludge is generated when sludge from the contaminated wastewater treatment focility is mixed with cement. The sludge contains the barium, calcium, and iron salts formed as well as the flocculating agent and activated charcoal added during the scovengingprecipitation treatment of the contaminated wastewater from drains, sinks, showers, the loundry, etc. The sludge containing 30 to 35 wt $\%$ solids is mixed with 11 to $22 \mathrm{~kg}$ of Portland cement in a 114 -liter steel drum. Less than $3.53 \mathrm{Ci}$ Pu-238 per $\mathrm{m}^{3}$ is associated with this waste.

\subsubsection{ABSORBED PU-238 ACID AND CAUSTIC WASTE ${ }^{18}$}

Absorbed Pu-238 acid and caustic waste are generated when ocidic and caustic solutions from the Pu-238 production lines are reacted with and absorbed by a pulverized cloy. In the treatment process, 45 liters of acidic or caustic solution are mixed with 110 liters of ground dried clay in a 110 -liter polyethylene jug (DOT Specification 2S) which is held within a 125-liter steel drum (DOT Specification (7H). The jug is outgassed for 24 hours with acidic solutions and eight hours with the caustic solutions before sealing. The radioactivity associated with this waste is less than $700 \mathrm{mCi}$ per $\mathrm{m}^{3}$.

\subsubsection{PO-210 LOW-LEVEL WASTE ${ }^{18}$}

The Po-210 low-level waste category consists of contaminated equipment, floor sweepings, used plastic shoe covers, discarded clothing, paper towels, swipes, 
cleaning rags, etc., from rooms in which glove box and hot cell operotions for polonium production are carried out. The Po-210 content of this waste is less then $0.35 \mathrm{mCi}$ per $\mathrm{m}^{3}$. The waste is collected and shipped in 114-liter steel drums (DOT 17H); 208-liter steel drums (DOT 17C); and plywood crates (DOT 19A or 19B).

\subsubsection{PO-210 HIGH-LEVEL WASTE ${ }^{18}$}

The Po-210 high-level waste is generated in the glove boxes and hot cells : sed in polonium production. It consists of the contaminated metal, glass, plastic, cloth, poper, etc., removed from the boxes and cells. The polonium associated with these materials amounts to less than $1,765 \mathrm{Ci} / \mathrm{m}^{3}$. The waste is collected in $114-$ liter steel drums. This urum is shipped in a 208-liter steel drum used os an overpock.

The volume of TRU-contaminated solid waste generated in 1970 and estimated through FY 1975 is given in Table E-3. 


\subsection{OAKRIDGE RESERVATION}

\subsection{INTRODUCTION}

Locoted in the west central portion of eastern Tennessee, the Oak Ridge Reservation is bounded on the northeast, southeast, and southwest by the Clinch River and on the nor thwest by Black Oak Ridge.

The 92-square-mile Oak Ridge Reservation was originally acquired by the Manhattan Project, U. S. Army Corps of Engineers, as a site for production focilities and muclear research, and a security buffer and safety zone were established around each plant within the Reservation. The original 23,877 hectores acquired in 1942 have since been reduced to aproximately 14,959 hectores through land transfers to the municipal government of Oak Ridge and to state and Federal agencies. 25

The allocation of land among the DOE users is as follows:

$\begin{array}{ll}\text { Administrative Unit } & \text { Hectares } \\ \text { Multiple Use } & 7,068 \\ \text { ORNL (X-10) } & 3,550 \\ \text { Y-12 } & 1,384 \\ \text { K-25 } & 1,910 \\ \text { CARL (UT-DOE) } & 1,047\end{array}$

Four seporate production and research facilities are operated within the reservation. They are Oak Ridge Notional Laboratory $(X-10)$, the Y-12 Plont, the Oak Ridge Gaseous Diffusion Plant (K-25), and the Comparative Animal Research Laboratory (CARL). Buffer zones are designated around each of the four facilities for health, safety, and future expmsion. Access to the reservation is limited primarily to public roods and visitor centers for reasons of health, safety, and national security. ${ }^{25}$ 


\subsection{OAK RIDGE NATIONAL LABORATORY (ORNL)}

Normal operations of ORNL generate up to 7.6 million liters per year of intermediate-level waste (ILWW) solution hoving an averoge activity concentration of a few hundredths of a curie per liter. This ILW solution is routinely neutralized with sodium hydroxide which precipitates those constituents of the waste solution that are insoluble in alkaline solution. These solids, which contain the bulk of the 5r-90 and the actinides that have been discharged to the waste system, setfle and accumulate in the waste storage tanks. The remaining liquid (supernate) is concentrated by evcoporation and since 1966 has been periodically disposed of by shale fracturing (a process for the fixation of the waste in $\mathrm{an}$ impermeable bedded shale formation at a depth of approximately 300 meters). Approximutely 300,000 liters of concentrated waste solution are disposed of annually. The current generation rate for sludge is doout 40,000 liters per yectr. About 1,500,000 liters of sludge hove accumulated from the operations of previous years and are presently held in various waste storage tanks. ${ }^{25}$

The concentrated waste solution is alkoline, the major chemical constituent is sodium nitrate and the predominant rodionuclide is $\mathrm{Cs}_{5} \mathrm{I} 37$ (doout $0.3 \mathrm{Ci} / 1$ ). This solution is one of three components of the $\mathrm{LW}$ to be processed in the proposed processing facility. The onticipated concentration of radionuclides in each of the three ILW streoms is given in Table E-4. The second ILW component is the sludge which would be diluted to a 12-percent-by-weight slurry to make it pumpable. The predominant radionuclide would be $9 r-90$. The third component of the ILW to be processed is an assumed waste from future operations at ORNL which is designoted as "pilot plant waste."

\subsubsection{LIQUID WASTE STREAM5 ${ }^{25}$}

Rodioactive liquid wastes are produced by a number of different research, development, and production programs of ORNL. These include such things as basic radiochemistry studies, development of reacto: fuel reprocessing methods, production of rodioisotopes for medical, industrial and research uses, production of transuranium isotopes for research, operation of research reactors, etc. The 

liquid radioactive wastes from these and similar activities are collected in underground stainless steel tanks ranging in size from o few hundred liters to several thousand liters and located near the incividual facilities producing the waste. The wastes are made alkaline in the collection tanks by the addition of sodium hydroxide to reduce the corrosiveness. The callection tanks are periodically emptied by pumping the contents to one of six 645,000 -liter underground concrete central collection tanks. These tanks are frequently referred to as the "gunite" tanks because of the method that was used to construct them. The addition of sodium hydroxide to the raw waste causes some of the dissolved materials to precipitate from the solution and this precipitate settles to the bottom of the gunite tanks as a sludge. The sludge contains essentially all (s99\%) of the uranium and tronsuranium nuclides that might rave been in the liquid as well as some of the radioactive fission products such as $\mathrm{Sr}-90$. The sludge is one component of the ILW that is to be processed by the proposed solidification facility. The liquid obove the sludge is fed to $\mathrm{m}$ evaporator where it is concentrated by a factor of 20 to 30 and the concentrate is temporarily stored in one or more of the remaining gunite tanks. About 300,000 liters per year of concentrated woste solution is generoted of ORNL. Periodically, the accumulated concentrate is pumped to the shale fracturing focility in an adjacent valley, mixed with cement, and injected into a shale formation at on apjiroximate depth of 300 meters.

At the present time there is a construction program in progress at ORNL to modify the waste processing system described above. These modifications include the installation of a second ILW evoporator in parallel with the existing evaporator, installation of two 190,000-liter stainless steel tanks in a stainless steel lined underground vault to receive raw waste and feed it to the evaporator, installation of a 190,000-liter stainless steel tank to collect the ILW concentrate from the evoporators, installation of a new doubly contained central waste collection header, the installation of eight 190,000-liter stainless steel tanks for temporary storage of concentrate in $\mathbf{m}$ underground voult located adjacent to the proposed site for a new solidification facility and the installation of a doubly contained waste transfer line between the evaporator and the new waste storage tanks. 
When the construction currently in progress is complete, operation of the ILW collection and concentration system will be essentially the same as it is now except that the six gunite tanks will no longer be used. However, before these tanks can be put into a condition requiring minimal future surveillance, the sludge which has been accumulating since 1943 ( $(1,500,000$ liters) must be removed and immobilized in the proposed new processing focility. This represents a "one time only" tosk for the new focility since it is planned, once the proposed facility is built, to process sludge routinely rather than let it accumulate as it has in the past.

The proposed processing facility will be designed tu hondle three types of intermediate level radiocctive wastes. This ILW consists of:

I. Currently generated waste solution concentrote, which totals about 300,000 liters per year. This waste will be on alkoline salt solution (I $\mathrm{M} \mathrm{NaNO}_{3}$ and other minor constitvents). Generally, the major radionuclide (about 0.3 $\mathrm{Ci} /$ liter) is $\mathrm{Cs}-137$, while only 0.3 Ci/liter or less is $\mathrm{Sr}-90$. The major olpha activity is $\mathrm{Cm}-244$ from the heovy element production program; its concentration is about $0.3 \mathrm{~m} \mathrm{Ci} /$ liter. The long lived (greater than 30 years) alpha content of the waste concentrate, including the decoy products from short lived parent nuclides is less than $10 \mathrm{n} \mathrm{Ci} / g r a m$.

2. The sludges produced by the processing and handling operations of the last three decades that are currently stored in the gunite waste tanks. There are about 1,500,000 liters of these sludges. Analyses indicate that these sludges contain between 500,000 and $800,000 \mathrm{Ci}$ of Sr-90, between 60,000 and $90,000 \mathrm{Ci}$ of $\mathrm{Cs}_{-} 137,12,000 \mathrm{Ci}$ of $\mathrm{Cm}-244$ and 250 to $310 \mathrm{Ci}$ of Pu-239. Current planning onticipates that within the next few years these sludges will be resuspended and pumped to a processing focility. This waste stream, after resuspension and dilution for pumping, will have a specific activity of about $13 \mathrm{Ci} /$ liter of Sr-90. About 40,000 liter/year of currently generated sludge will also be processed. Its composition is expected to be similar to that of the sludge now in storage.

3. Future pilot plent wastes - Several pilot plant progroms that have been proposed for ORNL hove the potential for generating waste solutions with a higher specific activity than the ORNe intermediate level waste has had in the 
past. Some of these programs, such as the LMFBR spent fuel reprocessing plant, propose to include processes that will immobilize all waste streams that are generated. If the quantity and concentration of radionuclides are high, however, the wastes would be stored in existing doubly contained waste storoge lonks until the isotopes with short half-lives had decayed (at least five years) and the specific activity of the residual isotopes would be low enough so that only moderately thick shielding would be needed in the processing facility. After this time these wastes or some part of them could be processed by the ORNL ILW system.

\subsubsection{OPERATIONAL HISTORY 25}

The existing disposal focility was built in 1963 and a series of experimental waste injections was made in 1964 and 1965 to demonstrate the feasibility of the process. After the end of these experimental injections the focility was converted into an operational focility for the routine disposal of concentrated intermediate level waste solution. This solution is an alkaline solution that is approximately $\mathrm{IM}$ in $\mathrm{NaNO}_{3}$. The predominant radionuclide is $\mathrm{Cs}-137$; its specific acitivity is about $0.3 \mathrm{Ci} /$ liter. About 300,000 liters/year is produced.

A number of modifications and improvements were made at this time to improve various phases of the plant operation. Two additional waste storage tanks with a combined capacity of 180,000 liters were installed. This increased the total onsite waste storoge capacity to 340,000 liters. A dry solids weigh tank was installed to improve the dry solids blending system.

From 1966 to 1970 , this modified facility was used for a series of seven injestions that disposed of $3,750,000$ liters of waste grout containing $350,600 \mathrm{Ci}$ of $\mathrm{Cs}-137$ and $26,500 \mathrm{Ci}$ of $\mathrm{S}-90$. Some of the parameters of these injections are given in Table E-5.

\subsubsection{TRU WASTE OPERATIONS ${ }^{18,63}$}

Solid radioactive waste generated at this site is collected in suitable containers and tronsported to one of the burial graunds, where they are stored or disposed of. There are six buriol grounds at ORNL. Three of these are inactive, and two 


\section{TABLE E-5}

INJECTION PARAMETERS FOR ROUTINE ORNL DISPOSAL OF WASTE SOLUTION 25

\begin{tabular}{|c|c|c|c|c|c|c|c|}
\hline $\begin{array}{c}\text { Injection } \\
\text { No. }\end{array}$ & Date & $\begin{array}{c}\text { Depth } \\
(\mathrm{m})\end{array}$ & $\begin{array}{l}\text { Waste } \\
\text { Volume } \\
\text { (liter) }\end{array}$ & $\begin{array}{l}\text { Sr-90 } \\
\text { (Ci) }\end{array}$ & $\begin{array}{c}\text { Cs- } 137 \\
(\mathrm{Ci})\end{array}$ & $\begin{array}{c}C m-244 \\
(C i)\end{array}$ & $\begin{array}{c}P u-239 \\
\text { (Ci) }\end{array}$ \\
\hline \multicolumn{8}{|c|}{ Experimental Injections } \\
\hline $1-7$ & $\begin{array}{c}1964 \\
\text { to } \\
1965\end{array}$ & $\begin{array}{l}285 \\
\text { to } \\
264\end{array}$ & & 1,436 & 5,237 & -- & -- \\
\hline
\end{tabular}

Operational Injections

$\begin{array}{lrrrrrrr}\text { ILWIA } & 1966 & 264 & 136,300 & 3 & 19,50 & \text { NA* } & \text { NA } \\ \text { ILWIB } & 1966 & 264 & 98,400 & & & & \\ \text { ILW2A } & 1967 & 261 & 325,500 & 1,050 & 58,500 & \text { NA } & \text { NA } \\ \text { ILW2B } & 1967 & 261 & 234,700 & & & & \\ \text { ILW3A } & 1967 & 261 & 117,300 & 9,000 & 17,000 & \text { NA } & \text { NA } \\ \text { ILW3B } & 1967 & 261 & 196,800 & & & & \\ \text { Water Test } & 1967 & 258 & -- & & & & \\ \text { ILW4A } & 1968 & 258 & 90,900 & 4,300 & 51,900 & \text { NA } & 1.10 \\ \text { ILW4B } & 1968 & 258 & 235,350 & & & & \\ \text { ILW5 } & 1968 & 254 & 306,600 & 56 J & 69,400 & \text { NA } & 1.15 \\ \text { ILW6 } & 1969 & 254 & 300,400 & 8,900 & 89,000 & \text { NA } & 0.24 \\ \text { ILW7 } & 1970 & 254 & 314,200 & 2,747 & 44,833 & 19.2 & 1.77 \\ \text { ILW8 } & 1972 & 251 & 275,200 & 45 & 28,000 & 0.20 & 0.13 \\ \text { ILW9 } & 1972 & 251 & 258,500 & 231 & 23,400 & 6.51 & \text { None } \\ \text { ILWI0 } & 1972 & 251 & 320,800 & 1,330 & 18,800 & 26.67 & 0.37 \\ \text { ILWII } & 1972 & 251 & 286,750 & 1,100 & 23,500 & 155.74 & \text { None } \\ \text { ILWI2 } & 1975 & 248 & 97,300 & 1,324 & 12,752 & 1.02 & \text { None } \\ \text { ILWI3 } & 1975 & 248 & 306,600 & 3,368 & 35,750 & 17.83 & 0.03 \\ \text { ILWI4 } & 1975 & 248 & \underline{314,000} & \underline{2,874} & \frac{30,592}{3.58} & 3.58 & \text { None } \\ \text { Total ILW } & & & 4,218,600 & 36,766 & 523,377 & & \end{array}$

$N A=$ not anolyzed 
(burial grounds 5 and 6) are currently in use. Burial ground 3 is now only used for above-ground storage of contaminated equipment that may be reusable.

Estimated sources of transuranium-solid waste at ORNL are summarized in Table E-6. Approximately $1.76 \times 10^{5} \mathrm{~m}^{3}$ of radioactive solid waste were buried in ORNL burial grounds through 1972. About 60 percent of this waste was generated of ORNL while the remainder was shipped from off-site (including Argonne National Laboratory). Most of the ORNL waste was transported to the burial ground using only femporary containment such as plasric and sprayed coatings. Wastes from off-sile were generally shipped in steel drums and wooden crates. In general, wastes were not segregated with respect to waste type.

At present, ORNL burial grounds are used almost exclusively for ORNL wastes, which are generated of the rate of about $4,250 \mathrm{~m}^{3} /$ year. Wostes contoining negligible quantities of transuranium nuclides continue to be buried in a relatively unretrievable fashion. Low radiation level, transuranium solid waste is packaged in either 208-liter steel (or stainless steel) drums or steel boxes and stored either in a building or a roofed, rock-filled trench to facilitate retrievability. High radiation level transplutonium wastes from the Transuranium Facility are collected and stored in the rock-filled trench as potentially retrievable, sealed concrete containers. Other high radiation level transuranium wastes are packogert in stainless steel containers and stored in marked, steel-lined auger holes.

ORNL classified locally generated radioactive waste intended for burial as follows:

- The fissile-alpha waste corresponding to transuranium waste is defined by DOE 05II-2I as the solid waste that exceeds the concentration of 10 microcuries of alpho particle activity per kilogram of waste rsociated with fissionable isotopes. This cotegory inclwa-s, primarily, americium, curium, and plutonium, as well as some U-235. This material must be handled so as to permit retrieval within 20 years. These materials originated primarily in the transuranium-processing facilities and in fuel reprocessing research and development operations. Betagamma emitting nuclides are often included with these 
TABLE E-6

ESTIMATED SOURCES OF TRANSURANIUM SOLID WASTE AT ORNL ${ }^{0,18}$

\begin{tabular}{|c|c|c|c|c|c|}
\hline \multirow[b]{2}{*}{ Trpe } & \multirow[b]{2}{*}{$\begin{array}{l}\text { Percent } \\
\text { Burnable }\end{array}$} & \multicolumn{2}{|c|}{ Quantity in Storage } & \multicolumn{2}{|c|}{ Annual Generation Rate } \\
\hline & & $\begin{array}{l}\text { Volume } \\
\left(\mathrm{m}^{3}\right)\end{array}$ & $\begin{array}{l}\text { Alpha } \\
\text { Radioactivity } \\
\text { (Ci) }\end{array}$ & $\begin{array}{l}\text { Volume } \\
\left(\mathrm{m}^{3}\right)\end{array}$ & $\begin{array}{c}\text { Alpha } \\
\text { Radioactivity } \\
\text { (Ci) }\end{array}$ \\
\hline $\begin{array}{l}\text { Retrievable Steel Drums } \\
\text { Low radiation level }\end{array}$ & 50 & & & $169^{(d)}$ & $30(\mathrm{Pu}-239)$ \\
\hline $\begin{array}{l}\text { Retrievable Steel Boxes } \\
\text { Low radiation level }\end{array}$ & 20 & 0 & o & $42^{(d)}$ & $6(P u-239)$ \\
\hline $\begin{array}{l}\text { Steel Drums and Boxes } \\
\text { High radiation level }\end{array}$ & 50 & o & $\mathbf{0}$ & $28^{(d)}$ & 5 (Pu-239) \\
\hline Concrete Casks ${ }^{(a)}$ & 550 & 280 & $200(\mathrm{Cm}-244)$ & $100^{(d)}$ & $80(\mathrm{Cm}-244)$ \\
\hline $\begin{array}{l}\text { Solid Waste for Burial } \\
\text { Low radiation level }\end{array}$ & so & $\begin{array}{c}113,300^{(b)} \\
(283,300)^{(c)}\end{array}$ & $300(\mathrm{Pu})$ & 3,335 & $<1$ \\
\hline $\begin{array}{l}\text { Solid Waste for Burial } \\
\text { High radiation level }\end{array}$ & so & $18,300^{(b)}$ & $100(P u)$ & $(84,500)^{835}(c)$ & $<0.03$ \\
\hline Tank Form Sludges & 0 & $(7,300)^{1,275}(c)$ & 300 (Pu-239) & & \\
\hline
\end{tabular}

a. Waste from contamination zones or known to contain $>3531 \mu \mathrm{\mu i} / \mathrm{m}^{3}$ of transuranium nuclides.

b. Quantity as charged.

c. Estimated volume if the waste were prepared for off-site shipment.

d. Since 1970, these packages are stored to facilitate retreivability. 
muclides and in very heavy elements spontaneous fission often occurs with production of neutrons. Certain beryllium isotopes or deuterium will emit photoneutrons. These special situations all create unique problems and demand special methods for handling of the fissile alpha wastes.

- The fissile non-alpha waste is a solid waste that contair. one gram or more of non-alpha particle emitting fission. able materials regardless of concentration, or more than 35.7 grams per cubic meter (one gram per cubic font) of the same material regardless of quantity. Sources of these wastes include various metallurgical operations and other onalytical and research and development operations. The objective of handling this waste is to prevent the criticality during or after burial. It is not a direct rediation hazord.

The volume of waste buried at ORNL since the fire of 1961 is about $87,500-n^{3}$ in the area of 7.5 hectares. Transuranium- and uranium-contaminated $w$ stes buried af ORNL before 1974 amount to about $685 \mathrm{~m}^{3}$ and fissionable material and contaminated waste about $200 \mathrm{~m}^{3}$. Not all of the transuranium waste can be considered reasonably retrievable.'

Fissile alpha-particle emitting wastes (TRU wastes) have on alpho particle radiocctivity in excess of 10 microcuries per kilogram (10 nanocuries per gram) originating from fissionable isotopes. This kind of waste, when accompanied by $n$ high level of beta, gamma, or neutron emmission, is packaged at the point of origin in reinforced concrete casks. Records are kept of the location and content of each of the trenches containing this material.

\subsubsection{STORAGE FACILITIES ${ }^{17}$}

TRU wastes are stored in a variety of ORNL focilities ranging from trenches in which material is placed and covered with soil, to stainless-steel-lined shafts, to 85 percent below-ground buildings for 208- or 114-liter metal drums. The selection of the focility depends on the intensity of the radiation involved.

TRU waste contoining high levels of beta-gammo or neutron emissions is placed in reinforced concrete casks and stored in unlined trenches. Casks are 
segregated by trench according to their flammable and non-flammable waste content. Once filled, the trenches are bockfilled with soil. TRU waste containing less than $200 \mathrm{mR} / \mathrm{hr}$ is stored in stainless steel drums and held in a staging area until a sufficient number of them is ovailable for storage of the Retrievable Waste Sturage Facility, Building 7826. Building 7826 is a one-story reinforced concrete and concrete-block structure epproximately $11.5 \mathrm{~m} \times 17.4 \mathrm{~m}$ $\times 4 \mathrm{~m}$ high, There are 24 pits or cells which con each accommodate 64, 208-liter dums. About 85 percent of the structure is below grode.

TRU waste with high bockground readings is stored in stainless-steel-lined shafts of various diameters (ranging from 20.3 to $50.8 \mathrm{~cm}$ ). The liners are provided with concrete collars and stainless steel caps. Spacing between shafts is not less than $0.9 \mathrm{~m}$, and the transuranic isotope content is limited to $200 \mathrm{~g}$ per shoft. The shafts are filled with stainless steel containers of waste and then are capped with a removable concrete plug. The contents of each shaft are recorded.

Facilities 7827 and 7829 contain stainless steel wells which are used for the storage of TRU waste containing high beta-gamma activity. Facility 7829 contains 30 wells; 15 of them are $4.5 \mathrm{~m}$ deep, and the other 15 are $3 \mathrm{~m}$ deep. The dicmeter of these wells ronges from 20.3 to $76.2 \mathrm{~cm}$.

\subsubsection{DISPOSAL FACILITIES}

Non-TRU waste and general radioactive waste are generally disposed of in unlined trenches and/or shofts. Trenches are approximately $15 \mathrm{~m}$ in length, $3 \mathrm{~m}$ wide, and 3-4.5 $\mathrm{m}$ deep. They are graded to slope toward one end. A corrugated metai casing, $15.2 \mathrm{~cm}$ in diameter, is inserted vertically into the trench and is used as a monitoring well. Once filled to within $0.9 \mathrm{~m}$ of grade, the trench is backfilled with soil.

Shafts vary in diameter $(0.6$ to $1.0 \mathrm{~m})$ and depth (less than $6 \mathrm{~m}$ ). A minimum spacing of $0.9 \mathrm{~m}$ in between shafts is maintained, and the radioactive content is limited to $200 \mathrm{~g}$ per shaft. Once filled, the shafts are capped with concrete. 
Three settling basins have been used in past operations at ORNL. These basins are waste pond no. 1, waste pand no, 2, and the homogeneous reactor test settling basin. Only waste pand no. $I$ is still used and serves as an equalization basin for laboratory process waste prior to treatment in the ion-exchange focility.

From 1957 to 1976, waste pond no. 2 served as a settling basin for the effluent from the lime-soda-clay treatment plant. Sediment samples token after its decommissioning indicated that bottom sediments at this pond contain approximately $5 \mathrm{Ci}$ of $\mathrm{Pu}-239$ and $\mathrm{Pu}-240$ and vorious fission products. The concentration of radionuclides in the bottom sediments of waste pond no. $I$ is expected to be higher then that in waste pond no. 2. However, the bottom sediments in this pond have not been sompled, and consequently no estimate of their rodionctive content is available.

The settling basin was used for disposal of low-activity liquid waste generated in the 7500 area. The bosin is no langer in service and has been filled and covered with asphalt. No records of its contents are ovailable.

Pits and trenches were used for the disposal of intermediate-level liquid waste. A total of four pits and three trenches was used in this operation until 1965. Radionuclide seepoge from one trench and one pit wos deticted in the earlier days of this operation, and both trench and pit were closed. Approximately $181,680 \mathrm{~m}^{3}$ of liquid waste containing 1 million curies was disposed of in these pits and trenches.

Burial grounds 1 and 2 cover on area of about 2 ho and were closed in 1945. These areas were used primarily for the disposal of contaminated trash, Iaboratory equipment, and other items that were discarded. Burial ground 3 was opened in 1946 and used until 1951 for underground disposal of waste. Burial ground 4 covers a total area of 9.3 ha and wos used until 1959 for the disposal of alpho-and beta-gamma-contaminated waste.

Burial ground 5 has been used for the disposal of all types of wastes including TRU woste; however, most of the material that has been disposed of in this 
burial ground is considered as general radioactive waste such as mixed fission products, depleted uranium, filter media, and equipment that could not be economically decontaminated. The 27.5-ho burial ground 6 was opened in 1969 and is used for disposal of waste in trenches and shafts.

For TRU woste, an Authorization for Storage of Radioactive-Contaminated Solid Waste and a Record of Transactions of Source and Special Nuclear Materials are required before the material is transported to the storage site. The three types of containers used for the pockaging of this woste are concrete casks, stainless steel drums, and stainless steel capsules. Concrete casks are placed in trenches, and shielded drums and copsules are placed in shofts. Casks containing flammable waste are separated from those containing nonflammable waste. Once filled, the trenches are backfilled with $0.9 \mathrm{~m}$ of soil. 17

Low-activity waste is stored in drums and does not require shielding. The drums are shipped by truck and stacked in building 7823 until a sufficient number of them is accumulated. Then they are transferred to building 7826 for final storage. Non-TRU waste is disposed of in unlined shofts and covered with $0.9 \mathrm{~m}$ of soil. Unpackaged bulk material containing less then $1 \mathrm{~g} / \mathrm{ft}^{3}$ of fissionable isotopes is disposed of in unlined trenches. General rodioactive waste disposal is accomplished by depositing the waste in trenches or shafts. Once the trench is filled to within $0.9 \mathrm{~m}$ of the surface, it is backfilled with soil.

High-activity general radioactive waste with a surface radiation in excess of 200 $\mathrm{mR} / \mathrm{hr}$ is packaged in stainless steel drurns and transported in shielded casks for disposal in shafts. A total of $18,540 \mathrm{~m}^{3}$ of this radioactive contaninated waste containing $62.6 \mathrm{KCi}$ of radioactivity has been disposed of at ORNL. The current rate of disposal is approximately $3000 \mathrm{~m}^{3} /$ year. 17

\subsection{OAK RIDGE Y-12 PLANT ${ }^{17}$}

The Oak Ridge Y-12 Plant (427-ha plant crea) is located in Bear Creek Valley obout $4.8 \mathrm{~km}$ from Oak Ridge, Tennessee. The low-activity radioactive waste disposal sites are also located in Bear Creek Valley about $2.9 \mathrm{~km}$ west of the moin plant site. The classified disposal areo is located within the main plant site. 
Low-activity radioactive waste is disposed of in trenches $(5.5 \mathrm{~m}$ deep $\times 7.9 \mathrm{~m}$ wide) at burial grounds 1-A and 2-C. Filled trenches are covered with soil, leveled, and grass-seeded. Burial ground I-A is used primarily for the disposal of depleted uranium-contaminated materials such as particulate filfers, metal dums, and mixed-metal machine turnings. About $9.0 \times 10^{6} \mathrm{~kg}$ of these materials is disposed of in this burial ground annually. Waste disposal, compaction, and sealing processes presently require the use of land at a rate of 0.04 ha per year.

Materials contaminated with enriched uranium and natural thorium are disposed of in burial ground $2-C$ at a rate of $4.5 \times 10^{5} \mathrm{~kg}$ per year. The current land use for this waste disposol operation is $\mathbf{0 . 0 4}$ ho per year. Burial ground 2-B is used for the storage of pure, depleted uranium. About $7.3 \times 10^{5} \mathrm{~kg}$ of uronium is buried in trenches ( $4.5 \mathrm{~m}$ deep by $4.0 \mathrm{~m}$ wide) at this site.

Classified moterials such as forms made from uranium and thorium are disposed of in trenches (5.8 $\mathrm{m}$ deep $\times 2.4 \mathrm{~m}$ wide) at the classified disposal area. For security reasons, the materials are covered with soil the some day they are placed in the trench. A total of $2.3 \times 10^{5} \mathrm{~kg}$ of these contaminated materials is buried annually of this site.

Records and descriptions are maintained on each disposal operation; they include the volume, radionuclide content, type of containers, location, and personnel safety measures token. No further information is presently available concerning these waste materials.

\subsection{OAK RIDGE GASEOUS DIFFUSION PLANT (K-25)}

The Oak Ridge Gaseous Diffusion Plant is situated on a 259-ho areo in eastern Tennessee. Its primary purpose is the enrichment of uranium hexofluoride in the uranium-235 isotope. No high-level radioactive waste is stored or disposed of at K-25. The majority of the low-activity waste buried or stored at this site is material contaminated with uranium and with traces of Np-237, Pu-239, and Tc99. 
There are five low-activity radioactive woste sites at K-25: the old classified burial ground, new classified burial ground, K-33 contaminated waste burial ground, K-722 scrap metal yard, and K-1407-C retention basin. Three of the five sites are land burial grounds, but only one is still active. The fourth site is an active above-ground storage area where noncontaminated and contarninated scrap metal is stored. The fitth site is on active retention basin for radioactive and nonradioctive sludges.

The old classified burial ground covers 1.5 ha and has on overage depth $\mathrm{L} f$ about 9.1 $\mathrm{m}$. Due to the lack of accurate records, no good estimate of the radioactivity of the moterials disposed of at this site can be made. However, it con be deduced that most of the material buried is uranium-contaminated with only trace quantities of transuranics and/or fission products. 17

The new classified burial ground was built in 1975 to dispose of classified radioactive and nonradioactive material and covers on areo of 8.9 ha. Waste is buried in trenches $4.5 \mathrm{~m}$ deep and $30.5 \mathrm{~m}$ long. Each trench is completeiy filled, covered with soil, and grass-seeded before excavating another trench. At the present time, only $0.1 \mathrm{Ci}$ of uronium is buried of this site, along with troce quantities of TRU and/or fission products.

The K-33 contaminated waste butial ground was utilized for the disposal of unclassified solid radioactive waste. The area occupied by the buried materials is only 0.08 ho of the I.I ha initially committed for this site. As of July 1975, this area contains about $1007.5 \mathrm{~m}^{3}$ of uranium-contaminated materials and $68.8 \mathrm{~m}^{3}$ of thorium-contaminated materials. ${ }^{17}$ Small amounts of other uranium compounds, thorium compounds, contaminated uranium hexofluoride cylinders, beryllium chips, boron, etc., are also buried at this site. The use of this burial ground was discontinued, effective March 1976. The total predicted rodioactivity of all these materials is approximately $14.1 \mathrm{Ci}$. The $\mathrm{K}-33$ burial ground contains o total of 62 graves, ranging from trenches $(3.4 \mathrm{~m}$ wide $\times 0.9 \mathrm{~m}$ in diameter $\times 36.9 \mathrm{~m}$ in length) to shafts $(3.7 \mathrm{~m}$ deep $\times 0.9 \mathrm{~m}$ in diameter $)$. 
The K-722 scrop metal yard covers 8.9 ho of land for the storage of scrap metal. The scrap metals consist of steel, stainless steel, aluminum, copper, nickel, and alloys. Two of the 8.9 ha are set aside for the storage of malal that has been exposed to uranium materiols or shows alpha or beta-gamma activity on the surface. It is estimated that $2.7 \times 10^{6}$ to $4.5 \times 10^{6} \mathrm{~kg}$ of contaminated scrop metal are stored in this site. No estimated quantity of radionuclides associated with these materials is ovailable.

The $\mathrm{K}-1407-\mathrm{C}$ retention basin (213.4 $\mathrm{m} \times 15.2 \mathrm{~m} \times 1.8$ in diameter) is primarily used in the disposal of rodioactive and nonrodioactive sludges, such as dredgings from various holding ponds. Since its construction in 1973, this bosin has accumulated a volume of about $1146.9 \mathrm{~m}^{3}$ of dewatered sludge. The total radioactivity of the material contained in this basin is estimated to be about $18 \mathrm{Ci}$, primarily consisting of uranium compounds and TC-99. Currently the use of this basin is restricted to the periodic storoge of lime sludges. Rodioactive wastes are not routinely deposited in this basin.

In addition to the retention basin, K-25 has three holding ponds: K-1407-B, K901-A, and K-1007-B. The K-1407-B holding pond $(118.9 \mathrm{~m} \times 45.7 \mathrm{~m} \times 1.8 \mathrm{~m}$ in diameter) is mainly used for the settling of uranium compounds discharged from the decontamination and recovery facility. As of April, 1977, $3 \mathrm{Ci}$ of radioactivity wos estimated to be in this pond, mainly consisting of low-activity uranium and technetium compounds. The $\mathrm{K}-90 \mathrm{l}-\mathrm{A}$ holding pond has a length of approximately $426.7 \mathrm{~m}$, a width ranging from $1 \mathrm{~m}$ to nearly $137.2 \mathrm{~m}$, and a depth ranging from o few centimeters to about $3 \mathrm{~m}$. Its primary purpose is the settling of lime solids from the water treatment facility. in the post, this pond was used for the disposal of rodioactive and nonradioactive waste from an intermittent cylinder-puncturing operation. No estimate of the radioactivity of this pond is available. Some uranium and trace quantities of TC-99 have been detected.

The K-1007-B pond ( $548.6 \mathrm{~m} \times 137.2 \mathrm{~m} \times 1.5 \mathrm{~m}$ in diameter) is mainly used for $\mathrm{pH}$ control, through dilution, of small quantities of acidic and caustic wastes discharged from the laboratories and for the settling of solids from chemical operations and storm drains. Although the estimated radioactivity of the pond is 
not available, bottom sediment sainples have been analyzed to contain minor amounts of uranium and technetium compounds.

\subsubsection{OPERATING PRACTICES}

Since the old classified burial ground and the K-33 contaminated waste burial ground are no longer used for waste disposal, there ore no operating practices assaciated with their use, except for routine landscaping maintenance.

Material disposed of in the new classified burial ground is properly surveyed for radiation contents. Accurate records of the radiation contents and disposal locations for specific radioactive items ore kept. Material disposed of at the K722 scrap yard is classified as clean or contaminated by health physics personnel and stored in a designated area of the yard according to its classification. The current use of the $\mathrm{K}-1407-\mathrm{C}$ retention basin is restricted to radioactive and nonrodiooctive sludge disposal. 


\subsection{ROCKY FLATS PLANT (RFP)}

\subsection{INTRODUCTION}

The Rocky Flats Plant, which is operated for the Department of Energy by Atomics International, is a key producer of plutonium parts for nuclear weapons. It is located opproximately 10 miles south of Boulder, Colorado, and 16 miles northwest of Denver. Construction of the present plant complex consisting of some 75 buildings and structures, was started in 1951, and the plant was put into operation during 1953.64

RFP handles many kilograms of plutonium each year. The work, which is performed in glove boxes, currently generates, annually, more than $5,230 \mathrm{~m}^{3}$ of solid waste contaminated with plutonium.

\section{I.I LIQUID WASTES ${ }^{64}$}

Liquids contaminated with plutonium ae transferred is a process waste treatment plant. There the plutonium and other chemical contaminants are removed by carrier precipitation as solids for transfer to DOE-approved storage at INEL.

Most liquids are freated at least three times by ne 'trolization and the addition of ferric hydroxide to form a carriei precipitate. Tiis precipitate is collected on drum filters, removed as a sludge, mixed with diy cement to absorb free liquids, and placed in 208-liter drums. Liquids containing hydrochloric acid or complexing rgents are processed seporately by mixing the liquids with portland cement to form a solid in 208-liter drums. Liquids containing acids are neutralized prior to mixing. Organic solutions and oils are also blended with an absorbent to form a solid in the 208-liter drums. 
Effluent from treated liquid, which is liw in radioactivity but high in soluble chemical contaminants, is evaporated in solar ponds or by forced evaporation. Salts from the evaporation cre packaged in 208-liter drums. The previously releosed processed aqueous waste is now being retained in a holding pond until construction of a new waste treatment facility is completed.

\subsubsection{RADIOACTIVE SOLID WASTE ${ }^{18}$}

In its handling of plutonium and other radionuclides, the Rocky Flats Plant generotes radjoactive scrop, or residue, and radioactive waste. Scrap is material that can be recycled for productive use; radioactive scrap contains plutonium or enriched uranium that is economically desirable to recover. Wasta, on the other hand, has no recoverable value. Radioactive waste is not economically worth treating to recover the plutonium or uranium in it.

A total of about 5,230 cubic meters of plutonium contaminated waste is currently generated annually. Nearly 3,270 cubic meters of this total is packoged and shipped to on off-site retrievable storage location. This is considered TRU waste, which is waste with more than 10 nanocuries per gram ( $\mathrm{nCi} / \mathrm{g}$ ). Approximately 1,960 cubic meters is pockaged and shipped to an off-site non-retrievable location; this in non-TRU (NTRU) waste that hos less than 10 nanocuries of plutonium per gram. 64

Currently', the Rocky Flats operation generates about $20 \mathrm{~kg}$ of waste plutonium annually. The accumulated (through 1975) plutonium in the INEL burial site amounts to about $500 \mathrm{~kg}$ of which about $120 \mathrm{~kg}$ is retrievable storage.

\subsubsection{WASTE COLLECTION 18}

Removing solid woste from glove boxes involves transferring the waste through a glove-box opening into a plastic bag or sleeve clamped to the opening. The bag is then twisted, taped closed, and cut awuy. If the bag is left out for even a short period, it is placed in a second bog for added protection. These procedures are 
supplemented by forced, down-draft ventilation; individually fitted respiratory protestion for all personnel; close rodiotion monitoring surveillance; and protection from external radiation sources. Beccuse of its origin, all waste of this type is considered by the Department of Transportation (DOT) to be of NOS (Not Otherwise Specified) activity (formerly HSA or High Specific Activity). LSA (Low Specific Activity) waste has less thon 0.1 microcurie of plutonium per gram of waste; NOS waste contains more thon $0.1 \mu \mathrm{Ci} / \mathrm{g}$.

Other contaminated solid wastes result from materials such as clothing, poper used by employees in process - controlled oreas (but outside glove boxes), and surgeons' gloves; they are designated low specific activity (LSA) if no significont $X$ - or gamma radiation is noted by radiation monitoring surveys and if no measurable plutonium is indicated by drum-counting techniques. These techniques involve detectors that identify and quantify the radioactive elements in each durn containing contaminated waste.

\subsubsection{WASTE PACKAGING ${ }^{18}$}

Most radioactive wastes are sorted and packaged in 208-liter steel drums manufactured under a quality control program to ensure compliance with DOT specifications. A thick-walled polyethylene dum liner is used to contain TRU wastes inside the drum for retrievable storage. The polyetñylene liner provides added resistance to corrosion from the contents, increases resistance to tear or puncture, and is a means of containment even if the steel drum corrodes. The plutonium content of each drum is determined by counting neutrons and garmma radiation.

Some wastes such as glove boxes, large equipment, and construction materials are too large to fit into a 208-liter drum. These items are disassembled to reduce the volume, cleaned to remove plutonium, and packaged into $1.9 \mathrm{~cm}$ thick plywood boxes. For retrievable storoge, the boxes are coated with fire-retardant 
and fiberglass-reinforced polyester. These boxes are manufactured under a quality control program to ensure compliance with DOT specifications. Each item placed into a plywood box is monitored with a calibroted, portable, sodium jodide detector to detect any significont residual plutonium.

All primary containment packaging for contaminated waste is controlled by Guality Control Procedure Q-2000, "Radioactive Material Packaging Quality Assurance." 64

\subsubsection{WASTE SHIPPING ${ }^{18}$}

Rocky Flats uses rail cars and truck trailers to ship wastes of the present time to INEL (Idaho National Engineering Laboratory). Drums and uncaated boxes containing non-TRU waste, such as evaporator salts, sewage sludge, and material contaminated with depleted uranium and beryllium are trucked directly to INELL. All other drums have TRU woste; they are ploced in cargo containers that are loaded into ATMX rail cars, which are specially designed cars owned by DOE. All rail shipments go to the Transuranic Storage Areo where the cargo containers are unloaded. All coated boxes are also shipped by ATMX rail car.

\subsubsection{GENERAL}

Rocky Flats' operating policy places the respcrisibility for all wastes on the department that generotes the waste. The policy enforces a philosophy of eliminating and controlling wasis where the waste originates. Since 1970, the volume of solid, radioactive waste generated at Rocky Flats has been reduced from o rate in excess of $8,400 \mathrm{~m}^{3}$ per year to the present rate of slightly more than $5,200 \mathrm{~m}^{3}$ per year $\left(6,000 \mathrm{~m}^{3} \text { in } 1975^{1}\right)_{0}^{18}$

Rocky Flats is actively pursuing odditionol programs and focilities to further reduce the volume of solid, radioactive waste being generated and the omount of plutonium contained in wastes. Major reductions are expected when new scheduled chemical recovery and waste treatment focilities become operational. 
These facilities will remove more plutonium from the waste streams, provide for incineration of all combustibles, recover nitric acid for reuse, remove more water from the waste treatment sludges, and increase the density of evaporator solts.

\subsection{WASTE TYPES, CHARACTERISTICS, AND AMOUNTS 18}

Unclassified contaminated solid wastes generated by RFP are shipped to INEL for burial while classified wastes are shipped to Richlond, Washington. The volume of solid waste (contaminated with uranium or plutonium and americium) shipped doubled from about $3,700 \mathrm{~m}^{3}$ in FY- 1964 to about $7,650 \mathrm{~m}^{3}$ in FY- 1969 (see Table E-7) and nearly doubled again to about $11,350 \mathrm{~m}^{3}$, shipped in FY-1970 becouse of the waste generated in cleaning up after the fire in a plutonium production line in May 1969. The onnual volume shipped has decreased to about $5,230 \mathrm{~m}^{3}$ (1976). The activity shipped to INEL in these wostes varies depending upon programs being carried out (Table E-8). The plutonium (and americium) contaminated solid waste generoted at RFP can be put into eight categories: first stage sludge (non-LSA), second stage sludge (non-LSA), evaporator salts (LSA), cemented liquids (non-LSA), grease (non-LSA), line-generated waste (nonLSA), nonline-generated waste (LSA), and crated waste (non-LSA). Sorting or seyregation of contaminated waste at RFP is done mainly to facilitate measurement of radicactive content and to aid in the processing of the material.

\subsubsection{SOLIDS FROM THE WASTE TREATMENT PLANT ${ }^{64}, 18$}

First stage sludge, second stage sludge, evoporator salts, cemented liquids, and grease are generated in the waste treatment plant for radioactive liquids. Aqueous liquids of low radioactivity but high chemical content are sent either to the waste evaporator in the treatment plant or to solar evaporation ponds and then to the evaporator. The evaporator bottoms are sent to a double-drum dryer where the remaining water is removed. Water vapor from the evoporator and drum dyer go up the evaporator stack. The dried salts are drummed for shipment. Aqueous liquids of high radisoctivity and high chemical content are 


\section{TABLE E-7}

\section{CONTAMINATED ${ }^{(0)}$ SOLID WASTE SHPPED BY ROCKY FLATS FROMFY-64 TOFY-69 18}

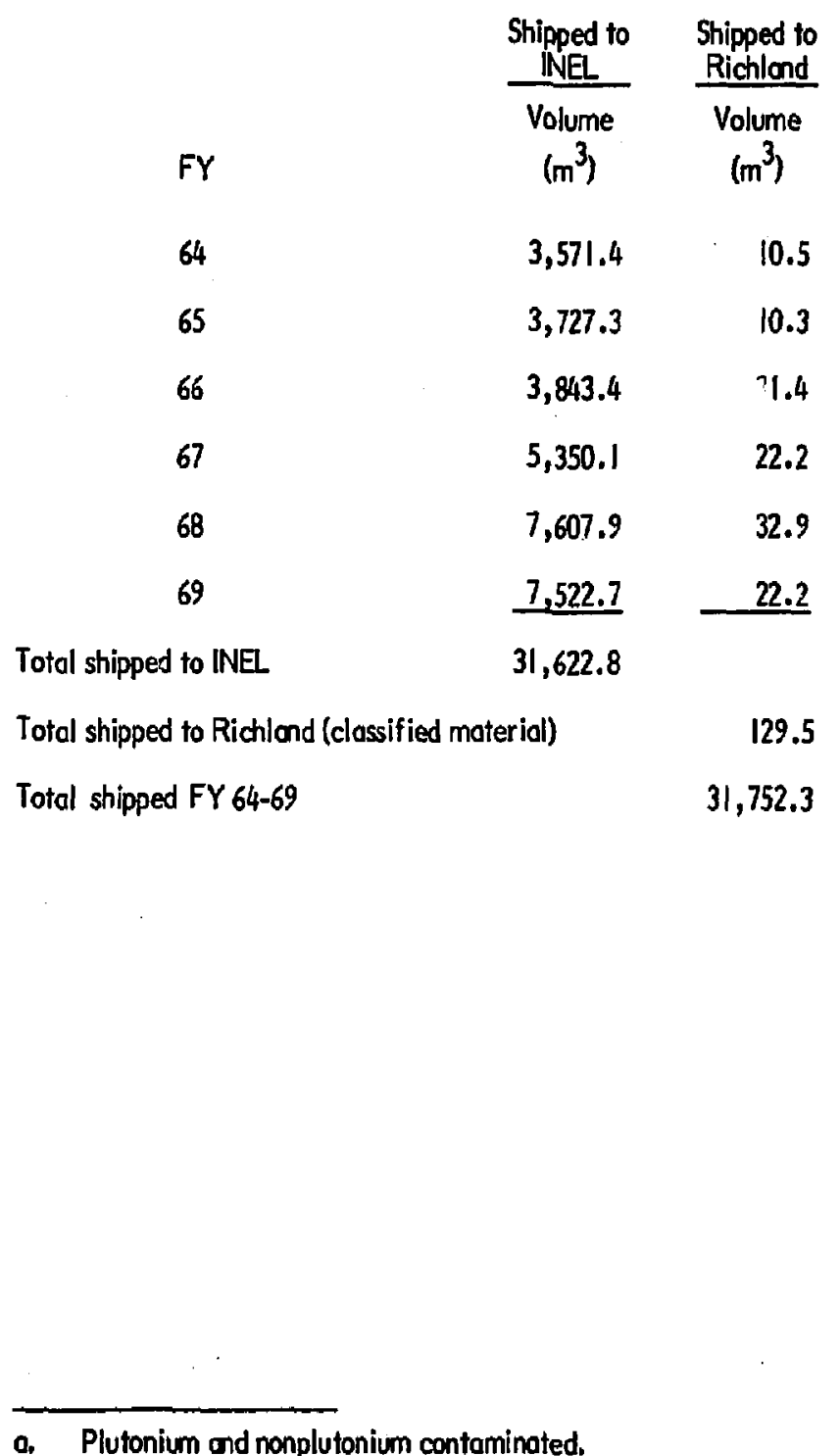

a. Plutonium and nonplutonium contaminated. 
II

TABLE E-8

ESTIMATE OF TRU ACTIVITY SHIPPED BY ROCKY FLATS PLANT TO INEL FOR STORAGE 18

\begin{tabular}{ccc} 
Year & $\begin{array}{c}\text { Pu-239 } \\
(\mathrm{g})\end{array}$ & $\begin{array}{c}\text { Am-241 } \\
(\mathrm{g})\end{array}$ \\
\hline 67 & 50,031 & 2,129 \\
68 & 46,486 & 1,778 \\
69 & 38,046 & 4,876 \\
\hline & & \\
\hline 67 & $(\mathrm{Ci}){ }^{(b)}$ & $(\mathrm{Ci})^{(0)}$ \\
\hline 69 & 4,622 & 6,813 \\
69 & 3,579 & 5,690 \\
& 2,930 & 15,603 \\
\hline
\end{tabular}

a. Bosed on: Am-24l at $3.2 \mathrm{Ci} / \mathrm{g}$

b. Plutonium Isotopic Composition and Alpha Radioactivity

\begin{tabular}{|c|c|c|}
\hline Isotope & Wt. $\%$ & $\mathrm{Ci} / \mathrm{g} \mathrm{Pu}$ \\
\hline $\begin{array}{l}P u-238 \\
P u=239 \\
P u-240 \\
P u-241 \\
P u-242\end{array}$ & $\begin{array}{r}0.009 \\
93.750 \\
5.857 \\
0.368 \\
0.016 \\
\end{array}$ & $\begin{array}{c}0.0015 \\
0.0575 \\
0.0133 \\
- \\
0.0000006 \\
\end{array}$ \\
\hline & 100.000 & 0.0723 \\
\hline
\end{tabular}


processed through two stages of decontamination in the treatment plant using a ferric hydroxide carrier precipitation process. The decontaminoted aqueous waste is combined with the low radioactivity-high chemical content waste and is processed in the waste evaporator mentioned above. The precipitate is removed from the supernatant liquid by vacuum filtration. The filter cakes are tummed for shipment as first and second stoge sludges. Aqueous liquids of high radioactivity but low chemical content are decontaminated in the second stage of the waste treatment plont. The precipitate is filtered and drummed for shipment as second stage sludge. Aqueous wastes containing complexing ogents are not amenable to the above precipitation process. They are discharged into lined drums filled with magnesio and cement to set up before shipment. These solids form the category called cemented liquids. (lon exchange resins are also cemented.) Organic liquids, primarily cutting oil plus carbon tetrachloride, are shipped to the waste treatment plant where they are mixed with calcium silicate to form a putty-like mass called grease. About 140 liters of organic waste is converted to grease per 208-liter drum used for shipment.

\subsubsection{LINE-GENERATED WASTES ${ }^{18}$}

Line-generated waste contains the bulk of the plutonium discarded and shipped for burial. This waste cafeyory is segregated at the point of generation according to type of waste material (Table E-9). The residues are segregated by type to aid in assaying for nuclear materials accounting and to focilitate processing, including incineration when necessary, to recover plutonium. The type of matrix has to be known to obtain a valid determination of plutonium content by the dum counter. Residues which contain more than the discard concentration of plutonium are processed as scrap to recover the plutonium. Residues which contain less then the discard concentration are discarded as linegenerated wastes.

\subsubsection{NONLINE-GENERATED WASTES ${ }^{18}$}

Wastes removed from a radioactive material processing area (other than a processing line) ore considered as contaminoted and ore collected in dums as 
TABLE E-9

\section{CATEGORIES AND DISCARD LIMITS AT THE ROCKY FLATS PLANT LINE-GENERAiED WASTE 18}

1

I]

\begin{tabular}{lc} 
Category & $\begin{array}{c}\text { Discard Limit } \\
(\mathrm{g} \text { Pu/g) }\end{array}$ \\
\hline Sweepings & 0.007 \\
Sludge & 0.007 \\
MgO Sond & 0.007 \\
ion Exchange Resin & 0.007 \\
Incinerator Ash & 0.007 \\
Sweepings Heels & 0.007 \\
Ash Heels & 0.007 \\
Glass and Ceramics & 0.0005 \\
Scorfed Molds & 0.00035 \\
Graphite Flow Residue & 0.002 \\
CWS Filter $(0.6 \times 0.6 \times 0.3 \mathrm{~m})$ & $24 \mathrm{~g} /$ filter \\
Dry Box Filters $(3.1 \times 3.1 \times 1.6 \mathrm{~cm})$ & $3 \mathrm{~g} / \mathrm{filter}$ \\
WWashables & $0.00 \hat{0} 06$ \\
Combustibles & 0.0007 \\
Miscelloneous Scrop Metal & 0.0003
\end{tabular}


nonline-generated solid waste. Drums indicating greater than $0.5 \mathrm{mr} / \mathrm{hr}$ at the surface are sent to the drum counter for assoying and possible plutonium recovery. Nonline-generated waste which shows less than $0.5 \mathrm{mr} / \mathrm{hr}$ at the surface of the drum is considered LSA waste and shipped as such.

\subsubsection{CRATED WASTES}

Items that are too large to be put into a durn are put into plastic lined plywood boxes or crates. These constitute the category called crated wastes.

Nonline-generated plutonium wastes are segregated from nonline-generated uranium wostes since they are generoted in separate buildings. However, until 1970 they were not kept separate in shipment or burial. Drums of all categories of non-LSA plutonium wastes are mixed in shipment and burial. A comprehensive breakdown of RFP waste discards for first stoge sludge, second stage sludge, evaporotor salts, and cemented liquids are given in Toble E-10; for grease in Table E-il; for line-generoted waste in Table E-12; for nonline-generated woste in Table E-13; and for crated Pu-contaminated waste in Table E-14 (based on 1967 evaluation). 
TABLEE-10

FIRST STAGE SLUDGE, SECOND STAGE SLUDGE, CEMENTED LIQUIDS, AND EVAPORATOR SALTS SHIPPED BY THE ROCKY FLATS PLANT INCY $1967^{(a), ~} 18$

\begin{tabular}{ccccc}
\hline & First Stage Sludge & & \multicolumn{2}{c}{ Second Stage } \\
\cline { 2 - 3 } \cline { 5 - 5 } $\begin{array}{c}\text { Date } \\
\text { (Quarter } \\
\text { CY 67) }\end{array}$ & $\begin{array}{c}\text { Volume } \\
\left(\mathrm{m}^{3}\right)\end{array}$ & & $\begin{array}{c}\text { Sludge } \\
\text { Volume } \\
\left(\mathrm{m}^{3}\right)\end{array}$ & $\begin{array}{c}\text { Miscelloneous } \\
\text { (b) }\end{array}$ \\
\hline Ist & 70.6 & & 46 & $\begin{array}{c}\text { Volume } \\
\left(\mathrm{m}^{3}\right)\end{array}$ \\
2nd & 48.9 & & 72.4 & 22.9 \\
3rd & 46.8 & & 71 & 6.9 \\
4th & $\underline{49.8}$ & & 62.2 & 7.5 \\
Total & 216.1 & & 251.6 & 3.7
\end{tabular}

\begin{tabular}{|c|c|c|c|}
\hline \multirow[b]{2}{*}{$\begin{array}{l}\text { Dote } \\
\text { (Quarter } \\
\text { CY67) }\end{array}$} & \multicolumn{2}{|c|}{ Cementing Facility } & Evaporator Salts \\
\hline & $\begin{array}{c}\text { Cemented Liquid } \\
\text { Volume } \\
\left(\mathrm{m}^{3}\right)\end{array}$ & 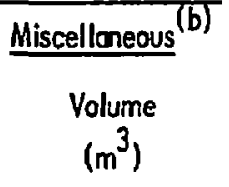 & $\begin{array}{c}\text { Volume } \\
\left(m^{3}\right)\end{array}$ \\
\hline Ist & 33.5 & 10 & 1.2 \\
\hline 2nd & 22.3 & 6.9 & 3.3 \\
\hline $3 r d$ & 5.6 & 6.2 & 72.8 \\
\hline 4 th & 16.7 & 7.7 & $\underline{175.3}$ \\
\hline Total & 78.1 & 30.8 & 262.6 \\
\hline
\end{tabular}

a. Total plutonium charged off in these four waste cotegories was $8.125 \mathrm{~kg}$.

b. Contaminated empty bottles used as containers 'or transporting solutions to the waste treatment building. 
TABLE E-II

GREASE SHIPPED BY THE ROCKY FLATS PLANT IN $1967^{18}$

\begin{tabular}{|c|c|c|c|c|c|}
\hline \multirow[b]{2}{*}{$\begin{array}{l}\text { Dote } \\
\text { (Quarter } \\
\text { (967) }\end{array}$} & \multicolumn{2}{|c|}{$\mathrm{CCL}_{4}$-Oil Generated } & \multirow{2}{*}{$\frac{\text { Shipped }^{(a)}}{\begin{array}{c}\text { Volume } \\
\left(\mathrm{m}^{3}\right)\end{array}}$} & \multicolumn{2}{|c|}{$\begin{array}{c}\text { Empty } \\
\text { Contaminated Drums }\end{array}$} \\
\hline & $\begin{array}{l}\text { Volume } \\
\text { (liter) }\end{array}$ & $\begin{array}{l}P u \\
(g)\end{array}$ & & $\begin{array}{l}\text { Drums } \\
\text { (No.) }\end{array}$ & $\begin{array}{c}\text { Volume } \\
\left(\mathrm{m}^{3}\right)\end{array}$ \\
\hline Ist & 19,190 & 263 & 20.4 & 627 & 130.5 \\
\hline 2nd & 21,725 & 199 & 338.3 & 440 & 91.6 \\
\hline $3 r d$ & 10,600 & 75 & 320.1 & 547 & 113.8 \\
\hline 4 th & $\underline{12,225}$ & $\underline{292}$ & 286.4 & $\underline{334}$ & 69.5 \\
\hline Total & 63,740 & 829 & 965.2 & 1,948 & 405.4 \\
\hline
\end{tabular}
a. The amount of grease shipped is much larger then the $\mathrm{CCL}_{4}$-oil waste gen-
erated becuose of back-log material. 
TABLE E-12

LINE-GENERATED WASTE SHIPPED BY THE ROCKY FLATS PLANT IN $1967^{18}$

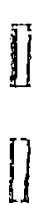

1

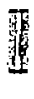

Material

Grophite

$88.5 \quad 21,211$

Sond, Slog, and Crucible

47.7

6,948

Insulation

65.8

$13,0 \mid 2$

Fire Brick

0.6

355

Resin

Scrap Metal

Glass

5.0

1,207

Washables

56.8

1,773

21.0

1,235

66.2

4,699

Combustibles

23.5

648

Line-Generated

9.0

344

Filters

6.0

592

Tontalum

1.9

169

Miscelloneous

17.1

2,164

Am-24l Waste

8.6

408

Am-244 Waste

1.8

113

Total

376.2

54,878 


\section{TABLE E-13}

NONLINE-GENERATED WASTE (FROM PU PRODUCTION AREAS) SHIPPED BY THE ROCKY FLATS PLANT IN $1967^{18}$

\begin{tabular}{cc}
$\begin{array}{c}\text { Date } \\
\text { (Quarter 1967) }\end{array}$ & $\begin{array}{c}\text { Volume } \\
\left(\mathrm{m}^{3}\right)\end{array}$ \\
\hline Ist & 309.1 \\
2nd & 280.8 \\
3rd & 282.5 \\
4th & 325.8 \\
Total & $1,198.2$
\end{tabular}


TABLE E-14

CRATED Pu-CONTAMINATED SOLID WASTE SHIPPED BY THE ROCKY FLATS PLANT IN $1967^{18}$

\begin{tabular}{|c|c|c|c|c|c|c|}
\hline \multirow[b]{2}{*}{$\begin{array}{c}\text { Date } \\
\text { (Quarter } \\
1967 \text { ) }\end{array}$} & \multicolumn{2}{|c|}{$\begin{array}{l}\text { Incinerator } \\
\text { Filters }\end{array}$} & \multicolumn{2}{|c|}{$\begin{array}{c}\text { Miscellaneous } \\
\text { Pu-Contaminated } \\
\text { Wostes }\end{array}$} & \multicolumn{2}{|c|}{$\begin{array}{c}\text { Total Crated } \\
\text { Pu-Contaminated } \\
\text { Wastes }\end{array}$} \\
\hline & $\begin{array}{c}\text { Volume } \\
\left(\mathrm{m}^{3}\right)\end{array}$ & $\begin{array}{l}P_{u} \\
(g)\end{array}$ & $\begin{array}{c}\text { Volume } \\
\left(\mathrm{m}^{3}\right)\end{array}$ & $\begin{array}{l}P u \\
\text { (g) }\end{array}$ & $\begin{array}{c}\text { Volume } \\
\left(\mathrm{m}^{3}\right)\end{array}$ & $\begin{array}{l}\text { Pu } \\
\text { (g) }\end{array}$ \\
\hline Ist & 23.4 & 510 & 93.5 & 313 & 116.9 & 823 \\
\hline 2nd & 66.3 & 482 & 77.4 & 264 & 143.7 & 745 \\
\hline $3 \mathrm{rd}$ & 62.4 & 671 & 81.3 & 230 & 143.7 & 901 \\
\hline 4th & 38.9 & 988 & 175.4 & 298 & 214.3 & $\underline{1,286}$ \\
\hline Total & 191.0 & 2,651 & 427.6 & 1,105 & 618.6 & 3,756 \\
\hline
\end{tabular}




\section{PADUCAH GASEOUS DFFUSION PLANT}

The current buriol of low-level radicactive waste at Paducah is within the 303-ho main plant site, which is located near Paducah, Kentucky.

\subsection{BURIAL FACILITIES ${ }^{17}$}

The primary radioactive waste burial area, $\mathrm{C}-404$, is $\mathrm{C}$ converted holding pond. The holding pond wos constructed with in on-grade tomped cloy bottom ond tamped clay lined dikes ( $1.8 \mathrm{~m}$ high) enclosing on areo of $0.5 \mathrm{ha}$. The pond was used in the disposal of uranium-contaminated magnesium fluoride slag and rejected uranium tetrafluoride.

This area is now covered with silty clay and is slightly mounded to facilitate runoff. Drummed uronium wastes are currently being placed on top of the backfilled pond. Once a sufficient number of drums are assembled, a clay cover will be placed over the drums.

The uranium burial ground, C-749, comprises on area of 0.3 ha and was used for the disposal of uronium-beuring scrap metal deemed undesirable for buricl in the old lolding pand area (primarily pyrophoric uranium metal in the form of sawdust, shavings, and tumings). Approximately 74 percent of this area has been utilized since the first burial on December, 1975. Scrap metal is placed inside on excovoted pit and covered with a 1.2-m soil cover.

The classified scrap burial yard, C-746F, is a fenced 0.7-ha plot. Disposal in this urea has utilized on orea of 0.1 ha. Items disposed of consist of nonrecoverable weapon components. These are placed in a pit $2.4 \mathrm{~m}$ jeep and then covered with a $1.2 \mathrm{~m}$ cover of soil. The only radioactivity acsocioted with this facility is a very smoll amount of tritium (less than $10 \mathrm{Ci}$ ).

Area $A$ (20.7 $\mathrm{m}$ in width $\times 83.8 \mathrm{~m}$ in length $\times 3-3.7$ in dianteter) is used for the disposal of miscelloneous noncombustible trash (excluding uranium scrap and 
contaminated materials or equipment). Aluminum and steel shavings from the machine shop and a limited anount of contaminated bulky equipment items have been buried here in the past. Approximately 85 percent of this area has been used. The used areas are covered with a $1.2-\mathrm{m}$ layer of compacted clay and gravel.

During the period of 1958 to 1962, areas B, C, and G were used to dispose of noncombustible trash and contaminated noncombustible moterial (except uranium scrap) and equipment. These areas comprise a total of 0.2 ha and were dug to a depth of 1.8 to $2.1 \mathrm{~m}$. Each pit was filled to about $0.9-1.2 \mathrm{~m}$ with waste and covered with $0.9-1.2 \mathrm{~m}$ of soil.

The concrete burial sites, areos D and $E$, comprise on areo of 0.03 ha, and small burial pits were excavated to a depth of $1.8-2.1 \mathrm{~m}$. Each pit contains about 9070 $\mathrm{kg}$ of concrete pieces resulting from the removal of the concrete bases of the vibrating recctor trays during May and June of 1960. The uranium-contaminated material buried in these pits was covered with about $0.9 \mathrm{~m}$ of suil.

The 0.06 ho which comprises area F-C-340 has been utilized for disposol of miscellaneous contaminated material and equipment and contaminated scrap metal. Material buried was covered with about $0.9 \mathrm{~m}$ of soil.

The contominated aluminum burial site, area J, has on area of about $0.04 \mathrm{ha}$. A pit was excavated to a depth of about $1.8 \mathrm{~m}$, ond the contaminated scrap metal buried in this pit consisted of about 100 to 150 drums of aluminum scrap metal in the form of nuts, bolts, efc. The contamination was primarily natural, depleted, and slightly enriched uranium corrosion products with trace quantities of neptunium and plutonium. The concentration of TRU nuclides is estimated to be orders of magnitude below the level that requires retrievable storage. ${ }^{17}$ The pit was covered with $0.9 \mathrm{~m}$ of soil.

Areo $L\left(55.2 \mathrm{~m}^{2}\right)$ contains a single contaminaied iodine cold trop (UF ${ }_{6}$ condenser) buried in 1968 at a depth of $1.8 \mathrm{~m}$. Area M consists of two pits comprising an 
area of about 0.08 ha and excavated to a depth of about $4.6 \mathrm{~m}$. The larger pit was used from the beginning of plant operation until 1958 to dispose of all types of trash and equipment, conti ninated and noncontaminated. The smaller pit was excovoted for disposal of all the scrop metal remaining in the yard (primarily contaminoted) which was not solable at the time this yard was cleoned up and closed. Both pits were covered with $0.5-0.9 \mathrm{~m}$ of soil. The contamination involved primarily natural or slightly depleted uranium.

The contominated scrap yard, C-746E, contains contaminated scrap metal from plant operations and comprises an areo of $0.3 \mathrm{ha}$. As of April 1977, the yard was 90 percent full.

\subsection{OPERATING PRACTICES}

Scrap uranium is generated by precipitation with lime from equipment decontamination and cylinder wash solutions. The filter sludge is collected in plastic-lined dums. When a number of drums are accumulated, personnel load them on a truck and unload them at area C-404. These drums are covered with clay soil up to within a few rows of the end of the current stack. Depleted uronium tetrafluoride is also drummed ond transported to area $\mathrm{C}-404$ for burial.

Lime sludges are conalyzed for No-237, Pu-239, Th-230, and Tc-99. Batches containing Np-237 and Pu-239 in excess of $10 \mu \mathrm{Ci} / \mathrm{kg}$ are stored retrievably in plastic-lined steel drums in warehouse C-7465. 


\subsection{PORTSMOUTH GASEOUS DFFUSION PLANT}

The Portsmouth Gaseous Diffusion Plant is located on a 16/8.8-ha reservarion in Pike County, Ohio.

\subsection{BURIAL FACILITIES ${ }^{17}$}

There are three storoge facilities at the Portsmiouth site for low-activity radioactive wastes: the $X-206-D$ storage area, the $X-744 G$ focility, and the classified waste areo.

The X-206-D storage area measures $76.2 \mathrm{~m} \times 41.5 \mathrm{~m}$, and all storage is on the ground. This area is used to store small scrap metal items which have small amkants of radicactive contamination and a high scrap resale value. The metals include copper, monel, stainless steel, nickel, bross, etc. All metal items are decontaminated prior to storoge in this area.

The $X-744 \mathrm{G}$ focility is a warehouse covering $0.8 \mathrm{ha}$. It is used primarily for storoge of $\mathrm{UF}_{6}$ contained in cylinders and for storage of nonfluorinoted materials such as $\mathrm{U}_{3} \mathrm{O}_{8}, \mathrm{UO}_{3}, \mathrm{UNH}$, uranium solutions, and radioactive plant waste. The low-activity radioactive wastes stored in this facility include the solid residues from the uranium recovery operation, contaninated alumina, magnesium fluoride, sodium fluoride, and various classified contaminated wastes and materials. Contaminated wastes are stored temporarily until a sufficient amount has been accumulated for burial. The classified waste area is capable of retrievably storing several tons of classified wostes such is barrier tube sheets, steel parts, and certoin floor sweepings. All these materials are decontaminated before storage.

The X-749 burial ground is a 2-ha site used for aboveground storage and disposal of unclassified contaminated woste. The stored materials are, for the most part, large pieces of metal $\alpha$ equipment having fixed surfoce contamination which are stored in 208-liter drums. All materiols are decontaminated prior to storage. 
Buried items in the $X-749$ trenches foll under two cotegories. Cotegory I (chernical tro waste) includes uranium-bearing solids such as olumina, sodium fluoride, magnesium fluoride, incinerator ash, and filter cake, whose uranium content is not economically recoverable. Category 2 consists of scrop metal that is potentially or slightly contaminated and cannot be sold or placed in a sonitary landfill. Scrap metal is decontaminated before burial.

\subsection{OPERATING PRACTICES ${ }^{17}$}

Before 1976, no speciol packaging procedures were used in preparing contaminated wastes for burial. Category I wastes in the X-749 trenches were buried in metal confainers. During 1976, much of the wostes were found to contain TC-99, which is water soluble. To ovoid further contamination, operating practices were changed; each packoge of chemical irop waste was sealed in plastic, and each trench was also covered with plastic. This precaution is now a standard procedure used in all burials.

Contaminated materials considered nonrecoverable are segregated and labeled for proper identification and disposal. Other contaminated wastes with no value, but with TRU concentraticn above allowable limits, are shipped to other facilities.

The individual trenches used for waste burial are excovated in the cloy soil and have surface areas ranging fram $9.3-167.2 \mathrm{~m}^{2}$. Clossified burial trenches $\sigma e$ about $4 \mathrm{~m}$ deep, and waste is covered with soil to a depth of $3.0 \mathrm{~m}$. In the unclassified burial grounds, trenches are only $2.4 \mathrm{~m}$ deep and are covered with $1.2 \mathrm{~m}$ of soil.

\subsection{WASTE GENERATION}

The accumulated volume of waste of Portsmouth is $279 \mathrm{~m}^{3}$, which contains opproximately $2700 \mathrm{~kg}$ of uranium. 


\section{FEED MATERIALS PRODUCTION CENTER (FMPC)}

\subsection{INTRODUCTION}

The Feed Materials Production Center is located near Fernald, Ohio, on o 424 tho site about $16.1 \mathrm{~km}$ northwest of Cincinnati. The primary work at FMPC is the production of purified uranium metal and compounds for use at other DOE sites. A small amount of thorium work is also done. The recyling of uronium and thorium has introduced minimal amounts of transuranic and fission products into the waste storage creas. 17

Most of the solid woste generated of FMPC results from the neutralizotion of acidic woste solutions. Filter coke and sludges collected from the neutralized wastes are deposited in chemical waste pits.

\subsection{STORAGE FACILITIES 17}

There are three long-term storoge facilities at FMPC: K-65 tanks, metal oxide tanks, and chemical waste pits. Five pits are identified by number, based on the chronological order of their construction. They are further identified as "dry" or "wet" pits, based on the physical state of the material placed in the pit.

There are two K-65 tanks and two metal oxide tanks which are each $24.4 \mathrm{~m}$ in diameter and $8.2 \mathrm{~m}$ high. The tank walls are nade out of concrete, $20.3 \mathrm{~cm}$ thick, and were post-stressed with high-tensile steel wire profected by a 1.9-cm grout coating. These were also protected by a soil embankment. The $K-65$ tanks were used for the storage of refinery residues that resulted from the processing of pitchblende ores, which was discontinued in 1959. These toiks are the property of the African Metals Corporotion and are stored at FMPC under a lease controct that expires in 1983. Only one of the two metal oxide tanks contains wastes, and both are owned by DOE. These wastes are residues resulting from the processing of ore concentrates and contain only a trace of radium. 
Pits 1, 2, and 4 are essentially inground focilities which were constructed by digging a large hole and then lining it with a $46-61 \mathrm{~cm}$ of impervious clay. Maximum depths of pits 1 and 2 are 5.2 and $4.0 \mathrm{~m}$, respectively. Both pits have been backfilled, covered with clean soil, and graded to provide surface drainage awoy from the pits. Pit 4 is partially filled and is used for the disposal of dry solids. Maximum depth of the pit is $7.3 \mathrm{~m}$. Pit 3 was constructed to receive neutralized waste slurries. The solids settled, and the supernatant flowed into on adjacent clearwell. The capacity of the pit was $174,110 \mathrm{~m}^{3}$. The pit has been filled to its capacity to function as a settling basin and partially covered with clean soil. The remaining capacity is being used for the disposol of filter cake. Once the pit has been completely filled, it will be covered, graded, and seeded to control runoff and erosion.

Pit 5 is a rubber-lined settling basin with a capacity of $87,929 \mathrm{~m}^{3}$ and a surface area of $1.5 \mathrm{ha}$. The pit is $7.6 \mathrm{~m}$ deep and is used for the disposal of neutralized liquid wastes from uranium and thorium processing.

\subsection{OPERATING PRACTICES}

There are no facilities at FMPC for the treatmenl of solid radioactive wastes. Uranium and thorium-contaminated solid wastes are disposed of in pit 4 without treatment.

Contaminoted combustible residues, sewage sludge, graphite, and oils are incinerated in various facilities. The uranium values are recovered from the generated ash.

In general, liquid wastes from uranium and thorium processing are first neutralized and then may follow one of two routes. In one route, the neutralized wastes are sent to pit 5, where the solids settle out and the supernatant overflows to a clearwell. In the other route, the neutralized wastes are filtered and the filter cake is deposited in pit 3. 
II

$\coprod$

8.4 WASTE GENERATION

As of February, 1977, opproximotely $3,135,990 \mathrm{~kg}$ of normal and enriched uranium have been ploced in pits I through 5.17

1

【

[]

II

汪

1

$\vdots$

1

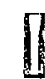

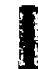

1

I

$\Gamma$

$\because$

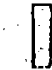




\subsection{NAGARA FALLS SITE}

\section{I INTRODUCTION}

The DOE-Niagara Falls site located in Niagara County, New York, is dorment and in caretaking status. Placement of additional radioactive wastes in storage or disposal at the site is not contemplated. ${ }^{17}$

Radioactive wastes at this site are either disposed of on the surfoce or stored in buildings. These wastes are primarily residues that were generated in the processing of pitcthblende concentrates bought from the African Metols Corporation in the Belgian Congo to obtain pure $\mathrm{U}_{3} \mathrm{O}_{8}$ during the early years of the atomic energy program.

The controct with the African Metals Corporation stipulated that, with certain specific exceptions, only the uronium content was sold to the United States, with all other minerals to remain as property of the vendor. As a result of this, about 60 percent of the wastes of this site belong to the African Metals Corporation and are stored in buildings leased from DOE until 1983. 17

\subsection{OPEN-LAND DISPOSAL FACILITIES ${ }^{17}$}

All of the radioactive wastes disposed of aboveground are the property of DOE. These wastes consist of R-10 residues, R-10 iron cake, and contaminoted soil removed from surrounding areas in a decontamination operation that took place in 1972.

The $\mathrm{R}-10$ residues were generated from a 3 percent $\mathrm{U}_{3} \mathrm{O}_{8}$ pitchblende, which was given a cyanide treatment for removal of precious metals. These residues amount to $7.5 \times 10^{6} \mathrm{~kg}$, containing 0.1 pecent $\mathrm{U}_{3} \mathrm{O}_{8}$ and having a radioactivity of $3.75 \mathrm{mR} / \mathrm{hr}$ at the surface. To eliminate a potential dust hazard, $R-10$ residues were covered with topsoil and grass-seeded in 1964. The R-10 iron cake is a byproduct residue from 3 percent $\mathrm{U}_{3} \mathrm{O}_{8}$ pitchblende and contains no radium. The material is primarily lead vanadate. A total of $1.4 \times 10^{5} \mathrm{~kg}$ containing 0.4 
percent $\mathrm{U}_{3} \mathrm{O}_{8}$ and having a radioactivity of $2.24 \mathrm{mR} / \mathrm{hr}$ at the surface wos disposed of adjocent to the $R-10$ residues.

The $11,469 \mathrm{~m}^{3}$ of soil and buried debris removed in a decontaminction operation in 1972 was piled up to o height of $4.5 \mathrm{~m}$, occupying an area of 0.4 ha. A radiation survey indicated a moximum reading of $3.5 \mathrm{mR} / \mathrm{hr}$ of $0.9 \mathrm{~m}$ above the surface of the pile. Soil samples indicated contaminotion due to uranium and/or radium.

\section{OTHER FACILITIES}

Of the radioactive waste stored inside buildings, only the F-32 and Middlesex Sond wastes are owned by DOE. Both wastes are stored in the same buiiding. There are $1.3 \times 10^{5} \mathrm{~kg}$ of $\mathrm{F}-32$ and $1815 \mathrm{~kg}$ of sands in storage containing I percent and 4 percent of $\mathrm{U}_{3} \mathrm{O}_{\mathrm{g}}$, respectively.

The radioactive wastes owned by the African Metals Corporation and stored at DOE-Niogara Falls consist of $1.6 \times 10^{6} \mathrm{~kg}$ of K-65 residues, $7.5 \times 10^{6} \mathrm{~kg}$ of L-30 filter cake, and $1.7 \times 10^{6} \mathrm{~kg}$ of L-50 sludges. $K-65$ residues are stored in a 50.3$m$-high reinforced concrete tower. These residues contain 0.3 percent $\mathrm{U}_{3} \mathrm{O}_{8}$ and have o radioactivity of $5 \mathrm{mR} / \mathrm{hr}$ of $1.8 \mathrm{~m}$ above the surface. The $L-30$ filter cake contains 0.2 percent $\mathrm{U}_{3} \mathrm{O}_{8}$ and has a radioactivity of $13 \mathrm{mR} / \mathrm{hr}$ at the surface. The L-50 sludge originated from a 6 percent $\mathrm{U}_{3} \mathrm{O}_{8}$ pitchblende processed in 1944. This sludge contains 0.1 percent $\mathrm{U}_{3} \mathrm{O}_{8}$ and a radioactivity of $8 \mathrm{mR} / \mathrm{hr}$. 


\subsection{WELON SPRING SITE}

\subsection{INTRODUCTION}

The Weldon Spring operation, located in St. Charles County, Missouri, has two separate disposal sites approximately $6.4 \mathrm{~km}$ opart: the raffinate pits area and the quarry. Since no radioactive wastes are generated at the present time at Weldon Spring, octivities at these sites are limited to the caretaking and monagement of woste burial fncilities.

\subsection{DISPOSAL FACILITIES ${ }^{17}$}

The two disposal sites mentioned above comprise a total areo of $24.7 \mathrm{ha}$.

The raffinate pits consists of four pits having a total capacity of approximately $492,700 \mathrm{~m}^{3}$. The radioactive wastes disposed of in these pits are primarily raffinates from the refinery operation and magnesium fluoride slurry from the uranium recovery processes performed by the Weldon Spring Production Center.

Approximately 70 percent of the residues disposed of in pits 1, 2, and 3 are neutralized raffinates from refinery operations. The wastes were pumped as slurry into the pits, the solids settled out and remained, and the supernatant overflowed into the plont sewer. The remaining 30 percent of the residves are washed slog residues from the uranium metal production operation. In oddition to some uranium residues similar to those in pits 1-3, pit 4 contains roffinate solids from the processing of thorium recycle materials in the refinery.

A total waste volume of $168,102 \mathrm{~m}^{3}$ hos been disposed of in these pits. It is estimated that $75,802 \mathrm{~m}^{3}$ of free water is retained atop the sludges in the residue pits.

The quarry site consists of an open pit primarily used for disposal of chemical and radioactive contaminated waste. Prior to its acquisition by the Atomic Energy Commission, the Department of the Army used the quarry for the 
disposal of TNT-contaminated scrop metal. No dato are ovailable cbout how much of this material was disposed of in the quarry. The Atomic Energy Commission first used the quarry in 1959 for the disposal of drummed residues containing approximately 3.8 percent thorium.

In 1963-1964, opproximately $38,211 \mathrm{~m}^{3}$ of uranium- and radium-contaminated scrop metal was disposed of in the quarry. This material consisted of contaminated process equipment, building scrap, and soil. Additional drummed thorium residues containing 3.8 percent thorium- and TNT-contaminated wastes were disposed of in the quarry during 1966. During 1967-1968, on estimated volume ranging from 3818 to $7636 \mathrm{~m}^{3}$ of contaminated equipment and scrap metal was disposed of in the quarry by the Army in its decontamination operations of the Weldon Spring Plant. 


\section{IID PANTEX PLANT}

\section{II.I INTRODUCTION}

The 1.4-ha burial site is centrally locofed on the Llano Estacado within ithe 3683ho Pontex Plont, which is located $29 \mathrm{~km}$ northeast of Amarillo, Texas. All radioactive waste buried at this site is considered retrievable over a period of 20 years.

\subsection{BURIAL FACILITIES ${ }^{17}$}

Rodioactive waste is pockaged for burial in the generating area in plastic bags and overpacked in 18.9-liter cans or in fiberglassed wood boxes.

Waste is stored in vertical concrete cylinders $(6.1 \mathrm{~m}$ deep $\times 1.8 \mathrm{~m}$ in diameter) or in trenches ( $30.5 \mathrm{~m}$ long $\times 4.3 \mathrm{~m}$ wide $\times 4.0 \mathrm{~m}$ deep). Once filled with waste, the cylinders are capped with a concrete plug and covered with $1.8 \mathrm{~m}$ of compacted soil. Waste stored in trenches is also covered with $1.8 \mathrm{~m}$ of compocted soil.

\subsection{WASTE GENERATION ${ }^{17}$}

No TRU wastes are routinely generated at Pantex, and the small amount of TRU waste from nonroutine sources is segregated from the other wastes and buried in a separate trench in fiberglassed boxes. The current annual rate of waste burial is $1.4 \mathrm{~m}^{3} /$ year, which contains $134 \mathrm{~kg}$ of uranium, which is the primary component of the wastes. 


\subsection{SANDIA LABORATORIES (SL)}

\subsection{INTRODUCTION}

Sondia Labnratories is lacated at the foothilis of the Manzano Mountains near Albuquerque, New Mexico. The current 0.6-ha radioactive disposal site is located in an environmental test area, Tech Area III, of Sandia Laboratories. An old burial ground (closed in 1960), consisting of an area of 0.11 ha, is locoted in an explosive test orea, Tech Areo II.

\subsection{BURIAL FACILITIES ${ }^{17}$}

The active disposal site is divided into three areas: one for the disposal of classified nuclear weopon components, onother for the disposal of bulky debris, and the last for future expansion. Open trenches and burial shafts are the two methods of disposal employed at SL.

The form of the waste determines the pockoging used for burial. All liquids are solidified and packaged. All decontamination woste is sealed inside plastic bags. For large equipment, removable contamination is either fixed or contained. Radioactive components are bagged. An instrument survey is performed at this time to determine if radiation levels or removable contamination precludes normal handling.

Open trenches ( $55 \mathrm{~m}$ in length $\times 11 \mathrm{~m}$ in width $\times 4 \mathrm{~m}$ in diameter) are used for very low activity or suspect radioactive waste. This includes decontamination debris, HEPA filters, surplus contaminated equipment, experimental structures used in contaminated areas, solidified liquids, etc,

Open trenches are periodically bockfilled to prevent any possible escape of loose contamination and to reduce fire hazard.

Burial shafts ( $3 \mathrm{~m}$ in length $\times 3 \mathrm{~m}$ in width $\times 8 \mathrm{~m}$ in diameter) are used to dispose of all radioactive devices with security classification, radioactive sources 
than $10_{\mu} \mathrm{Ci}_{\text {, and }}$ uranium machining waste, as well as any other uranium waste that is a potential fire hazard.

Each active shoft is covered by a steel platform containing a locked door. The shafts are used until the level of waste is within $2 \mathrm{~m}$ of the surface, at which time they are backfilled and the soil is allowed to settle. After approximately 1 year of settling, the shofts are capped with concrete.

Before retrievable storage of TRU waste became a DOE requirement, plutoniumcontaminated debris from nuclear weapons tests was placed in one trench in the disposal area. This waste is not considered retrievable. Subsequent TRU waste generated at SL and requiring retrievable storagu? has been transported to $\mathrm{on}$ offsite DOE storage facility. Currently (1977), no iRU wastes are being generated at $\mathrm{SL}$.

\subsection{WASTE GENERATION ${ }^{17}$}

The current cumulative inventory indicates that a total volume of $1322 \mathrm{~m}^{3}$ of radioactive waste has been disposed of at this site since operations started. This total includes primarily fission product/induced-activation products, $152.8 \mathrm{~m}^{3}$ of uranium-contaminated wastes, $15.7 \mathrm{~m}^{3}$ of TRU-contaminated wastes containing less than $10 \mathrm{nCi} / \mathrm{g}$, and $0.2 \mathrm{~m}^{3}$ of TRU-contaminated wastes containing more than $10 \mathrm{nCi} / \mathrm{g}$ (which were buried prior to the retrievable stcroge requirement). The cumulative decayed activity is $2.4 \mathrm{KCi}$. 


\section{NEVADA TEST SITE (NTS)}

\subsection{INTRODUCTION}

T.e Nevado Test Site is locoted in Nye County, Nevada, and comprises an area of $371,158 \mathrm{ha}$. Of this area, 155,404 ho are used for nuclear testing programs and the remaining areo provides a variety of possible radioactive waste management locations. A.t present, less than 81 ha are being used for woste management operations at NTS. Seven sites are used at NTS for the storoge and disposal of radioactive waste: area 5 RWMS, R-MAD RWMS, U3ox crater, U3fi drillhole, Horn Silver mineshaft, U2bu croter, and UBd postshot drillhole.

\subsection{STORAGE FACILITIES ${ }^{17}$}

Area 5 RWMS is used for both storage and disposal of radioactive waste and comprises on area of 15.7 ha. Pads are used for the storage of tritiumcontaminated waste, low-activity TRU waste, and potentially reusable activated or contaminated hardware and equipment.

The R-MAD (reactor-maintenance, assembly, and disassembly) facility is used for the storage of recctor hardware remaining after the preparation of expended fuel elements and covers $\boldsymbol{m}$ areo of $\mathbf{2 2 . 3}$ ho. This site wos used in the past for both disposal and surface starage of radioactive hardware and waste from the nuclear rocket development program.

Twenty-six additional rodiactive waste sites are used for surface storage at NTS. These are considered retired or inactive because no wastes are being added to the sites. Most of the waste stored at these sites consists of contaminated parts from a large exhaust deflector, reactor cores, and nuclear test wastes. Current plans ore to remove the waste stored at these sites and consolidate it in a disposal site. 


\subsection{DISPOSAL FACILITIES ${ }^{17}$}

Area 5 RWMS is used for the disposal of classified wastes. The wastes are disposed of in trenches having a with and depth of coout $3.2 \mathrm{~m}$ and a length of 90-180 $\mathrm{m}$. Excovations are filled with radioactive waste to near surface level. Then a final soil cover at least 0.9-m thick is placed on top of the waste. TRU waste is restricted to area 5 RWMS, where it is stored on the surface in closely spaced, sealed drums. However, a storage pad is being constructed in FY-1978.

The U3ax croter is a croter from a past underground nuclear test which originally was $129.5 \mathrm{~m}$ in diameter and $18.3 \mathrm{~m}$ deep. The crater is now used for the disposal of large unpackoged waste items. There are $46,000 \mathrm{~m}^{3}$ of burial capacity still ovailable (1977) for disposal of this site. Lond burial at the U3ax crater consists of cut-and-fill operations. Loyers of low-activity contaminated waste ore covered with loyers of soil from the crater sides.

The U3fi drillhole, originally intended for emplacement of a nuclear test device, is chout $1.8 \mathrm{~m}$ in diameter and was plugged with concrete at a depth of about $240 \mathrm{~m}$ before abandonment. Now the hole is used for disposal of classified waste consisting of drilling core amiples containing radioactive debris from weapon tests.

The Hom Silver mineshaft is an abondoned mineshaft used for the disposal of classified radioactive waste. Most of the waste already deposited there was generated during Project Pluto, a past nuclear ramjet engine test series. A concrete plug has been poured over the wastes at a depth of about $128 \mathrm{~m}$, and o concrete collar pad with a steel cover and lid has been installed on the shaft. The remaining unused volume is about $700 \mathrm{~m}^{3}$.

The U2bu crater was used for disposal of low-activity contaminated dilling mud and liquid. The crater was originally about $230 \mathrm{~m}$ in diameter and $31 \mathrm{~m}$ deep, but now is nearly full of drilling mud. The U8d postshot drillhole is used for the disposal of low-activity contaminated liquid waste. This is accomplished by attaching the dain hose of the tanker transporting the wastes to a valve 
connector and hose permanently installed in a flange over the U8d casing. There ore 10 seepage basins at NTS which were used for the collection of low-activity contaminated water and other liquids generated by mining and decontamination operations.

\subsection{WASTE GENERATION}

The totol accumulated amount of waste is $5.07 \mathrm{KCi}$ and the current disposal rate is $125 \mathrm{~m}^{3}$ /year. The total volume of TRU waste stored is $90 \mathrm{~m}^{3}$, which contains $1.3 \mathrm{~kg}$ of transuranics. 


\subsection{ARGONE NATIONAL LABORATORY (ANL)}

The Argonne National Laboratory (ANL) is located in Argonne, Illinois, and is operated by the University of Chicago for DOE.

\subsection{BURIAL FACILITIES'}

There is no active burial ground at ANL; however, during the decommissioning of the original laboratory (in Chicago proper) building rubble was buried in the Cook County Forest Preserve. Other ANL-generated waste and building rubble were also buried at this surveillance site.

\subsection{WASTE GENERATION}

ANL. produces o wide variety of solid radioactive waste suitable for land burial. About $40 \mathrm{~m}^{3}$ per year of solid waste results from liquid radwaste treatment. The solid waste produced annually is about $845 \mathrm{~m}^{3}$. In the pasi $-1 /$ waste was shipped to Sheffield, Illinois, for buriol. Present shipping activities are unknown.

ANL also operotes one facility at INEL where on-site burial is practiced. 


\subsection{OTHER DOE SITES}

\subsection{WASTE QUANTITIES AND PRESENT DISPOSAL METHODS ${ }^{18}$}

The quantity of solid waste contaminated with transuranics expected to be generated mnually at other DOE sites varies from about one cubic meter at Sandia Laboratory, to about $230 \mathrm{~m}^{3}$ for Argonne National Laboratory (Table E15). Sites in fovorable geographic locations (remote, dy, etc.) bury solid waste on site while those in less fovorable locations ship to commercial burial grounds. Based on the experience of the larger national laboratories and production sites, about 10 percent of the total solid waste generated annually by these sites is expected to be non-LSA waste. About 60 percent of this would be expected to be shipped to a TRU waste repository in steel drums and about 40 percent in steel boxes or bins. 
TABLE E-15

QUANTITIES OF SOLID WASTE CONTAMINATED WITH TRANSURANICS EXPECTED TO BE GENERATED AT OTHER DOE SITES ${ }^{18}$

\begin{tabular}{|c|c|c|c|c|c|}
\hline Site & $\begin{array}{l}\text { Volume } \\
\left(\mathrm{m}^{3} / \mathrm{rr}\right)\end{array}$ & $\begin{array}{l}\text { Burial } \\
\text { (for transport } \\
\text { and burial) }\end{array}$ & Containers & $\begin{array}{l}\text { nbusiible } \\
\text { lume \%) }\end{array}$ & $\begin{array}{l}\text { Alpha Activity (a) } \\
\text { (as shown) }^{(b)}\end{array}$ \\
\hline Sandia Laboratory & 1.1 & on-site & $\begin{array}{l}0.06 \mathrm{~m}^{3} \text { plastic bags and } \\
0.6 \text { to } 0.9 \mathrm{~m} \text { cardboard boxes }\end{array}$ & 100 & $\begin{array}{l}\text { range: } 0.01 \text { to } 0.1 \mathrm{Ci} \\
\text { avg.: } 0.01 \mathrm{Ci}\end{array}$ \\
\hline Brockhaven National Laboratory & 5.7 & off-site & $\begin{array}{l}1.2 \mathrm{~m} \times 1.8 \mathrm{~m} \times 2.4 \mathrm{~m} \text { steel } \\
\text { bins }\end{array}$ & 90 & $\begin{array}{l}\text { range: } I_{10} \mathrm{CI}_{\mu \mathrm{Ci}}^{\text {to }} \text { im } \mathrm{Ci} \\
\text { ovg-: }\end{array}$ \\
\hline Battelle Mamorial Institute & 15.9 & off-site & 208-liter steel drums & 75 & $\begin{array}{l}\text { range: unknown } \\
\text { ovg-: unknown }\end{array}$ \\
\hline $\begin{array}{l}\text { Lawrence Radiation Laboratory } \\
\text { (Berkeley) }\end{array}$ & 32.4 & off-site & 114- and 208-liter steel drums & 90 & $\begin{array}{l}\text { range: } I_{100} \mathrm{Ci}_{\mu} \text { to } \mathrm{Ci} \mathrm{Ci} \\
\text { avg e: }\end{array}$ \\
\hline Lawrence I_ivermore Laboratory & 132.5 & off-site & 208-liter steel drums & 75 & $\begin{array}{l}\text { range; } 1 \text { to } 10 \mathrm{Ci} \\
\text { avg.: } 0.25 \mathrm{Ci}\end{array}$ \\
\hline
\end{tabular}

a. Alpha octivity includes Pu-238, Pu-239, Am-241 and/or Cm-244.

b. Activity content of packages; not of a unit volume or weight. 
II

II

4

15

1

1

1

1

II

APPENDIXF

COMMERCIAL BURIAL SITES 


\section{I.D NTRODUCTION}

The term "burial," as used in this report, refers to the placement of waste at relatively shallow depths in earth materials, with ro intent or provision for ready retrievability at a later date. Buried wastes are subject, in some degree, to the influence of water, infiltration and movement, erosion, plant uptake, onimal penetration, and human activity. ${ }^{2}$ The consequent migration or dispersal of radioactive and other toxic materials must be kept to some minimum or acceptable level. The physical and chemical form of the waste, engineered containment mechanisms, and the surrounding earth materials can be used to attain the desired level of containment.

Shallow earth burial has been used for the disposal of radioactive waste since the inception of nuclear weopons research in the 1940's. Initially, only the Atomic Energy Commission's national laboratories and contractor facilities handled and disposed of radioactive waste. Burial grounds were operated of each facility for the disposal of waste generated by weapans development and other nuclear research programs. Radioactive wastes geneiated by private industry were initially disposed of at the AEC-operated burial grounds.

The volume of radioactive wastes generated by private industry increased dramatically during the 1950's. Burial grounds operated by the AEC at Oak Ridge National Laboratory (ORNL) and at the National Reactor Testing Station (NRTS) in Idaho received some of this waste. However, the majority of the radioactive waste generated by private industry was managed by sea disposal services offered by private companies.

Growing pressures against sea disposal led to the AEC in January 1960 designating regional land disposal sites which would accept waste for burial from private industry and from AEC contractors without burial facilities. ${ }^{3}$ Under this interim policy (May 1960), suitably packoged wastes were accepted for burial at ORNL and NRTS until such time as commercial burial sites became ovailable. In February 1961, the AEC established regulations to permit commercial operation of low-level burial grounds on Federal or state owned land. 
In September 1962, a commercial burial facility was opened in Beatty, Nevada. This burial ground, licensed by the regulatory branch of the AEC, provided an alternative to both seo disposal and the AEC facilities. A similar site was opened shortly thereofter in Morehead, Kentucky, and in 1963, the AEC discontinued its policy of accepting radiooctive waste from private industry. In the following years additional commercial sites were opened in other states and by 1971 six commercial buriol grounds were licensed for the handling and disposal of radioactive waste (see Figure F-1). The last disposol of radioactive woste ot seo was conducted in June 1970.

Wastes presently huried at both commercial and Department of Energy (DOE) facilities contain a large variety of radioactive materials, ranging from low activity radiopharninceuticals to high actiyity fission products and trace quantities of tronsuranic isotopes. The hazards these wastes pose to man and his environment are primarily dependent on their radioactive properties, rather than on their chemical toxicity. The time frame of the hazard is dependent on the half-life of the specific radionuclide. The bulk of the radionctive materials at existing sites exhibit half-lives on the order of tens of years or less, and at typical concentrations will thus decay to innocuous levels in periods of less than a few hundred years. In the human time frame, the hazard period of other materials, such as Pu-239 with a 24,000-year half-life, differs little from that of toxic stcble elements like chromium.

In 1970, the AEC implemented policies limiting the burial of long-lived transuranic radionuclides at AEC operated sites. Such waste containing greater than 10 nanocuries per gram were sent to retrievable starage facilities. The AEC issued a proposed rule on September 12, 1974 which would have limited burial of transuranic wastes at commercial sites also. Following creation of the NRC and ERDA, ERDA withdrew the draft environmental statement needed to fulfill NEPA requirements for the rule. Although the rule has not been implemented, all the commercial burial sites except the Richland site presently limit the burial of transuranium nuclides. 3 


HANFORD, WA

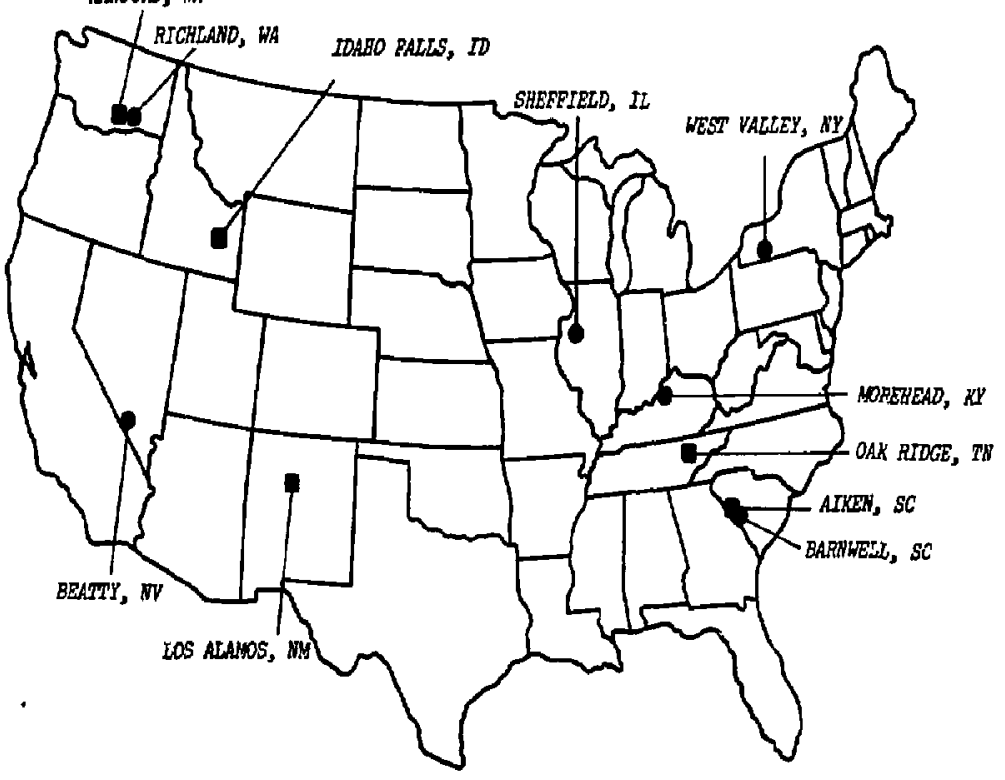

- whOR dOE SITES

- conercial sites

FIGURE F-I

BURIAL SITE LOCATIONS

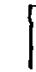




\subsection{BURIAL SITE DESIGNOBJECTIVES}

The containment capability of a burial ground is dependent on the physical and chemical form of the emplaced waste, the retaining ability of the natural system surrounding the waste, and any engineering modifications to the system. In general, migration of radionuclides from buried waste to mon's environment involves two separate phenomena: dissolution of radionuclides in the waste by water in contact with it, and movement of the liquid containing the radionuclides away from the burial emplacement at a sufficient velocity that they enter man's environment during their hazordous lifetime. Most physical and biological processes that mobilize and transport radionuclides can be described in these general terms. Thus, measures that impeded either of these phenomena will increase the containment ability of a burial site.

Commercial burial grounds have been located on the basis of regional requirements for waste disposal facilities. Site selection involved the survey of several prospective sites, with the final decision based on hydrogeologic and economic factors.

The single most important factor affecting thin containment copobility of a burial ground is the degree to which ground and surfoce water can contact the waste and subsequently couse migration of the radionuclides. As a result, a hydrologic assessment is required as a portion of the licensing procedure for each site. In effect, these studies provide an estimate, prior to use of the burial ground, of the degree to which ground and surface woter will contact the waste following burial, the pathway of the water awoy from the burial site, the ion-exchange or adsorptive capability of the materials along that path, and the extent to which the radionuclide content of off-site ground and surface waters will be effected by the burial grounds.

The important characteristics related to the containment copability of each of the six commercial sites are presented in Table F-I. Earth materials tend to be both non-homogeneous and anisotropic. Solid waste burials are universally 

locoted at shallow depths; in the transition zone between soil materials and subsurface geology. The numerical volues provided in Table F-I are either estimates of a range of values, or approximate mid-range values. Some values vary from point to point and on a seasonal ard annual basis of each burial site. 


\subsection{CURRENT PRACTICES AND EXPERIENCE}

The purpose of this section is to describe existing commercial (and DOEoperated) radioactive waste burial facilities and technology.

\subsection{COMMERCIAL TECHNOLOGY}

Three companies operate the six commercial burial facilities (see Figure F-I): Chem-Nuclear Systems, Inc., (CNS) operates a site at Barnwell, South Carolina; Nuclear Fuel Services (NFS) operates a site at West Valley, New York; and Nuclear Engineering Company (NECO) operates the sifes at Sheffield, Illinois; Beatty, Nevada; Richland, Washington; and Morehead, Kentucky (also referred to os the Maxey Flats facility).

There is considerable similarity in the overall operations of the six commercial woste disposal sites. Small differences are found in wastes accepted, surface water control provisions, and other site-specific regulations.

\subsection{WASTES ACCEPTED FOR BURIAL}

Wastes buried at the commercial facilities originate not only from the nuclear fuel cycle, but also from sources such as educational institutions, hospitals, government installations, industrial research and production facilities, pharmaceutical manufacturers, and waste disposal and decontamination companies. Table F-2 shows the historical use of the West Valley site. Waste commonly referred to as low-level is characterized as mostly paper trash with vorying other items such as packing materials, protective clothing, broken glassware, plastic sheeting and tubing, radioactive carcasses of experimental animals, obsolete contaminated equipment, and building rubble. Higher activity wastes typically originate from the nuclear fuel cycle. Common wastes in this category include spent ion exchange resins, filters, filter sludges, evcporator bottoms, shielding, piping, instrumentation, control rods, and equipment and materials with induced radiooctivity. Radioactive wastes not accepted for burial generally include 
TABLE F-2

HISTORICAL USE OF THE WEST VALLEY COMMERCIAL BURIAL SITE ${ }^{4}$

Type of Facility

Nuclear power plants

Institutional, educational, and hospitals

Federal government

Industrial and pharmaceutical manufacturing and research and development

Waste disposal and decontamination companies

Nuclear Fuel Services, Inc.
Waste

volume

(\%)

22.6

1.8

12.0

4

$$
12.0
$$

70

38

21.5

19.2

$\begin{array}{ccc}9 & 5 & 19.2 \\ \frac{1}{125} & \frac{1}{72} & \frac{23.0}{100.0}\end{array}$


materials whose inherent chemical toxic or hazardous properties are judged to be greater than their radioactive hazard. Materials that have pyrophoric or explosive characteristics, free liquids, and compressed gases above one atmosphere are excluded from burial at all sites. Some sites accept liquids, but effect solidification prior to burial.

Limitotions on package external radiation and radionuclide content also exist, but specific values vary. ${ }^{8}$ Generally, limitations on the quontities of radioactive materials that can be stored above ground prior to burial are opplied to three categories of waste. By-product material includes "any radioactive materials (except special nuclear materials) yielded in or made radioactive by exposure to the radiation incident to the process of producing or utilizing special nuclear material. ${ }^{5}$ Special Nuclear Materials (SNM) refer to fissile radionuclides such as U-235, U-233, or Pu-239. Source materials are those which can be converted in a reactor to SNM, and include materials such as natural uranium and thorium. State-regulated site-specific restrictions for the on-site possession (unburied) of these are given in Toble F-3. Wastes with transuranic alpha-emitting contamination above $10 \mathrm{nCi} / \mathrm{g}$ are only accepted for burial of the Richland site, Specific restrictions on acceptable wastes appear to be the most restrictive at the West Valley, New York site (no longer in operation). In addition to those materials already listed, other excluded materials include infectious materiols, poisons, insecticides, rodenticides, herbicides, fungicides, and other such materials.

\subsection{WASTE PACKAGING}

No Federal or state standards hove been developed for the burial of radioactive waste. In lieu of such standards, waste packogings are determined primarily by Departrnent of Transportation (DOT) regulations for the shipment of radioactive materiols. Most waste packaging methods presently in use are not intended to provide containment following burial since the soil is considered to be the primory container. 
TABLE F - 3

BURIAL. SITE CRITERIA AND RESTRICTIONS

\begin{tabular}{|c|c|c|c|c|c|}
\hline West Volley & Maxey flats & Barnwell & Sheffietd & Prichtond & Beolty \\
\hline SOLLED & SOLIID & SOLID & SOLU1D & SOLID & \\
\hline \multirow[t]{2}{*}{ Must be pockoged. } & $\begin{array}{l}\text { Must be packoged, except } \\
\text { thof dojects with induced } \\
\text { rodiooctivity ond no re- } \\
\text { movoble contornination ore } \\
\text { exempt from pockoging. }\end{array}$ & $\begin{array}{l}\text { Must be packoged, except } \\
\text { that objects with incheed } \\
\text { rodiooctivily ond mo re- } \\
\text { movable contamination are } \\
\text { exempt from pockoging. }\end{array}$ & Mus! be packoged. & Must be pockoged. & $\begin{array}{l}\text { Must be pockaged except } \\
\text { that solida with induced } \\
\text { radiooctivily and no } \\
\text { remoweste comlomino- } \\
\text { tion are exempl from } \\
\text { pockoging. }\end{array}$ \\
\hline & $\begin{array}{l}\text { Dowatered resins in strong, } \\
\text { tight containers ond do-. } \\
\text { watered are occeptable. }\end{array}$ & $\begin{array}{l}\text { Dewotered resins ore } \\
\text { occeptobte. }\end{array}$ & $\begin{array}{l}\text { Resins solidified with } \\
\text { chemicals or cement oro } \\
\text { occeptoble. }\end{array}$ & $\begin{array}{l}\text { Dewatered resins ore } \\
\text { occeptoble. }\end{array}$ & $\begin{array}{l}\text { Dewatered resins ore } \\
\text { aeceptoble. }\end{array}$ \\
\hline 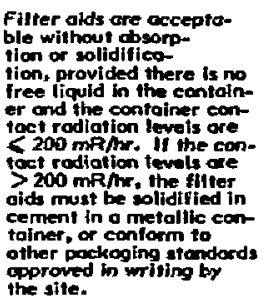 & $\begin{array}{l}\text { Filfer aids must be soli- } \\
\text { dified. }\end{array}$ & $\begin{array}{l}\text { Fllter aids must be solj- } \\
\text { dified. }\end{array}$ & $\begin{array}{l}\text { Fulter oids must be soli- } \\
\text { dified. }\end{array}$ & $\begin{array}{l}\text { Filfer aids must be soli- } \\
\text { dified. }\end{array}$ & $\begin{array}{l}\text { Filfer aids must be soli- } \\
\text { dified. }\end{array}$ \\
\hline 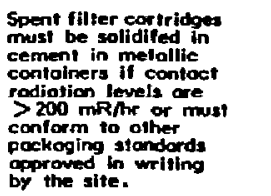 & $\begin{array}{l}\text { Spent filler cartridges } \\
\text { in a disposoble cantoiner } \\
\text { are acceptoble withoul } \\
\text { solidifieotion. }\end{array}$ & $\begin{array}{l}\text { Spent filter cortridges } \\
\text { in a disponable contoiner } \\
\text { are acceploble withouit } \\
\text { solidificalion. }\end{array}$ & $\begin{array}{l}\text { Spent filier cortridges } \\
\text { in a disposoble contriner } \\
\text { are cceppoble without } \\
\text { solidification. }\end{array}$ & $\begin{array}{l}\text { Spent filter cortridges } \\
\text { in E disposoble container } \\
\text { ire deceptoble without } \\
\text { solidificalion. }\end{array}$ & $\begin{array}{l}\text { Spent filter cortridges } \\
\text { in a dispossble contoiner } \\
\text { are occeptlble without } \\
\text { solidificalion. }\end{array}$ \\
\hline \multicolumn{6}{|l|}{$\begin{array}{l}\text { > greater then } \\
\text { \& less thon or equal to } \\
\text { \& not greater thon }\end{array}$} \\
\hline · & & & & & \\
\hline
\end{tabular}




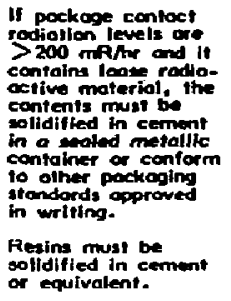

POSSESSION LIMITS Non-TRU byproduct

Specinal nucleor

U-235: 350 grams
U-233: 200 groms

For Pu-239, site irnImposes a I grom

$>$ greater then less theri or equol to
not greater than
POSSESSLON LIMITS

Non-TRU Gyproduct Roolerilol (excopt
Ra-226): 150000 curles
Ra-226) 500 millicuries

Source moles ials

spoeilial nucleor

U-235: 350 groms

20 grouns/pockoge
POSSESSION LIMITS Non-TRU byproduct

\section{Source moteriol:
$27,273 \mathrm{~kg}$}

Special nucleor

U-235: 350 groms
POSSESSIONNLIMITS Non-TRU byproduct.

\section{Source materials
$18,182 \mathrm{~kg}$} specciol nucleor moterlol: (U) 235: 500 groms (5)233: 300 groms (1) Pus g/roockoge) D20 grans/pncfage
530 grams/m/pockose
in combination.
POSSESSION LLMITS Non-TRU byproduct

Source moteriahs Spocial nucloor

$4-235 t 350$ grams

(P100 g/pockoge)

(1)60 g/pockoge)

Pus: 200 groms D 530 grams/ $/ \mathrm{m}^{3} /$ pacrikge
POSSESSION LIMITS

Nan-TRU byproduct

\section{Source moterial:} Special nucleor U-235: 500 orains it233: 300 groms Pus: 300 groms

P 530 grams $/ \mathrm{m}^{3} /$ pockoge 
Weat Volley

Tronsurantc maler lalss Sine imposes limit thot phutonium in wasto hall not excoud o. grom/pock ogo or $\mathrm{j}^{\mathrm{j}}$ of

$\frac{T}{N}$ waste.

MISCELLANEOUS No explositac or pyrto-
phortic moteriols in packopes.

Noo rree woler in

Shlpments must be

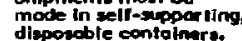

Toxic wantel ore not

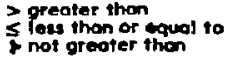

\section{TABLE F-3}

\section{(CONT.)}

Maxer Flots
10 nonocurles/grom

MISCELLANEOUS Rodiootive wastes with toxic wass les mor noi be

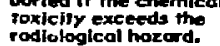

Bornwell

Tronsuranie materialss Except for Am-241, ore oceepted at this silt wilth the limit of

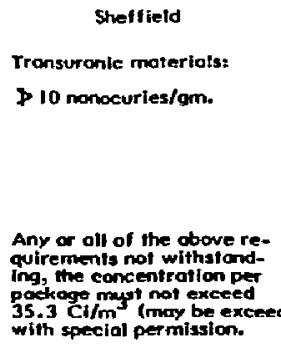

Sheffield

Tronsuromic materiots:

$\$ 10$ nonocuries/gm.

Any or oll of the obove re-

ing, the concentration per

pachogo must mot execed

$35.3 \mathrm{Cd} / \mathrm{m}$ (may be exc
with special permisston.

Tronsuranic moterials;

At present no

specific limil is oddod
io the spectal nueleor
molerial fimitations.

Pio nonocuries/oram.

MISCELLANEOUS

Rodiocictive wastes with toxic wastes may not b
burried if the chemical toxicity oxceeds the

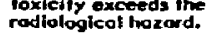

MISCELLANEOUS Rodilooctive waspes with Toxic wastes ore not
ossociofed chemically
occepted toxlc wastes moy not bo burled if the chemicas loxlcicly exceeds the
radiological trozord.
MISCELLANEOUS

Currently. comblinations of costes we inot cocepted for
Transuranic moterials:

$\$ 10$ nanocurles/oram. 
The bulk of the waste materials are packaged in 208-liter DOT-approved mildsteel drums. ${ }^{4}$ Very low-level wastes (generally microcurie quantities) may be shipped and buried in wood or fiberboord boxes. Current practice at all sites is to bury waste materials in the same contoiners in which they are received with the exception of moterial which requires transportation in on expensive reusoble shielded cask. This waste is packaged in a contoiner or liner which can be safely removed from the cask and placed in a trench.

\subsection{BURIAL PROCEDURES}

Open trenches are used at all sites as the primary burial facility. ${ }^{7}$ Trench design is similar at all facilities, ranging in physical dimensions, from 60 to $260 \mathrm{~m}$ long, eight to $20 \mathrm{~m}$ wide of ground surface, and five to eight $m$ deep. For all the burial sites it has been specified that the bottom of the trench shall be above the moximum ground woter elevation.

Techniques to cover and seal woste in trenches vary with the locol climate, soil, and ground water conditions. One to three meters of soil is mounded and graded over the top of the waste, the mound being one to two meters high over the centerline of the trench, at the more orid western sites no special attempts are made to further compoct the fill or seal the trenches. Efforts at the other four sites involve more impermeoble soils such as clay in constructing the cover, reseeding the mound, and construction of drainage fields around the mounded trenches.

\subsection{BURIAL SITE INVENTORY}

Existing buried woste inventories at the six sites, through 1977, are given in Tables F-I through F.7. All of this material is low-level solid waste in the sense that it has not originated from the first stage of a nuclear fuel reprocessing operation. 
TABLE F-4

COMMERCIAL SITES LOW-LEVEL WASTE BURYSL HISTOFY 3 , 9-14

\begin{tabular}{|c|c|c|c|c|c|c|c|c|c|c|c|c|c|c|c|c|c|}
\hline \multirow[b]{2}{*}{ YEAR } & \multirow[b]{2}{*}{1962} & \multirow[b]{2}{*}{1963} & \multirow[b]{2}{*}{1964} & \multirow[b]{2}{*}{1965} & \multirow[b]{2}{*}{1966} & \multirow[b]{2}{*}{1967} & \multicolumn{4}{|c|}{ NASTE VOLUME BURIED $\left(\mathrm{m}^{\circ}\right)$} & \multirow[b]{2}{*}{1972} & \multirow[b]{2}{*}{1973} & \multirow[b]{2}{*}{1974} & \multirow[b]{2}{*}{1975} & \multirow[b]{2}{*}{1976} & \multirow[b]{2}{*}{ 1977* } & \multirow[b]{2}{*}{ TOTAL } \\
\hline & & & & & & & 1968 & 1969 & 1970 & 1971 & & & & & & & \\
\hline Bealiy & 1,860 & 3,510 & 2,840 & i,989 & 3,530 & 3,210 & 3,580 & 4,280 & 4,130 & 3,590 & 4,300 & 4,090 & 4,100 & 4,173 & 3,864 & 5,012 & 58,054 \\
\hline Morethead & & 2,210 & 3,870 & 5,750 & 5,560 & 7,820 & 0,180 & 10,400 & 12,500 & 13,200 & 15,600 & 10,100 & 8,520 & 17,098 & 13,783 & 425 & 135,016 \\
\hline West Valley & & 522 & 6,390 & 4,720 & 4,700 & 4,950 & 4,510 & 4,280 & 5,098 & 6,370 & 7,057 & 7,500 & 8,580 & 2,049 & $0^{(a)}$ & $o^{(a)}$ & 66,726 \\
\hline Richlond & & & & 569 & 2.403 & 870 & 669 & 438 & 423 & 584 & 654 & 1,033 & 1,410 & 1,500 & 2,867 & 2,718 & 16,238 \\
\hline Sheffield & & & & & & 2,530 & 2,710 & 2,010 & 2,830 & 4,430 & 5,960 & B,530 & 12,400 & 14,112 & 13,480 & 17,642 & 86,634 \\
\hline Barnwell & & & & & & & & & & 1,171 & 3,757 & 15,839 & 18,244 & 18,072 & 40,227 & 45,563 & 142,873 \\
\hline TOTAL & 1,860 & 6,240 & 13,100 & 13,130 & 16,190 & 19,380 & 19,650 & 21,410 & 24,980 & 29,350 & $\mathbf{3 7 , 3 3 0}$ & 47,080 & 53,250 & 57,010 & 74,220 & 71,360 & 505,541 \\
\hline
\end{tabular}

(a) West Valley closed March 1975

- Preliminary values obtained from private communication with each burial site. 

TABLE F-7

COMMERCIAL SITE SOURCE MATERIAL BURITAL HISTORY ${ }^{3,}$ 9-14 SITE SOURCE MATERIAL BURITAL
SOURCE MATERIAL BUPIED (kg)

\begin{tabular}{|c|c|c|c|c|c|c|c|c|c|c|c|c|c|c|c|c|c|}
\hline YEAR & 1962 & 1963 & 1964 & 1965 & 1966 & 1967 & 1968 & 1969 & 19.70 & 1971 & 1972 & 1973 & 1974 & 1975 & 1976 & 1977* & TOTAL \\
\hline Beatty & 296 & 472 & $33 \mathrm{t}$ & 236 & 91 & 346 & 1,040 & 290 & 322 & NA & 9,340 & 11,500 & 9,710 & 1,438 & 5,000 & 22,175 & $62,58 \%$ \\
\hline Morehead & & 5,210 & 5,590 & 568 & 690 & 5,680 & 6,250 & 2,550 & 7,220 & 5,730 & 8.260 & 9,340 & 13.100 & 82,416 & 75,949 & 655 & 229,203 \\
\hline West Valley & & 7.580 & 10,100 & 22,200 & 38,300 & 20,300 & 6,460 & 80,000 & 31,700 & 51,400 & 72,500 & 44,200 & 61,700 & $N A^{(a)}$ & $a^{(a)}$ & $0^{(0)}$ & 446,440 \\
\hline Richland & & & & 0.9 & 253 & 0.9 & 2.7 & 88.4 & 31.3 & 606 & $3,112.5$ & 2,250 & 20.3 & 215 & 5,011 & 2,753 & 14,345 \\
\hline Sheffield & & & & & & 3,930 & 8,703 & 6,330 & 2,000 & 212 & 3,600 & 2,410 & 13,900 & 35,950 & 3,854 & 216,000 & 296,889 \\
\hline Barnwell & & & & & & & & & & 12,546 & 1,606 & 45,305 & 26,961 & 46,005 & 24,367 & NA & $154,790^{(b)}$ \\
\hline
\end{tabular}

\section{TOTAL}

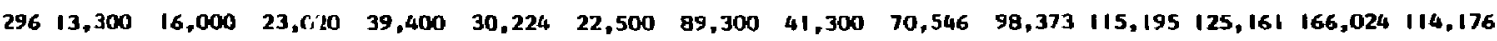

* Non-fissile uranium and thorium

(o) West Valley was closed March 1975

(b) Through 1976

MA Not available

- Preliminary values obrained from private communication with each burial site. 
One difficulty encountered in analysis of existing commercial site inventories arises from the past use of terms like "by-product material" and "mixed fission product" rather than identifying specific radionuclide contents of buried wastes.

A second difficulty involves the variation in values from independent inventories at each site. There are several causes, including the lack of specific radionuclide information as discussed above, and differing interpretations of those unspecific data. In addition, the values for radionuclide content of the buried wastes have been determined largely by estimates provided by the waste generator. 


\subsection{INSTITUTIONAL ASPECIS}

Handling and burial of solid radionctive waste by the privote sector is regulated in several ways. At the national level, the Nuclear Regulatory Commission (NRC) has responsibility for licensing waste burial sites except where its authority has been relinquished to "Agreement States." The ownership and licensing of commercial sites is summarized in Table F-8. Illinois, the only nonagreement state with a commercial radwaste burial site is presently in the process of negotiating such an agreement. The NRC also licenses the handling and burial of special nuclear materials at the commercial sites in Nevada and Washington, as the quantities of these materiols handled are greater than permitted under "Agreement State" provisions.

The license for operation of a burial site continuously undergoes modification. 2,8 This results from special petitions from the site operator to the regulating agency requesting authority to handle waste forms or quantities not previously encountered. As a result, the license is in effect an accumulation of correspondence betwetn the site operator and the vorious regulating agencies which may occupy more than a meter of shelf space. Licenses are issued for a fixed time period, at the end of which the operator must reopply. The license is automatically extended during the application review period.

The renewal procedure is greatly complicated by the complexity of the license and its amendments, and by continually changing state and Federal regulations. For example, several states have restricted the burial of plutonium (TRU) in concentrations greater than $10 \mathrm{nCi} / \mathrm{g}$ of waste. This restriction resulted primarily from a similar restriction imposed by DOE on its own burial site operators. A proposed 10 CFR 20 rule cinange would prohibit all shallow land burial of wastes containing more than a specific level of transuranic nuclides. Such waste would be transferred to Federal custody for ultimate disposal. The present non-uniformity of reglations, and pending changes in those regulations produces considerable difficulty in the license renewal. 



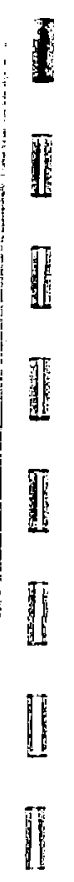

APPENDIX G

DOEFACILITY SURVEY

QUESTIONNAIRE AND RESULTS

TERACORPORATION 
䧏

]

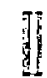

1

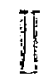

\section{APPENDIX H}

\section{POTENTIAL TRU WASTE SOURCES}

1

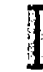

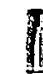

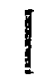

$\Gamma$

\lceil

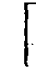

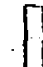


I

[ [ contaminated waste (TRU levels above $0 \mathrm{nCi} / \mathrm{g}$ ).

I

[

I

[

[

l

This Appendix will list all NRC holders of SNM licenses who might generate TRU

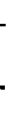

I

I<smiles>[CH]</smiles>

L

[

$\Gamma$

[

${ }_{H-1} \cdot$

TERI CORPORATON 